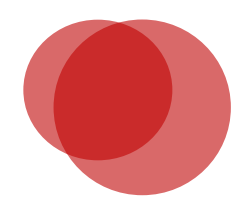

\title{
Estudo
}

\section{Posicionamentos das Entidades Artísticas No Âmbito da Revisão do Modelo de Apoio às Artes}

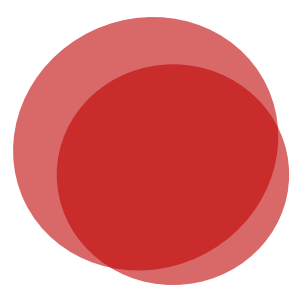

José Soares Neves (coord.) Joana Azevedo Rui Telmo Gomes

Maria João Lima 



\section{FICHA TÉCNICA}

Título: Estudo Posicionamentos das Entidades Artísticas no Âmbito da Revisão do Modelo de Apoio às Artes

Autoria: José Soares Neves (coord.) (ISCTE-IUL, CIES-IUL), Joana Azevedo (ISCTE-IUL, CIES-IUL), Rui Telmo Gomes (ISCTE-IUL, CIES-IUL) e Maria João Lima (ISCTE-IUL, CIES-IUL)

Enquadramento institucional: Instituto Universitário de Lisboa (ISCTE-IUL), Centro de Investigação e Estudos de Sociologia (CIES-IUL)

Revisão de texto: Ana Valentim Dias

Conceção gráfica e paginação: Sofia Rocha

Impressão e acabamentos: Europress, Ld. a

Depósito legal: 439245/18

Financiamento: República Portuguesa - Cultura / Direção-Geral das Artes

Ajuste Direto Procedimento Ref.a 0.02/DSGFP/2017

Para acesso à versão digital: $\underline{\text { http://hdl.handle.net/10071/14962 }}$

DOI: $10.15847 /$ CIESIUL/2017/ESTUDO

ISBN: 978-989-8518-02-6

ISBN: 978-972-8048-20-4

DIREÇÃO-GERAL DAS ARTES CIES-IUL Centro de Investigação e Es-

Campo Grande 83 - 1.

1700-088 Lisboa

comunicacao@dgartes.pt tudos de Sociologia - Instituto Universitário de Lisboa Avenida das Forças Armadas Edifício Sedas Nunes, Sala 2W10 1649-026 Lisboa cies@iscte-iul.pt

Data: dezembro de 2017

Tiragem: 500 exemplares 



\section{ÍNDICE}

ÍNDICE DE GRÁFICOS, QUADROS E TABELAS ............................................... vii

AGRADECIMENTOS

PREFÁCIO

Secretário de Estado da Cultura, Miguel Honrado............................................2

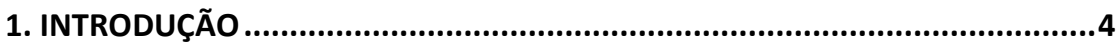

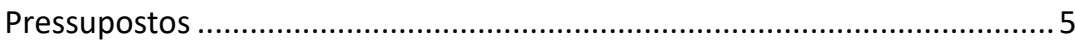

Enquadramento e antecedentes no sistema de apoio

financeiro às artes em Portugal ............................................................... 9

Processos anteriores de auscultação ........................................................... 10

Os apoios e as entidades: indicadores do MAA .......................................... 11

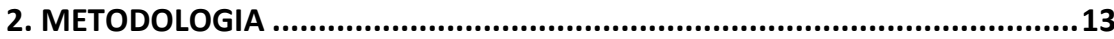

3. TRABALHO DE TERRENO E COMUNICAÇÃO ............................................15

Participação alargada das entidades artísticas ........................................... 15

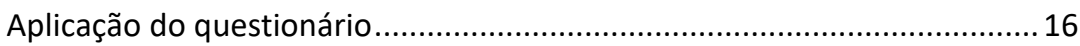

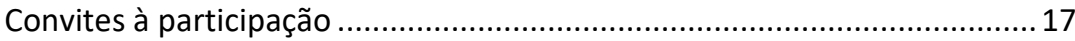

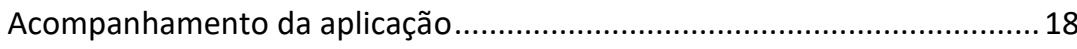

Da listagem final de entidades inscritas na plataforma eletrónica da

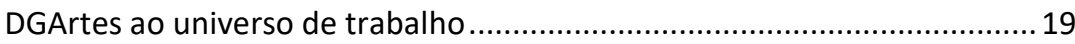

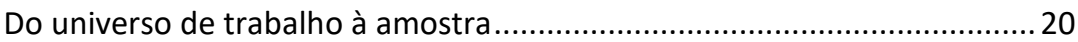

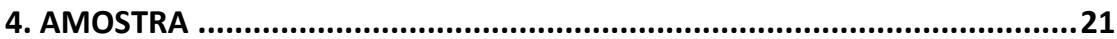

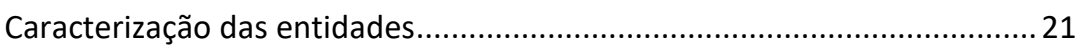

O historial de apoios das entidades que compõem a amostra .......................31

Motivos invocados pelas entidades para nunca terem concorrido aos apoios 
Modalidades de concurso por tipologia de atividade

(criação/programação) ................................................................................ 44

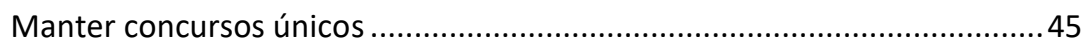

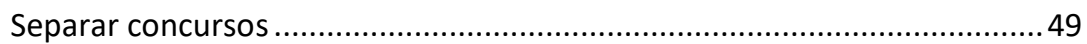

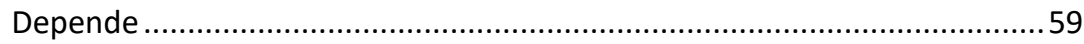

Áreas artísticas objeto de apoio..........................................................63 63

Manter os apoios às atuais áreas artísticas..................................................65

Restringir as áreas artísticas apoiadas .................................................. 70

Alargar os apoios a outras áreas artísticas ........................................... 73

Distribuição das despesas a considerar nos apoios .................................. 82

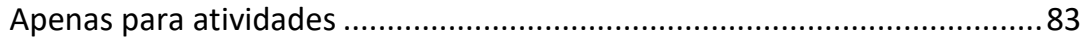

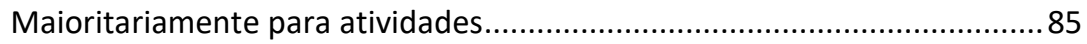

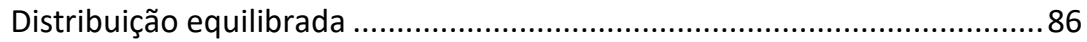

Distribuição privilegiando a estrutura....................................................90

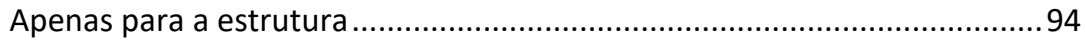

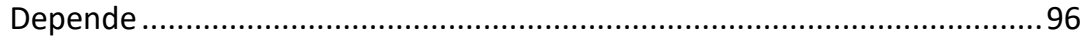

Mecanismos de atribuição de apoios .................................................. 104

Relação entre a entidade e a DGArtes ............................................... 113

Relação com os serviços da DGArtes .................................................... 114

Resposta por parte dos serviços da DGArtes ........................................ 119

Relação futura com a DGArtes .............................................................121

Processo administrativo e plataforma eletrónica.................................... 127

Divulgação: calendário, abertura de concurso e resultados .....................127

Apoio à instrução da candidatura .........................................................128

Plataforma: instrução da candidatura................................................... 129 
Valorização do projeto artístico ..............................................................130

Simplificação do processo de candidatura.................................................131

Historial e documentação relativa à entidade .............................................133

Documentação de entidades parceiras......................................................134

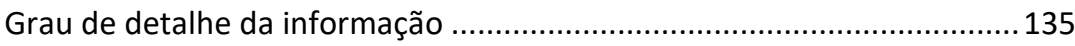

Orçamento, agenda e propostas de novas funcionalidades .......................137

Adequação da estrutura de candidatura às especificidades da entidade.. 140

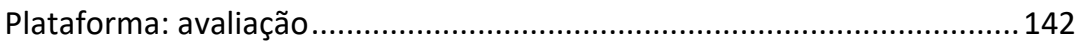

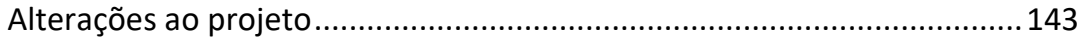

Correspondência da plataforma com os critérios de avaliação ....................145

Comissões de apreciação ..........................................................................145

Composição e perfil das comissões de apreciação ....................................146

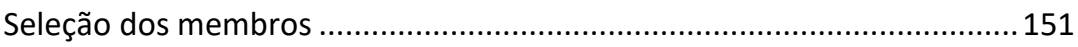

Divulgação prévia da comissão de apreciação ...........................................152

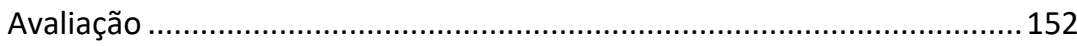

Comissões de acompanhamento e avaliação ..............................................156

Relação entre a entidade e as direções regionais de cultura .........................165

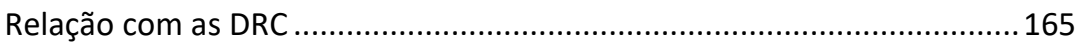

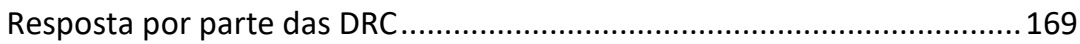

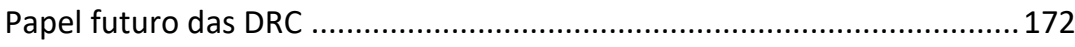

Articulação entre administração central e local ..........................................176

Relação entre autarquias e entidades artísticas .........................................177

Relação entre administração central e local ................................................... 181

Separação de funções entre níveis administrativos.................................... 181

Complementaridade de funções entre níveis administrativos ....................182

Articulação coordenada pela tutela da cultura ............................................ 184

Desresponsabilização da administração central ........................................ 185 


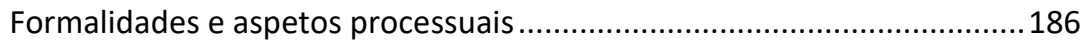

Circulação das produções artísticas ....................................................... 187

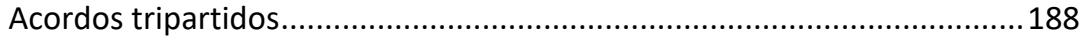

Redes de programação ...................................................................... 193

Representações da noção de rede ........................................................ 194

Processos de funcionamento .............................................................. 198

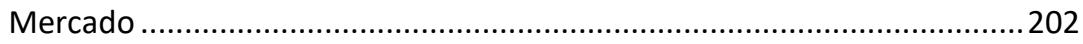

Internacionalização..................................................................... 205

Circulação de projetos...........................................................................208

Residências .................................................................................. 211

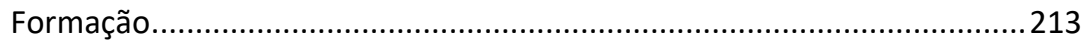

Plataformas e convite a programadores/curadores ................................2214

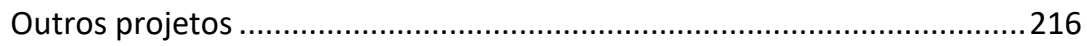

Posicionamento da DGArtes quanto a projetos internacionais em rede...218

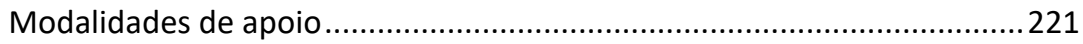

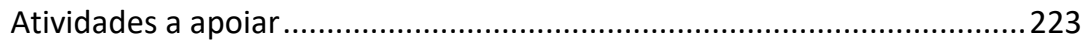

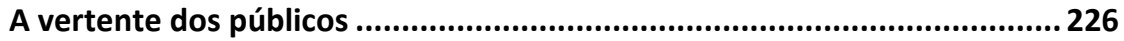

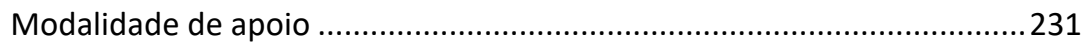

Majoração em candidatura ....................................................................235

Critério de avaliação...............................................................................240

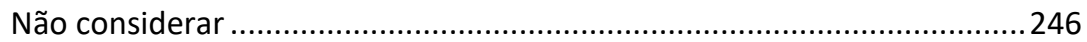

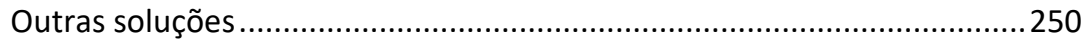

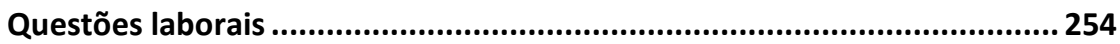

Propostas no âmbito do Modelo de Apoio às Artes ...................................254

Propostas fora do Modelo de Apoio às Artes ........................................259 


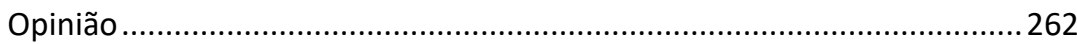

Objetivos e procedimentos administrativos ......................................... 265

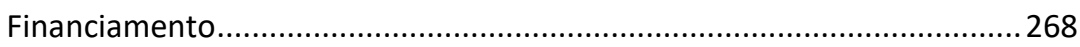

Medidas e programas específicos ......................................................... 270

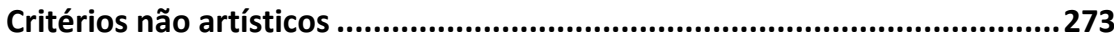

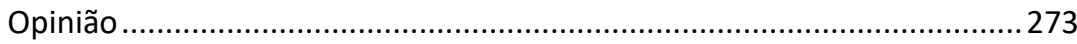

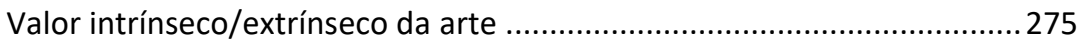

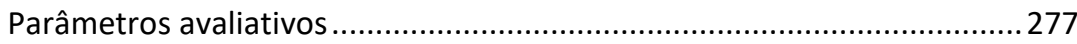

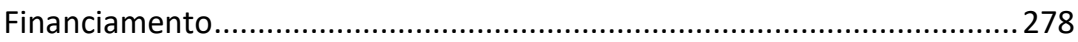

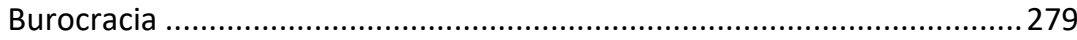

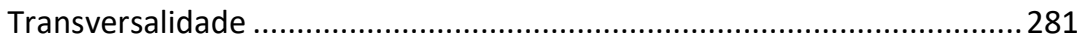

A avaliação do regulamento de apoio às artes .........................................283

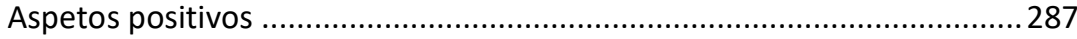

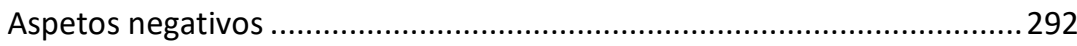

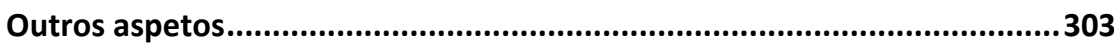

Os teatros e cineteatros, os programas de redes de equipamentos de artes do espetáculo de parcerias central/locais .............................................304

Sobre o Estudo Posicionamentos das Entidades Artísticas ....................... 304

Programas e linhas a apoiar/considerar ............................................. 310

Novas entidades e estruturas estabelecidas............................................ 312

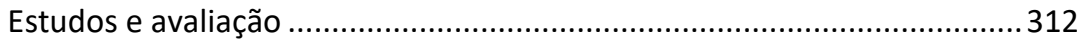

Acompanhamento e avaliação dos contratos .......................................... 313

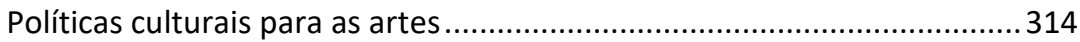

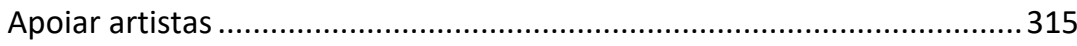

Outras fontes de financiamento ......................................................... 317

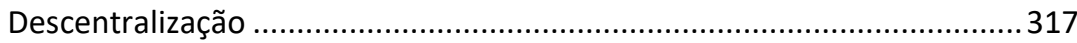




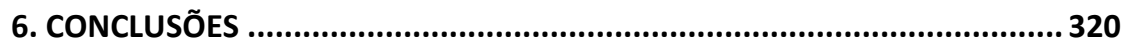

Sugestões das entidades artísticas..........................................................330

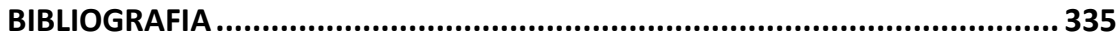

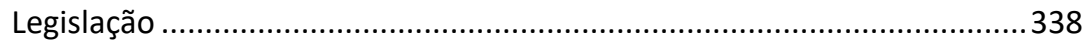

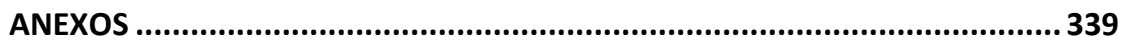

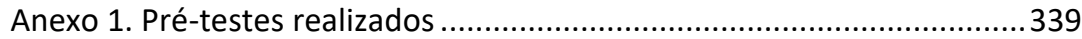

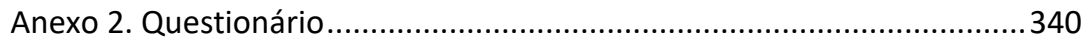

Anexo 3. Modelo de e-mail: convite à participação..................................352

Anexo 4. Modelo de e-mail: lembrete …................................................354

Anexo 5. Taxa de resposta às perguntas abertas (parte ii - contributos) .. 355

Anexo 6. Intervenção do Secretário de Estado da Cultura, Miguel Honrado, nas sessões regionais de apresentação da proposta de modelo de apoio às artes

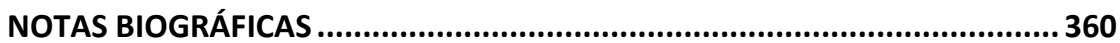




\section{ÍNDICE DE GRÁFICOS, QUADROS E TABELAS}

\section{ÍNDICE DE GRÁFICOS}

Gráfico 1. Montantes do apoio às artes (2009-2016).................................. 12

Gráfico 2. Cronograma do trabalho de terreno........................................... 17

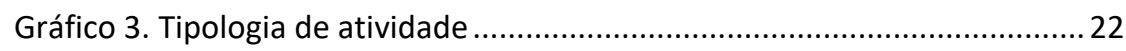

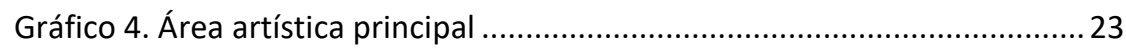

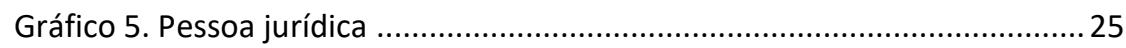

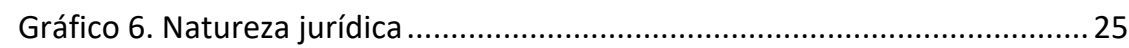

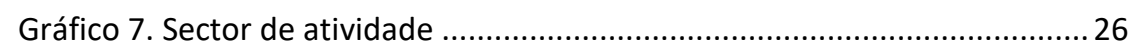

Gráfico 8. Região onde está localizada a sede da entidade ...........................227

Gráfico 9. Data de fundação/início de atividade profissional (escalões).......... 28

Gráfico 10. Data de fundação/início de atividade profissional ........................ 29

Gráfico 11. Orçamento das entidades em 2016 ........................................... 31

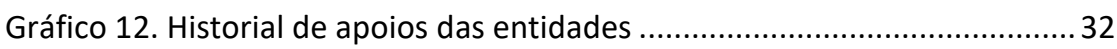

Gráfico 13. Área artística principal por relação com o historial de apoios da

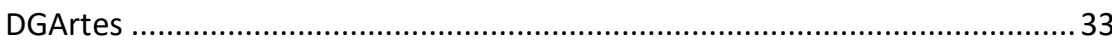

Gráfico 14. Modalidades de apoio de que beneficiaram as entidades que tiveram apoio e a que se candidataram entidades que nunca tiveram apoio . 34

Gráfico 15. Áreas artísticas objeto de apoio....................................................63

Gráfico 16. Distribuição dos apoios entre atividades e estrutura .................... 82

Gráfico 17. Projetos de internacionalização a contemplar nos apoios .......... 206

Gráfico 18. Públicos no modelo de apoio às artes .....................................2231 


\section{ÍNDICE DE QUADROS}

Quadro 1. Da listagem inicial à listagem final de entidades registadas 16

Quadro 2. Acompanhamento do questionário: mensagens recebidas por e-mail .18

Quadro 3. Da listagem final ao universo de trabalho 19

Quadro 4. Participação no estudo 20

Quadro 5. Entidades com candidatura .24

Quadro 6. A amostra segundo o historial de apoios .35

Quadro 7. Alargamento do apoio a outras áreas artísticas por domínio cultural. .73

Quadro 8. Outros eixos de apoio sugeridos pelas entidades .80

\section{ÍNDICE DE TABELAS}

Tabela 1. Dimensões de análise do estudo. 6

Tabela 2. Aspetos positivos e negativos do regulamento de apoio às artes .. 284 


\section{AGRADECIMENTOS}

A equipa de investigação do Centro de Investigação e Estudos de Sociologia (CIES-IUL) do Instituto Universitário de Lisboa (ISCTE-IUL) gostaria de expressar o seu agradecimento a um conjunto de pessoas e entidades que tornaram este estudo possível. Ao Senhor Secretário de Estado da Cultura, Miguel Honrado, à Diretora-Geral das Artes, Paula Varanda, e respetivas equipas, pela iniciativa de promover este estudo e pelo empenho dedicado à sua concretização. À Direção-Geral das Artes (DGArtes) agradecemos o apoio financeiro e técnico indispensável à realização do estudo. O nosso agradecimento estende-se também às Direções Regionais de Cultura pelo apoio na divulgação do estudo, nomeadamente nas sessões públicas de apresentação junto das entidades artísticas no território.

Queremos também deixar o nosso agradecimento ao Centro de Investigação e Estudos de Sociologia (CIES-IUL) e ao Instituto Universitário de Lisboa (ISCTE-IUL) pelas condições proporcionadas à equipa e pelo apoio técnico e científico assegurado ao desenvolvimento do estudo.

Agradecemos muito em particular a todas as entidades artísticas e respetivos representantes que empenhada e generosamente se disponibilizaram a participar no estudo, algumas delas também no pré-teste do questionário, cujos contributos foram essenciais para identificar os diversos posicionamentos do sector face às políticas e ao modelo de apoio às artes em Portugal.

José Soares Neves (coord.)

Joana Azevedo

Rui Telmo Gomes

Maria João Lima 


\section{PREFÁCIO}

O desafio de criar políticas estruturantes para o sector das artes, proposto pelo Ministério da Cultura do XXI Governo da República Portuguesa, exigiu a criação de um plano de trabalho, em diferentes frentes e em diversas fases, assente na participação de todos os agentes que, de forma direta ou indireta, têm responsabilidades no desenvolvimento das políticas e das atividades culturais do país. Até 1998 não existia a figura legislada de um concurso para atribuir os apoios públicos às artes. O financiamento às entidades e a projetos artísticos era, assim, uma decisão iminentemente política. Foi criado, à época, um modelo de apoios e o respetivo enquadramento legal que regulou o sector ao longo dos últimos vinte anos.

O sistema então criado, e consecutivos ajustes introduzidos ao longo desse tempo, imprimiu uma política de maior transparência ao sector e também introduziu regras concorrenciais aos agentes culturais profissionais. Esse grande passo de regulação e regulamentação foi imprescindível para o crescimento sustentado e para a qualificação das artes em Portugal.

Aqui chegados, sabíamos empiricamente que o modelo de apoio às artes vigente não era contemporâneo das exigências e necessidades de uma área que cresceu e se desmultiplicou em diferentes contextos da criação e da programação. Também não conseguia responder aos desafios da atualidade cultural do país, nem às ambições das políticas culturais do futuro.

Alterar uma ferramenta que modelou a criação e a programação artísticas em Portugal surgia como decisão incontornável e apresentava-se como o desafio de uma legislatura.

A Secretaria de Estado da Cultura e a Direção-Geral das Artes iniciaram um processo que visava alterações estruturantes nos modelos de apoios públicos às artes.

$\mathrm{O}$ projeto tinha algumas premissas. Criar um processo de trabalho participado, que envolvesse todos aqueles que pudessem ter uma palavra a acrescentar, para que o resultado fosse o mais rigoroso e ajustado às várias realidades artísticas, geográficas, logísticas, sociais, económicas e políticas. Assim, Estado, poder central e local, entidades culturais e organizações públicas e sociedade civil reuniram-se em torno de um projeto e de uma ambição de futuro.

Este estudo é o resultado desse diálogo e de uma visão partilhada entre Estado, agentes culturais e sociedade civil. 
Partir para a construção de uma ferramenta que operacionalizasse uma visão conjunta convidava a uma análise mais profunda da realidade e da experiência artística em Portugal.

Com o objetivo de produzir conhecimento e reflexão sobre as atividades e práticas culturais e artísticas em Portugal, tomámos a decisão de integrar uma equipa profissional que nos ajudou a sistematizar o volume de informação de que necessitávamos, para podermos decidir, com responsabilidade, sobre as características e o alcance de um novo modelo de apoio às artes.

Queríamos um processo de auscultação ao sector alicerçado numa metodologia científica e dialogante, que promovesse a liberdade de opinião e a igualdade de oportunidades na participação. Queríamos conhecer em profundidade todas as necessidades e expectativas dos vários atores culturais do país. Queríamos ouvir o estado da arte na primeira pessoa e pretendíamos debater e receber ideias, sugestões e críticas. Queríamos ouvir todos os agentes culturais do país. Tudo em prol de um objetivo maior, que todos queríamos construir.

A resposta foi inquestionavelmente positiva e as informações reveladas foram essenciais às tomadas de decisão e legislação que se seguiram.

A missão a que todos nos propusemos é o que aqui compilamos. Esta publicação é a voz dos agentes culturais do país no ano de 2017.

O novo modelo de apoio às artes, entretanto já em vigor, foi o resultado de um longo curso de investigação, experimentação e maturação de soluções. Foi um processo de audição atenta e cruzada, de múltiplos fatores que se completavam, e de transposição em decisões; foi, em suma, um exercício de compreensão e de aprendizagem em prol de um bem comum.

Uma nova abordagem na articulação, cooperação e interseção entre Estado e agentes culturais foi, sem dúvida, o fator crítico de sucesso deste projeto.

Quando assim é, torna-se efetivamente possível criar novas condições no sentido de desenvolver mais e melhores políticas culturais para o país.

O Ministério da Cultura agradece a todos aqueles que tornaram este estudo uma realidade.

Secretário de Estado da Cultura

Miguel Honrado

29 de dezembro de 2017 


\section{INTRODUÇÃO}

Que posicionamentos se podem identificar sobre o modelo de apoio às artes? É a esta pergunta que o presente Estudo Posicionamentos das Entidades Artísticas no Âmbito da Revisão do Modelo de Apoio às Artes (abreviadamente EPEA), promovido pela DGArtes e pela tutela para auscultação das entidades artísticas sobre o Modelo de Apoio às Artes (MAA), no âmbito da redefinição prevista no programa do XXI Governo Constitucional, pretende responder. $\mathrm{O}$ estudo decorreu entre janeiro e junho de 2017, num total de cinco meses. ${ }^{1}$

Nesta introdução começa-se por enunciar o conjunto dos pressupostos que suportam o estudo. Faz-se depois o enquadramento no sistema de apoio financeiro às artes em Portugal, referem-se anteriores processos de auscultação ao sector e os indicadores disponíveis sobre os apoios e as entidades candidatas e beneficiárias. No primeiro capítulo faz-se referência à estratégia metodológica seguida, com destaque para a delimitação do universo de trabalho e para o instrumento de recolha de informação (inquérito qualitativo por questionário online). Faz-se depois o balanço do trabalho de terreno e da recolha de contributos que decorreu entre 14 de fevereiro e 3 de março de 2017. A caracterização das entidades que participaram no estudo e que constituem a amostra é feita no terceiro capítulo a partir de um conjunto de questões incluídas no inquérito com esse objetivo. Segue-se o capítulo central do estudo totalmente preenchido com a análise dos posicionamentos sobre as diversas dimensões que foram objeto do inquérito. De acordo com o carácter qualitativo dos contributos recolhidos, e que estão na base da análise, as várias dimensões são aqui ilustradas com citações diretas das respostas. Em geral opta-se por reproduzi-las integralmente. $^{2}$

\footnotetext{
${ }^{1}$ Uma síntese dos resultados, com destaque para as sugestões das entidades, foi apresentada em reuniões regionais com entidades em que estiveram presentes o secretário de Estado da Cultura - ver intervenção no anexo 6 - e a diretora-geral das Artes, para além do coordenador científico do estudo (Neves, Azevedo, Gomes e Lima, 2017). Uma outra apresentação, sobre metodologia e resultados, foi feita no ISCTE-IUL no âmbito dos workshops de investigação do CIES-IUL (Neves, Azevedo, Gomes e Lima, 2017a).

${ }^{2}$ Note-se a este propósito que embora o corpo do relatório adote o Novo Acordo Ortográfico, as citações das respostas das entidades são reproduzidas tal qual foram expressas.
} 
A concluir sintetizam-se as principais linhas decorrentes do estudo, bem como as sugestões que dele emergem e que visam informar a revisão do modelo nas suas diversas vertentes.

Nos anexos podem ser consultados o questionário, os suportes de comunicação da equipa do estudo no CIES-IUL com as entidades e as taxas de resposta totais às questões abertas que suscitaram os contributos das entidades. As questões e as taxas de resposta são também referidas à medida que se procede à análise das respostas.

\section{Pressupostos}

São vários os pressupostos que estão na base da realização do estudo e dos resultados que aqui se apresentam. O primeiro pressuposto é que o apoio público a entidades artísticas privadas não lucrativas, no sentido da prestação de um serviço público, é um mecanismo de política cultural generalizado nos países ocidentais desde o pós-guerra (Zimmer e Toepler, 1999: 33). A necessidade do apoio público às artes como garante da sua permanência e diversidade está largamente demonstrada e tem sido posta em prática seja no modelo direto (no qual Portugal se inclui), seja no indireto (adotado nos EUA e no Reino Unido, entre outros) (Throsby, 2010: 73). É um mecanismo com um largo espectro temporal no Portugal democrático, com um enquadramento legal mais definido a partir do início dos anos noventa ${ }^{3}$ (XI Governo Constitucional, PSD), então dirigido ao teatro e que foi sucessivamente alargado até ao modelo aqui em análise que abrange diversas áreas artísticas, e que aliás não se restringem às normalmente consideradas no sector artístico e cultural, mas que inclui também áreas (como a arquitetura e o design) que se inserem no que se vem designando como sector cultural e criativo (AAVV, 2006). Não se trata, pois, de um estudo sobre modelos de apoio do Estado às artes (Lacombe, 2004; Alexander, 2014: 8), mas sim sobre um determinado modelo de apoio, aquele em vigor em Portugal desde 2006, ou seja, de acordo com as dimensões de análise do estudo (ver tabela 1), sobre políticas públicas, política cultural (e a articulação entre políticas culturais centrais e desconcentradas, por um lado, e entre aquelas e as políticas locais, por outro, incluindo os objetivos e os meios disponibilizados para

\footnotetext{
${ }^{3}$ Sobre as posições político-partidárias em torno dos "subsídios" e as práticas dos vários governos constitucionais nesta matéria até 2003, ver José Soares Neves em AAVV (2002: 91); sobre a regulamentação dos apoios ao teatro nos anos noventa e as polémicas que em torno dela se geraram ver capítulo "Teatro" em Santos et al. (1998: 177-191).
} 
os concretizar), as normas que o regulamentam, o enquadramento orgânico que o coordena e executa, as disposições em que se baseiam, os instrumentos utilizados e os procedimentos que lhe são inerentes - de candidatura, de avaliação e de acompanhamento. E em que se inclui ainda a produção e difusão de conhecimento suscetível de informar as políticas, o modelo de apoio e o sector como um todo.

Tabela 1. Dimensões de análise do estudo

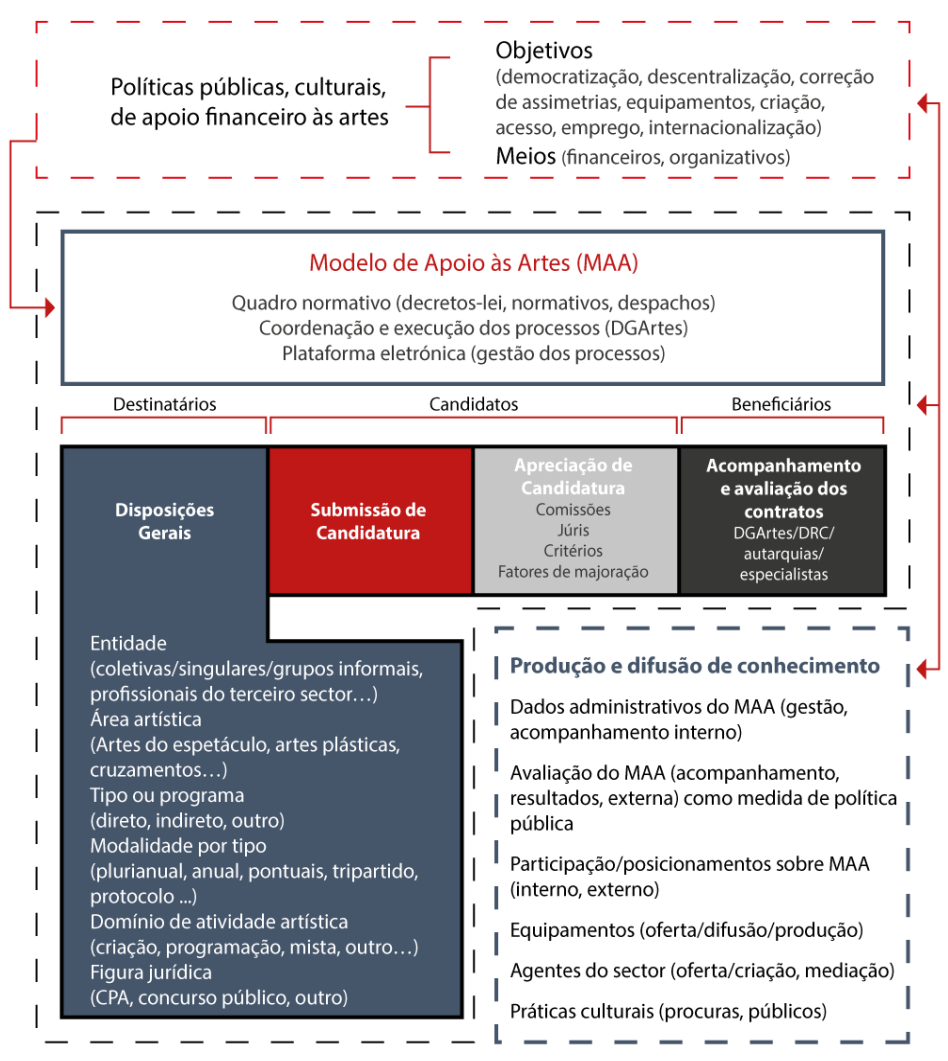

Trata-se, segundo pressuposto, de um estudo sobre um mecanismo de política pública com enormes implicações em múltiplas vertentes. Entre elas destacam-se desde logo as que se referem ao conjunto do tecido artístico nacional, à atividade das entidades das diversas áreas artísticas e dos profissionais nelas envolvidos, num contexto de mercado assistido (Ferreira et al., 2016: 3); implicações também na democratização e no acesso da generalidade da população 
às manifestações artísticas por via da diversificação, descentralização e correção das assimetrias regionais da oferta cultural. Como medida de política pública decorrem impactos vários dos programas e dos orçamentos da cultura e é, portanto, vulnerável às suas oscilações, seja quanto às orientações e prioridades políticas, seja quanto aos montantes a elas afetados, sem esquecer fatores de contexto como os ciclos económicos e em particular o de crise financeira e económica como o que se manifestou em Portugal nos anos recentes.

O MAA é uma medida de política pública cuja execução está atribuída à DGArtes e cujo enquadramento legal aplicável remonta a 2006. A permanência deste enquadramento, como a sua alteração, depende, naturalmente, dos objetivos políticos. A opção do XXI Governo Constitucional, definida no programa e reafirmada em diversos outros documentos (ministro da Cultura, 2016: 7-8), vai no sentido da revisão, opção que é acompanhada pela intenção de que seja um processo participado, com auscultação do sector. Auscultação com vista a informar a revisão do modelo que se concretizou por parte da DGArtes em vários momentos e de diversos modos (designadamente reuniões parcelares, recolha de contributos escritos). O presente estudo, que foi apresentado publicamente entre 7 e 10 de fevereiro de 2017 em cinco sessões realizadas com entidades artísticas nas cinco regiões do Continente com o secretário de Estado da Cultura e com a diretora-geral das Artes, insere-se neste processo de que constitui um dos modos, justamente aquele que tem por objetivo possibilitar a recolha de contributos da generalidade ${ }^{4}$ das entidades artísticas. Este é o terceiro pressuposto.

A concretização do referido objetivo pressupõe que as entidades inquiridas e os contributos recolhidos se situam preferencialmente no quadro de referência constituído pelo modelo em análise e decorrem da experiência das entidades na sua relação - mais prolongada ou mais recente, mais intensa ou mais esporádica, mais próxima ou mais distante, como entidades coletivas ou singulares, como beneficiárias, candidatas, elegíveis ou meramente interessadas com o modelo de apoio financeiro gerido pela DGArtes, o que significa, em todo o caso, alguma proximidade com os instrumentos que desde 2006 o regulamentaram e que suportaram todo o processo administrativo. Este é, portanto, o quarto pressuposto que importa referir.

\footnotetext{
${ }^{4} \mathrm{~A}$ propósito de processos participativos em organismos da cultura em Portugal, haverá que referir o Plano Estratégico da DGPC 2015-2019 (Camacho et al., 2015), pelos vários modos de auscultação utilizados, incluindo um inquérito em plataforma online dirigido ao universo que esteve na base da construção do plano, nesse caso os funcionários da DGPC - Direção-Geral do Património Cultural.
} 
A complexidade do modelo e o objetivo do estudo determinaram a utilização de um método extensivo de recolha de informação (o inquérito online) mas com uma componente qualitativa dominante, ou seja, de perguntas de resposta aberta ao preenchimento pela entidade. Tendo em conta que se trata do processo de revisão do modelo - e não apenas de uma ou várias componentes -, optou-se por considerar no questionário um conjunto alargado de dimensões sobre as quais se procurou obter os contributos das entidades. Assim, embora tendo presente a fronteira, nem sempre fácil de estabelecer, entre um olhar avaliativo e um outro prospetivo, procurou-se identificar posicionamentos preferencialmente nesta segunda ótica (o que deverá ser feito?) e não tanto na avaliativa (o que correu bem, o que correu mal?). Este é o quinto pressuposto: em último caso, o presente estudo pretende suscitar contributos e a partir dos posicionamentos deles decorrentes identificar possíveis vias quanto a alterações a introduzir no sistema de apoio às artes ${ }^{5}$.

Por isso, uma perspetiva predominantemente avaliativa esteve desde sempre fora do horizonte do estudo, sexto pressuposto. Este estudo visa recolher informação sobre os posicionamentos das entidades numa fase de mudança no Modelo de Apoio às Artes, não pretende responder às várias necessidades de informação que se podem colocar ao conjunto dos agentes do sector. Mesmo quanto à recolha de contributos das entidades envolvidas, constitui tão só uma das vias, uma vez que a auscultação promovida pela DGArtes incluiu, como antes se referiu, vários modos. Mas tem a preocupação de identificar também as necessidades que se colocam a este nível (ver tabela 1, dimensões do modelo de análise). De resto são sobejamente conhecidas as lacunas na produção de informação sistematizada sobre o sector cultural em Portugal, designadamente de base territorial, de apoio à tomada de decisão dos organismos da administração central (Figueiredo e Babo, 2015: 244-245), lacunas portanto de conhecimento em diversos planos, em particular quanto: às práticas culturais da população portuguesa; aos recintos culturais dos domínios culturais aqui mais em foco, muito especialmente aqueles que foram construídos ou requalificados no quadro de programas de redes que articularam as administrações central e local; aos agentes dos mundos artísticos (os artistas mas necessariamente também os técnicos, os programadores, produtores, etc.); ao acompanhamento e

\footnotetext{
5 Os instrumentos legais que corporizam o novo modelo foram, entretanto, publicados: Decreto-Lei n.o 103/2017, de 24 de agosto (regime de atribuição de apoios financeiros do Estado); Portaria n.o 301/2017, de 16 de outubro (regulamento dos programas de apoio às artes); Portaria n. 302/2017, de 16 de outubro (regulamento da composição e funcionamento das comissões de apreciação e das comissões de avaliação).
} 
avaliação de medidas de política cultural, como a aqui em análise, de apoio às artes. Lacunas a que se acrescenta a escassez de estudos sobre os públicos, espetadores, comunidades ou participantes.

A estratégia expositiva dos resultados obtidos a partir dos contributos qualitativos inclui: a) uma leitura global das principais temáticas que a análise de conteúdo revela, identificando as tendências que emergem dos posicionamentos e eventuais polarizações, bem como os matizes que se perfilam; b) citações diretas, em geral integrais, dos contributos das entidades suscetíveis de melhor ilustrar as temáticas em causa.

A este último propósito há que valorizar a adesão ao estudo com o elevado número de entidades participantes e a vastidão dos contributos recolhidos (confidenciais e anónimos no relatório, condições que, juntamente com o facto de o estudo estar a ser conduzido por um centro de investigação exterior à tutela, foram cruciais para o nível de adesão alcançado), pelo que se procura dar conta da riqueza e diversidade dos contributos em várias dimensões com recurso a um elevado número de citações. Espera-se, deste modo, contribuir para o objetivo central do estudo - informar a revisão do MAA e a construção de um novo modelo de apoio às artes - e para um outro que, embora não enunciado formalmente, é igualmente importante e é mesmo inerente a um estudo de um processo participativo como este, ou seja, contribuir para o debate mais informado entre os agentes do sector. Este é, assim, o sétimo e último pressuposto.

\section{Enquadramento e antecedentes no sistema de apoio financeiro às artes em Portugal}

Para além dos pressupostos atrás referidos, na realização do estudo teve-se em conta, por um lado, a genealogia do atual regime jurídico e, por outro, um conjunto de abordagens antes realizadas sobre ou com relevância para a análise do MAA.

O regime jurídico do modelo atual é conformado pela legislação de 2006 com as alterações introduzidas em 2008 e em $2012^{6}$. Uma rápida digressão pela

\footnotetext{
${ }^{6}$ A legislação principal que enquadra o MAA inclui o Decreto-Lei n. $.225 / 2006$, de 13 de novembro, e o Decreto-Lei n.o 196/2008, de 6 de outubro, e o Anexo à Portaria n.으 $58 / 2012$, de 13 de março (este especificamente quanto à internacionalização das artes). A DGArtes acumula as atribuições no domínio do apoio às artes (na vertente não profissional) da anterior Direção Regional de Cultura de Lisboa e Vale do Tejo (Decreto-Lei n.o 114/2012, de 25 de maio).
} 
produção legislativa mostra que o regime de apoio às artes, então apenas ao teatro ${ }^{7}$, tem em 1990, na vigência do XI Governo Constitucional (PPD/PSD), um importante momento. Contudo, as suas normas de apoio viriam a ser motivo de enorme polémica, em particular quanto ao peso dos quantitativos de espetadores na atribuição dos apoios (Santos et al., 1998: 177-187) e foram revogadas com a entrada em funções do governo socialista em 1995 (XIII Governo Constitucional) que promoveu não apenas essa revogação, mas também a produção de um vasto conjunto legislativo que, entre outros aspetos, estendeu os apoios a outras áreas das artes do espetáculo, como a dança e a música.

De qualquer modo, a polémica a que antes se aludiu não significa que a intervenção do Estado no apoio às artes em algum momento tenha estado em causa no Portugal democrático, tanto na prática estatal como nas posições dos partidos a este propósito, apesar das diferenças com uma importante margem de consenso (Neves, 2001). Aliás, apoios que diversos organismos da tutela da cultura, em diversos domínios artísticos e culturais, atribuíram (Santos et al., 2002; Santos, Neves e Santos, 2007) e atribuem.

O atual modelo decorre de uma crescente concentração da atribuição de apoios financeiros às entidades profissionais não estatais, não lucrativas, do terceiro sector, em parte decorrente das fusões de competências antes atribuídas a organismos com intervenção em diferentes domínios. Refira-se, por exemplo, os enquadramentos orgânicos dos domínios artes do espetáculo e artes visuais e outros: a fusão do IAC - Instituto de Arte Contemporânea e do IPAE - Instituto Português das Artes do Espectáculo no IA - Instituto das Artes, organismo a que passou a competir a atribuição de apoios nas artes do espetáculo e arte contemporânea (artes plásticas e visuais, incluindo arquitetura e design). E, mais recentemente, a DGArtes que sucedeu ao IA e ao CPC - Centro Português de Fotografia em matéria de apoio à difusão da fotografia e ao ICAM - Instituto do Cinema, Audiovisual e Multimédia quanto aos apoios ao multimédia ${ }^{8}$.

\section{Processos anteriores de auscultação}

O presente estudo insere-se, como foi já referido, num processo de auscultação do sector promovido pela DGArtes e pela tutela com vista à revisão do MAA, mas em que cumpre um objetivo específico - suscitar a recolha de contributos

\footnotetext{
7 Despacho Normativo n. 100/1990, de 14 de agosto.

${ }^{8}$ Respetivamente Decreto-Lei n.o 181/2003, de 16 de agosto (cria o IA), e Decreto-Lei n. $91 / 2007$, de 29 de março (funda a DGArtes).
} 
da generalidade das entidades interessadas, por definição aquelas inscritas na plataforma eletrónica de gestão dos apoios. Tem um antecedente próximo num inquérito de 2012 de "recolha de contributos aos agentes culturais" através de plataforma online ao qual responderam 69 entidades coletivas e singulares, apoiadas ou não pela DGArtes (DGArtes, 2013a). Embora tenha semelhanças com o EPEA, importa, contudo, notar que as diferenças são relevantes uma vez que se trata de um inquérito realizado noutro contexto, com questões diferentes e conduzido internamente ${ }^{9}$ na DGArtes. Ainda assim, quanto às conclusões, é visível a proximidade de vários dos argumentos então aduzidos com os que foram produzidos no presente estudo. Tal proximidade, verificada num lapso de quatro anos, parece querer significar que parte substancial das questões então consideradas relevantes não conheceu, entretanto, alterações significativas.

\section{Os apoios e as entidades: indicadores do MAA}

A DGArtes disponibiliza regularmente na sua página na internet informação dos serviços sobre os montantes atribuídos às entidades beneficiárias por modalidade de apoio ${ }^{10}$. Disponibiliza ainda documentos e estudos sobre os apoios, internos, externos ou em parceria ${ }^{11}$. No que se refere mais diretamente ao MAA importa referir o estudo ${ }^{12}$ sobre os apoios financeiros diretos (2009 e 2011) com base nos dados administrativos disponibilizados pela DGArtes e em estudos de caso (Santos e Moreira, 2013). Ainda a partir dos dados administrativos da DGArtes foram publicados relatórios trimestrais relativos a 2013 e $2014^{13} \mathrm{com}$

\footnotetext{
${ }^{9}$ Também conduzido internamente, mas aplicado por e-mail, refira-se o "Inquérito Online aos Participantes dos Workshops Realizados pela Direção-Geral das Artes - Avaliação da Utilidade dos Workshops" (DGArtes, 2013b).

10 https://www.dgartes.gov.pt, separador "Atividades, Apoio às Artes".

11 https://www.dgartes.gov.pt, separador "Sobre Nós, Estudos e Relatórios".

12 Para além dos estudos e relatórios referidos com indicadores do MAA ver ainda, entre outros, uma análise dos apoios ao teatro, incluindo apoio central pela DGArtes e desconcentrado pelas direções regionais de cultura (DRC), às "organizações culturais semiprofissionais, amadoras, recreativas e populares", ver Borges e Lima, 2014, e sobre estruturas e montantes dos apoios, entre outros indicadores, ver Garcia et al., 2014: 141. Num outro plano, o da avaliação dos impactos do PDAE - Programa Difusão das Artes do Espetáculo, programa do organismo que antecedeu a DGArtes, o IPAE, ativo entre 1999 e 2002, ver Santos et al., 2004.

${ }^{13}$ Seria muito útil que a publicação de relatórios com dados administrativos dos apoios fosse retomada.
} 
enfoques (internacionalização, acordos tripartidos, pegada cultural) e indicadores sobre várias dimensões, designadamente entidades beneficiárias, montantes dos apoios, atividades e respetivos públicos, os quais foram objeto de uma síntese para esse ano com comparação quanto aos montantes totais com os apoios (com 2012 e 2013), o número de apoios e os montantes por área artística (comparação com 2013) (Borges e Lima, s/ data).

Um indicador fundamental de enquadramento do presente estudo é a evolução do financiamento do MAA (gráfico 1).

Gráfico 1. Montantes do apoio às artes (2009-2016)

(em milhões de euros)

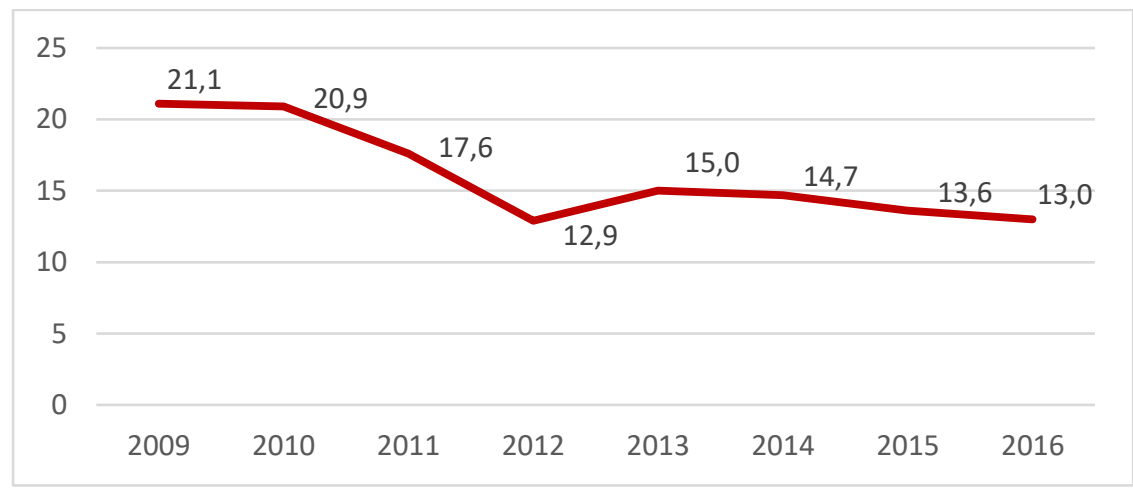

Fonte: DGArtes.

Os montantes anuais dos apoios às artes mostram que estes se situam em 2009 e 2010 num patamar acima dos 20 milhões de euros; coincidindo com a entrada de Portugal no programa de assistência financeira ${ }^{14}$ regista-se nos dois anos seguintes um decréscimo acentuado para o valor mais baixo da série (13 milhões de euros); nota-se alguma recuperação em 2013, mas sempre num patamar substancialmente inferior, que não supera em nenhum ano os 15 milhões de euros e cuja tendência é de decréscimo até 2016; e neste ano o montante situa-se ao nível de 2012, ou seja, num nível mínimo. Este é, portanto, o contexto do presente estudo.

${ }^{14}$ Sobre as políticas culturais em Portugal em tempos de crise ver Garcia et al., 2016. 


\section{METODOLOGIA}

A estratégia metodológica do estudo foi desenhada de acordo com o objetivo traçado pela DGArtes e pela tutela: realizar no âmbito da revisão do MAA uma auscultação das entidades do sector o mais alargada possível. Auscultação que visava contributos prospetivos e não tanto avaliativos. $O$ método de inquérito adotado é extensivo, por questionário escrito, online, mediante convite por e-mail (Bryman e Teevan, 2005: 82-84) com link individualizado para uma plataforma eletrónica especializada (Qualtrics).

Os destinatários do estudo são as entidades do terceiro sector que desenvolvem uma atividade profissional nas áreas das artes. $O$ universo é constituído por estas entidades, registadas na plataforma eletrónica de gestão de apoios da DGArtes até 1 de março de 2017. A unidade do inquérito é a entidade artística, coletiva ou singular.

As matérias que constam do questionário foram incluídas e trabalhadas de acordo com a DGArtes e a tutela. Uma versão final provisória do questionário foi testada com 6 entidades em entrevistas presenciais (ver anexo 1, pré-testes). Do pré-teste resultou a validação global do questionário e também a introdução de várias alterações na formulação e nas questões a colocar. Entre as alterações, uma das mais relevantes foi a recomendação de reforço da garantia de confidencialidade das respostas e do anonimato dos contributos a publicar como condição para assegurar a desejada participação alargada (ver questionário no anexo 2).

O convite à participação foi enviado pela equipa do CIES-IUL para o universo do estudo por e-mail a 14 de fevereiro de 2017 (ver modelo em anexo 3). No e-mail situa-se o quadro de referência do estudo, as instruções de preenchimento e a ligação para a plataforma eletrónica com o questionário.

$O$ desenho do questionário na parte relativa aos contributos foi pensado tendo sempre presente o MAA, o quadro de referência (Foddy, 1996[1993]: 84) das questões formuladas, o que foi enfatizado em diversos momentos e instrumentos do estudo. Consequentemente solicitou-se também amiúde que as respostas refletissem a experiência da entidade na relação com o modelo, e que refletisse os contributos das entidades e não (apenas) do responsável pelo preenchimento. 
O questionário é constituído por uma introdução e dois grupos de questões: I - Caracterização da entidade; II - Contributos sobre o modelo de apoio às artes.

O grupo I, de caracterização, integra 8 grupos de questões, por norma fechadas, cujo fim é apoiar a análise dos contributos recolhidos. O pressuposto é que as respostas tendem a refletir as caraterísticas da entidade.

O grupo II, para recolha de contributos, integra 16 grupos de questões, descrições de experiências e propostas, contributos que as entidades entendessem formular, por norma perguntas abertas (Bardin, 1977: 60-63; Foddy, 1996[1993]: 141 e ss.; Bryman e Teevan, 2005: 84), sobre várias dimensões do Modelo de Apoio às Artes. O pressuposto aqui é que os contributos tendem a refletir o ponto de vista da entidade de acordo com a sua experiência de relação com os apoios.

Como se referiu, nesta parte II o modo de formulação das perguntas é essencialmente aberto, com algumas exceções, que aliás se revelaram muito adequadas: pequena introdução de enquadramento da questão; sugestão ou formalização de opções de resposta em algumas delas; em qualquer caso com pedido de fundamentação da resposta.

As respostas às questões fechadas (sobretudo no grupo I) foram tratadas com software de tratamento estatístico (IBM SPSS) e as abertas (sobretudo no grupo II) com MS Excel e com software de análise qualitativa de conteúdo MAXQDA.

No capítulo cinco, dedicado à análise dos posicionamentos das entidades, os excertos que os ilustram e evidenciam as diferentes perspetivas em presença são transcrições diretas, em geral integrais, e que mantêm a escrita original. As taxas de resposta totais para o conjunto das questões da parte II podem ser consultadas no anexo 5 . 


\section{TRABALHO DE TERRENO E COMUNICAÇÃO}

O trabalho de terreno foi iniciado a 14 de fevereiro de 2017, com o envio massivo de e-mails às entidades registadas na plataforma eletrónica de gestão dos apoios da DGArtes convidando-as à participação no estudo, e terminou a 11 de março de 2017 com a resposta a um último e-mail de esclarecimento.

Procura-se agora dar conta das várias vertentes do trabalho de terreno: desde logo o controlo da listagem das entidades inscritas na referida plataforma, mas também a monotorização de respostas submetidas e de respostas em curso, bem como o acompanhamento de todas as situações suscetíveis de contribuir para a participação do maior número possível de entidades.

\section{Participação alargada das entidades artísticas}

Uma vez que se pretendia que a participação fosse o mais alargada possível, foi mantida a possibilidade de as entidades se registarem na plataforma de gestão de apoios da DGArtes mesmo durante o decurso do inquérito. Assim, a uma listagem inicial de 3.055 entidades registadas naquela plataforma até ao dia 10 de fevereiro de 2017, e após uma triagem de registos, repetidos ou não, adequados ao universo de estudo (como autarquias e outras entidades públicas), foram acrescentados 69 registos de entidades inscritas nesse período (quadro 1), dando assim oportunidade de participar no estudo a mais entidades artísticas. 
Quadro 1. Da listagem inicial à listagem final de entidades registadas

\begin{tabular}{l|r}
\hline & N.o de registos \\
\hline $\begin{array}{l}\text { LISTAGEM INICIAL de entidades inscritas na Plataforma da DGAr- } \\
\text { tes até 10.02.2017 }\end{array}$ & $\mathbf{3 . 0 5 5}$ \\
\hline & 61 \\
\hline $\begin{array}{l}\text { Entidades inscritas na Plataforma da DGArtes entre 10.02.2017 e } \\
\text { Entidades inscritas na Plataforma da DGArtes entre 22.02.2017 e } \\
\text { 01.03.2017 }\end{array}$ & 8 \\
$\begin{array}{l}\text { Registos repetidos ou não adequados ao universo de estudo (i.e., } \\
\text { autarquias e outras entidades) }\end{array}$ & $(-) 46$ \\
\hline \hline LISTAGEM FINAL de entidades registadas & $\mathbf{3 . 0 7 8}$ \\
\hline
\end{tabular}

Fonte: CIES-IUL, EPEA, 2017.

\section{Aplicação do questionário}

A aplicação do questionário decorreu entre 14 de fevereiro de 2017 e 5 de março de $2017^{15}$. O gráfico 2 mostra o cronograma das principais ações realizadas ao longo da aplicação, entre as quais se destaca o envio de e-mails de convite à participação no estudo, o despiste de todas as mensagens de erro no envio (devoluções), o acompanhamento das respostas submetidas e ainda envio de e-mails de insistência para entidades sem resposta à data (lembretes).

Todas estas ações permitiram uma boa evolução do número de respostas submetidas, com grande incremento no último dia do prazo inicialmente estipulado (3 de março de 2017), em que foram submetidas 197 respostas.

\footnotetext{
${ }^{15}$ A data de 3 de março de 2017 foi inicialmente definida como limite para a conclusão do preenchimento do questionário. No entanto, e dando seguimento a várias solicitações por parte de entidades artísticas, foi decidido pela equipa do CIES-IUL estender este prazo por mais dois dias ( 5 de março de 2017) mas apenas para entidades que já tinham iniciado o preenchimento do questionário na plataforma. Esta medida permitiu que fossem submetidas (mais) 16 respostas.
} 


\section{Gráfico 2. Cronograma do trabalho de terreno}

\section{(em números absolutos)}

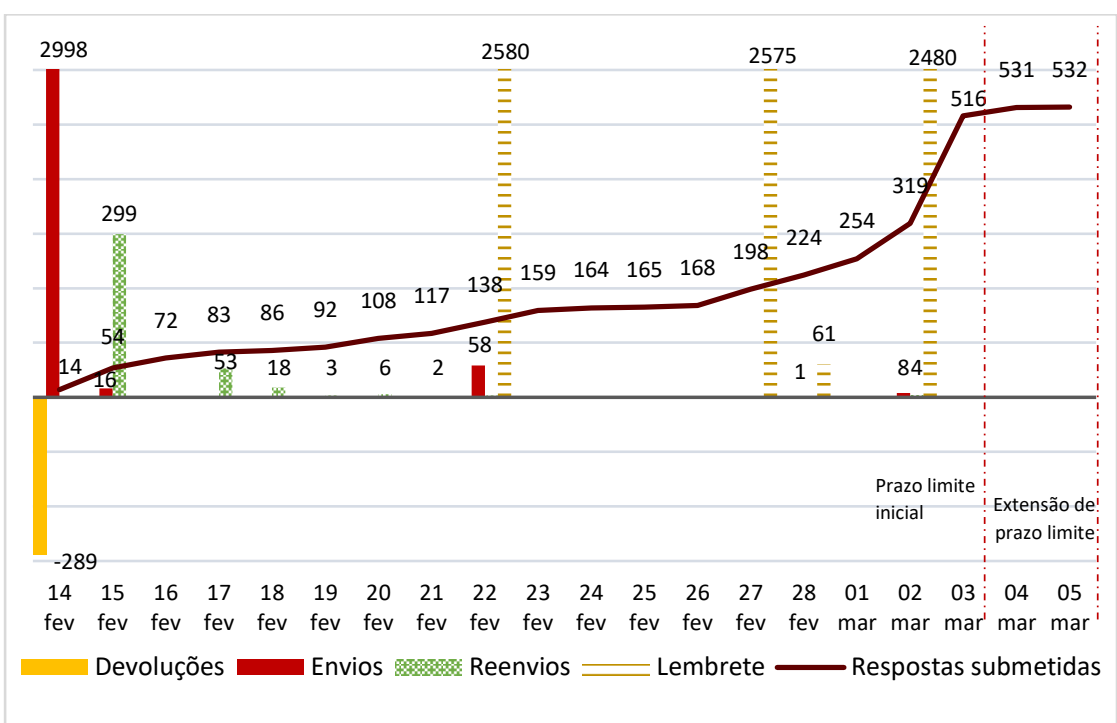

Fonte: CIES-IUL, EPEA, 2017.

\section{Convites à participação}

Logo após o envio massivo de e-mails de convite à participação no estudo (14 de fevereiro de 2017) detetou-se um número significativo de mensagens devolvidas (289).

Após a análise destas mensagens geradas automaticamente, constatou-se uma diversidade de erros reportados. Se, por um lado, foram detetados casos de fácil resolução como endereços que foram, entretanto, alterados com mensagem automática sobre o novo endereço, por outro também foram detetados casos de endereços que deixaram de estar ativos, não foram encontrados ou mesmo que deixaram de existir. Os casos mais complexos prendem-se com os endereços cujo acesso era negado ou bloqueado por filtros de spam ou mecanismos de firewall.

Para esta última situação de bloqueio delineou-se uma estratégia para a ultrapassar usando um outro protocolo ${ }^{16}$ para envio de um e-mail de follow-up às entidades em causa (314, no total).

\footnotetext{
${ }^{16}$ Utilizou-se diretamente a plataforma de e-mail em vez da plataforma de gestão do questionário (Qualtrics).
} 
A este e-mail responderam 79 entidades para as quais, e recorrendo ao mesmo protocolo, foi enviado um link individual de acesso ao questionário. Deste procedimento resultaram 52 respostas submetidas e 8 respostas iniciadas, mas não submetidas.

\section{Acompanhamento da aplicação}

Para acompanhamento do processo de aplicação do questionário foi criado um endereço de e-mail que esteve ativo ao longo de todo o período em que decorreu o trabalho de terreno. O quadro 2 dá conta dos tipos de conteúdos das 253 mensagens rececionadas, todas respondidas com a máxima brevidade e em tempo útil.

Quadro 2. Acompanhamento do questionário: mensagens recebidas por e-mail

\begin{tabular}{l|c}
\hline Conteúdo das mensagens & N.o \\
\hline $\begin{array}{l}\text { Respostas a e-mail de follow up e consequente pedido de envio de acesso ao } \\
\text { questionário }\end{array}$ & 79 \\
$\begin{array}{l}\text { Confirmações de receção de e-mails, agradecimentos e outros assuntos } \\
\begin{array}{l}\text { Dificuldades de acesso à plataforma Qualtrics ou dúvidas sobre perguntas con- } \\
\text { cretas do questionário }\end{array}\end{array}$ & 46 \\
$\begin{array}{l}\text { Informações com novo endereço de e-mail da entidade para envio do link de } \\
\text { acesso ao questionário, informações sobre entidade inativa e/ou não enqua- } \\
\text { drada no universo de estudo }\end{array}$ & 41 \\
$\begin{array}{l}\text { Pedidos de extensão de prazo de submissão do questionário ou pedidos de có- } \\
\text { pia da resposta dada pela entidade }\end{array}$ & 23 \\
$\begin{array}{l}\text { Questões técnicas referentes ao registo na plataforma DGArtes e acesso à pla- } \\
\text { taforma Qualtrics }\end{array}$ & 15 \\
\begin{tabular}{l} 
Respostas recebidas em ficheiro pdf \\
\hline
\end{tabular} & Total \\
\hline
\end{tabular}

Fonte: CIES-IUL, EPEA, 2017. 


\section{Da listagem final de entidades inscritas na plataforma eletrónica da DGArtes ao universo de trabalho}

Foram várias as vias utilizadas pelas entidades para fazer chegar à equipa de investigação informações "extra" questionário, mas que se afiguram cruciais para o apuramento do universo de trabalho. Já se referiu que, por via do endereço de e-mail disponibilizado para o estudo, chegaram as informações sobre entidades inativas e/ou não enquadrada no universo de estudo e, por via das mensagens de erro de envios devolvidos, foi possível identificar registos extintos ou inativos.

A estas duas vias acresce mais uma outra. Seguindo boas práticas de investigação científica, foi dada a possibilidade das entidades artísticas, caso assim o entendessem, optarem por não participar no estudo (opt-out ou anulação da subscrição) ${ }^{17}$. Esta possibilidade, gerida automaticamente pela plataforma Qualtrics, consistia na disponibilização de um link ${ }^{18}$ que permitia à entidade bloquear imediatamente qualquer futura comunicação a propósito deste estudo.

Todas estas informações, recolhidas (a propósito de e) durante a aplicação do questionário permitiram um apuramento mais fino do universo de trabalho (quadro 3).

Quadro 3. Da listagem final ao universo de trabalho

\begin{tabular}{|c|c|}
\hline & N. de registos \\
\hline (A) Listagem final de entidades registadas & 3.078 \\
\hline $\begin{array}{r}\text { Opt-out, anulação de subscrição (pelas próprias entidades na plataforma } \\
\text { Qualtrics) }\end{array}$ & 16 \\
\hline $\begin{array}{r}\text { Desadequação ao universo (informação remetida à equipa do CIES por e- } \\
\text { mail) }\end{array}$ & 16 \\
\hline $\begin{array}{r}\text { Entidade inativa, extinta ou cessou atividade (informação remetida à } \\
\text { equipa do CIES por e-mail) }\end{array}$ & 4 \\
\hline Registos repetidos & 48 \\
\hline Endereços de $e$-mail inativos, suspensos ou inexistentes & 207 \\
\hline (B) CASOS ANULADOS POR INQUÉRITO & 291 \\
\hline UNIVERSO DE TRABALHO (A-B) & 2.787 \\
\hline
\end{tabular}

Fonte: CIES-IUL, EPEA, 2017.

${ }^{17}$ Este procedimento está de acordo com o Código de Conduta na Investigação ISCTE-IUL (2016).

18 Este link estava presente em toda a comunicação por e-mail, designadamente nos convites à participação e nos lembretes (ver anexos 3, 4 e 5). 


\section{Do universo de trabalho à amostra}

O convite à participação enviado por e-mail incluía um link de acesso ao questionário online ${ }^{19}$, tendo 532 entidades concluído o preenchimento e submetido as respostas, 371 iniciado o preenchimento, mas não submetido as respostas e 57 apenas acedido à plataforma sem iniciar o preenchimento (quadro 4).

Quadro 4. Participação no estudo

\begin{tabular}{l|r|r}
\hline \multicolumn{1}{c|}{ Participação } & N.․․ & \% \\
\hline Respostas submetidas & 532 & 19,1 \\
Respostas iniciadas, mas não submetidas & 371 & 13,3 \\
Acessos à plataforma sem início do questionário & 57 & 2,0 \\
Sem ter acedido à plataforma & 1.827 & 65,6 \\
\hline \multicolumn{1}{r|}{ TOTAL (universo de trabalho) } & $\mathbf{2 . 7 8 7}$ & $\mathbf{1 0 0 , 0}$ \\
\hline
\end{tabular}

Fonte: CIES-IUL, EPEA, 2017.

Seguiram-se dois critérios de validação das respostas submetidas: i) as entidades terem respondido a pelo menos uma pergunta da parte II do questionário (contributos); e ii) estarem incluídas no universo de trabalho. Dos dez questionários não validados, oito referem-se a entidades que não responderam a qualquer das questões da parte II e dois a entidades que estão fora do universo de trabalho (neste caso, autarquias).

Assim, das 532 respostas submetidas, apenas 10 não foram consideradas válidas, pelo que a base de análise do estudo é constituída por 522 questionários válidos.

A este total de 522 questionários válidos correspondem cerca de 16 mil segmentos/unidades de análise referentes a respostas dadas às perguntas (abertas) do questionário.

Em conclusão, a amostra do estudo corresponde a uma participação bastante elevada tendo em conta a metodologia online utilizada (Bryman e Teevan, 2005: 84). É também, como se verá no próximo capítulo, uma amostra muito diversificada quer em termos de perfis de entidades artísticas quer em termos de relação com os apoios da DGArtes.

$19 \mathrm{O}$ link de acesso era único por entidade. Por esse mesmo motivo, o preenchimento poderia ser feito através de vários computadores ou dispositivos, revisto e alterado a qualquer momento sem perder informação. 


\section{AMOSTRA}

Como se viu no capítulo anterior, a amostra, base da análise deste estudo, é constituída por 522 questionários válidos e decorre de um processo com uma elevada participação. Este capítulo é inteiramente dedicado à caracterização das entidades participantes e visa enquadrar os contributos recolhidos na segunda parte do questionário, a parte central do ponto de vista dos objetivos do estudo.

O capítulo está dividido em três partes: uma primeira onde se caracterizam as entidades que compõem a amostra, tendo em conta variáveis como a área artística principal, o domínio de atividade, o regime jurídico (pessoa jurídica e natureza jurídica), a data de fundação e o orçamento para 2016. A segunda parte é dedicada ao historial das entidades com os apoios da DGArtes (e suas antecedentes). A partir de cruzamentos sistemáticos caracterizam-se os 3 tipos de relação das entidades com estes apoios - Teve apoio (pelo menos uma vez), Concorreu, mas nunca teve apoio e Nunca concorreu. Na terceira e última parte recorre-se a citações das respostas das entidades para ilustrar os motivos para a não participação.

Como se verá ao longo deste capítulo, a amostra segue, em termos gerais, as características das entidades inscritas na plataforma da DGArtes, não se evidenciando desvios significativos suscetíveis de enviesar de algum modo o conjunto de contributos em análise. Inclui não apenas entidades beneficiárias dos apoios (que são cerca de metade da amostra), mas também aquelas que concorreram mas nunca obtiveram apoio e as que nunca concorreram - cerca de um quarto da amostra cada (ver adiante gráfico 12).

\section{Caracterização das entidades}

Como referido anteriormente, o questionário incluía uma primeira parte, de preenchimento obrigatório, com um conjunto de questões com o objetivo de caracterizar as entidades, designadamente no que se refere à sua tipologia ou domínio de atividade, à área artística principal, ao regime jurídico (pessoa e natureza jurídica), à localização geográfica, à data de fundação, ao orçamento para 2016 e ao historial de apoios da DGArtes.

Quanto à tipologia (ou domínio) de atividade (gráfico 3), a maioria das entidades (51\%) enquadra-se numa tipologia mista - que compreende criação e 
programação. As entidades dedicadas exclusivamente à criação representam $41 \%$ da amostra e as dedicadas exclusivamente à programação $9 \%{ }^{20}$.

\section{Gráfico 3. Tipologia de atividade}

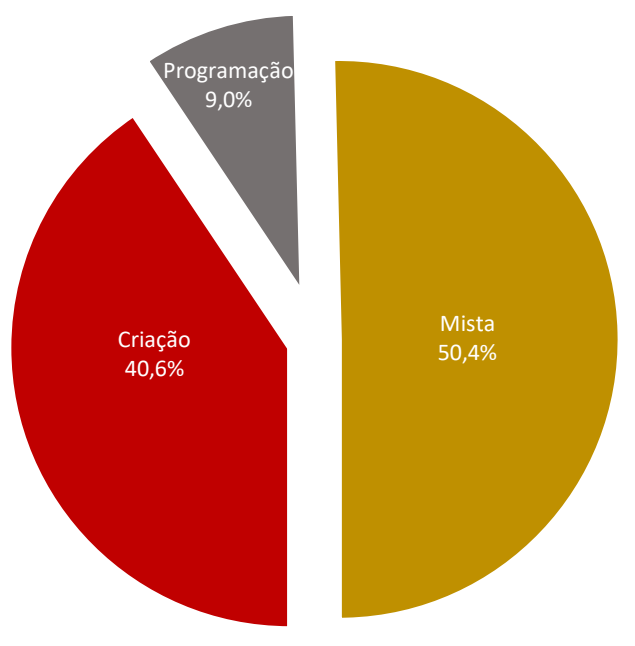

Base: $\mathrm{n}=522$

Fonte: CIES-IUL, EPEA, 2017.

Já quanto à área artística principal das entidades que constituem a amostra (gráfico 4), a mais representada é a do teatro (30\%), a que se segue a música (24\%), os cruzamentos disciplinares (15\%), a dança (10\%) e as artes plásticas (9\%). Com um peso em redor dos $2 \%$ estão as áreas de arquitetura, design, fotografia e artes digitais.

Quase 6\% das entidades não se enquadram nestas áreas (pré-definidas no questionário por corresponderem às do MAA) mas sim em "outras" tão diversas como: circo, cinema, banda desenhada, performance, design de moda, objetos e figurinos, edição (de livros), investigação artística, exposições, literatura, media digitais, paisagem, património cultural imaterial, perfinst, rádio, videoarte e videojogos.

${ }^{20}$ Esta distribuição segue de forma muito próxima os dados administrativos da DGArtes (ver, por exemplo, distribuição das entidades por domínios artísticos nos apoios plurianuais de 2015). 
Gráfico 4. Área artística principal

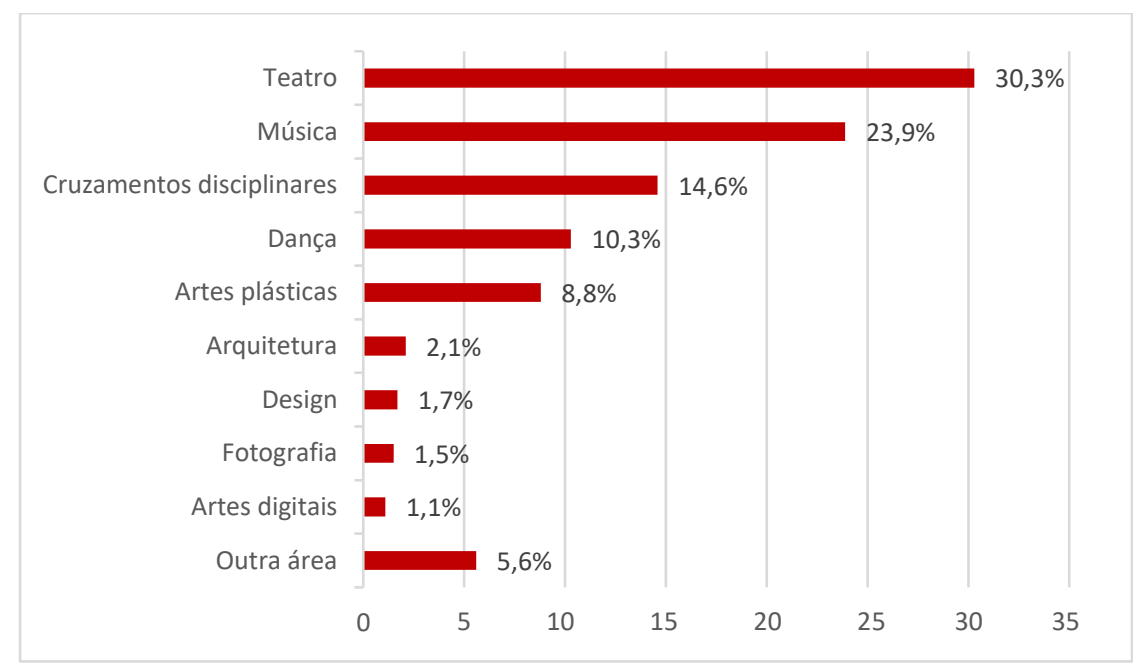

Base: $n=522$

Fonte: CIES-IUL, EPEA, 2017.

Um indicador (possível) de aferição entre o universo de trabalho e a amostra deste estudo prende-se com as entidades com candidatura. Assim, a comparação da distribuição por área artística principal em cada um dos contingentes considerados (e.g., os dados administrativos das candidaturas a apoios da DGArtes, por um lado, e um segmento da amostra com candidatura à DGArtes, por outro) permite constatar poucas diferenças estruturais (quadro 5). À exceção do teatro (sobrerrepresentado neste segmento da amostra com $+14,6 \%$ em detrimento dos cruzamentos disciplinares - 15.5\%), as demais áreas têm diferenças pouco significativas, nunca ultrapassando uma diferença de $\pm 5 \%$. 


\section{Quadro 5. Entidades com candidatura}

\begin{tabular}{|c|c|c|c|}
\hline \multirow{2}{*}{ Área artística principal } & DGArtes & EPEA & \multirow{2}{*}{$\begin{array}{l}\text { Dif. } \\
\text { (\%) }\end{array}$} \\
\hline & $\%$ & $\%$ & \\
\hline Arquitetura & 2.9 & 2.1 & -0.7 \\
\hline Artes digitais & 1.9 & 1.1 & -0.8 \\
\hline Artes plásticas & 9.7 & 6.4 & -3.3 \\
\hline Cruzamentos disciplinares & 31.0 & 15.5 & -15.5 \\
\hline Dança & 7.2 & 11.8 & 4.6 \\
\hline Design & 2.7 & 1.3 & -1.3 \\
\hline Fotografia & 2.8 & 1.6 & -1.2 \\
\hline Música & 20.0 & 23.8 & 3.8 \\
\hline Teatro & 21.8 & 36.4 & 14.6 \\
\hline
\end{tabular}

Fontes: DGArtes, entidades registadas na plataforma à data de 10-02-2017, que apresentaram candidaturas à DGArtes (1.735); CIES-IUL, EPEA, 2017, entidades que tiveram apoio, ou concorreram, mas não tiveram apoio, e que se enquadram numa das áreas consideradas na DGArtes (374, com exclusão de respostas "outras áreas").

Como se verá adiante neste capítulo, outros indicadores disponíveis referentes apenas às entidades beneficiárias de apoios ${ }^{21}$ mostram que a distribuição da amostra relativamente à área artística principal segue, sem desvios significativos, a estrutura das entidades apoiadas.

Das entidades que compõem a amostra deste estudo, uma larga maioria (79\%) são, juridicamente, pessoas coletivas. Apenas $21 \%$ são pessoas singulares (gráfico 5).

${ }^{21}$ Dados administrativos sobre a distribuição das entidades apoiadas por área artística (2015), mas também os que se referem a 2014 (Borges e Lima, s/ data). 


\section{Gráfico 5. Pessoa jurídica}

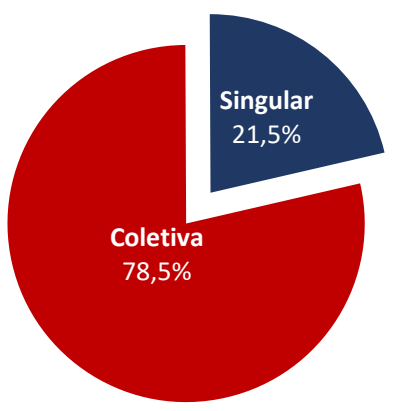

Base: $\mathrm{n}=522$

Fonte: CIES-IUL, EPEA, 2017.

Destaca-se a associação (59\%) como forma de organização coletiva (gráfico 6), a que se segue, a larga distância, uma diversidade de outras formas de organização (coletiva e singular) entre as quais se destaca empresário em nome individual (8\%), cooperativa e sociedade por quotas (ambas com 6\%).

\section{Gráfico 6. Natureza jurídica}

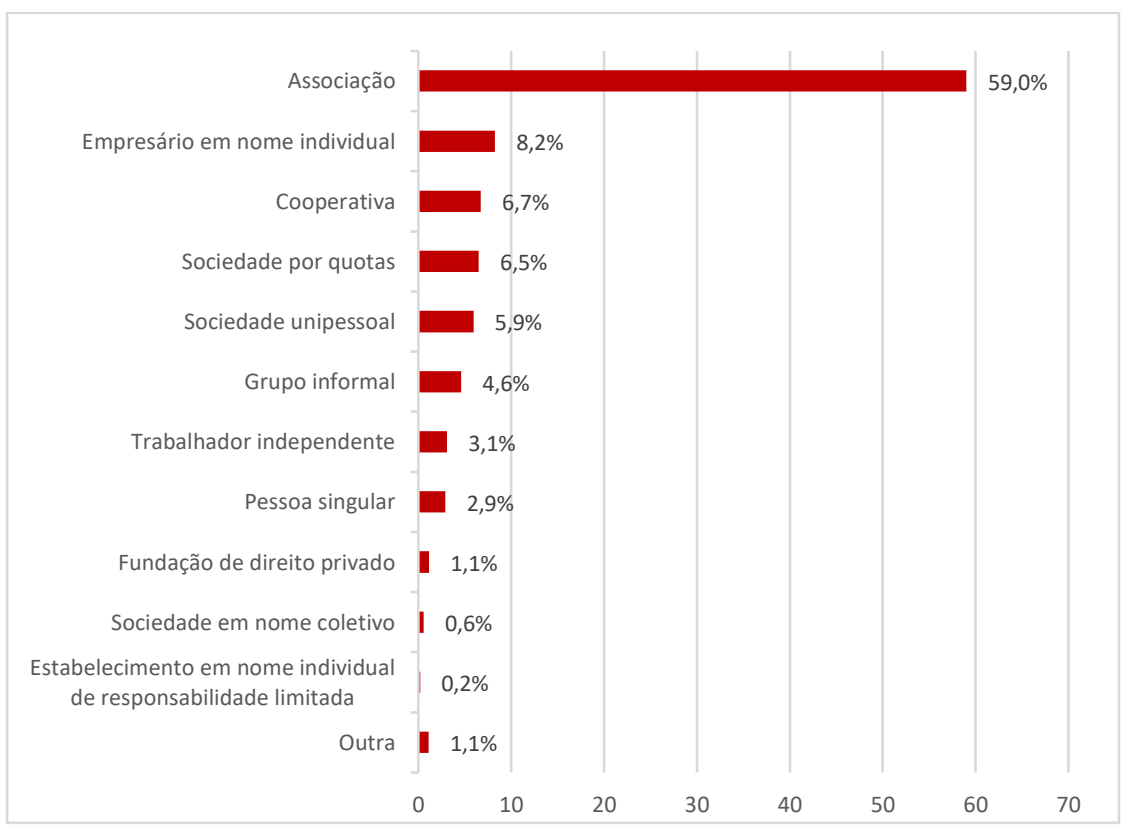

Base: $n=522$

Fonte: CIES-IUL, EPEA, 2017. 
Quanto ao sector de atividade, a grande maioria das entidades (72\%) que compõem a amostra pertencem, como se esperaria tendo em conta os destinatários dos apoios, ao terceiro sector (gráfico 7). A presença de entidades artísticas cuja atividade se enquadra do ponto de vista organizacional ou organizativo no sector privado lucrativo ( $28 \%$ da amostra) é conhecida e não é propriamente recente (Gomes, Lourenço, e Martinho, 2006) até tendo em conta as áreas consideradas nos apoios às artes. Na composição destas entidades destacam-se as entidades singulares e correspondente natureza jurídica individual (por exemplo empresário e unipessoal) e, quanto às áreas artísticas, a música e as artes plásticas.

\section{Gráfico 7. Sector de atividade}

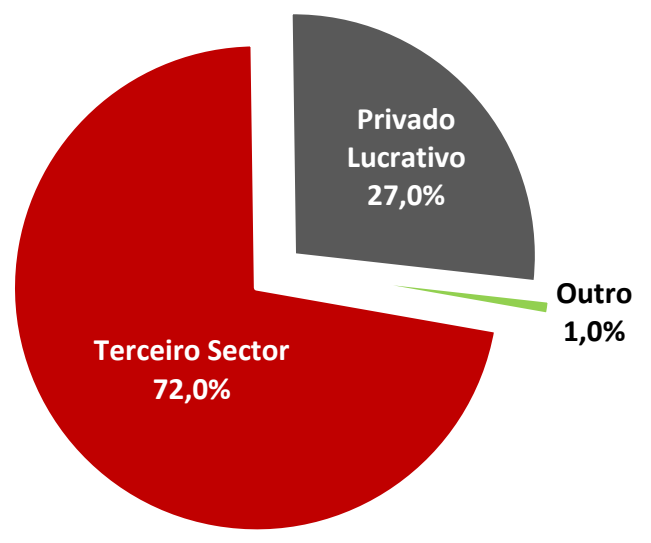

Base: $n=522$

Fonte: CIES-IUL, EPEA, 2017.

Nota: nova variável construída a partir da Q3_Natureza Jurídica. Neste caso, terceiro sector compreende: associação, cooperativa, fundação de direito privado e grupo informal. Privado lucrativo compreende empresário em nome individual, sociedade em nome coletivo, sociedade por quotas, sociedade unipessoal, estabelecimento em nome individual de responsabilidade limitada, pessoa singular e trabalhador independente.

Outro refere-se, sobretudo, a casos em que informação é escassa e não permite classificação nas outras duas categorias. 
Quanto à localização geográfica (gráfico 8), ressalta a já conhecida concentração das sedes das entidades em grandes centros urbanos ${ }^{22}$, com especial destaque para a Área Metropolitana de Lisboa (46\%), seguida da região Norte (24\%) e da região Centro (18\%). A região do Alentejo e do Algarve representam $7 \%$ e $4 \%$, respetivamente. As outras situações representadas (2\%) referem-se a entidades cuja sede está localizada nas regiões autónomas da Madeira ou dos Açores, no estrangeiro ou mesmo entidades com múltiplas localizações.

\section{Gráfico 8. Região onde está localizada a sede da entidade}

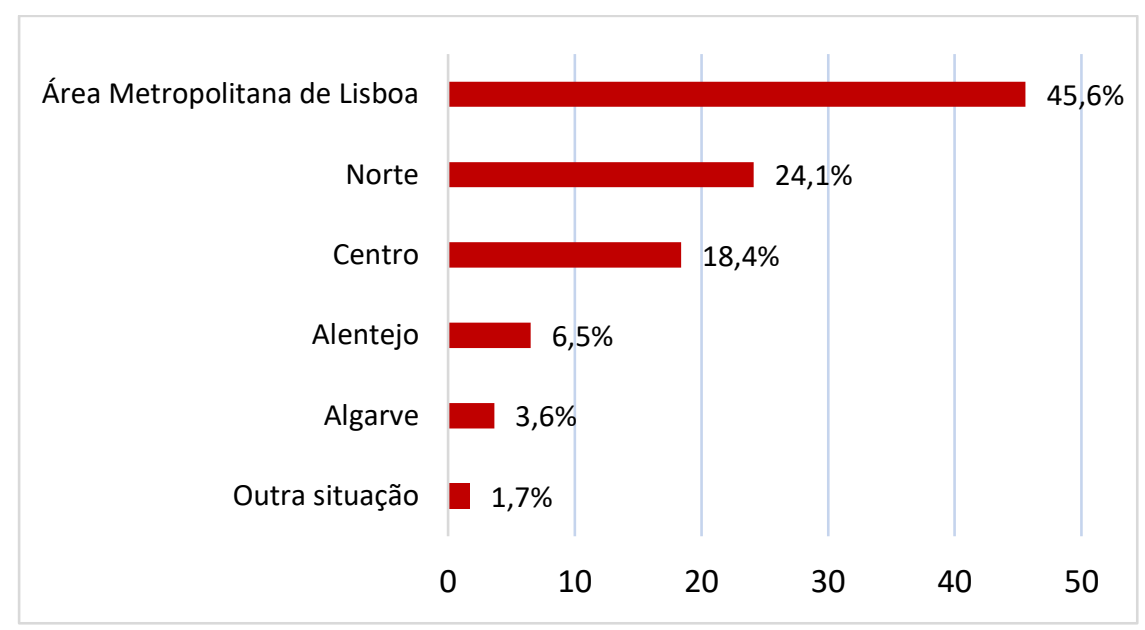

Base: $\mathrm{n}=522$

Fonte: CIES-IUL, EPEA, 2017.

Um outro aspeto de caracterização relevante prende-se com a antiguidade das entidades que constituem a amostra, entendida aqui como data de fundação e/ou início de atividade profissional. Mais de metade (61\%) das entidades que compõem a amostra foi criada depois de 2001, representando uma parte significativa aquelas que foram criadas nos últimos 6 anos (25\%) (gráfico 9).

\footnotetext{
${ }^{22}$ Sobre a concentração da criação artística nas regiões das áreas metropolitanas de Lisboa e Porto, ver Borges e Lima ( $\mathrm{s} /$ data). Ainda sobre a distribuição geográfica das entidades, refira-se que na amostra do estudo ( $n=522)$ estão representadas entidades artísticas de 90 concelhos e de acordo com os dados administrativos da DGArtes as entidades que apresentaram candidatura $(n=1.735)$ estão distribuídas por 167 concelhos.
} 
Gráfico 9. Data de fundação/início de atividade profissional (escalões)

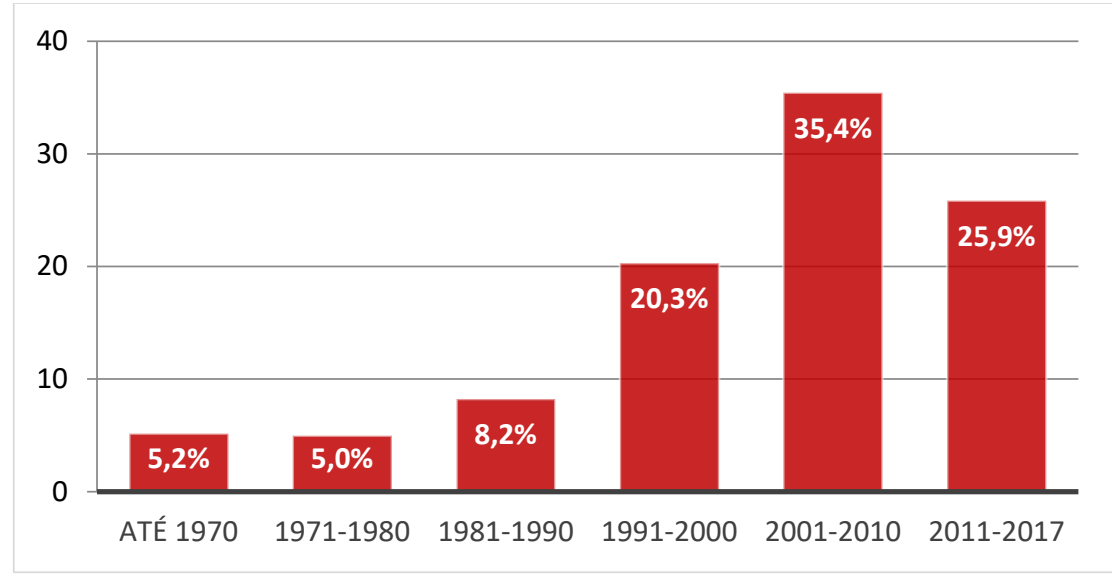

Base: $n=522$

Fonte: CIES-IUL, EPEA, 2017.

Em muitos casos a data de fundação não corresponde ao início de atividade, como está patente em alguns dos depoimentos de entidades recolhidos a este propósito.

66 A Associação foi legalizada [em 2015] para enquadrar o trabalho profissional de um grupo informal de criadores que colaboravam desde 2008 com o mesmo nome.

[527 - teatro, teve apoio]

64 a atividade profissional iniciou-se em 1996, mas a entidade só se legaliza como Associação Cultural em 1998.

[330 - teatro, teve apoio]

A este fenómeno da ambiguidade entre o início de atividade e a criação de um enquadramento institucional acresce um outro referente às reconfigurações sucessivas que, ao longo do tempo, as entidades são objeto ${ }^{23}$.

${ }^{23}$ Nesta primeira parte do questionário consta uma pergunta de resposta facultativa: Q6.1 Se a entidade presente sucede a outra, e considerar útil para situar melhor a relação com o apoio às artes, pode referir sinteticamente esse historial. A taxa de resposta é $13 \%$. 
66 A entidade [sociedade unipessoal criada em 2013] sucede ao regime de empresário em nome individual e nunca recebeu qualquer apoio, apesar de se ter candidatado várias vezes, exercer actividade profissional desde 2000 e ter participado em mostras internacionais.

[132 - artes plásticas, concorreu mas nunca teve apoio]

66 Passou a sociedade unipessoal em 2001. Antes era empresa em nome individual [qu] sucedeu a [uma] cooperativa do sector cultural, extinta em 1995.

[441 - teatro, teve apoio]

O gráfico 10 permite ainda uma outra leitura relacionada com o impacto da regulamentação dos apoios no sector das artes: $82 \%$ das entidades foram fundadas após 1990 (primeira regulamentação dos apoios, então ao teatro) e quase metade (mais precisamente 47\%) após 2006 com a regulamentação do atual Modelo de Apoio às Artes.

\section{Gráfico 10. Data de fundação/início de atividade profissional}

(em valores absolutos)

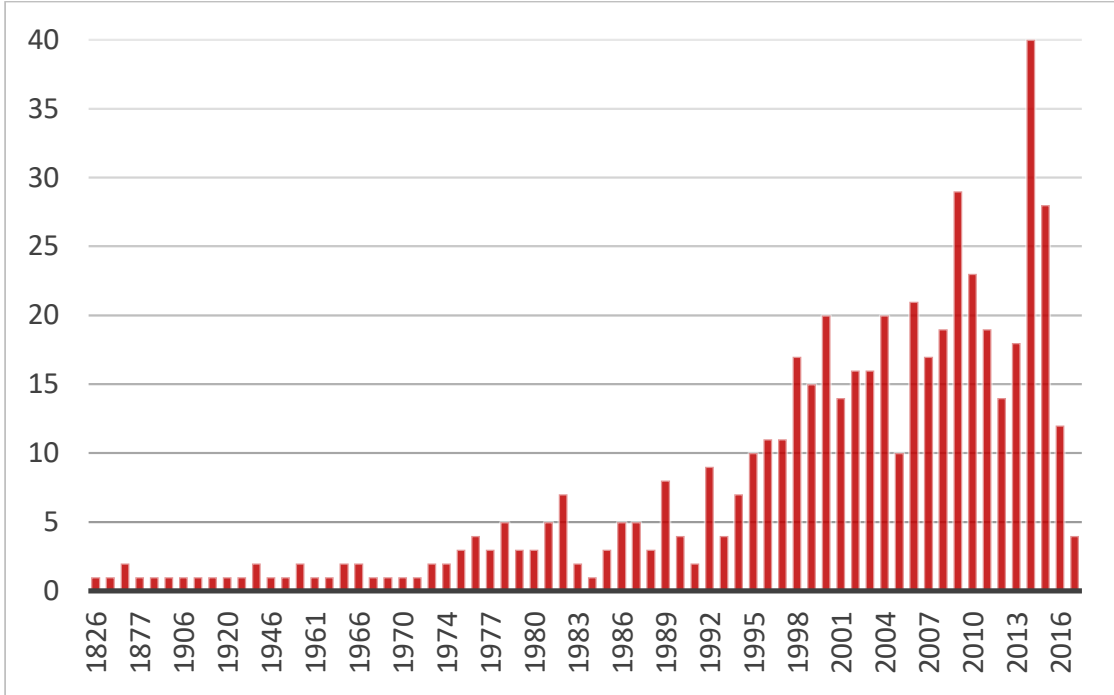

Base: $n=522$

Fonte: CIES-IUL, EPEA, 2017. 
A importância destes apoios às artes para a estruturação do sector é bem evidenciada por depoimentos das entidades a propósito da sua data de fundação.

66 [Em 2001, a entidade] é criada para formalizar o coletivo já existente perante a DGArtes (na altura Instituto das Artes) e assim poder concorrer aos apoios.

[334 - teatro, teve apoio]

6 A [entidade] foi um projeto [...] com inicio em 1998, tendo tido sempre apoio pontual (ou equivalente) enquanto projeto d[e uma] associação - anos 1999 a 2002. Em 2002 autonomizou-se, tendo-se criado uma estrutura legal (associação) separada [da anterior].

[479 - dança, teve apoio]

6 Grupo informal criado pontualmente para a realização do projeto de Internacionalização das Artes apoiado e promovido pela DGARTES.

[104 - cruzamentos disciplinares, nunca concorreu]

O valor do orçamento das entidades para o ano 2016 também permite a caracterização da amostra deste estudo (gráfico 11). Evidencia situações muito diversificadas (desde a inexistência de orçamento até orçamentos com valores superiores a $500.000 €$ ) que mostram que estão presentes entidades de diferentes escalas. Constata-se uma incidência de orçamentos baixos ( $40 \%$ tem orçamento anual até $10.000 €$ e $17 \%$ não tem sequer orçamento), em particular em entidades singulares e em entidades muito recentes. 
Gráfico 11. Orçamento das entidades em 2016

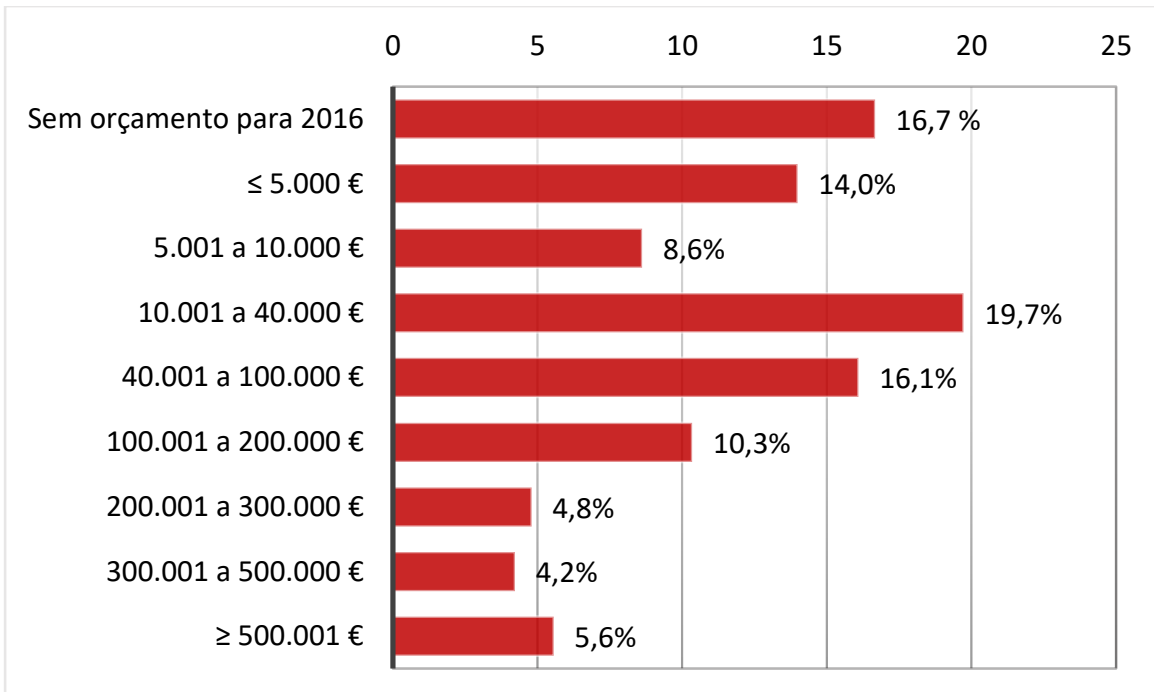

Base: $\mathrm{n}=522$

Fonte: CIES-IUL, EPEA, 2017.

\section{O historial de apoios das entidades que compõem a amostra}

Perto de metade da amostra (51\%) é constituída por entidades que, pelo menos por uma vez, beneficiaram de apoio por parte da DGArtes ou de entidades que Ihe antecederam (como IPAE, IAC, IA) (gráfico 12). A outra metade da amostra é constituída por entidades que, apesar de terem concorrido a este tipo de apoios, nunca o chegaram a obter (25\%), mas também por entidades que, por diferentes motivos, nunca concorreram $(24 \%)^{24}$.

\footnotetext{
${ }^{24}$ Apesar de nunca terem concorrido, estas entidades são potenciais interessadas em concorrer. Esta é, assim, uma confirmação de uma mobilização alargada de entidades participantes neste estudo.
} 


\section{Gráfico 12. Historial de apoios das entidades}

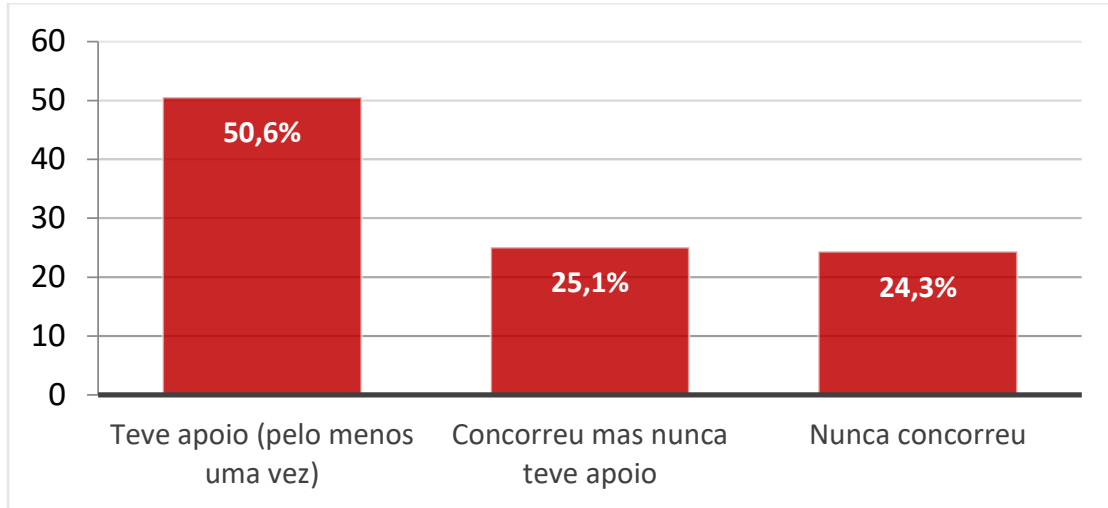

Base: $n=522$

Fonte: CIES-IUL, EPEA, 2017.

O cruzamento pela área artística principal (gráfico 13) permite constatar que todos os tipos de relação com os apoios estão representados em todas as áreas artísticas.

Mas, para além desta constatação, outros aspetos parecem relevantes. Antes de mais, a já conhecida incidência das entidades apoiadas na área do teatro (38\% das que tiveram apoio), que é seguida, em menor escala, pelas entidades apoiadas na área da dança (13\%). Já relativamente aos que nunca concorreram, é relevante a incidência das entidades nas áreas da música, artes plásticas e outra área artística ${ }^{25}$.

Quanto aos cruzamentos disciplinares e a arquitetura, estas parecem ser as áreas em que é menor a incidência das entidades inquiridas beneficiárias uma vez que os valores para "Concorreu mas nunca teve apoio" são mais elevados do que para os restantes tipos de relação.

${ }^{25}$ Ver adiante neste capítulo motivos para nunca terem concorrido. 
Gráfico 13. Área artística principal por relação com o historial de apoios da DGArtes (em percentagem do número de casos)

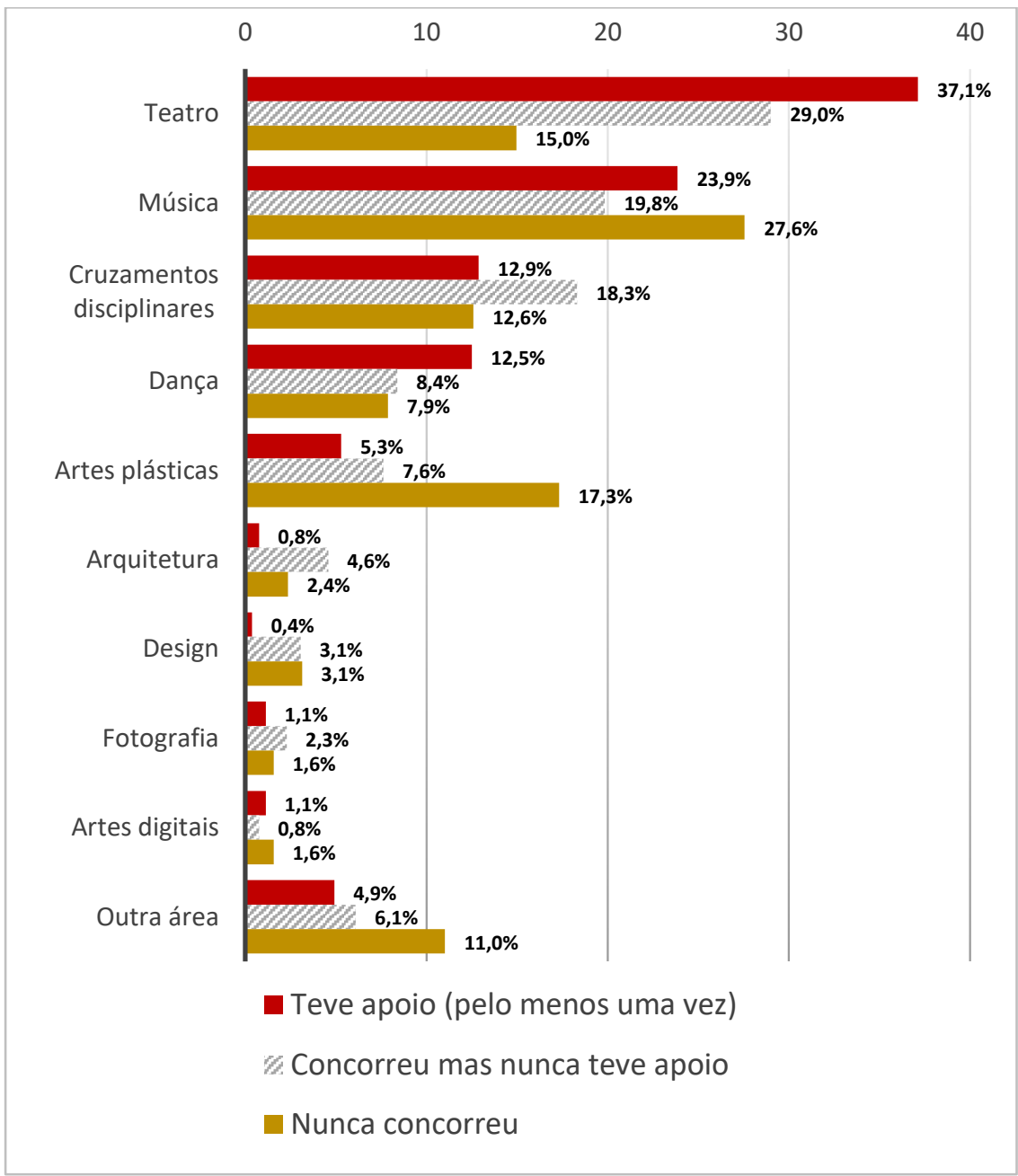

Base $=522$

Fonte: CIES-IUL, EPEA, 2017.

Um outro aspeto a ter em conta prende-se com as modalidades de apoio a que as entidades inquiridas se candidataram ou beneficiaram. O gráfico 14 evidencia que a amostra compreende um leque diversificado de entidades beneficiárias e candidatas a todas as modalidades de apoio em vigor desde 2006. Destaca-se com maior evidência o apoio direto pontual (25\% das entidades da 
amostra teve apoio nesta modalidade e $19 \%$ candidatou-se, mas nunca teve apoio).

Gráfico 14. Modalidades de apoio de que beneficiaram as entidades que tiveram apoio e a que se candidataram entidades que nunca tiveram apoio

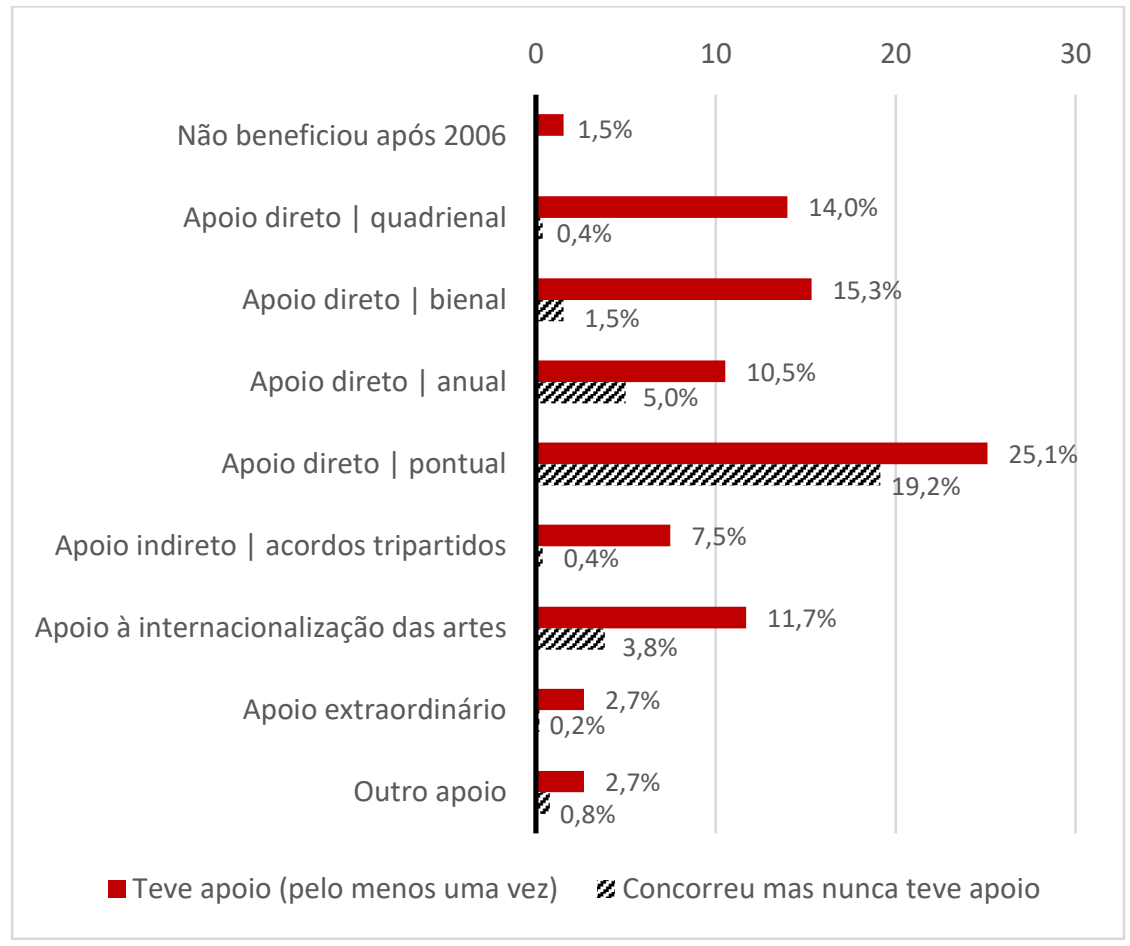

(Base: $n=522$, resposta múltipla para cada um dos contingentes: teve apoio e concorreu mas nunca teve apoio)

Fonte: CIES-IUL, EPEA, 2017.

O quadro 6 cruza as variáveis de caracterização com o historial de apoios. Comparando o total da amostra, constata-se que para as entidades que nunca concorreram ou que concorreram mas nunca obtiveram são particularmente significativas as situações em que as entidades são pessoas singulares (32\% e $35 \%$ respetivamente, face ao total da amostra, $22 \%$ ).

Já quanto ao sector de atividade, evidencia-se que os apoios são predominantes em entidades do terceiro sector ( $81 \%$, contra total $72 \%$ ). 
Quadro 6. A amostra segundo o historial de apoios

(percentagens em coluna)

\begin{tabular}{|c|c|c|c|c|}
\hline & \multicolumn{3}{|c|}{ Historial de apoios } & \multirow[b]{2}{*}{ Total } \\
\hline & $\begin{array}{l}\text { Teve apoio } \\
\text { (pelo menos } \\
\text { uma vez) }\end{array}$ & $\begin{array}{l}\text { Concorreu } \\
\text { mas nunca } \\
\text { teve apoio }\end{array}$ & $\begin{array}{c}\text { Nunca } \\
\text { concorreu }\end{array}$ & \\
\hline Número de casos & 264 & 131 & 127 & 522 \\
\hline \multirow[t]{4}{*}{ Tipologia de atividade } & & & & \\
\hline & 39,4 & 42,0 & 41,7 & 40,6 \\
\hline & 9,1 & 5,3 & 12,6 & 9,0 \\
\hline & 51,5 & 52,7 & 45,7 & 50,4 \\
\hline \multicolumn{5}{|l|}{ Área artística (agregada) } \\
\hline Artes performativas & 75,4 & 60,3 & 53,5 & 66,3 \\
\hline Artes visuais & 7,6 & 17,6 & 26,8 & 14,8 \\
\hline Cruzamentos disciplinares & 13,6 & 18,3 & 12,6 & 14,6 \\
\hline Outras & 3,4 & $*$ & 7,1 & 4,4 \\
\hline \multicolumn{5}{|l|}{ Pessoa jurídica } \\
\hline Coletiva & 90,2 & 65,6 & 67,7 & 78,5 \\
\hline Singular & 9,8 & 34,4 & 32,3 & 21,5 \\
\hline \multicolumn{5}{|l|}{ Sector de atividade } \\
\hline Terceiro sector & 80,7 & 65,6 & 58,3 & 71,5 \\
\hline Privado lucrativo & 18,6 & 32,8 & 40,2 & 27,4 \\
\hline Outro & $*$ & $*$ & $*$ & 1,1 \\
\hline \multicolumn{5}{|l|}{ Região da sede } \\
\hline Norte & 26,1 & 23,7 & 20,5 & 24,1 \\
\hline Centro & 18,6 & 18,3 & 18,1 & 18,4 \\
\hline Área Metropolitana de Lisboa & 45,5 & 47,3 & 44,1 & 45,6 \\
\hline Alentejo & 6,8 & 6,1 & 6,3 & 6,5 \\
\hline Algarve & 2,3 & $*$ & 6,3 & 3,6 \\
\hline Outra situação & * & $*$ & 4,7 & 1,7 \\
\hline
\end{tabular}


(...)

\begin{tabular}{|c|c|c|c|c|}
\hline Fundação/início de atividade & & & & \\
\hline Até 1970 & 3,8 & 6,1 & 7,1 & 5,2 \\
\hline $1971-1980$ & 8,0 & $*$ & $*$ & 5,0 \\
\hline $1981-1990$ & 9,8 & 6,9 & 6,3 & 8,2 \\
\hline $1991-2000$ & 28,4 & 13,0 & 11,0 & 20,3 \\
\hline $2001-2010$ & 40,5 & 32,8 & 27,6 & 35,4 \\
\hline 2011-2017 & 9,5 & 38,2 & 47,2 & 25,9 \\
\hline Orçamento para 2006 & & & & \\
\hline Sem orçamento para 2016 & 10,2 & 22,9 & 23,6 & 16,7 \\
\hline$\leq 5.000 €$ & 5,7 & 18,3 & 26,8 & 14,0 \\
\hline 5.001 a $10.000 €$ & 2,3 & 16,8 & 13,4 & 8,6 \\
\hline 10.001 a $40.000 €$ & 22,3 & 17,6 & 16,5 & 19,7 \\
\hline 40.001 a $100.000 €$ & 19,7 & 16,0 & 8,7 & 16,1 \\
\hline 100.001 a $200.000 €$ & 16,3 & * & 4,7 & 10,3 \\
\hline 200.001 a $300.000 €$ & 7,6 & * & * & 4,8 \\
\hline 300.001 a $500.000 €$ & 7,6 & $*$ & $*$ & 4,2 \\
\hline$>500.001 €$ & 8,3 & $*$ & $*$ & 5,6 \\
\hline
\end{tabular}

Fonte: CIES-IUL, EPEA, 2017.

Nota: $\left({ }^{*}\right)$ As percentagens reportam-se a menos de 6 casos.

\section{Motivos invocados pelas entidades para nunca terem concorrido aos apoios}

Exclusivamente para as entidades que afirmaram nunca ter concorrido aos apoios financeiros da DGArtes (24\% da amostra) foi perguntado sobre os motivos dessa não participação ${ }^{26}$.

Os motivos invocados pelas entidades são diversos. Desde logo, os meramente circunstanciais (não adequado ou não oportuno) mas também os que se prendem com a falta de informação ou o desconhecimento da existência destes apoios. Para aqueles que ainda assim tiveram intenção de se candidatar, são invocados motivos como o não cumprimento das condições de elegibilidade do modelo de apoio (designadamente no que se refere à localização geográfica, à natureza jurídica e ao tempo de atividade), mas também as dificuldades específicas no processo de candidatura e a desconfiança face ao processo de seleção.

${ }^{26}$ Q11d. Identifique por favor os principais motivos para nunca ter concorrido aos apoios financeiros disponibilizados pela DGArtes. A taxa de resposta é 100\% (pergunta obrigatória). 
Para algumas das entidades inquiridas, o facto de não terem concorrido deve-se a motivos meramente circunstanciais: ou seja, não ter sido adequado ou oportuno.

6 Nenhum [motivo] especifico. Estivemos focados mais em redes internacionais e programas de apoio local e europeu onde fomos promotores e prestadores de serviços na área comunitária,

[339 - cruzamentos disciplinares, nunca concorreu]

66 Como profissional na área das artes plásticas inserido no "mercado da arte " através das galerias não tenho sentido necessidade de apoio. Arrisco eu nos meus projectos

[359 - artes plásticas, nunca concorreu]

6 Uma vez que a companhia tem um pequeno subsídio municipal, foi decisão da direcção adquirir algum historial antes de concorrer aos apoios da DGArtes.

[322 - teatro, nunca concorreu]

66 Desde a sua fundação, só nos últimos três anos a entidade possuiu uma estrutura adequada ao desenvolvimento de projectos dignos de financiamento. Porém durante os últimos três anos, ou nunca se conseguiu um projecto, que ao ver da entidade, fosse estruturado o suficiente para financiamento ou os prazos de candidatura eram demasiado apertados.

[353 - música, nunca concorreu]

66 Não estávamos preparados. Não havia experiência suficiente para redigir projetos ganhadores.

[337 - cruzamentos disciplinares, nunca concorreu]

\section{Falta de informação e desconhecimento sobre os apoios}

O desconhecimento da existência deste tipo de apoios e da sua aplicabilidade a determinadas áreas e domínios artísticos é invocado por algumas entidades.

6 Desconhecimento sobre os programas de apoio existentes e respectivo enquadramento.

[120 - artes plásticas, nunca concorreu] 
6 não temos conhecimento de apoios ou simplesmente não existem para a especificidade dos projetos que desenvolvemos.

[323 - música, nunca concorreu]

6 falta de informação sobre a abertura de candidaturas

[362 - música, nunca concorreu]

6 Não recebo informações sobre os concursos a decorrer

[60 - outra área, nunca concorreu]

6 pq não existe informação pertinente às empresas, funciona como "cluster" sempre para os mesmos,

[78 - cruzamentos disciplinares, nunca concorreu]

\section{Não cumprimento das condições de elegibilidade}

Alguns depoimentos recolhidos evocam as condições de elegibilidade que as entidades não preenchem. Por exemplo, o facto de serem apenas elegíveis as entidades com residência fiscal em Portugal continental e que aí exerçam a sua atividade (excluem-se, deste modo, as atividades e entidades sediadas nas regiões autónomas dos Açores e da Madeira e fora do país).

66 Ter sede e domicílio fiscal na Região Autónoma da Madeira e ser impedido pela legislação em vigor de fazê-lo

$$
\text { [72 - dança, nunca concorreu] }
$$

66 Residia fora de Portugal.

[219 - artes digitais, nunca concorreu]

O não cumprimento de outros critérios, designadamente a constituição de uma entidade com personalidade jurídica de direito privado ou a precedência de um histórico de concurso, são motivos invocados pelas entidades inquiridas.

66 Por não ter um grupo devidamente formado para participar nestas iniciativas. [104 - cruzamentos disciplinares, nunca concorreu] 
6 Alguns concursos terem a necessidade de tempo mínimo de actividade que ainda não preenchemos. Todos os concursos terem a necessidade de experiência prévia comprovada de criação ou produção o que limita o acesso inicial aos mesmos.

[67 - dança, nunca concorreu]

\section{Dificuldade no processo de candidatura}

Um elevado número de entidades evoca dificuldades em levar a bom termo o processo de candidatura. E estas dificuldades sentem-se a diversos níveis: o (apertado) calendário para apresentação do dossiê de candidatura, a dificuldade em reunir toda a documentação necessária (em especial o comprovativo por parte de entidades parceiras) e em preencher os formulários.

6 As datas de anúncio de abertura de concurso são extremamente tardias o que impossibilita preparação eficaz do projecto artístico e recolha de documentação obrigatória para execução das candidaturas.

[523 - dança, nunca concorreu]

66 Na altura em que pretendíamos concorrer o tempo previsto para a preparação da candidatura era demasiado pequeno (um mês), e calhou na altura de férias da grande maioria das entidades com quem pretendíamos trabalhar.

[1 - artes plásticas, nunca concorreu]

6 Os concursos contêm uma vertente empresarial com demasiado peso, particularmente em questões como gestão de projecto e e uma previsão de gastos tão rigorosa que obriga a recorrer a uma empresa para tratar das candidaturas. No fundo o dinheiro é desviado da criação artística para as competências empresariais.

[258 - artes plásticas, nunca concorreu]

Para estas entidades artísticas, a complexidade e a burocracia do processo de candidatura são dissuasoras da participação. A excessiva parametrização dos formulários, a quantidade de documentação solicitada e a falta de flexibilidade para as especificidades de cada uma das áreas artísticas são alguns dos elementos invocados. 
6 Processo burocrático, face à estrutura administrativa que a associação possui.

[80 - música, nunca concorreu]

66 O processo de candidatura é bastante complexo, comparado por exemplo com as bolsas da Gulbenkian e com outras bolsas internacionais, e exige um enorme investimento de tempo face ao numero de apoios que concede.

[131 - artes plásticas, nunca concorreu]

66 Processo demasiado burocrático. Formulário e plataforma online de candidatura desajustados à descrição de projetos individuais de criação e investigação artísticas.

[11 - artes plásticas, nunca concorreu]

66 A excessiva aferição paramétrica da caracterização das iniciativas no que refere à participação e tipologia dos públicos; não é ponderada a hipótese das práticas artísticas também englobarem processos e iniciativas que nem procuram público nem são pensadas para qualquer tipo de público específico: como a àrvore que cai na floresta e ninguém ouve nem sabe que caiu pode acontecer que haja situações estético-expressivas, performativas, conceptuais que dispensam o testemunho e a experiência directa.

[136 - artes plásticas, nunca concorreu]

Em alguns casos as entidades artísticas não conseguem fazer face à complexidade processual, tendo por vezes que recorrer a serviços externos

6 Anterior estrutura organizacional insuficiente para elaboração das candidaturas.

[493 - música, nunca concorreu]

66 Não tendo orçamento para pagar a um especialista nem tempo para dedicar ao preenchimento dos formulários, sigo utilizando outras formas de financiamento, ou seja, ganho o dinheiro a dar aulas e tento vender os espectáculos.

[193 - música, nunca concorreu]

6 Tentámos fazer candidatura, mas a plataforma pede informações que são complicadas de completar, pois o Diretor da Companhia, é também técnico de luz, som, coreógrafo, faz o marketing, etc. Como não temos possibilidade de pagar a alguém para fazer esse tipo de trabalho. Na plataforma é pedido sempre o 
valor orçamental para todos esses cargos, sendo o Diretor quem faz esse trabalho é muito dificil concorrer pois estaria a colocar o seu nome em todos estes critérios.

[22 - dança, nunca concorreu]

\section{Desconfiança face ao processo de seleção}

Outras entidades evocam o processo de seleção dos projetos como motivo para a sua não participação. Descrença, desconfiança, falta de reconhecimento de mérito artístico dos jurados escolhidos para avaliar as propostas e falta de transparência no processo de seleção dos projetos a apoiar são alguns dos argumentos recolhidos.

6 Não fiz candidaturas, primeiro, por pensar que esta atribuição de fundos pode já estar reservada a determinados grupos, grupos já conhecidos e bem posicionados no mercado

$$
\text { [104 - cruzamentos disciplinares, nunca concorreu] }
$$

6 Conhecimento de que as verbas disponíveis são escassas e que as entidades já apoiadas têm sempre alguma vantagem inicial.

$$
\text { [420 - cruzamentos disciplinares, nunca concorreu] }
$$

6 Os apoios são geralmente atribuídos a estruturas maiores e mais experientes, com capacidade de auto-financiamento de parte do orçamento dos projetos apresentados.

$$
\text { [53 - teatro, nunca concorreu] }
$$

6 Também em boa verdade sofro do preconceito, pois nunca concorri em nome individual, e acho que o processo é complicado e pouco claro na atribuição favorecendo os amigos e cheio de " CUNHAS". Tenho esta impressão desde que fiz parte de um projecto colectivo a concurso na área do teatro.

$$
\text { [359 - artes plásticas, nunca concorreu] }
$$

66 Por fim, não reconheço ao Juri destes apoios, pelo menos nestes últimos anos, qualidade critica. $\mathrm{O}$ juri deveria ser reconhecido pelo meio artístico.

$$
\text { [131 - artes plásticas, nunca concorreu] }
$$


Registam ainda outras respostas que evidenciam as dificuldades dos artistas individuais emergentes em participar nestes concursos e ainda um desajustamento face a algumas áreas artísticas.

66 Como individual nunca concorri. Todo o processo é muito complicado para alguém que não domina os meandros dos projetos e por vezes é a opção de trabalhar ou fazer os projetos, tenho optado por trabalhar enquanto outros fazem os projetos.

[164 - dança, nunca concorreu]

6 Porque as probabilidades de apoiarem uma artista em inicio de carreira são praticamente impossíveis, por esse motivo nunca concorri, além do mais raramente apoiam projectos individuais, ou pelo menos é esta a ideia que se tem da DGARTES.

[138 - artes plásticas, nunca concorreu]

6 Comecei a fazer a candidatura e percebi que estava muito vocacionada para instituições ou grupos de teatro ou dança. Aliás, vê-se pelos resultados que há uma elevada preferência pelas artes do espetáculo. É extremamente burocrático e favorece aspectos mais institucionais. Tem de haver também apoio aos artistas que trabalham a nível independente.

[5 - artes plásticas, nunca concorreu]

6 Visto que a nossa associação actua sensivelmente no campo da arquitectura, é do nosso entender que a DGArtes e os modelos de apoio financeiro, não estão adaptados para as necessidades destes campos. Isto dificulta a proposta assim como os campos de actividade que possam receber apoio financeiro da DGArtes.

[102 - arquitetura, nunca concorreu]

66 Não tenho conhecimento de que a DGArtes contemple apoios para a produção de cinema independente e de baixo orçamento, (minha actividade principal) ou de apoios à organização/curadoria de videoarte e cinema experimental não narrativo.

[196 - outra área, nunca concorreu]

6 As nossas áreas artísticas principais, nomeadamente Artes de Rua e Circo Contemporâneo, não estão contempladas nos apoios financeiros atribuídos pela DGArtes.

[486 - outra área, nunca concorreu] 
66 Ao contrário do que acontece noutros outros países europeus e do mundo ocidental, videojogos não são considerados arte em Portugal, e não existem apoios específicos para a área. Estão num limbo entre software e cultura.

[185 - outra área, nunca concorreu]

66 Desconfiança de a DGArtes alguma vez apoiaria Banda Desenhada - área artística híbrida que se confunde com os apoios à literatura devido ao suporte do livro...

[59 - outra área, nunca concorreu] 


\section{OS POSICIONAMENTOS}

Neste capítulo analisam-se os posicionamentos das entidades. Segue-se a ordem das questões tal como foram inquiridas na parte II do questionário. A estratégia expositiva dos contributos segue uma lógica comum nos vários pontos: (i) breve enquadramento da questão ou grupo de questões; (ii) apresentação de dados estatísticos quando aplicável ${ }^{27}$; (iii) leitura global das principais temáticas que a análise de conteúdo revela, identificando-se as tendências que emergem dos posicionamentos, bem como as diferentes temáticas em presença; (iv) transcrições diretas dos contributos das entidades, em geral integrais $^{28}$, e em que se manteve a escrita original, com exceção dos sublinhados, da responsabilidade da equipa para destacar determinadas temáticas. Os contributos, com que se procura evidenciar as diferentes perspetivas e que são suscetíveis de melhor ilustrar as temáticas em causa, são referenciados às entidades de modo codificado, para salvaguarda de anonimato, com os seguintes elementos:

[número de questionário - área artística principal, relação com os apoios]

As taxas de resposta totais por questão da parte II podem ser consultadas no anexo 5.

\section{Modalidades de concurso por tipologia de atividade (criação/programação)}

Sobre as modalidades de concurso por tipologia de atividade procurou-se recoIher contributos sobre qual a solução considerada mais adequada: manter (como tem acontecido maioritariamente no MAA) num mesmo concurso ou se-

\footnotetext{
${ }^{27}$ As percentagens expressas neste capítulo, tanto no corpo do texto como nos gráficos, têm sempre por base a amostra $(n=522)$.

${ }^{28}$ A utilização de parêntesis retos nas citações ([...]) indica que parte do texto foi retirado para garantir a regra do anonimato ou porque não diretamente relacionado com a temática em análise. Por outro lado, pode indicar também que foi acrescentado algum elemento informativo para melhor se entender o sentido do texto.
} 
parar, tomando como exemplo o programa de apoios pontuais de 2016. Na formulação da questão ${ }^{29}$ sugerem-se assim duas opções de resposta. Estas opções constituem o núcleo central da codificação. Na fundamentação da resposta a grande maioria das entidades situa-se por referência às duas opções propostas no enunciado da questão. Separar, com $58 \%$, é a solução que recolhe o apoio da maioria das entidades. Manter recolhe $17 \%$. Outras entidades posicionam-se face à questão colocada, mas apresentam argumentos a favor quer de uma quer de outra (código "Depende”, 5\%). Finalmente, algumas há que divergem da questão colocada, não tomam posição, nem condicionada, ou situam-se fora do enquadramento da pergunta (posicionamento aqui codificado como "Opinião difusa", 9\%).

Tanto entre as posições que defendem que se deve manter como entre aquelas que consideram que haverá que separar é possível perceber posições de apoio incondicional, por um lado, e condicional, por outro.

\section{Manter concursos únicos}

\section{Incondicional}

Uma grande parte das entidades que defendem a manutenção de um concurso único para criação e programação (17\%) argumenta de forma veemente que não há criação artística sem programação, que estas são atividades complementares e interdependentes, pelo que os concursos devem ser conjuntos.

Argumentam ainda que uma grande parte das entidades artísticas em Portugal se dedica de forma simultânea a estas duas atividades, pelo que a manutenção do concurso único é a opção mais adequada à realidade atual das estruturas artísticas. Até porque, sustentam algumas entidades, esta é a opção que melhor facilita o entrecruzamento entre áreas.

A manutenção dos concursos únicos seria, assim, o processo mais democrático uma vez que todas as entidades concorrem em pé de igualdade.

Este posicionamento é reforçado à luz da experiência (pouco favorável para algumas destas entidades) da opção tomada em 2016 de separar em concursos diferentes o programa de apoios pontuais. Para algumas entidades (de tipologia

\footnotetext{
${ }^{29}$ Q12. Os apoios à criação e à programação têm sido maioritariamente atribuídos num mesmo concurso, sem distinção ou separação. Do ponto de vista da entidade, será de manter esta opção ou será de os separar em concursos diferentes (por exemplo, como no programa de apoios pontuais de 2016)? Por favor fundamente a resposta. A taxa de resposta é $88 \%$.
} 
mista, subentende-se) esta opção implicou uma duplicação de trabalho de preparação das candidaturas.

66 Achamos importante manter os apoios em conjunto, não achamos viável a separação. Muitas das entidades são mistas, fazem criação e programação (acoIhimento). Dividir estas duas categorias poderá desvalorizar e até limitar uma delas dentro das entidades.

[265 - dança, teve apoio]

66 Esta modalidade deve ser atribuída sem separação, isto é a criação faz parte da programação e a programação engloba, abraça a criação, na descrição pormenorizadas destas, elas são referidas como um conjunto de atividades de uma temporada.

[39 - dança, nunca concorreu]

66 Será melhor manter. Na verdade, as candidaturas efectuadas cruzaram normalmente ambas as áreas. A sua distinção dificultará a compreensão na natureza híbrida de algumas propostas.

[197 - cruzamentos disciplinares, concorreu mas nunca teve apoio]

6 Achamos que o modelo actual será o mais apropriado até porque no nosso caso temos as duas situações no mesmo projecto. Caso separassemos iria haver uma separação de concursos que iria prejudicar a nossa situação.

[402 - música, teve apoio]

64 A criação e a programação estão geneticamente interligadas, pelo que devem ser consideradas em conjunto. Mesmo no caso de artes não performativas, a programação deve ser parte integrante do projeto, na medida em que o investimento de dinheiros públicos deve ter um resultado apresentado à sociedade civil. Assim, os apoios à criação e à programação devem ser atribuídos num mesmo concurso.

[424 - música, teve apoio]

6 Do nosso ponto de vista, enquanto estrutura mista, os apoios à criação e programação deveriam continuar a ser atribuídos num mesmo concurso. Em estruturas mistas como a nossa, a criação e a programação fazem muitas das vezes parte de um pensamento de direção artística que cria uma relação de complementaridade entre os projetos de criação e de programação, atuando em conjunto para um mesmo objetivo e estratégia artística.

[488 - teatro, teve apoio] 
4 Do nosso ponto de vista, esta opção deverá ser mantida tal como está devido ao facto de, a grande maioria das estruturas profissionais fora de grandes centros urbanos, embora sejam estruturas que têm a criação como atividade principal, mantêm também atividades de programação [...], como tal concorrem como entidades mistas. Como tal, não nos parece útil, produtivo nem prático, separar a programação e a criação em concursos diferentes.

[503 - teatro, teve apoio]

66 Preferência pelos concursos sem distinção ou separação. Mais democráticos, permitindo que todos concorram ao mesmo tempo e mesmo pé de igualdade, permitindo mais fácil cruzamentos com outras áreas, permitindo um escrutínio mais directo, franco, em relação aos actos da administração. A alteração de 2016 não foi discutida com o sector, nem explicada. Trata-se de uma imposição - como infelizmente é a norma - de cima para baixo. Não é assim que o sector deseja ser tratado pela administração.

[408 - dança, teve apoio]

66

Retomar os concursos sem distinção. A separação de 2016 trouxe consigo diferenças iníquas, como, p.ex., permitir que a "criação" continuasse a trabalhar a partir de referências internacionais, enquanto que à "edição" se cerceou esta possibilidade, optando uma via claramente nacionalista. Não nos revemos nesta deriva nacionalista, aliás não discutida nem sequer explicada ao sector. O próprio é que a criação, edição, etc, portuguesa, se nutra e confronte com a produção europeia e internacional. Tratou-se de uma ulterior categorizarão dos concursos, já categorizados, sub-categorizados, sub-sub- e assim por diante. Descomplique-se! Trata-se de políticas manifestamente mal gizadas. Reforcem-se os mecanismos de escrutínio da administração por parte dos interessados, juntando, e não dividindo. Ao pretender prosseguir pela segunda via a administração projecta de si própria uma imagem verdadeiramente sofrível.

[515 - cruzamentos disciplinares, teve apoio]

66 Consideramos importante manter o apoio à criação e à programação no mesmo concurso. Por experiência em anos anteriores, os concursos separados obrigaram a estrutura a trabalho extra na apresentação de projetos, dificultando a coordenação das atividades e uma programação atempada e financeiramente sustentável. Simultâneamente o concurso conjunto permite uma avaliação global dos projetos de cada estrutura.

[363 - dança, teve apoio] 


\section{Condicional}

Uma outra parte das entidades que defendem a manutenção de um concurso único para criação e programação colocam um conjunto de condições. Deve ser considerada a identidade e o trabalho desenvolvido pelas entidades em cada uma destas áreas (e não apenas nas duas áreas em simultâneo), sendo sugerido o estabelecimento de quotas ou mesmo numerus clausus. Sugere-se a criação de (novos) concursos dedicados à difusão e promoção nacional e internacional para espaços de acolhimento ou para entidades que apenas fazem programação.

66

Deve manter-se um único concurso. O principal fundamento assenta na nossa forte convicção de que a criação tem de ser "comunicada". Por outro lado para projetos exclusivamente de criação ou de programação poder-se-á estabelecer quotas.

[94 - cruzamentos disciplinares, concorreu mas nunca teve apoio]

6

Creio que não é aconselhável separar as áreas de apoio em concursos diferentes, pois num determinado ano podem haver mais propostas de programação do que de criação; ou as propostas de criação podem ser muito mais interessantes do que as de programação. A que me parece mais justa é haver numerus clausus; limites superiores e inferiores para cada área, ou seja, definir que, por exemplo, pelo menos $x$ projectos de programação/criação serão apoiados, até um máximo de y. Isso permite que os projectos mais interessantes e válidos sejam mais valorizados, independentemente da sua área.

[73 - teatro, concorreu mas nunca teve apoio]

G6 Achamos que deveriam contemplar pelo menos dois campos de acção principal, evitando ter que se escolher entre a programação e a criação. É por esta escolha entre um campo e outro ser imposta, não havendo lugar a uma 3a via que os apoios de criação e programação devem manter-se sem distinção, uma vez que este tipo de distinção poderia implicar que uma atividade anulasse a outra e isso seria contraproducente. Além disso, as entidades são maioritariamente entidades mistas, pelo que não faria qualquer sentido diferenciar. $\mathrm{O}$ que sim se deveria distinguir era entre entidades mistas e entidades só de acolhimento, devendo existir um concurso só para espaços de acolhimento tais como Teatros Municipais e afins.

[369 - artes plásticas, teve apoio]

6 Sim, achamos que deve ser mantida a opção de os apoios à criação e à programação serem atribuídos num mesmo concurso. No entanto, idealmente, deve 
ser respeitada a identidade de cada estrutura no seu trabalho com cada uma destas áreas. Se cada uma destas áreas não for devidamente considerada, os apoios devem ser separados. Preocupa-nos que determinadas áreas, com pesos diferentes nas diferentes estruturas, possam ser subvalorizadas, como é o caso da área pedagógica, na sua relação direta com os processos de criação artística. Para que sejam respeitadas as identidades de cada estrutura e para que os apoios à criação e programação vão ao encontro dessa identidade, terá que haver um esforço de conhecimento da parte do financiador relativamente às estruturas que são financiadas. Neste sentido, sugerimos que possa haver uma estratégia de relacionamento/acompanhamento da DGArtes em relação às estruturas apoiadas.

[410 - teatro, teve apoio]

6 Na nossa opinião, devido à quantidade de entidades que são criadoras e programadoras esta modalidade deveria-se manter. Porem deveria existir outro tipo de tipologias, como por exemplo: difusão e promoção nacional e internacional.

[438 - teatro, teve apoio]

\section{Separar concursos}

\section{Incondicional}

Os depoimentos que defendem a separação dos concursos (maioritários na amostra do presente estudo, como se referiu anteriormente) argumentam que as atividades de criação e programação são de natureza distinta. Elas distinguem-se pelos modos de funcionamento, o tipo de profissionais envolvidos e até as diferentes necessidades financeiras. Argumenta-se que criação e programação não deveriam depender uma da outra para obtenção de apoios e que neste contexto deve ser dada primazia à criação artística.

Defende-se ainda que a separação dos concursos permitiria uma maior transparência e clareza nos processos de instrução (e.g., formulários adequados) e de avaliação (e.g., permitiria comparar o comparável).

Esta solução possibilitaria ainda a abertura de concursos desfasados no tempo, facto que é visto como uma vantagem quer para as estruturas quer para os serviços da DGArtes.

G6 É importante distinguir o que é diferente. A criação e a programação podem ter concursos diferentes eventualmente em períodos diferentes. Num sistema de Apoio às Artes que visa promover e assegurar a produção artística contemporânea tem necessariamente de haver uma relação estrutural entre a criação 
e a programação - ambas devem partilhar objectivos matriciais mas ocupar lugares distintos neste processo. À criação deve ser dada uma atenção primordial dotando os projectos da autonomia necessária à definição e prossecução dos seus objectivos artísticos. A programação deve promover o encontro dos projectos de criação com o público. Uma entidade programadora deve ser conhecedora da natureza dos projectos artísticos que seleciona e deve ter em conta o contexto em que estes são apresentados - públicos, território, etc.

[530 - teatro, teve apoio]

6

Por uma questão organizacional e também de equidade, na nossa opinião faria mais sentido existir uma separação entre os concursos. Ao serem em datas separadas, pode ajudar às entidades concorrentes aos apoios, nomeadamente as estruturas voluntárias, a disporem de mais tempo para melhor prepararem as candidaturas o que resultará num potencial incremento da qualidade das mesmas. Do lado da DGartes, os serviços que lidam com a receção, tratamento e decisão sobre as candidaturas, beneficiaram de mais tempo para uma melhor análise destas, diminuindo os tempos de resposta nestes serviços. Cremos que contribuirá para um aumento generalizado da eficiência de todo o processo, beneficiando os agentes culturais - e responsabilizando-os - a uma atividade cultural de qualidade.

$$
\text { [493 - música, nunca concorreu] }
$$

66

Penso que faria sentido separar os diferentes concursos para ser possível as entidades participarem em vários apoios. Por exemplo, no nosso caso, que trabalhamos como programadores culturais e galeria de arte, podemos ter interesse em nos candidatarmos a apoios à programação e à internacionalização. Assim sendo, teríamos interesse em ter os apoios em alturas separadas.

$$
\text { [1 - artes plásticas, nunca concorreu] }
$$

6 A criação e a programação são duas actividades bastante diferentes e específi-

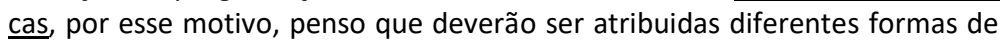
avaliação destas modalidades, não devendo ser concorrentes per si.

$$
\text { [3- design, nunca concorreu] }
$$

6 Concursos diferentes. Em entidades com poucos recursos, a preparação de dossiers relativos a candidaturas com naturezas diferentes é mais vantajosa uma vez que há mais tempo preparar os respetivos dossiers.

[11 - artes plásticas, nunca concorreu] 
46 Não temos experiência na participação em concursos. Mas parece-nos que a separação entre criação e programação permitiria aumentar o número de candidaturas a cada modalidade e, em consequência, elevar a qualidade e o interesse das candidaturas.

[13 - outra área, nunca concorreu]

66 Penso que deveriam ser separados para que cada concurso de foque num determinado tipo de apoio e se avaliem os concorrentes em igualdade de circustanências e critérios, sem dispersão. Tudo o que puder ser feito para que as candidaturas sejam avaliadas - e verificadas a posterior - com rigor e equanimidade, será sempre de interesse.

[16 - teatro, nunca concorreu]

66 Sou a favor da separação das lógicas de programação e de criação. - A programação está associada a um paradigma de: produto, venda, públicos, ou pedagogia e educação. - A criação é a área mais frágil e por isso deve ser apoiada a fundo perdido. Está relacionada com investigação e com a descoberta de mundos porvir. Ou seja, desejavelmente, raramente encaixa em lógicas já pré-estabelecidas. Ou quando acontece faz por subvertê-las. Por isso, não faz sentido uma proposta de criação já ter apoios à partida. Os orçamentos são difíceis de construir quando se quer trabalhar em verdadeiras lógicas de ruptura e de desterritorialização. Os programadores, hoje em dia, arriscam muito pouco em programas verdadeiramente abertos. Também por isso, defendo apoios pontuais de criação com uma lógica de construção de orçamento e de formulários muito diferente da actual [...].

[31 - dança, teve apoio]

6 Penso que a segmentação traz mais rigor na análise e maior clareza dos objetivos de cada programa. Se realizados em alturas diferentes, permitirá também maior disponibilidade dos serviços no apoio aos candidatos e maior rapidez nos processos.

[42 - música, teve apoio]

6

Do nosso ponto de vista, achamos que deve ser feita uma separação concursal. Achamos as duas modalidades bastante importantes e estruturantes para a cultura em Portugal, daí dar-Ihes mais importância, separando os concursos. E, assim, as entidades que praticam só criação, não têm necessidade de também começarem a fazer programação, pois isso trás vantagens a nível de concurso misto.

[45 - dança, concorreu mas nunca teve apoio] 
66 Estes apoios devem ser distintos. Não nos parece que possam ser analisados da mesma forma pois tem objectivos diferentes. As instituições não têm todas as mesmas capacidades e se umas estão mais vocacionadas para a criação outras estão para a programação. Não se pode analisar tudo no mesmo concurso pois estarão a cometer-se erros grosseiros.

[52 - música, nunca concorreu]

66 Será de separar em concursos diferentes desde que isso não implique qualquer corte nos montantes a atribuir para cada uma das opções. São atividades de natureza absolutamente distinta. A criação não deve ser misturada com a programação porque não podem depender uma da outra na atribuição de apoios. Uma entidade deve poder propor-se apenas à criação ou à programação dependendo da natureza do projeto em que se está a focar e deve ainda ter a possibilidade de concorrer a ambas as modalidades.

$$
\text { [55 - teatro, concorreu mas nunca teve apoio] }
$$

66

Deveriam ser apoios atribuídos separadamente, em concursos distintos. Desta forma poderia haver uma maior controlo, nos diferentes âmbitos envolvidos, tanto por parte da entidade gestora dos apoios, quanto dos artistas/estruturas sobre a aplicação dos recursos recebidos.

$$
\text { [72 - dança, nunca concorreu] }
$$

6 A DGArtes devia criar concursos DESBUROCRATIZADOS e TRANSPARENTES para apoiar a CRIAÇÃO e canalizar verbas para os criadores poderem fazer a PROMOČ̃̃O dos seus trabalhos. Para que se tornem conhecidos do grande público e, minimamente rentáveis. A PROGRAMAÇÃO é uma área que não devia estar incluída no âmbito das artes. Os programadores são "técnicos" que nada têm a ver com o processo criativo e, na esmagadora maioria dos caos em Portugal, sem qualquer formação académica - não existem cursos superiores para programadores - ou artística, quando não são pessoas eminentemente da área da política! Não vejo qualquer razão nem vantagem - a não ser para o programadores - em juntar concursos para duas coisas tão distintas.

[85 - dança, teve apoio]

6 No nosso entender, seria de separar. A criação e a programação têm não só naturezas distintas, como modos de funcionamento bastante divergentes, pelo que a criação sai fragilizada se comparada com a sistematização e profissionalização (condições de trabalho), da maior parte das estruturas ou programadores.

[125 - teatro, concorreu mas nunca teve apoio] 
66 Devia-se separar os concursos, até incluir formação se não for considerada como programação. São por natureza diferentes em actividades internas e externas. São compostas pelos equipas diferentes. Também o tamanho de eventos são em geral diferentes que devem refletir nos seus orçamentos.

[130 - dança, concorreu mas nunca teve apoio]

66 Penso que será importante separar os concursos, porque penso as estruturas de programação "absorvem" uma parte significativa dos apoios relativamente às de criação. Seria mais equilibrado.

[132 - artes plásticas, concorreu mas nunca teve apoio]

66 No meu entender, deviam ser elaborados concursos distintos pois as motivações, os processos de produção e os objectivos artísticos finais são diferentes.

[135 - cruzamentos disciplinares, nunca concorreu]

66 Somos de opinião que os apoios devem ser separados - porque correspondem a políticas distintas de apoio, uma em que se apoia os artistas na criação, outra que apoia uma política de animação para um local ou período de tempo.

[157 - cruzamentos disciplinares, nunca concorreu]

66 Sim, concordo com a separação conforme programa de 2016. Valorizamos o ato de criação e por isso deve ter o seu próprio espaço concorrencial para avaliação. No entanto, sublinhamos a importância da correlação criação vs circulação-programação como fatores determinantes no apoio.

[177 - música, concorreu mas nunca teve apoio]

6 Penso que deveriam ser separados, uma vez que a actividade de criação artística é independente da de programação e venda de espectáculos. 0 processo deverá estar separado do resultado, mas ter em vista a facilidade de contactos com entidades que possam facilitar a programação. Por exemplo, uma entidade que não possua verbas e pessoas para se dedicarem à venda de espectáculos, mas com alto potencial de criação de espectáculos deveria ter oportunidades semelhantes a outras entidades que possuem esse departamento ou conhecimentos. Para um artista é uma sobrecarga muito grande ter de programar os seus espectáculos, apesar de essa ser a realidade actual em muitos dos artistas que conheço que foram financiados.

[193 - música, nunca concorreu]

6 Penso que seria vantajoso separar as modalidades nos concursos uma vez que os critérios de avaliação seriam diferenciados o que permitiria melhor avaliar 
as diferentes modalidades. Seria igualmente importante diferenciar os formulários de candidatura. Já fiz candidaturas a projectos de criação e senti um profundo desajustamento no formulário cujas perguntas são por vezes impossíveis de responder no momento em que a criação ainda não existe.

[205 - artes digitais, teve apoio]

6

Os Apoios Pontuais deverão ser separados em Apoios à Criação, Programação e Edição, sendo que uma entidade poderá concorrer aos três. Os apoios Anuais, Bianuais e Quadrienais deverão acontecer nos mesmo moldes, sendo que as entidades escolhem qual a tipologia onde se inserem (criação, programação ou mistas). Estes projetos/entidades têm uma responsabilidade maior nas comunidades onde se inserem e os limites das suas ações são mais ténues do que nos projetos pontuais. Um apoio $A, B$ ou $Q$ apoia em grande medida a estrutura, a sua lógica de atuação e o projeto a concurso, enquanto que um apoio Pontual, apoia em exclusivo o projeto.

[286 - teatro, teve apoio]

64 Não conhecemos as opções de 2016, no entanto consideramos absolutamente necessário separar os concursos tendo em conta as diferenças estruturais dos diferentes projectos a concurso. Fundamentação: Em linhas gerais existem vários modelos de estruturas, no interior de um mesmo sector: companhias de repertório que, pela natureza dos seus objectivos - apresentam regularmente vários espectáculos durante temporadas de um ano cada -, exigem uma estrutura de longa duração que comporte um elenco de artistas concatenados através de práticas técnicas e artísticas capazes de responder, coerentemente e em conjunto, aos seus processos criativos e à linha artística que as identifica esteticamente. Este é um trabalho de longa duração e é o seu objectivo final. Outras estruturas há, cujos objectivos propoem um conjunto de actividades adjacentes ao modelo anterior como, por exemplo: workshops, aulas de técnicas, residências artísticas, e mesmo criação de espectáculos para os quais contratam artístas por períodos intermitentes e que, esgotadas essas actividades voltam à estaca zero. Fazer coabitar, no mesmo ponto de partida, estruturas com objectivos e orientações artísticas tão diversas, é um contra-senso bem plasmado nos anteriores concursos e que seria um grande erro repetir.

[287 - dança, teve apoio]

66 Separar em concursos diferentes. Fundamentação: $\underline{\text { A concorrência parece mais }}$ justa pois os projetos serão avaliados e apreciados respeitando as especificidades e exigências de cada área, de forma mais rigorosa.

[331 - arquitetura, teve apoio] 
64 Devem ser apoios distintos. São critérios de avaliação diferentes. A lógica de um concurso de apoio à criação deveria obedecer a critérios meramente artísticos. No caso da programação estão em causa, além de critérios artísticos, outro tipo de critérios como, a tipologia do espaço que gere, públicos-alvo, serviço educativo, formação de públicos, etc. A separação destas verbas permite, ainda, obter uma visão mais clara da forma como estamos a estruturar o sector e a apoiar a actividade artística nacional. Dado que a actividade de programação decorre da existência de criadores, são estes devem ser priorizados num sistema de atribuição de apoios às artes, no sentido de lhes serem facilitadas as condições para criar e para poderem mostrar os seus objectos artísticos aos mais diversos públicos, isto é, serem programados.

[370 - teatro, teve apoio]

66

Devem ser separados. Embora haja entidades com vocação mista (programação e criação) outras têm uma especificidade, ... Quando os concursos são demasiado abrangentes a atribuição de classificação das respostas é perigosa. As estruturas que se dedicam a apenas uma das atividades são obrigadas a repensar os projetos em função dos concursos e não dos seus objetivos artísticos. Se uma estrutura apenas se dedica à criação ficará automaticamente prejudicada em concursos sem separação, segundo o modelo antigo.

[371 - teatro, teve apoio]

6

Duas únicas modalidades: criação e programação. que é um programador? Grosso modo, a entidade, com espaço próprio, que organiza, contrata (e paga) espectáculos de natureza vária. Há-os de dois tipos diferentes: singulares ou colectivos, associações, cooperativas, empresários em nome individual... e que gerem espaços públicos; e as autarquias (que podem ou não ter directores artísticos para os seus teatros municipais), centros culturais, mas todos da esfera pública. $O$ apertado crivo de selecção das candidaturas a par da redução dos apoios à criação, obrigou os criadores a tornarem-se 'programadores'. $\underline{0}$ que hoje se verifica é que a programação mais não é do que 'acolhimentos', 'residências'... cabendo às autarquias a responsabilidade do pagamento de cachets e demais custos. Seria de todo o interesse que, para distinguir claramente a criação/produção da programação se realizassem dois concursos separados. Deve, no entanto, salvaguardar-se a possibilidade de as entidades, desejandoo, incluírem na sua programação de criação/produção, actividades que com esta, directamente, se relacionem.

[461 - teatro, teve apoio] 


\section{Condicional}

Entre as entidades que defendem a separação dos concursos detetam-se algumas condições que estas entidades consideram dever ser satisfeitas: a possibilidade de uma mesma entidade concorrer aos vários concursos com diferentes projetos (condição defendida por uns, mas rejeitada por outros).

Sugere-se ainda a criação de apoios complementares específicos, designadamente: apoios à produção, apoios à criação experimental, apoios diretos aos artistas individuais e apoios às estruturas de programação regular (espaços situados fora dos centros urbanos de Lisboa e Porto).

6

Idealmente deveriam ser concursos separados mas sem a limitação da exclusão pela gestão de projetos em curso já subsidiados pela DGA, ex: uma entidade que promove criação já subsidiada poder candidatar-se a programação sempre que não exista sobreposição (financeira e programática) e vice versa. De outra forma seria limitador e estrangularia o raio de ação das entidades. Não sendo possível deverá ser um concurso único para manter a diversidade dos planos.

[154 - outra área, teve apoio]

66 Os apoios devem ser separados. No entanto é importante garantir que tanto um como o outro são altamente controlados quer no número de público REAL que consegue, quer nos objetivos e dinamicas que pretendem. Será extremamente importante que um não dependa do outro mas que se complementem com um controlo muito elevado. No caso dos apoios à programação deve existir abertura obrigatória de espaço para novos e romper com os ciclos. Também deve ser reduzido os valores possíveis com o número de vezes que conseguiu subsidio. Não Faz qualquer sentido que entidades ou criadores sejam constantemente apoiados financeiramente num período superior a 3 anos. Se em 3 anos com apoio não conseguiram criar público e estrutura para se tornarem mais independentes não deverá ser o estado a continuar a subsidiar por inteiro as suas criações egocêntricas. Têm que existir uma clara responsabilidade e controlo.

[164 - dança, nunca concorreu]

6f Julgamos que é importante separar os dois concursos. É contudo importante verificar as dotações orçamentais de cada um. No nosso caso, entidade de criação, julgamos que a quantidade de projectos de criação apoiados no concurso de 2016 foi claramente insuficiente. Há que definir muito bem o que se considera criação e o que se considera programação.

[210 - música, teve apoio] 
66 [...] Sim, devem ser separados os apoios e também distinguir projectos de experimentação pontual.

[217 - teatro, teve apoio]

66 Do nosso ponto de vista, pode ajudar a manter a clareza dos critérios de seleção, bom como poderá ser um contributo positivo para a concretização de uma avaliação mais justa, a separação das 2 tipologias de atividade. É certo que existem estruturas que acumulam ambas as funções, mas parece-nos menos confuso e que suscite menos dúvidas nas metodologias de apreciação das candidaturas se os concursos forem apresentados em separado. Acrescentamos ainda uma tipologia que nos diz respeito diretamente, e que temos como provar que é essencial para o sucesso dos projetos de criação artística nacional, que é a do "Apoio à Produção". Existem [...] pequenas estruturas nacionais de Apoio à Produção artística nacional que também não poderão sobreviver e garantir a continuidade de sua ação sem uma intervenção direta do Estado Português e que não têm sido contempladas nas modalidades de apoio. [...] Estruturas estas que não têm qualquer capacidade financeira para pagarem pelos serviços de produção que necessitam. Para que se consiga elevar o grau de profissionalização da forma como a criação artística acontece (tanto do ponto de vista da reunião das condições básicas como do ponto de vista da concretização da oferta cultural, na forma como chega ao grande público) é necessário todo um trabalho de produção que os criadores artísticos, sózinhos, não conseguem executar. Assim sendo, a criação de uma terceira modalidade de apoio, que seja destinada a estruturas de apoio à produção artística parece-nos essencial e urgente.

[248 - teatro, concorreu mas nunca teve apoio]

66 Faz sentido a separação APENAS se os apoios à programação não se sobrepuserem e vierem a substituir os apoios directos aos artistas pois isso só acentuará o privilégio de uns em detrimento de outros artistas. Os programadores são gatekeepers que abrem possibilidades a uns e não a outros. Isso faz parte do seu trabalho. Mas o excesso de poder dos programadores pode atrofiar e condicionar a criação artística da pior forma.

[174 - cruzamentos disciplinares, nunca concorreu]

6 Apesar de sermos uma estrutura mista de criação e programação (já que temos o nosso próprio teatro e dinamizamos 2 salas de espectáculo), parece-nos que em termos concursais se deveriam distinguir claramente as 2 áreas, por serem objectivamente diferenciáveis. Por outro lado, o actual modelo, que atribui pontuação valorativa ao acolhimento/ programação, não permite quantificar/ determinar qual orçamento está disponível para programação.

[284 - teatro, teve apoio] 
6 Para nós é muito importante a separação dos concursos. Consideramo necessário a criação de uma concurso específico para estruturas de programação regular, dirigido exclusivamente aos espaços situados fora dos centros urbanos de Lisboa e Porto. Este apoio, a ocorrer, permitiria equilibrar o financiamento entre a oferta e a procura. A existência de um concurso teria por si só a capacidade de gerar uma dinâmica de mérito nas políticas de programação e promover a colaboração entre estruturas e projetos, tornando mais exigente a articulação entre Estado, municípios e demais entidades tutelares dos espaços de programação. De um modo sumário, o concurso deveria complementar as modalidades de apoio direcionadas para a criação já existentes no contexto da DGArtes.

[413 - cruzamentos disciplinares, teve apoio]

66 Os apoios à criação e à programação, do nosso ponto de vista, deverão ser separados, à semelhança dos apoios pontuais de 2016. Desta forma haverá um melhor enquadramento dos projectos a concurso, garantindo-se assim uma avaliação comparativa mais justa, para além de assegurar um processo concursal menos confuso. Esta separação, traduzida em eventuais concursos, deverá salvaguardar três aspectos que nos parecem fundamentais: 1. Garantir a possibilidade de os Apoios à Criação preverem actividades de programação de âmbito complementar, que neste caso deverão ser apreciadas e avaliadas apenas como factores de majoração, e vice-versa, ou seja, garantir a possibilidade de os Apoios à Programação preverem actividades de criação de âmbito complementar, apreciados e avaliados como factores de majoração; 2 . Garantindo o ponto anterior, não permitir o apoio simultâneo de uma entidade aos Apoios à Criação e aos Apoios à Programação. 3. Permitir os Apoios à Programação apenas às entidades de criação e produção artística de carácter profissional, excluindo-se candidaturas apresentadas exclusivamente por entidades de acoIhimento (por exemplo, Teatros Nacionais e Municipais), podendo no entanto estas mesmas candidaturas serem valorizadas e majoradas quando apresentadas em parceria entre entidades de criação e produção, e entidades de acolhimento.

[494 - teatro, teve apoio]

6

Do ponto de vista desta entidade os Concursos devem ser separados no seu âmbito Criação ou Programação, sendo que uma mesma entidade deverá poder concorrer a ambos os concursos em paralelo. Ex.: Uma entidade de Criação não deve estar no mesmo âmbito de Concurso de um Festival. Os objectivos de uma Criação Artística ou de uma Programação são distintos e pontualmente antagónicos e esta separação é essencial ao desenvolvimento pleno destas actividades.

[37 - teatro, teve apoio] 
46 Os apoios à criação e à programação deveriam ser atribuídos em concursos separados, não obstante muitas vezes coexistirem. Mais importante do que separar a criação da programação, seria separar apoios individuais dos apoios a associações, porque os indivíduos são sempre prejudicados nas avaliações, uma vez que não têm um estrutura de apoio solidificada.

[25 - arquitetura, concorreu mas nunca teve apoio]

\section{Depende}

Como referido anteriormente, $5 \%$ das entidades apresentam argumentos a favor de uma e outra opção (manter o concurso único ou separar os concursos de criação e de programação). É bastante evocada a necessidade de coexistência dos dois tipos de concursos: concursos únicos para entidades mistas e concursos separados para entidades de criação e para entidades de programação. Argumenta-se que desta forma é possível ir ao encontro das características seminais das entidades artísticas.

Outro dos posicionamentos detetados prende-se com as modalidades de apoio, havendo entidades a defenderem concursos únicos para os apoios plurianuais e concursos separados para os apoios pontuais.

66 Esta é matéria que apresenta algum grau de complexidade e exige reflexão aprofundada mas, em síntese: pensamos que tecnicamente a solução mais adequada, até para que o Estado afirme a sua independência, será atender a três possibilidades: Criação, Programação e Mista. Assim, cada concursante terá a liberdade de decidir em que campo, ou campos, assume a sua acção. Saliente-se, porém, que, no caso da modalidade Mista, em sede de candidatura deverá estar claramente definido o que constitui Criação e o que constitui Programação. Isto, mesmo em termos orçamentais.

[427 - teatro, teve apoio]

6 Do nosso ponto de vista, uma entidade mista, que programe e crie, prepara o seu plano de atividades tendo em conta as duas modalidades. Parece-nos que os apoios poderiam contemplar as duas modalidades num mesmo concurso, 0 que evitaria as entidades concorrerem a mais do que um concurso. Para além disso, os apoios poderiam ser atribuído mediante o tipo de entidades, nomeadamente, as entidades que são mistas, as que são apenas de criação e as que são de programação.

[178 - teatro, nunca concorreu] 
6 A [nossa entidade], tal como diversas estruturas semelhantes, é uma entidade que se dedica tanto à criação como à programação, e como tal uma modalidade mista é para nós essencial. No entanto concordamos que de uma forma geral o apoio à criação não deve ser confundido com o apoio à programação, e a sua separação pode ajudar a um financiamento mais justo de ambas as partes. Mas uma vez que a separação completa de ambos pode ser difícil, uma solução possível podia ser a criação de 3 alinhas (criação/programação/mistos) ou a atribuição de percentagens de esforço para ambas as partes nos casos de candidaturas em concursos conjuntos. Mas a nossa opinião sincera é que o apoio destinado à criação não deveria ter de competir com os apoios à divulgação e difusão das entidades de programação, nem deveria ter de competir com os apoios para a estrutura, como o pagamento de salários e custos fixos de cada entidade. $\mathrm{O}$ apoio à criação deveria ser sempre protegido, pois esta a base para a existência de entidades de programação e de estruturas fixas. 0 apoio à criação não deveria também estar submetido aos mesmos critérios de valorização de publico que um apoio de programação, pois no primeiro o mais importante é a sua relevância artística para os criadores, e no segundo a sua capacidade de gerar momentos de relevância cultural para o público, o que são objectivos completamente diferentes, que geram percursos de trabalho e resultados destintos.

[114 - artes plásticas, teve apoio]

66 A [nossa] visão é a de que a criação e a programação são atividades, por definição, diferentes, que no entanto podem complementar-se e fazer parte de um mesmo projeto (sobretudo, a médio e a longo prazo). Entendemos que talvez possa ser uma opção as entidades definirem o seu percurso como A: criação / B: programação / C: criação + programação, porque isso facilita a definição da identidade do projeto. Assim sendo, dar-se-ia lugar a três formas diferentes de concurso.

[343 - teatro, nunca concorreu]

66 Para as entidades que desenvolvem actividade de Criação e Programação deve existir apenas um concurso porque muitas vezes as actividades estão relacionadas e fazem parte de um projectos geral. Para as entidades que fazem só programação, o concurso deve ser outro e deve ter uma dotação financeira específica porque a natureza dos projectos destas entidades que só programam são muito distintos das entidades que criam e programam.

[377 - teatro, teve apoio]

66 Se por "programação" se entende colocar em circulação o objeto artístico resultante do "apoio à criação" eu acredito que se deveria sempre complementar a criação apoiada com apoio imediato para sua subsequente programação, pois é por demais comum que as criações sejam vistas por um par de dias e pouco mais, isso quando não vão diretamente para a prateleira após a estreia. 
Por outro lado há sempre criações já em repertório que beneficiariam de apoio apenas para programação. No nosso caso, não tendo espaço de apresentação, necessitarmos recorrer aos espaços de acolhimento, que por sua vez tem cada vez menos recursos para comprar eventos. Se. como entidades criadoras, tivermos apoio para cobrir custos básicos de digressão (logística e/ou caches para criadores e intérpretes) teremos nós condições de oferecer produtos para que sejam programados por entidades de acolhimento. Assim, um concurso para criação deveria sempre incluir uma razoável programação, de preferência circulando pelo país, mas se poderia manter a alternativa de concorrer isoladamente a apoios apenas para programação de peças que já estejam em repertório. Isso porque as entidades de acolhimento tem cada vez menos meios para suportar custos de programas, e é extremamente raro se conseguir que as receitas de bilheteira dessas apresentações quase pontuais, cubram despesas e pagamentos de caches e serviços.

[162 - cruzamentos disciplinares, concorreu mas nunca teve apoio]

6 A divisão de apoios poderá trazer maior adequação à avaliação de entidades cuja actividade é fundamentalmente diferente. No entanto, cremos que a maioria das entidades existentes são na verdade mistas, fruto do desenvolvimento do próprio sector, o que significa, numa divisão de concursos, penalizar o acesso a determinada actividade em detrimento de outra ou, a poder concorrer a ambas, a pesar nas estruturas do ponto de vista administrativo. Por outro lado, a divisão em apenas criação e programação deixa de fora áreas fundamentais e características do sector, como: formação, investigação e difusão, actividades a que muitas entidades se dedicam significativamente e, nalguns casos, quase exclusivamente. Assim, uma divisão não deve reduzir o sector a apenas essas actividades (reduzindo-o a uma dinâmica oferta/ procura), por não o representar mas antes empobrecer, nem deve ser factor impeditivo de acesso a financiamento adequado à complexidade e dimensão de muitas estruturas existentes no presente.

[376 - dança, teve apoio]

66 Pensamos que o melhor será possibilitar a opção por uma de 3 tipologias: criação, programação ou mista. Isto permitiria que a entidade fizesse a sua escoIha de acordo com a natureza da sua atividade. Os montantes disponíveis para cada tipologia não devem ser pré-definidos, mas decididos de acordo com o número e as características das candidaturas apresentadas.

[476 - cruzamentos disciplinares, teve apoio]

6 A haver uma separação por tipologia seria necessário criar três concursos prevendo as actuais tipologias em vigor - Entidades de Criação, Entidades de Programação e Entidades Mistas - salvaguardando as entidades que desenvolvem planos de actividades verdadeiramente mistos e às quais seria difícil optarem 
por uma das áreas (criação ou programação), enquanto área dominante. A criação de um concurso para Entidades Mistas pretende evitar que a mesma entidade tenha que se candidatar a mais do que um concurso para ver apoiado o seu plano de actividades na totalidade, o que na realidade resultaria numa multiplicação de processos burocráticos ainda superior ao verificado com apenas um concurso, o que é incomportável para a dimensão geral das estruturas profissionais nacionais. Contudo, os projectos devem ser avaliados e compreendido em todas as suas valências e vertentes, segundo os mesmos critérios de avaliação gerais definidos e os objectivos do apoio consignados na lei e regulamento que o regulam. A Criação e a Programação são actividades complementares, e embora se desenvolvam de formas diferentes com recursos diferentes, são idênticas em termos dos objectivos gerais que perseguem, dentro do enquadramento destes concursos. Exceptuam-se ao aqui referido os factores de majoração que poderiam beneficiar de uma separação por tipologia já que uns estão naturalmente mais enquadrados no ADN das actividades de programação e outros das de criação.

[481 - dança, teve apoio]

6 No caso dos Pontuais acreditamos que o concurso deve ser distinto já que as atividades são distintas, com tempos, objetivos e apoios diferentes. Já nos anual, bienais ou quadrienais deve estar tudo junto, ou seja, o concurso deve ser por entidade e todas as atividades que essa entidade abrange.

[70 - outra área, teve apoio]

66 Os apoios à criação e à programação, devem ser atribuídos em concursos diferentes. Pensamos que o apoio à criação deve ser privilegiado nos concursos pontuais e os de programação devem ser atribuídos nos anuais e plurianuais. O próprio carácter subjacente a estes concursos aponta para esta conclusão, ou seja, os apoios pontuais devem ter como objecto estruturas que pela sua natureza e/ou condições de trabalho, como sejam ausência de espaço próprio, dificuldades e incertezas de orçamento, pouca visibilidade pública, etc, não Ihes permitam ter um trabalho continuado e uma programação vasta e definida, e os anuais e plurianuais, gradativamente, para as estruturas que tenham possibilidades físicas e artísticas de manterem uma programação estável e programável. De referir que preferíamos a utilização da nomenclatura no apoio a estruturas em lugar de apoio a programação.

[454 - teatro, concorreu mas nunca teve apoio] 


\section{Áreas artísticas objeto de apoio}

Partindo do elenco das áreas artísticas apoiadas pela DGArtes (arquitetura, design, artes digitais, artes plásticas, fotografia, música, dança, teatro e cruzamentos disciplinares), perguntava-se às entidades se seria mais adequado alargar, manter ou restringir este leque de áreas artísticas.

Para além destas 3 opções de resposta (resposta múltipla) solicitava-se a nomeação das áreas a restringir ou a alargar bem como a respetiva fundamentação ${ }^{30}$.

Quanto às 3 opções de resposta (gráfico 15), a maioria das entidades (66\%) considera que as atuais áreas artísticas se devem manter; um pouco mais de um quarto considera que os apoios se devem alargar a outras áreas (26\%) e apenas $10 \%$ considera que deve haver uma restrição das áreas objeto de apoio.

\section{Gráfico 15. Áreas artísticas objeto de apoio}

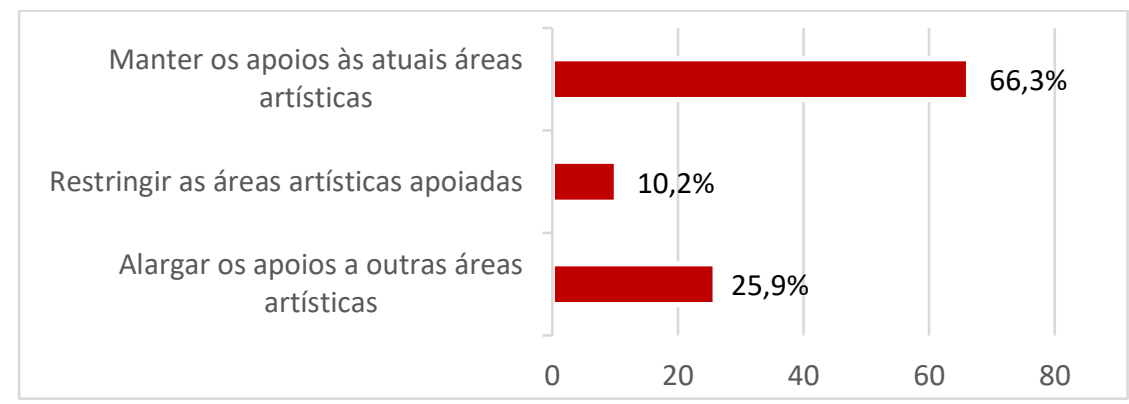

Fonte: CIES-IUL, EPEA, 2017.

Nota: pergunta de resposta múltipla.

Para uma parte substancial das entidades inquiridas, a explicitação do posicionamento sobre o leque de áreas artísticas a apoiar é geralmente precedida por uma ressalva de que esta decisão é uma medida de política cultural uma vez que é ao Estado (e não às entidades artísticas) que cabe definir quais as áreas a apoiar e é necessário a afetação de meios financeiros adequados.

\footnotetext{
${ }^{30}$ Q13. No que diz respeito ao leque atual de áreas artísticas apoiadas pela DGArtes (arquitetura, design, artes digitais, artes plásticas, fotografia, música, dança, teatro, cruzamentos disciplinares), considera mais adequado: Manter os apoios às atuais áreas artísticas; Restringir as áreas artísticas apoiadas. (Indique as áreas artísticas cujo apoio seria de manter); Alargar os apoios a outras áreas artísticas. (Identifique as outras áreas artísticas a apoiar). Por favor fundamente a resposta. A taxa de resposta é $98 \%$.
} 
6 Os apoios devem ser alargados de acordo com um plano de política cultural a longo prazo que seja sensível à inovação e evolução da prática artística.

[241 - teatro, teve apoio]

66 Esta é para nós uma questão de política cultural e, por isso, entendo que cabe ao Estado decidir quais as áreas que deve restringir ou apoiar e em que moldes.

[287 - dança, teve apoio]

66 Não julgamos caber-nos a nós uma fundamentação que venha a considerar mais pertinentes ou com mais necessidade de apoios umas áreas em detrimento de outras.

[297 - música, teve apoio]

66 Esta questão só se coloca, e não há resposta adequada nem à pergunta nem às soluções apontadas porque não há por parte do Estado a visão da importância da Arte e em consequência não há dotação orçamental adequada ao apoio às Artes fundamentada ao tecido artístico nacional.

[398 - música, teve apoio]

66

Sem capacidade económica nenhum alargamento ou restrição fará a diferença.

[186 - teatro, teve apoio]

6

Qualquer das áreas atualmente apoiadas integram a realidade e a diversidade de atuações que caraterizam o desenvolvimento cultural nacional. Por isso, qualquer exclusão só poderá decorrer pela existência de um quadro específico de candidatura que o justifique, tal como acontece na área da produção cinematográfica. O problema é que a exiguidade do montante global para o apoio às artes tem sido francamente exíguo para a atividade que tem permitido uma dinamização significativa da vida cultural do país. É urgente uma dotação orçamental mais significativa para o Ministério da Cultura, não confinando apenas o apoio às artes à verba inscrita no Orçamento Geral do Estado. A articulação com outras áreas ministeriais e com programas específicos de apoio resultantes de parcerias do Ministério da Cultura com outros organismos privados nacionais e internacionais.

[260 - cruzamentos disciplinares, teve apoio]

6 A grande questão não é o número de categorias abrangidas mas sim os apoios atribuídos a cada uma delas. Parece-nos que tem existido um aumento no apoio a companhias/entidades de teatro mas para as outras áreas, nomeadamente na dança, o valor não aumentou. $\mathrm{O}$ que deverá ser claro é a quando do 
lançamento das candidaturas ser divulgado os montantes para cada área, se continuarem a ter diferenças tão grandes. $O$ ideal será que a política de apoio seja clara e justa: não desvalorizar áreas artísticas em prol de outras.

[265 - dança, teve apoio]

\section{Manter os apoios às atuais áreas artísticas}

Centrando a questão no âmbito das políticas públicas para a cultura, algumas entidades salientam a importância de o Estado assegurar o apoio a expressões artísticas mais desprotegidas (face ao mercado).

6 acreditamos que as áreas que actualmente são abrangidas são as que devem ter o apoio do Estdado ainda que se deva atender às especificidades de cada proposta excluindo as que tenham caris comercial. ex: festivais de música apoiados por marcas comerciais.

[485 - cruzamentos disciplinares, teve apoio]

66 Julgamos que, acima de tudo, os apoios devem continuar a ser direccionados para áreas e projectos de criação e programação cuja viabilidade comercial não esteja, de todo, ligada à sua qualidade e pertinência artística e social e que demonstrem, assim, necessitar deste tipo de apoios para florescer.

[297 - música, teve apoio]

66 Estas parecem-me abranger um leque bastante alargado de actividades. Deve no entanto ter-se em conta a dinâmica de cada uma das áreas e estar atento à sua transformação e nascimento de novas áreas artísticas, não deixando nenhuma de fora dos concursos.

[437 - teatro, teve apoio]

Evocam-se ainda princípios de equidade e diversidade de expressões artísticas, bem como se refere a importância de assegurar a estabilidade/regularidade na abertura dos concursos.

64 Pensamos que dentro das áreas neste momento disponíveis ainda existe muito trabalho a fazer ao nível da equidade entre elas, dos níveis de apoio, na relevância do desequilibro nas oportunidades e na oferta de projetos

[282 - música, nunca concorreu] 
66 As oportunidades devem ser iguais para todos, ou pelo menos justas. Deveria-se ainda criar um apoio a projetos destinados a apoiar estes mesmos artistas, nas mais variadas áreas, assim quem não conseguir o apoio por parte da DGArtes, terá a ajuda/apoio por parte destes outros projetos e este dinheiro diretamente reverte para os artistas, para que a arte seja feita.

[51- artes plásticas, nunca concorreu]

66 embora se perceba que algumas [entidades] estejam mais habituadas a recorrer aos apoios governamentais (como é o caso do Teatro, Dança e Cruzamentos Disciplinares) e outras recorram menos. No entanto, parece-me fazer parte da obrigação estatal a criação de linhas de apoio destinadas a todas elas, preferencialmente, em programas separados e distintos.

[248 - teatro, concorreu mas nunca teve apoio]

Em alguns depoimentos recolhidos, as entidades traçam a evolução da estrutura organizacional dos serviços da tutela responsáveis pelo apoio às artes para justificar o leque de áreas artísticas que, desde 2006, está contemplado no regulamento.

66 O apoio do Estado faz sentido para o desenvolvimento de todas as áreas artísticas actualmente contempladas nos apoios. A centralização num só orga$\underline{\text { nismo, }}$ que tutela genericamente o apoio às "Artes" é algo que questionamos.

[425 - dança, teve apoio]

66 Talvez esta diversidades de áreas se explique por a dada altura ter havida uma fusão entre o Instituto das Artes e o Instituto Arte contemporânea com a criação da Direç̧ão Geral das Artes, mas parece evidente que esta fusão pouco inclui entidades cuja actuação é essencialmente nestas áreas e que se vêm subjugadas a um modelo de apoio e respectivos mecanismos menos adequados à sua natureza.

[481 - dança, teve apoio]

66 Todas estas áreas artísticas devem ser apoiadas, ainda que não obrigatoriamente pela mesma instituição, já que têm lógica de funcionamento muito distintas. Foi uma opção política extinguir o IAC [Instituto de Arte Contemporânea], por exemplo, há alguns anos, e os apoios às artes plásticas transitaram para a DGArtes, que por sua vez tem origem no IA e, mais remotamente, no 
Instituto Português das Artes do Espectáculo. Trata-se portanto de uma discussão sobre a orgânica do Ministério da Cultura e que ultrapassa a questão do modelo de apoio às artes.

[498 - teatro, teve apoio]

66 Enquanto que o IPAE foi uma instituição de apoio às artes do espectáculo, a DGArtes, pela sua definição, deverá relacionar-se com, e apoiar o maior número possível de áreas artísticas.

[283 - teatro, teve apoio]

A área dos cruzamentos disciplinares é objeto de posicionamentos extremos. Por um lado, defende-se que esta tem sido o recurso utilizado para a representação de algumas áreas artísticas (sobretudo as emergentes e/ou não enquadráveis nas existentes).

6 Penso que a abrangência dos apoios é suficiente pois permite a inclusão de outras áreas através dos cruzamentos disciplinares.

[258 - artes plásticas, nunca concorreu]

6 Parece me abrangente, graças o CRUZAMENTOS DISCIPLINARES que permitem por os projetos de fusão.

[173 - cruzamentos disciplinares, concorreu mas nunca teve apoio]

6 Tb a necessidade dos "cruzamentos disciplinares" nos parece inquestionável na conjuntura contemporânea, uma vez que boa parte da produção cultural não encaixa nas subdivisões anteriores, mais clássicas, mas caracteriza-se pelas formas mais variadas de hibridez, miscigenação, ambiguidade... entre o desenho e o vídeo, o pensamento e o sensível, etc.

[416 - cruzamentos disciplinares, teve apoio]

Por outro, é criticada a excessiva abrangência da área de cruzamentos disciplinares, sendo por isso apontada a necessidade de uma melhor definição.

66 A definição dada de cruzamentos disciplinares ("O encontro e a relação entre diferentes disciplinas artísticas, na criação e na programação, incluindo intersecções com as ciências e as tecnologias") parece um melting pot onde cabem 
vários projectos, tendo em conta, por exemplo, as tendências contemporâneas da dança ou do teatro.

[289 - cruzamentos disciplinares, teve apoio]

66 A opção "Cruzamentos Disciplinares" é demasiado abrangente e poderia ser restringido o apoio porque os projectos irão sempre ter uma área artística predominante, ou seja, aquela que engloba maior número de dependentes/intervenientes apoiados.

[66 - música, nunca concorreu]

6 As áreas artísticas tendem a multiplicar-se em sub-categorias que com o tempo se tornam em novas áreas artísticas. Será desejável uma simplificação das áreas artísticas periódica. Será que os Cruzamentos Disciplinares se justificam numa época em que as diferentes áreas já se misturam naturalmente com regularidade em diferentes graus de interdisciplinariedade?

[247 - teatro, teve apoio]

É também questionada a pertinência da área de cruzamentos disciplinares numa época em que as diferentes áreas artísticas se misturam em diferentes graus de interdisciplinaridade e quando os projetos artísticos acabam sempre por ter uma área artística predominante.

6 As áreas artísticas correspondem às formas de arte.Excluir algumas não faz sentido, pois equivaleria a excluir totalmente uma forma de arte dos apoios do Estado ostracizando-a. Há-que haver lugar à pluralidade. Por outro lado, o cruzamento disciplinar fica bastante empobrecido sem recurso a várias fontes de inspiração.

[457 - teatro, teve apoio]

6 Compreende-se uma vontade de garantir uma pluralidade de apresentação de propostas artísticas. Contudo as áreas fundem-se, multiplicam-se e movimentam-se, não sendo, a nosso ver, relevante para a avaliação do projecto a área onde se inscreve. É redutor a classificação por áreas estanques numa época caracterizada não só pela miscigenação, mas pela inovação procurando uma visão mais abrangente da contemporaneidade.

[388 - cruzamentos disciplinares, teve apoio]

Ainda que defendendo a manutenção do leque de áreas artísticas, algumas entidades propõem formas alternativas de as "arrumar" em grandes grupos. 
66

Devem manter-se os apoios às atuais áreas artísticas, mas separar as áreas performativas (música, teatro, dança e respetivos cruzamentos) das plásticas (e respetivos cruzamentos).

[259 - cruzamentos disciplinares, teve apoio]

66 Pensamos que em nenhum caso as áreas artísticas deverão ser reduzidas a não ser que sejam reagrupadas segundo um novo critério. Também pensamos que seria interessante existir algum tipo de equilíbrio entre as diferentes áreas uma vez que no nosso caso, pensamos que a Arquitectura acaba por ter sempre menor percentagem de apoio. É certe que a arquitectura vive com um pé na técnica e outra na Arte, mas esta é a única modalidade de apoio que existe actualmente e pensamos que, por vezes,, é vista como secundária perante o restante corpo das ARTES.

[34 - arquitetura, concorreu mas nunca teve apoio]

6 Outra opção poderia ser a hierarquização das áreas, porque se mistura meios com campos disciplinares. A Fotografia é uma arte em si, mas é um meio de outras áreas, como o design, as artes digitais..., que não seria necessário mencionar. Nesses casos o projecto é cruzamento disciplinar? Mas se a fotografia é instrumental? ... Nesta segunda opção penso que poderia ser interessante separar A - Arquitectura, Design, Artes Plásticas, Música, Teatro, Dança, Cinema e depois dentro de cada uma destas áreas maiores listar opções mais específicas Por exemplo: A "criação" "programação" ou "pesquisa" no campo de A - Design irá cruzar que áreas: B - Equipamento, Gráfico, Interiores, Moda, Instalação, Fotografia, Pintura, Escultura, Performance, Video, Artes Digitais, Animação, Som.

[171 - design, concorreu mas nunca teve apoio]

6

Para mim, a categoria "Artes Digitais" não faz sentido, por considerar que as suas actividades estão contempladas na família do "Design" (desenho, ilustração e pintura digital/vectorial, pixel art, animação digital... no meu entender, são sub-áreas do Design Gráfico/de Comunicação)

[135 - cruzamentos disciplinares, nunca concorreu]

6 Sugiro um novo modelo que deverá ter por base não as áreas artísticas apoiadas pela DGArtes, mas os (novos) campos de intervenção no qual aquelas se inserem e os objectivos a que se propõem com os seus projetos. Tal modelo, acredito, poderá garantir uma menor percentagem de iniquidades, assim como a oportunidade de maior abrangência dos projetos a apoiar, podendo resultar na promoção, maior protagonismo e relevância de cada uma das áreas culturais para a sociedade portuguesa.

[478 - cruzamentos disciplinares, concorreu mas nunca teve apoio] 
6 Se por um lado entendo que se devem manter os apoios a estas diferentes áreas artísticas, por outro, penso que devia haver grupos gerais que pudessem incluir as diferentes artes. Os grupos deviam ser: Música, Dança, Teatro e Outras Artes. Dentro destas deviam haver outras divisões por exemplo: Música Criação, Programação, Interpretação, Cruzamentos disciplinares; Dança: Criação, Programação, Interpretação, Cruzamentos disciplinares; Teatro: Criação, Programação, Interpretação, Cruzamentos disciplinares; Outras Artes: as restantes áreas e as especificidades de cada uma de acordo com os objetivos do programa.

[42 - música, teve apoio]

66 Uma lógica diferente poderia permitir reagrupar as cinco primeiras áreas numa só, criando um território onde o Estado poderia partilhar o investimento com a Economia. Na verdade, estas áreas (em especial algumas delas) estão muito imbricadas na actividade económica e a investigação e o conhecimento que produzem são directamente absorvidas por ela. Um programa criativo seria capaz de atrair este investimento e alargar os plafonds disponíveis. O que aconteceu como tendência da última década e meia foi o alargamento das áreas atiradas para o mesmo saco, isto é, o mesmo orçamento. Sendo que, ainda assim, esse orçamento foi sofrendo sucessivos cortes.

[498 - teatro, teve apoio]

\section{Restringir as áreas artísticas apoiadas}

Os posicionamentos que defendem a restrição de áreas artísticas (10\% das entidades inquiridas) são diferenciados.

Um deles defende que os apoios da DGArtes devem ser direcionados às artes performativas e que para as restantes áreas deve ser definido um novo enquadramento legal, com regulamentos e tipologias de apoio específicos.

66 Apoiar apenas as artes performativas não implica menosprezar as restantes artes, mas, em termos de concurso, parece mais fácil e mais trasnparente apoiar apenas aquelas, estabelecendo outras oportunidades para as restantes artes.

$$
\text { [344 - música, nunca concorreu] }
$$

6 A natureza e as características de cada actividade deveriam ditar se deve ou não existir apoio do Estado a essa actividade. Os casos da arquitectura e design, por exemplo, parece-nos suficientemente distintos das artes performativas para dificilmente serem englobados nos mesmos concursos (sendo que mesmo 
as diferentes artes performativas têm características distintas umas das outras e deveriam ser alvo de concursos diferenciados).

[528 - teatro, concorreu mas nunca teve apoio]

6 Arquitectura, Design e Artes digitais enquadram-se num universo particular, a merecer um tratamento adequado e distinto, convocando outros organismos/entidades para suportar as medidas de apoio.

[189 - teatro, teve apoio]

6 São universos artísticos que precisam de tipos diferentes de apoio, Uns precisam apoio para distribuir seus objetos à venda, precisam apoio para salvaguardar seus direitos e remuneração nas vendas, apesar dos inúmeros intermediários que esses mercados implicam. Outros precisam apoio para produzir seus espetáculos e juntar seus apreciadores num espaço limitado e por um brevíssimo período de tempo para usufruir do espetáculo que tem para mostrar. É um momento breve que nem sempre se consegue cumprir, $\underline{A}$ fragilidade da situação efémera não pode competir com as necessidades específicas das expressões das artes visuais, e merecem ter uma atenção dedicada e especializada.

[162 - cruzamentos disciplinares, concorreu mas nunca teve apoio]

Um outro posicionamento defende, de forma radical, a exclusão do apoio à arquitetura e ao design, justificando que estas áreas têm "funcionalidade" e "rentabilidade" que não justificam o apoio por parte do Estado.

6 A arquitectura e o design só muito especialmente tem uma expressão artística tout cour e quando se expõe usa meios das outras áreas artísticas: fotografia, artes digitais, artes plásticas.

[508 - artes digitais, teve apoio]

6 As actividades de arquitectura e design, apesar de serem cirativas servem fins lucrativos (imobiliario e marketing) que pela sua natureza da actividade tem um publico mais vasto e consumidor dos seus eventos. Logo tem uma capacidade de gerar despesas e receitas muito maiores. Portanto não deveriam poder concorrer a fundos publicos nos moldes actuais. Por exemplo a Trienal de Arquitectura gera despesas e receitas que mais nenhum outro projecto em portugal consegue

$$
\text { [208 - artes plásticas, nunca concorreu] }
$$


6 Em relação à arquitectura e ao design não são arte, podem passar a ser em alguns casos mas à partida não o são, são contrucções/criações com uma finalidade própria que não é a arte pela arte.

[480 - música, teve apoio]

6 atribuição de apoios públicos a estas áreas artísticas prende-se com o facto de as mesmas constituírem bens públicos, promotores de mudanças de pensamento na organização das sociedades e na vivência em comunidade. Falamos de objetos que não têm como objetivo a sua rentabilização financeira, mas um valor não quantificável, e que por isso não conseguiriam sobreviver sem um apoio por parte do Estado. Por este motivo, a Arquitetura e o Design são casos especiais, que deverão ser analisados pontualmente, quando os projetos desenvolvidos ao abrigo destas modalidades tiverem um interesse manifestamente artístico e não comercial.

[273 - teatro, teve apoio]

Algumas entidades defendem a existência de concursos com regras adaptadas à especificidade de cada área.

6 Um concurso que inclui áreas tão díspares como as atuais tem resultados necessariamente injustos, na medida em que se compara o incomparável: objeto, processo criativo, produção, equipas. Os critérios de seleção e avaliação de projetos não podem ser comuns a artes performativas e artes visuais ou plásticas, podendo e devendo estas ser apoiadas através de apoios e concursos próprios

[424 - música, teve apoio]

66 mas os concursos deveriam ser organizados de acordo com a natureza das próprias actividades artísticas e o contexto/mercado em que se desenvolvem. Assim, faria sentido organizar os concursos em três secções distintas - artes performativas, artes visuais e cruzamentos disciplinares -, respondendo cada secção às especificidades das actividades artísticas em questão.

[213 - teatro, teve apoio]

66 [...] cada área artística deveria ter um concurso específico para a sua área de maneira a que, por exemplo, o Teatro não esteja a concorrer de modo directo com a Arquitectura ou outra área artística completamente distinta. Seria um concurso mais justo: os projectos de Teatro a concorrer com projectos de Teatro; Dança com Dança; e assim sucessivamente. E ainda uma distinção de concursos para consolidados e para emergentes, pois actualmente as condições 
de produção (espaço de trabalho, circulação, co-produções, apoios financeiros...) são bastante desvantajosas para as estruturas emergentes, logo levam desvantagem ao concorrerem directamente (de igual para igual) com estruturas consolidadas que beneficiam de melhores condições e oportunidades.

[489 - cruzamentos disciplinares, teve apoio]

\section{Alargar os apoios a outras áreas artísticas}

Quanto ao alargamento dos apoios a outras áreas artísticas, defendido por $26 \%$ das entidades inquiridas, como referido anteriormente, este abrange uma multiplicidade de domínios culturais tal como fica patente na análise do quadro 7.

\section{Quadro 7. Alargamento do apoio a outras áreas artísticas por domínio cultural}

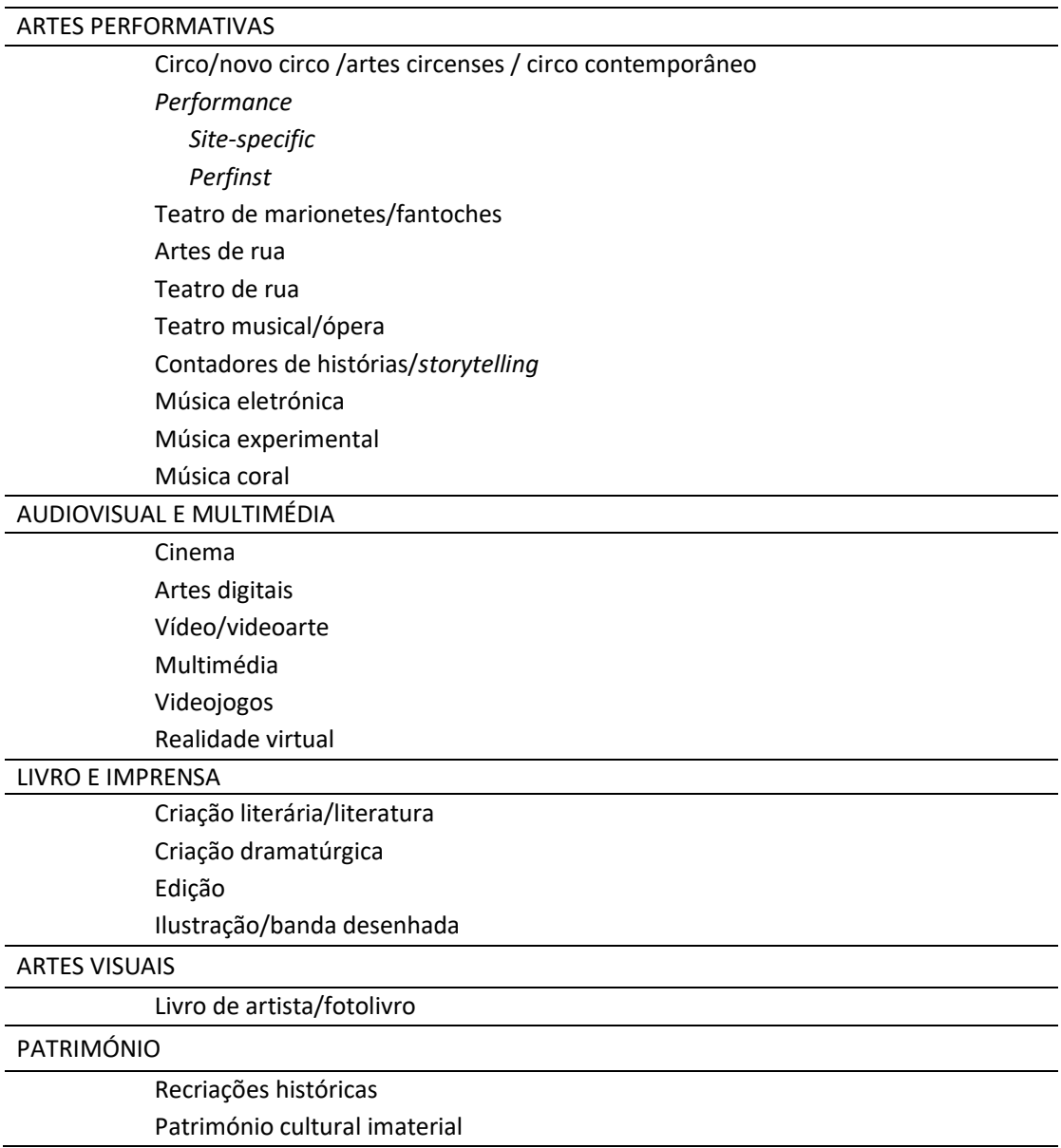


(...)

OUTROS DOMÍNIOS

Novos géneros artísticos

Arte urbana/arte pública

Arte comunitária

Design de moda

Curadoria

Fonte: CIES-IUL, EPEA, 2017.

Nota: para a sistematização das áreas artísticas elencadas nas respostas das entidades seguiu-se a classificação ESSNET das atividades artísticas por domínios culturais (Bina et al., 2012).

Nota: não foram incluídos dados quantitativos de forma a não quebrar a confidencialidade das respostas.

As áreas artísticas sugeridas nem sempre correspondem à(s) da(s) entidade(s) que a(s) propõe $(m)$. E se há casos em que a sugestão provém de entidades que atuam numa área nunca contemplada no modelo de apoio às artes (e que por isso nunca puderam concorrer aos referidos apoios), noutros casos provém de entidades candidatas e/ou beneficiárias dos apoios da DGArtes em áreas devidamente previstas nos regulamentos de apoio.

66 Atendendo às particularidades do sub-setor Artes de Rua/Circo, ao potencial desta área à escala europeia e à situação climatérica, turística e de utilização do espaço público para fins artísticos em Portugal, cremos que o reforço estruturado e ponderado desta área como um sub-setor definido e como uma área específica de definição poderá potenciar o desenvolvimento e estruturação de novas entidades a trabalhar numa área com potencial de crescimento.

[165 - outra área, nunca concorreu]

66 O Novo Circo é uma área bastante desenvolvida nalguns países da Europa e em franco desenvolvimento noutros. Em Portugal têm tido lugar, nos últimos 15 anos, algumas iniciativas e programas de estímulo ao desenvolvimento desta área, seja na programação de espectáculos internacionais por algumas estruturas de programação, seja na coprodução de espectáculos de companhias nacionais (cerca 3/4 profissionalizadas e localizadas no norte do país), ou através de workshops pontuais na área da técnica circense. Recentemente surgiu no país, um centro de formação especializado nesta área - INAC - na Maia. Nenhuma das companhias de Novo Circo em Portugal é financiada pelo governo e sobrevivem graças às parcas possibilidades de coprodução ou através de projectos de animação de rua, encomendados normalmente pelos municípios. Os artistas portugueses nesta área têm praticamente todos formação superior em escolas internacionais, vão fazendo cursos de aperfeiçoamento no estrangeiro e muitos não regressam a Portugal por falta de oportunidade [...]. O Novo Circo é transversal a todas as áreas performativas resultando em espectáculos muito exigentes ao nível da técnica mas com forte carga poética, visual e estética. A 
prática da técnica circense tem atraído cada vez mais jovens à sua aprendizagem e em casos específicos tem cumprido funções de inclusão social: no trabalho com jovens em risco. Apesar do potencial desta área e dos esforços pontuais no que toca ao seu desenvolvimento em Portugal, conclui-se que um apoio específico para a área é preponderante para se desenvolver um trabalho estruturado e contínuo, com efeitos visíveis junto do público, da fixação de profissionais no país e de um trabalho e rede ao nível internacional.

[413 - cruzamentos disciplinares, teve apoio]

66 As artes circenses são uma área com a sua especificidade e características próprias e com potencial de crescimento. Neste momento existem no país escolas de formação de profissionais da área, parece-me portanto estarem reunidas as condições e necessidades para que passem a ser considerados nos apoios.

[242 - teatro, nunca concorreu]

64 As áreas de expressão artística como as Artes de Rua, o Circo Contemporâneo e a criação em Site -Specific, são portadoras de um léxico próprio e de condições próprias no âmbito do apoio à criação bem como no apoio à circulação das obras. Deverão ter um enquadramento próprio que conserve as suas especificidades como a questão sazonal.

[486 - outra área, nunca concorreu]

66 As artes de rua e as artes circenses têm vindo a originar nos últimos tempos zonas de criação com maior expressão nas nossas comunidades. Para tal, torna-se necessário que sejam regulamentadas e ordenadas. A abertura de linhas de financiamento para estas áreas permitiria organizar estas áreas, fornecendo-Ihes um contexto de atuação.

[410 - teatro, teve apoio]

6 Projectos que se enquadram no que se tem vindo a denominar de "performance arte" ficam sem enquadramento óbvio para uma candidatura pois serão facilmente prejudicados na área do teatro, da dança, ou dos cruzamentos disciplinares. E parece que a missão da dgartes é igualmente proteger formas de expressão artística desprotegidas e em emergência no país. Daí a proposta para alargar à performance arte. Por outro lado, dentreo de cada área deveria ser protegida a diversidade de géneros.

[289 - cruzamentos disciplinares, teve apoio]

6 [...] Excluir disciplinas que surgiram durante o século XX [Performance, Site specific, Videoarte, Perfinstl e são tangentes às práticas artísticas que a DGArtes já reconhece é uma forma de elitismo pouco salutar para uma organização que se pretende ser das artes, e não apenas de algumas. Não incluir estas novas 
áreas pode levar à ilusão de que, das duas uma, ou elas não têm expressão em Portugal, ou, por outro lado, criar a ficção de que se apoiam X projetos de Teatro (por exemplo), quanto na realidade esses projetos são não teatrais, mas sim de performance.

[343 - teatro, nunca concorreu]

66 A Performance e a llustração/Arte Urbana são duas áreas com crescimento acentuado na ultima década, que não se distinguem correctamente nesta distribuição. Se as Artes Digitais, que são ainda um campo novo, se destacam, então também estas áreas deveriam ser reconhecidas.

[114 - artes plásticas, teve apoio]

66 A especificidade deste tipo de teatro [teatro de marionetas] requer tempos e meios muito diferentes dos institucionalizados para o teatro de actor. estruturalmente as organizações de teatro de marionetas são compostas maioritariamente por pessoas polivalentes onde os próprios marionetistas(executantes ) são os criadores, encenadores etc. sendo todo o processo de candidatura aplicado a uma formula de estrutura convencional muitas vezes não se consegue justificar no projecto esta polivalência.

[364 - teatro, teve apoio]

66 Lisboa e Portugal são a capital e país europeus que menos produzem ópera. A Ópera é a forma de arte performativa mais transdisciplinar por excelência, por isso é designada de forma de arte total, reúne todas as outras.O repertório português operático ao longo do tempo não está editado, nem gravado, nem disponível e o Ministério de Cultura nada exige à única casa de ópera portuguesa,Teatro Nacional de São Carlos, obrigações no sentido da preservação do património operático português, nem noutros sentidos vitais [...] . A ópera esgota os teatros sempre que é apresentada. Existe grande procura e sede de ópera por parte do público português.Existe uma ignorância generalizada face a este género no nosso país, já que a maioria dos programadores e directores artísticos dos principais teatros e Instituições culturais portugueses vêm maioritariamente do teatro e dança e para além de desconhecerem completamente o universo da ópera, não têm interesse e revelam mesmo preconceito.Posto isto acho fundamental que a ópera seja considerada nestes concursos como uma área independente da música, pois deve ser incentivada de forma assumida e com cotas no número de projecto a apoiar. O Teatro e dança têm sido muito favorecidos,

[373 - teatro, teve apoio]

66 Os apoios à música parecem restringidos ao jazz e música clássica. No entanto, Portugal é muito forte no que diz respeito à chamada música experimental.

[83 - cruzamentos disciplinares, teve apoio] 
66 A arte pública não é pública só porque está ao ar livre ,é pública porque é uma manifestação de actividades artísticas e estratégias que utilizam o público como a génese e o tema para analisar. É pública por causa do género de questões levantadas ou postas, e não pela sua acessibilidade ou número de espectadores. Numa clara inversão da desassociação dos públicos com a obra de arte pública surgem cada vez mais projectos de arte comunitária.

[463 - teatro, teve apoio]

6 [O Cinema] é uma área em grande expansão actualmente em Portugal, com bons nomes emergentes no panorama internacional, e que necessita de mais apoio.

[88 - outra área, nunca concorreu]

66 O multimédia e a videoart têm vindo a ter um preponderante papel na criação de conteúdos artísticos e o ICAM é algo limitado nesse assunto.

[452 - teatro, nunca concorreu]

6 Dada a expressão que a Vídeo Arte tem na produção artística global e consequentemente também na produção artística nacional, e em função da disseminação e da importância própria do vídeo como forma de expressão artística, parece-me fundamental que esta passe a ser uma área artística específica.

[436 - música, teve apoio]

6 Videojogos têm mérito para ser considerados uma área artística isolada. Cabe à DGArtes fomentar o desenvolvimento cultural de videojogos artísticos em Portugal, e elevar a fasquia para este tipo de criações em Portugal. $O$ apoio de instituições como a DGArtes é fundamental para desenvolver projectos que não têm necessariamente cariz comercial, mas que exploram e avançam a cultura da humanidade

[185 - outra área, nunca concorreu]

64 Portugal tem uma forte cultura literária e por isso não se deve perder essa distinção e ela deverá ser um exemplo para se poder apoiar os autores existentes e os novos, para a criação de novas prosas, poesias, dramaturgias, romances, entre outros

$$
\text { [509 - teatro, concorreu mas nunca teve apoio] }
$$


66 Todas as área importantes parecem estar representadas, no entanto a literatura não pode ser esquecida pois é uma área de criação muito importante. Se apoiam tradução porque não a criação obras originais?

[331 - arquitetura, teve apoio]

66 [...] A [entidade] tem, quer no âmbito da Criação, quer no da Programação dado atenção à dramaturgia nacional. No âmbito da Criação, em particular, vários têm sido os autores contemporâneos que a Companhia tem levado à cena [...]. Lançou mesmo um concurso para a criação de texto dramático [...]. E porque não nos temos dado mal com estas abordagens, pensamos que seria oportuno valorizar/incentivar a criação de literatura dramática nacional com um programa adequado. É importante vincar o estímulo à criação de Literatura Dramática nacional.

[427 - teatro, teve apoio]

6 Consideramos que uma estratégia de apoio às artes deve explicitar todas as vertentes da cultura. A área da promoção do livro e da leitura deveria ser contemplada tendo em vista estimular agentes culturais, na área da programação, a promover iniciativas idênticas àquelas que tipicamente estão reservadas a bibliotecas, livrarias, editores, autarquias, de entre outras, tais como festivais literários, comunidades de leitores, sessões com escritores, etc.

[232 - música, teve apoio]

66 A edição de livros/discos, etc. cuja finalidade não é apenas comercial ou promocional mas sim que promove uma assinatura autoral forte, uma reflexão sobre a contemporaneidade e a história, e a experimentação artística. A publicação de livros/discos com lógicas de edição comparáveis à obras de arte é fundamental para a inscrição da arte contemporânea na história da arte em Portugal bem como para a promoção à nível nacional e internacional das obras dos criadores nacionais (ou que residem em Portugal).

[211 - outra área, teve apoio]

66 [Alargamento à Banda Desenhada e llustração porque] Apesar do carácter funcional que o desenho possa ter nestas áreas - desenhar um argumento ou iluminar um texto - parece que se podia quebrar esse ciclo de raciocínio quando os trabalhos são mais experimentais e gráficos.

[59 - outra área, nunca concorreu]

66 No domínio da produção artística na fotografia, alem dos modelos de apresentação e valorização usuais, está a ser cada vez mais significativa uma transferência de produção pelo suporta editorial. O Fotolivro é hoje uma das grandes 
apostas na produção artística fotográfica. Pela sua versatilidade, capacidade de circulação e a forma como consegue alcançar novo publico. Por esta razão, acrescentava uma área artística: a edição / Livro de artista

[295 - fotografia, nunca concorreu]

66 O conceito e área de actividade Património Cultural Imaterial baseia-se na Convenção da UNESCO para a Salvaguarda do $\mathrm{PCl}$ (2003, ratificada e transcrita em lei em Portugal em 2008) e engloba os dominios ARTES PERFORMATIVAS (teatro, dança, música) e EXPRESSÕES ORAIS. [...] Uma actividade continuada de criadores/performers (a maioria com formação superior em teatro ou letras) que estão a conseguir a renovação da arte narrativa em Portugal. Estes profissionais trabalham e cativam públicos para a arte da palavra dita (e do gesto e da música e da gestão do tempo cénico) deste o primeiro ciclo até à terceira idade, dentro e fora de ambientes institucionais. A eles devemos cada vez mais. Num país que está a secar a sua fonte vital, a cultura partilhada, eles retomam a renovação da língua, das narrativas, da imaginação, da criatividade, prosseguindo uma tradição que nos deu Gil Vicente, Camões e o Judeu... poderia estender a lista até artistas contemporâneos apenas friso a posição cultural nuclear desta(s) arte(s). Resta relembrar que a narração oral ofereceu à humanidade grande parte das obras literárias fundadoras das culturas ocidental e oriental.

[49 - outra área, teve apoio]

64 As áreas artísticas que concorrem são as que, regra geral, estão mais fragilizadas ou requerem apoio permanente estatal mas por vezes projetos de recriação histórica ficam "na gaveta" por falta de orçamento anulando a celebração da identidade de Portugal através dessa mesma recriação de momentos ou manifestações que fazem parte da nossa História.

[176 - teatro, concorreu mas nunca teve apoio]

Para além de áreas artísticas são referidos outros eixos de apoio, considerados relevantes pelos agentes inquiridos. 
Quadro 8. Outros eixos de apoio sugeridos pelas entidades

\section{OUTROS EIXOS DE APOIO}

Investigação/pesquisa artística

Formação e qualificação

Mediação cultural

Participação comunitária

Serviços educativos/formação de públicos

Equipamentos e espaços culturais

Articulação entre arte e educação

Fonte: CIES-IUL, EPEA, 2017.

66 É fundamental criar uma linha de apoio a projectos de Investigação Artística que não se centrem necessariamente numa área artística específica, que não se reflictam forçosamente na criação de um espectáculo, mostra ou exposição, que possam versar teoria, registo, edição, documentação, pesquisa de campo, transmissão de conhecimento e troca de experiência. Que embora alicerçados num pensamento e numa linha, enquadrados numa metodologia, fundamentados, possam acolher o imprevisto e o imediato, reagir ao quotidiano, responder ao minuto exacto. Que permitam, como na Ciência, que se experimente errando, para se encontrar. Igualmente se deve apoiar o Registo e a Documentação enquanto área autónoma, a fim de poder resguardar e sistematizar passados, preservar objectos e documentos, trabalhar materiais, criar Arquivos tão dinâmicos quanto possível e que, por um lado funcionem como pólos-museu tão estáticos e organizados quanto possível, por outro possam ser húmus de novas criações e investigações, espalhando pontos de partida e inspirando; enfim, contrariando a efemeridade que a maioria das Artes, sobretudo as performativas, protagonizam. Um conceito como o de Perfinst que investigamos, ou uma peça de Teatro que se escreva, um romance, uma partitura que se crie - precisa de ser editado para ser valorado, alargado, difundido.

[487 - outra área, teve apoio]

66 Acredito que é fundamental existir apoios de pesquisa de indole artistica, que permitam creativos que despender um periodo de tempo (minimo de 3 meses a um maximo de $1 \backslash 2$ ano) a pesquisar sobre uma tematica que seja relevante ao país. Esta pesquisa poderá ser quer no territorio nacional ou internacional, caso justificavel.

[183 - cruzamentos disciplinares, teve apoio] 
66 Muitas entidades culturais, incluindo a nossa associação, promovem workshops, conferências e programas formativos específicos para a profissionalização do sector da música, que são fundamentais para que o sector se torne sustentável, e que encontram larga procura por parte de artistas em início de carreira. Estas ofertas formativas não existem no ensino formal e, ao serem apoiadas, potenciariam muito o desenvolvimento de carreiras artísticas de sucesso.

[203 - música, teve apoio]

64 Consideramos importante o investimento nesta área [Artes Comunitárias] que está inserida nas várias tipologias mas merece um apoio especial para os projectos desta natureza. $\mathrm{O}$ crescimento deste sector e a procura crescente por projectos comunitários já permite a abertura desta tipologia.

[440 - dança, teve apoio]

66

Para as características que o nosso colectivo apresenta (envolvimento da comunidade num exercício de exploração vocal e corporal) não identificámos nenhuma modalidade de apoio que seja adequada à nossa realidade, a não ser no apoio na criação de apresentações multidisciplinares. A nossa actividade como agentes de promoção de cultura e auto afirmação através da arte não são um factor reconhecido para além de um ou outro ponto de avaliação.

$$
\text { [74 - outra área, concorreu mas nunca teve apoio] }
$$

6 Até ao momento o serviço educativo e a formação tinham de ser incluídos nos cruzamentos disciplinares, mas na verdade, deveriam ser considerados uma área por si mesmas. A formação de públicos sensibilizados para as artes, através de serviço educativo e formações para as artes são a única forma de garantir que os futuros projectos apresentados terão de facto um público preparado para compreender o que está a assistir, seja isto um espectáculo de teatro ou dança, um concerto de música ou uma exposição de pintura, entre outras. Neste momento não sabemos se de facto, tendo em conta a importância da formação de públicos, o serviço educativo deveria ter um apoio da DGARTES separado dos restantes apoios.

[406 - outra área, concorreu mas nunca teve apoio] 


\section{Distribuição das despesas a considerar nos apoios}

Sobre o tipo de despesas a considerar nos apoios procurou-se recolher contributos sobre a forma mais adequada de distribuir o apoio financeiro entre atividades e estrutura. Na formulação da pergunta ${ }^{31}$ inclui-se um conjunto de questões que sugerem várias possíveis opções de resposta. Estas opções constituem o núcleo central da codificação (gráfico 16). Na fundamentação da resposta, a grande maioria das entidades situa-se por referência às opções propostas no enunciado da questão. Algumas há que divergem, ou porque em geral se situam fora do quadro do apoio às artes (aqui codificado como "Opinião difusa", 5\%) ou porque apresentam argumentos para duas ou mais opções de resposta (código "Depende"), e que aliás constitui um posicionamento com um peso significativo (17\%).

\section{Gráfico 16. Distribuição dos apoios entre atividades e estrutura}

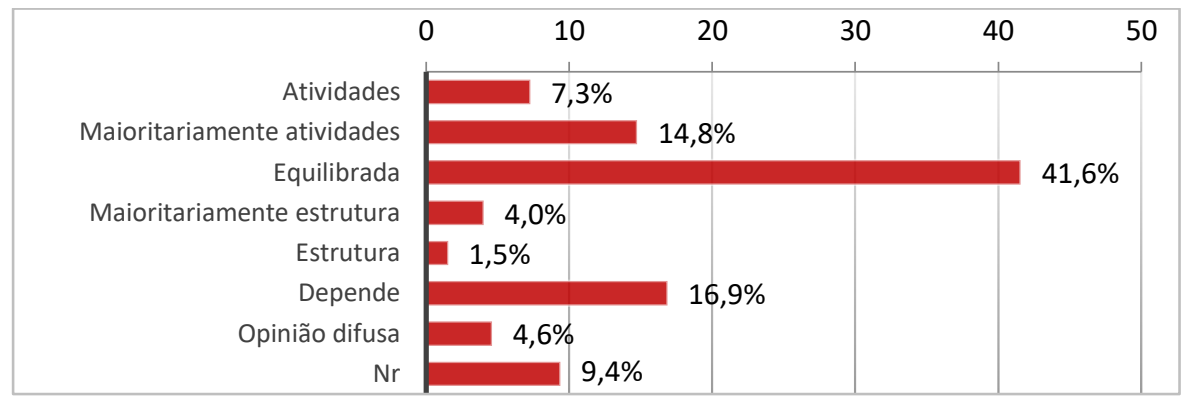

$(n=522)$

Fonte: CIES-IUL, EPEA, 2017.

Nota: codificação exclusiva.

O posicionamento mais frequente consiste em considerar atividades e estrutura de forma equilibrada (42\%). As despesas com atividades (maioritária ou equilibradamente face às despesas de estrutura) recolhem a parte substancial

\footnotetext{
${ }^{31}$ Q14. Uma das questões que tem sido colocada refere-se ao tipo de despesas a considerar nos apoios, designadamente àquelas que se referem à estrutura organizacional. Do ponto de vista da entidade, qual seria a forma mais adequada de distribuir o apoio financeiro entre as componentes referentes às atividades e à estrutura: Apenas para atividades? Atividades e estrutura, mas maioritariamente atividades? Atividades e estrutura de forma equilibrada? Atividades e estrutura, mas maioritariamente estrutura? Apenas para estrutura? Por favor fundamente a resposta. A taxa de resposta é $91 \%$.
} 
dos posicionamentos ( $64 \%$ no seu conjunto). As posições que defendem que os apoios devem ser canalizados para a estrutura (maioritária ou exclusivamente) recolhem $6 \%$. Vários posicionamentos relativizam a sua opção (17\%), considerando que o balanço entre atividades e estrutura depende do tipo de apoio em causa (da modalidade, do domínio...).

De um modo geral são aduzidos argumentos que relacionam os apoios pelas duas componentes com a modalidade de apoio ou, num outro plano, com a articulação entre os financiamentos da administração central (tendencialmente para atividades) e local (tendencialmente para estrutura). São feitas diversas considerações sobre a necessidade de não esgotar os apoios nas atividades, mas de considerar igualmente a estrutura, até no sentido em que estas podem ganhar capacidade de captação de outros apoios financeiros. Verifica-se uma associação frequente entre posições que defendem o apoio à estrutura e a redução da precariedade, com a profissionalização (e não apenas dos artistas) e sustentabilidade do sector, mesmo quando a posição se inclina para uma distribuição equilibrada entre atividades e estrutura.

\section{Apenas para atividades}

Os posicionamentos que defendem que os apoios devem ser apenas para atividades associam frequentemente estas e criação (e a entidades do domínio da criação) e aos artistas e têm origem em parte significativa em entidades de menor dimensão (medida pelo orçamento de 2016) e com uma relação de menor proximidade com o modelo (nunca concorreu ou concorreu, mas nunca teve apoio).

6 A meu ver este dinheiro deveria ser distribuído diretamente para os artistas, atividades e para gastos inerentes aos projetos, bem como produção. As entidades deveriam ser capazes de gerir e garantir as suas próprias receitas através dos eventos/atividades que desenvolvem com este apoio/financiamento. Assim o dinheiro das artes é usado efetivamente para as artes e não para manter associativismo que nada, ou pouco fazem, para garantir o sucesso e lucro dos seus eventos.

[51 - artes plásticas, nunca concorreu]

6 Apenas para actividades, na maior parte dos casos, dado ser entidade singular. [475 - artes plásticas, nunca concorreu] 
66 Do ponto de vista desta entidade, a resposta seria atividades, já que não envolve estruturas físicas e/ou logísticas complexas.

[111 - música, teve apoio]

66 Mais actividades obrigando as estruturas a procurar também outras fontes pois quanto mais apoios forem distribuídos maior será a reciprocidade de procura e de interesse.

[26 - dança, concorreu mas nunca teve apoio]

6 Apenas para as actividades, as estruturas devem manter-se por elas próprias !

[85 - dança, teve apoio]

66 Tenho alguma dificuldade em responder a esta questão. Não consigo enquadrar aqui, neste questionário, a dita estrutura na relação com a criação artística. Portanto, diria "apenas para actividades".

[6 - fotografia, nunca concorreu]

66 No nosso entender só para actividades, pois a estrutura deve ter formas de se auto-sustentar, caso contrário não pode ter futuro! Deve procurar obter receitas para estrutura através do mecenato empresarial, sócios, actividades, etc..

[23 - música, concorreu mas nunca teve apoio]

66 Apenas para a actividade, pois parece-nos que o orçamento para a mesma, deve contemplar todas as necessidades para a sua apresentação.

[168 - música, teve apoio]

66 Apenas atividades. Somos da opinião de que não deve haver acumulação de apoios. Ou atividade ou estrutura.

[256 - teatro, teve apoio]

66 Apenas para atividades. A existência de uma estrutura de criação só faz sentido ao serviço das respetivas atividades.

[429 - teatro, teve apoio] 
66 Atento o exposto, distribuições financeiras para apoio a estruturas deverão ficar a cargo de entidades locais, isto é, próximas e, assim, conhecedoras, quiçá em primeira mão, do trabalho das estruturas apoiadas.

[433 - teatro, teve apoio]

\section{Maioritariamente para atividades}

Os posicionamentos que se situam do ponto de vista de uma distribuição maioritariamente para as atividades fazem-no por entenderem que isso garante a diversidade de atividades e que estas podem ser fonte de receitas. Consideram também que o essencial nos apoios é a criação (e são sobretudo entidades do domínio da criação). Entre os argumentos mobilizados consideram também que a estrutura organizacional já existe (e tem/deve ter outros financiamentos). Tipicamente, quando é quantificado o que se entende por maioritariamente, isso significa até $20 \%$ para a estrutura.

6 Actividades e estrutura, mas maioritariamente actividades. Sem estrutura uma organização não pode funcionar, no entanto quando a estrutura recebe um apoio igual ou superior às actividades, algo parece estar desequilibrado.

$$
\text { [34 - arquitetura, concorreu mas nunca teve apoio] }
$$

66 Atividades e estrutura, mas maioritariamente atividades, pois já temos uma estrutura estabelecida

$$
\text { [48 - artes plásticas, nunca concorreu] }
$$

6 Atividades e estrutura, mas maioritariamente atividades. Desta forma as atividades teriam que, de alguma forma, ajudar a gerar recursos para a manutenção da estrutura aspecto que poderia ser benéfico na formação de públicos.

$$
\text { [72 - dança, nunca concorreu] }
$$

66 "Atividades e estrutura, mas maioritariamente atividades" (com a ressalva de que não temos experiência de subsídios). $O$ investimento nas atividades é mais visível para o público, desta forma beneficiando a população mais directamente, mas o investimento na estrutura permite criar autonomia e assim reduzir a dependência de subsídios no futuro.

$$
\text { [41 - música, nunca concorreu] }
$$


6 Atividades e estrutura, sendo que maioritariamente para a vertente atividades. A estrutura tem outras formas de se auto financiar mas as atividades não. Alias, as atividades podem ser uma fonte financeira da estrutura.

$$
\text { [82 - teatro, nunca concorreu] }
$$

66 Actividades e estrutura mas maioritariamente actividades São as actividades que geram essencialmente receitas ou é devido a estas que se sustenta uma estrutura. Com uma equipa fixa de elementos que garanta o funcionamentobase será possível aumentar ou diminuir a estrutura com colaboradores externos, havendo assim períodos de maior intensidade e complexidade que dão lugar a outros onde a actividade tem um cariz diverso. Esta flexibilidade não é, contudo, rígida ou líquida dado os cenários e as necessidades de muitas estruturas serem díspares.

[426 - teatro, teve apoio]

\section{Distribuição equilibrada}

Aqueles que defendem a distribuição equilibrada dos apoios consideram que isso constitui uma garantia do funcionamento normal, o que por sua vez pode permitir a angariação de parcerias e financiamentos noutras fontes. É defendido também que deve incluir todas as despesas inerentes aos projetos. Do conjunto dos contributos resulta que equilibrada não significa necessariamente 50\%-50\%. São igualmente aduzidos argumentos de que essa distribuição facilita a profissionalização das entidades e que pode constituir um garante de manutenção das atividades/projetos.

66

Devem ser apoiadas as atividades e a estrutura de forma equilibrada. A generalidade das associações não tem estruturas organizadas e isso reflete-se na falta de capacidade técnica a nivel da organização, promoção, marketing e criação de publicos. O Estado deveria incentivar uma profissionalização das estruturas, como forma de motivar o desenvolvimento de um terceiro setor sustentável a médio prazo.

[201 - artes digitais, nunca concorreu]

66 Atividades e estrutura de forma equilibrada seria a melhor opção uma vez que a estrutura necessita de financiamento para poder angariar apoios extra para as atividades. Esse trabalho de angariação de apoios extra DGArtes e de desenvolvimento de parcerias é uma trabalho altamente qualificado, que requer tempo para ter sucesso, e isso implica ter recursos qualificados. Por vezes é 
muito dificil conseguir este equilíbrio: não há dinheiro para se procurar dinheiro.

$$
\text { [205 - artes digitais, teve apoio] }
$$

66 Atividades e estrutura.existe despesas que não estão contidas nas atividades como salários e infraestrutura, documentos fiscais

$$
\text { [207 - artes plásticas, teve apoio] }
$$

6 A forma mais adequada sera perceber que se ha uma estrutura significa que funciona 12 meses e não só no período de apresentação de trabalho. Isto aplica se as varias areas de criação. Não são lojas que abrem 5 dias a semana o ano todo. Ha periodos de preparação e de apresentação. Logo deve ser equilibrado entre a estrutura e as actividades. No fundo a estrutura mantem e prolonga as actividades por isso deve ser tida em conta, mas repito de forma equilibrada.

$$
\text { [208 - artes plásticas, nunca concorreu] }
$$

6 Acho que a atividade não funciona corretamente sem uma boa estrutura por isso o apoio deve ser equivalente entre as duas areas

[439 - outra área, concorreu mas nunca teve apoio]

6 O apoio financeiro deve ser para a estrutura e atividades, porque para manter e apoiar as atividades a estrutura necessita de um fundo de maneio que permita manter a estrutura a funcionar para assim desenvolver as atividades a que se propõe.

[298 - outra área, concorreu mas nunca teve apoio]

66 A forma mais adequada de distribuir o apoio financeiro seria actividades e estrutura de forma equilibrada. É importante o financiamento das despesas com estrutura pois assim torna-se possível que a estrutura aumente a sua capacidade de gestão e consolidação caminhando para formas mais independentes de financiamentos às suas actividades. Obviamente, que o apoio às actividades é importantíssimo e vital permitindo às entidades atingir de forma imparcial objectivos como: criar Arte e não entretenimento; acesso democratizado a espectáculos; arte e serviço público; descentralização da Arte.

[489 - cruzamentos disciplinares, teve apoio]

66 Atividades e estrutura de forma equilibrada. A autonomia artística, administrativa e de gestão ficará melhor salvaguardada com uma partilha do financiamento entre o Estado central e os Municípios.

[413 - cruzamentos disciplinares, teve apoio] 
G6 É essencial procurar-se um equilíbrio entre programação/ criação de atividades e a viabilização de uma estrutura de continuidade e profissionalizada. Neste sentido a distribuição de financiamento por ambos os componentes permitiria a consolidação de condições para as equipas de trabalho, reforçando a viabilização de uma programação de qualidade.

[246 - cruzamentos disciplinares, concorreu mas nunca teve apoio]

6 Proponho um modelo de apoio às atividades e à estrutura de forma equilibrada, ou seja por exemplo incluir uma percentagem no apoio às actividades de despesas relativas à entidade numa parcela de despesas da estrutura no orçamento, que possa ir até $15 \%$ do valor total do mesmo. Á semelhança do que acontece nos orçamentos do instituto do cinema (ICA) - ver Diário da República, 2.a série - N. $037-23$ de fevereiro de 2016. Regulamento n.ㅇ 186/2016: Artigo 4. Encargos gerais 1 - Os encargos gerais de estrutura da entidade beneficiária são considerados como despesas elegíveis quando forem imputáveis ao projeto e apenas até ao limite máximo de $15 \%$ do valor do apoio financeiro do ICA. 2 - Os encargos gerais da estrutura são os encargos necessários à prossecução da atividade do beneficiário e que são comuns a vários projetos. 3 - Poderão ser enquadrados na categoria de encargos gerais de estrutura, nomeadamente os seguintes tipos de despesa: a) Consumos de energia; b) Água; c) Comunicações; d) Apoio informático; e) Manutenção de equipamento; f) Limpeza, segurança e vigilância; g) Seguros associados à estrutura; h) Combustíveis; i) Documentação técnica; j) Rendas das instalações; k) Aquisição de serviços externos de contabilidade, jurídicos e outros; I) Pessoal administrativo; m) Depreciações de equipamento desde que suportadas pela fatura de aquisição do mesmo e o mapa fiscal de amortizações, e na proporção da utilização do equipamento para a concretização do projeto; n) Outras despesas administrativas e consumíveis (como por exemplo, provisões, perdas com transações cambiais, custos associados à elaboração do projeto de candidatura).

[393 - cruzamentos disciplinares, nunca concorreu]

66

As atividades só poderão ter lugar se a estrutura tiver um apoio financeiro sustentável, com trabalhadores salariados, de modo que o equilíbrio entre estrutura e atividades deve ser baseado na prática, ou seja, no tamanho da estrutura em relação com a globalidade de atividades.

[523 - dança, nunca concorreu]

(6)

Consideramos que os apoios devem contemplar as duas tipologias de despesa, de forma equilibrada. A avaliação das propostas deverá ter em conta a coerência das despesas de estrutura face à dimensão e complexidade das actividades constantes no plano. $O$ equilíbrio orçamental na afectação de recursos humanos e logísticos estruturais deverá permitir a boa execução dos projectos, tendo não só em conta as suas necessidades mais evidentes, como também o 
devido acompanhamento e enquadramento junto dos seus públicos e territórios. O desenvolvimento de actividades culturais por parte de entidades sem fins lucrativos seria, na larga maioria dos casos, totalmente inviabilizado caso os custos associados à manutenção da estrutura não fossem elegíveis em orçamento. Por outro lado, apoiar o funcionamento da entidade, enquanto estrutura, sem se suportarem despesas directamente decorrentes do seu plano de actividades, poderia também comprometer a execução das mesmas. Pensamos que as estruturas devem sim ser responsabilizadas de forma rigorosa pela boa gestão de recursos que lhes são atribuídos, não só no momento de apresentação da proposta, mas também durante a execução da mesma.

[376 - dança, teve apoio]

66 Atividades e estrutura de forma equilibrada - A estabilidade organizacional e financeira da estrutura é garante da continuidade profissional, da sustentabilidade e da confiança dos intervenientes com vista à realização das atividades, e à concretização de todo o potencial criativo disponível. Por outro lado, o apoio às diferentes atividades (projetos artísticos) poderá constituir também um suporte importante e um estímulo para a criação de novos objetos artísticos e atividades de intervenção.

$$
\text { [363 - dança, teve apoio] }
$$

66 Atividades e estruturas de forma equilibrada. Como trabalhamos com design [...] para nós é tão importante fazer uma Exposição, que prossupõe a promoção e comunicação do design e designer como ter apoios para a produção. Sem produção não há material para expor e promover. Tudo isto não é possível obviamente sem uma estrutura. [...]

[77 - design, concorreu mas nunca teve apoio]

66

$O$ apoio financeiro quer para as actividades quer para a estrutura deve de ser distribuído de forma equilibrada. A realização dos projectos depende de quem faz parte deles mas também de quem os coordena e produz.

[386 - fotografia, teve apoio]

66 apoio financeiro deve ser distribuído pelas actividades e estrutura de forma equilibrada. Por um lado, é imperioso que as estruturas sejam apoiadas, porque as actividades produzidas são resultado de um processo contínuo que só pode acontecer se existir uma grupo de pessoas que em permanência assegurem o desenvolvimento do trabalho artístico, técnico e logístico. Por outro lado, não faz sentido apoiar as estruturas e não apoiar as actividades que a estrutura desenvolve. Embora as actividades possam e devam ter pontualmente outros apoios para além do apoio directo da DGArtes.

[377 - teatro, teve apoio] 
6 Atividades e estrutura de forma equilibrada. No entanto achamos que deveria se encontrar um sistema flexível que se adapte às candidaturas e às organizações.

[13 - outra área, nunca concorreu]

\section{Distribuição privilegiando a estrutura}

Quanto aos que se situam do ponto de vista de uma distribuição que privilegia a estrutura, defendem que isso contribui para tornar mais robustas as condições em que são realizadas as atividades e o seu acolhimento. Estão igualmente presentes aspetos ligados ao combate à precariedade. E tem maior correspondência com os apoios não pontuais.

66 O actual modelo prevê apenas a atribuição de apoio às actividades que por sua vez financiam a estrutura, o que na realidade garante apenas a sua sobrevivência sem ser suficiente. Em termos práticos a entidade necessita de financiamento para garantir elementos fundamentais/estruturais para a boa execução das suas actividades. Os elementos que consideramos relevantes e que deveriam ser financiados directamente são aqueles que são critério para a obtenção de apoio: garantir o financiamento para os espaços e equipamentos essenciais para a entidade exercer a sua actividade, garantir os recursos humanos que são necessários e em muitos casos obrigatórios pela DGArtes: Direcção artística, Direcção administrativa, Direç̧ão financeira, Comunicação (é obrigatório um plano de comunicação geral e planos específicos a cada actividade bem como estratégias de captação de públicos) e um TOC. Devem também ser equacionadas questões associadas a obrigatoriedade legal como seguros e licenças associadas à execução da actividade. Dadas as opções que nos apresentam o apoio devia ser maioritariamente para estrutura e existindo verba suficiente contemplar também as actividades.

$$
\text { [294 - dança, teve apoio] }
$$

66 Atividades e estrutura, mas maioritariamente estrutura, as despesas da estrutura são as mais necessárias, pois sem estrutura não existem atividades, isto é, atividades promovidas pela estrutura.

[39 - dança, nunca concorreu]

66 Atividades e estrutura de forma equilibrada, de forma a que a plataforma que gere a programação das actividades seja robusta e dê a melhor resposta no acolhimento, produção e promoção do programa, por isso apoio deveria dividir-se entre apoio à estrutura e às atividades. Isto porque os recursos humanos são o principal garante da atividade artística, consequentemente, as estruturas 
e as atividades não funcionam sem que hajam pessoas a trabalhar nelas. Urge por isso criar algum tipo de apoio que garanta a existência das estruturas, fortalecendo o tecido artístico, o qual, devido aos sucessivos cortes, se encontra numa situação precária e bastante instável. Na nossa opinião o apoio devia contemplar a estrutura e as atividades, mas maioritariamente a estrutura a fim de garantir o seu funcionamento.

[369 - artes plásticas, teve apoio]

6 Actividades e estrutura mas maioritariamente estrutura. Sem uma estrutura consolidada financeiramente não é possível realizar actividades nem procurar mais financiamento. Cabe ao estado garantir que o apoio financeiro permite sustentar ou apoiar de forma consolidada a estrutura. Este apoio permitirá à própria estrutura procurar/angariar mais fontes de financiamento junto de outras entidades (privadas ou não) que tendem a apoiar, sobretudo, actividades (pela nossa experiência é mais provável adquirir patrocínios, apoios específicos ou pontuais e co-produções, sobretudo, para projectos específicos )

[311 - cruzamentos disciplinares, teve apoio]

6 Pensamos que os apoios não pontuais devem prever uma parte importante para estrutura pois depreende-se a existência de co-financiamentos dos projetos como condição obrigatória para a obtenção de financiamentos da DGArtes.

[903 - cruzamentos disciplinares, teve apoio]

66 apoio deveria dividir-se entre apoio à estrutura e às atividades. Isto porque os recursos humanos são o principal garante da atividade artística, consequentemente, as estruturas e as atividades não funcionam sem que hajam pessoas a trabalhar nelas. Urge por isso criar algum tipo de apoio que garanta a existência das estruturas, fortalecendo o tecido artístico, o qual, devido aos sucessivos cortes, se encontra numa situação precária e bastante instável. Na nossa opinião o apoio devia contemplar a estrutura e as atividades, mas maioritariamente a estrutura a fim de garantir o seu funcionamento.

[325 - cruzamentos disciplinares, teve apoio]

6 Actividade e estrutura, mas maioritariamente estrutura. O financiamento à estrutura assegura a continuidade do trabalho, diminuindo a precaridade laboral no sector, garantindo as condições logísticas e humanas essenciais ao bom desenvolvimento da actividade. Uma estrutura sólida torna-se capaz de mobilizar esforços no sentido de angariação de outros financiamento. Naturalmente o plano de actividade deve ser um elemento "avaliador" do desempenho e do 
financiamento da estrutura. Acreditamos que o financiamento a projectos deve ser remetido para os Apoios Pontuais.

[388 - cruzamentos disciplinares, teve apoio]

66 Uma atividade não pode existir sem estrutura, por outro lado uma estrutura pode existir e gastar muita energia e recursos humanos em poucas atividades. O equilibrio parece-nos essencial mas tendo a valorizar estruturas com boa capacidade de trabalho e de desenvolver muito com poucos recursos.

[479 - dança, teve apoio]

66 Atividades e estrutura mas maioritariamente estrutura, pois só assim se consegue ter evolução qualitativa de projetos e um planeamento mais a longo prazo e estruturante, em vez de atividades avulsas muitas vezes sem qualquer consequência prática após o encerramento das mesmas.

[65 - música, nunca concorreu]

66 Na especificidade de estrutura [...] faz sentido que um apoio como o da DGARTES seja essencialmente estrutural. Isto porque é essencialmente da viabilização da estabilidade da estrutura tanto em termos humanos como físicos que as condições para a investigação artística (espaço aberto, cruzamento de pessoas e de projectos, capacidade de feedback contínuo) se podem concretizar, e de onde provêem as criações artísticas, sempre enraizadas na experimentação. Achamos que a distribuição do apoio financeiro pelas componentes da entidade deve ser deixado ao critério de cada uma na medida em que se adeque à sua especificidade.

[327 - outra área, teve apoio]

66 A estrutura é a génese e o motor que permite a realização de todas as atividades, sem a estrutura as atividades ou não se concretizariam ou realizar-se-iam da forma diferente, menos "estruturada", como tal, parece-nos que a forma mais adequada de distribuir o apoio financeiro seria entre atividades e estrutura, mas maioritariamente estrutura, ou, então, apenas para estrutura.

[503 - teatro, teve apoio]

66 Estrutura maioritariamente pela função formativa que poderá desenvolver--se e pela durabilidade das estruturas produtivas enquanto factor benéfico à pesquisa e criaçāo artística.

[334 - teatro, teve apoio]

6 Actividades e estrutura, mas maioritariamente estrutura, para se poder desenvolver actividades é necessário que exista uma estrutura, se a mesma estiver 
solidifica bem alicerçada, as parcerias que consegue estabelecer canalizara para as actividades que se propõem a desenvolver.

[492 - teatro, concorreu mas nunca teve apoio]

66 As diferentes realidades exigem por ventura soluções diversas, o trabalho fora dos grandes centros urbanos (Lisboa e Porto) implica mecanismos de funcionamento que dependem muito das dinâmicas criadas por colectivos artísticos permanentes, as Companhias. É dessa forma que garantimos a manutenção dos espectáculos em cena, podemos organizar a sua circulação e assegurar a permanência de expressões artísticas tradicionais [...] que mantemos quadros de trabalho regular com os públicos escolares, que animamos o dia-a-dia da vida de um Teatro com visitas guiadas, encontros e momentos de reflexão sobre a cultura na cidade e na região, etc. Dito isto, parece-nos evidente a necessidade de uma estrutura para assumir todas as responsabilidades na gestão de um Teatro, diremos que o financiamento da estrutura é fundamental, embora possamos considerar também valores para cada actividade.

[285 - teatro, teve apoio]

66 Actividades e estrutura, mas maioritariamente estrutura. A manutenção de uma estrutura de produção é a preocupação fundamental na actividade artística e, se não é apoiada, só muito dificilmente se consegue manter. As actividades contribuem para a manutenção da estrutura, mas dificilmente se realizam sem o seu apoio. Por este motivo, considero fundamental o apoio à estrutura, desde que as actividades que se propõe produzir relevem interesse e pertinência artística.

$$
\text { [375 - teatro, teve apoio] }
$$

66 Se não se apoiarem as estruturas será impossível escapar à precariedade laboral.

$$
\text { [286 - teatro, teve apoio] }
$$

6 Não tendo as estruturas meios de financiamento local (como no caso das estruturas da cidade [...] que não têm qualquer apoio financeiro da Câmara Municipal ou outros) nem atividade comercial, é o funcionamento permanente e empenhado das equipas dessas estruturas que garante os outros meios de apoio à produção das atividades, que complementam o apoio da DGArtes, e tornam possível a criação artística. Assim,parece-nos que o financiamento deve ser "Atividades e estrutura, mas maioritariamente estrutura".

[291 - teatro, teve apoio] 


\section{Apenas para a estrutura}

Os posicionamentos que defendem que os apoios devem ser apenas para a estrutura consideram que essa é a base de sustentação das atividades, da criação de condições de estabilidade das atividades. Que se justificam nas modalidades dos apoios diretos (mediante planos de atividades, aspeto referido com regularidade), para os apoios anuais e sobretudo plurianuais. Destacam esta opção como a que mais adequadamente promove a profissionalização das equipas e a sua estabilidade. É tendencialmente mais referida por entidades do domínio da programação.

66 Na nossa opinião, para garantir um plano de actividade com qualidade, diversificado e continuado, é necessário manter em funcionamento uma estrutura ao nível de trabalhadores e recursos. Sendo possível obter apoios complementares para criação (co-produções) e circulação (vendas de espectáculos, formações, etc.), mas não para estrutura, pensamos que o apoio da DGArtes devia estar maioritariamente aqui alocado. À actividade usufruem do apoio à estrutura porque são-lhe subtraídas despesas com parte da equipa, espaços e equipamentos.

[491 - cruzamentos disciplinares, teve apoio]

66

importante pq a estrutura organizacional desenvolve os projectos como tal não tem lógica não ser considerada, ao mesmo tempo isso ajudaria a criar postos de trabalho numa área já tão fragil e pouco apoiada

[78 - cruzamentos disciplinares, nunca concorreu]

6f Respondemos: "apenas à estrutura". Mas, nesta matéria, achamos oportuno expor o que pensamos da inpretação que a DGArtes faz dos conceitos estrutura e actividades, aliás, uma chaves para compreender a maior fonte de injustiças praticadas nos anteriores concursos. O sentido dado às "actividades", por parte da DGArtes, não é inocente. Não é o conjunto de actividades normais de cada estrutura, não. Na verdade, trata-se de um conjunto de acções impostas (workshops, aulas de técnicas alternativas, residências artísticas (?), etc.,etc.), valorizadas uma a uma, como factores de majoração.

[287 - dança, teve apoio]

6 Diríamos que talvez o mais lógico seja assumir os apoios como sendo apoios à estrutura (obviamente nos casos de apoios anuais e plurianuais), mediante a apresentação de um plano de actividades com as devidas projecções orçamentais mas sem a necessidade de, como actualmente, proceder a alocações de 
percentagens de difícil antecipação ou cujo detalhe muitas vezes se dilui naquilo que é a dinâmica de uma estrutura com trabalho continuado. Um apoio à estrutura para o desenvolvimento de um plano de actividades, mediante a apresentação de um orçamento coerente para ambas as vertentes parece-nos a opção mais trabalhável e de acompanhamento mais simplificado.

[27 - música, teve apoio]

6 Achamos fundamental que os apoios à estrutura sejam uma rápida realidade especialmente acima dos acordos anuais. Aliás devo defender que o primeiro pedido de apoio seja no mínimo anual, para que se estude a sua viabilidade e a sua sustentabilidade. Isto independente das várias atividades a concurso. Diz o ditado que se tem que ensinar a pescar e não dar um peixe....E, insiste-se que nada resulta se os jurados nada souberem sobre as atividades a julgar e nada saibam sobre as possibilidades de as entidades em concurso tenham para as por em vigor.

[204 - música, concorreu mas nunca teve apoio]

66 somente para estrutura; A razão de apoio pedido à dgartes é maioritariamente ligado ao funcionamento estrutural. Uma entidade com estrutura solida e apoiada de forma consistente poderá atingir os seus resultados e ampliar as suas actividades graças ao funcionamento eficaz dos seus organismos. è no nosso entender, responsabilidade da entidade concretizar e rentabilizar o plano de actividades, conseguir inclusão e acolhimento nas actividades de outras estruturas ou instituições. Se uma Fundação ou Centro Cultural convida a entidade para representar no seio da temporada, assumirá os custos e as responsabilidades necessárias para a realização do evento; assim sendo, cremos que a estrutura seja o verdadeiro núcleo de produção, criação e raciocínio duma entidade; através da estrutura será responsabilidade da entidade procurar parceiros que possam acolher propostas por ela conceptualizadas e providenciar a sua própria rentabilidade artística.

[296 - música, teve apoio]

66 O ideal, do meu ponto de vista, é que o apoio seja concedido directamente à estrutura, uma vez que é muitas vezes difícil dividir o apoio concedido por área de actividade.

[312 - música, concorreu mas nunca teve apoio]

66

Trata-se de uma dicotomia criada por quem defende que só os "projectos" ou as "actividades" devem ser apoiadas, filosofia que ganhou terreno nas mais recentes revisões do modelo de apoio às artes. Somos contra esta ideia. Defendemos a existência de estruturas de criação com um mínimo de solidez, que Ihes permita ter alguma estabilidade a médio prazo, manter um núcleo de artistas e outros profissionais por um período alargado de tempo e acreditamos 
que isso é vantajoso tanto do ponto de vista artístico quanto da "sustentabilidade" do sistema teatral em Portugal. Por outro lado, as estruturas servem para realizar "actividades" e não é imaginável que qualquer júri decidisse apoiar uma estrutura que não apresentasse um plano de actividades para o período a concurso. Entendemos, pois, que não faz sentido utilizar esta distinção como critério a priori para decidir quais as despesas elegíveis ou mesmo o grau de elegibilidade de cada uma destas "componentes".

[498 - teatro, teve apoio]

6 Defendo um modelo baseado num forte apoio às estruturas, com um apoio marginal às criações específicas (ou "actividade"). Porque isso funcionaria como incentivo para as criações irem ao encontro do público, aumentando a importância da bilheteira e da longevidade das produções, sem necessariamente se cair numa total "mercantilização" das criações.

[198 - teatro, nunca concorreu]

66 Creio que o mais correto será existir uma linha de apoio mais constante, e prolongada no tempo, que garanta a existência da estrutura.

[248 - teatro, concorreu mas nunca teve apoio]

66 Sem estrutura não há actividades. O apoio à estrutura constitui um apoio ao combate à precariedade. $\mathrm{O}$ apoio deve ser dado à estrutura, para cumprir as actividades propostas.

[322 - teatro, nunca concorreu]

\section{Depende}

Os posicionamentos que assumidamente relativizam a distribuição dos apoios consideram que isso depende de vários fatores. Do tipo de apoio e da modalidade: pontual, para atividades; anual, plurianual, à estrutura. Depende também do tipo, das necessidades e do tempo de existência da entidade. Da "excelência cultural" da entidade (maior fatia do apoio financeiro para a estrutura quando considerada como tal). Do projeto em causa, da área artística, do contributo para a sustentabilidade das entidades tendo em conta os custos globais. Do tipo e tutela das entidades/dos equipamentos: se/quando com sustentação financeira pelos municípios, então essas entidades devem poder beneficiar apenas de apoio para atividades. Está também presente entre os posicionamentos que a distribuição depende antes de mais dos objetivos de política cultural traçados. 
É um posicionamento tendencialmente mais referido por entidades que nunca tiveram apoio da DGArtes (quer tenham concorrido quer não).

64 A distribuição do financiamento deve ser a melhor para o projecto em causa. Ou seja, por vezes faz mais sentido que o financiamento seja só para a estrutura, por vezes só para actividades, por vezes para as duas de forma equilibrada...Cada projecto tem as suas características. Um projecto de publicação de um livro que exija investigação tem um quadro financeiro completamente diferente de um ciclo de cinema... A forma de distribuição do financiamento não deveria ser o factor de avaliação mas sim a forma de utilização do financiamento em função do contributo para o país.

[467 - arquitetura, concorreu mas nunca teve apoio]

66 O essencial é a sustentabilidade do projecto e a relação do montante solicitado com os custos globais. A instituição afetará os recursos do apoio para onde considerar mais adequado à sua concretização. Cada instituição proporia a afetação que melhor se adequasse aos objectivos da sua candidatura e às circunstâncias que a condicionam. A instituição poderia, em candidatura, estabelecer e fundamentar a percentagem do apoio que afetará à estrutura e ás activida-

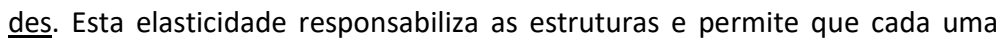
atenda às especificidades do seu território e do projecto em concreto para o qual solicita apoio. A diversidade de situações pode ficar submersa por uma lógica demasiado unívoca.

[270 - artes plásticas, teve apoio]

6 no caso dos apoios pontuais faz sentido que seja apoiada a atividade. No caso do apoio sustentado a estruturas fará sentido apoiar as estruturas

[357 - artes plásticas, concorreu mas nunca teve apoio]

6 De forma a reduzir a subsidiodependência do setor cultural, acreditamos que os apoios à estrutura organizacional devem ser revistos e repensados. De uma forma geral, vemos estes apoios como essenciais para a manutenção de "estruturas chapéu" de organização e definição de estratégias conjuntas para o setor, como associações de artistas ou espaços de programação, sejam elas temáticas ou generalistas, na medida em que estas estruturas concorrem para uma melhor regulação do setor cultural e criativo, promovendo também o reforço de dinâmicas paralelas, como o apoio organizacional, a comunicação nacional e internacional, a formação, entre outros. Desta forma, sugerimos a manutenção dos apoios à estrutura organização apenas nos casos em que se revele forte interesse comum das estruturas, em detrimento de organizações artísticas e de criação individuais. Para esses casos, o apoio deverá centrar-se nas atividades de criação/programação.

[165 - outra área, nunca concorreu] 
66 Depende de há quanto tempo a entidade recebe apoio para estrutura. As entidades que começam a receber deveriam ter mais apoio para estrutura para facilitar a sua implementação.

[385 - cruzamentos disciplinares, concorreu mas nunca teve apoio]

66 Esta questão acho que depende muito do tipo de entidade. Pois a verdade é que muitas das vezes é dificil as entidades sobreviverem apesar dos projectos que fazem e como tal apoiar a estrutura organizacional mas controladamente, poderia ser importante.

[316 - cruzamentos disciplinares, nunca concorreu]

66 Penso que nos apoios pontuais devem ser consideradas as despesas com a atividade, e nos apoios a mais anos deve existir uma preocupação no equilibrio atividade/estrutura.

[303 - cruzamentos disciplinares, concorreu mas nunca teve apoio]

66 Não existe para nós uma resposta única a essa questão. A proporção entre apoio para estrutura e atividades devia adequar-se à natureza da atividade da entidade, e os anos não se repitem obrigatoriamente. Cada atividade (criação, formação, circulação, programação) tem necessidades diferentes em termos de estrutura. A nossa experiência é que temos menos dinheiro para as criações desde que temos apoio à estrutura - mesmo as co-produções exteriores à DGArtes são "sugadas" das criações para a estrutura.

[474 - cruzamentos disciplinares, teve apoio]

66 De uma maneira geral, creio que o grande problema das artes é a falta de dinheiro para pagar aos recursos humanos. E nesse sentido, seja atividade ou estrutura deveria valorizar sempre o profissional. A DGArtes deveria ser uma entidade que se preocupava com a dignidade do artista e isso passa em primeiro lugar pela sua remuneração. A ideia de que artista ganha pouco dinheiro é a morte do artista. Do ponto de vista das instituições, assusta-me verificar como algumas dependem tanto do apoio da DGArtes. Não tendo apoio da DGArtes, não têm sustentabilidade. Isso não é saudável e a DGArtes podia procurar repensar isto. Se as instituições não sabem procurar mecenas, desenvolver trabalhos que fidelizem cada vez mais públicos e que cheguem a novos públicos, então irão fechar as portas quando não receberem financiamento. Não respondo diretamente à vossa pergunta, porque acho que é preciso ver esta questão de mais prismas.

[92 - cruzamentos disciplinares, concorreu mas nunca teve apoio] 
66 Atividades e estrutura de forma equilibrada num mundo ideal mas sempre haverá excepções. Onde uma estrutura não tem outra maneira de sobreviver Dgartes devia reconhecer esse facto talvez pedindo comprovativos e permitir um apoio mas maioritariamente a estrutura. Dgartes e/ou os novos concursos devem permitir uma certa flexibilidade onde pode-se pedir mais informação ao candidatos para justificarem as suas realidades e não generalizar ou homogenizar uma paisagem cultural no pais, cidade, bairro, etc.

[130 - dança, concorreu mas nunca teve apoio]

6 Depende do que é que estamos a falar. A escolha será a mais abrangente, neste caso. Cada estrutura (e cada projecto) é um caso singular. Há estruturas que têm o seu funcionamento garantido à partida (p.e. teatros das câmaras). Há estruturas com um trabalho muito enraizado e consistente, mas que não têm como sobreviver sem apoio regular. Quando estas estruturas fecham portas é toda uma comunidade que desaba (no caso da área da dança isto é muito visível). E aqui falamos de construção de subjectividades humanas originais baseadas num propósito de investigação e criação de mundos. Há estruturas que existem de forma negligente, por exemplo, quando têm um espaço, mas nenhum discurso (ou a repetição de discursos fáceis e reconhecíveis) e nenhuma partilha comunitária a ele associado. Há estruturas que só existem como associação porque dá jeito para poder concorrer a dinheiro para projectos e contratar pessoas para preencher formulários, orçamentos e vendas. Sou a favor da possibilidade de se usar a associação cultural sem fins lucrativos, quando há uma questão associativa a funcionar nessa associação. Também sou a favor da possibilidade do artista em nome individual, quando a questão não passa por associativismo. Sou a favor de todas as hipóteses entre um extremo e o outro, incluindo o uso de empresa e de empresário em nome individual para concorrer e declarar apoios. Contesto apenas a ideologia da indústria criativa. Acho que é um contra-senso financiar-se entretenimento.

[31 - dança, teve apoio]

66 Atividades e estrutura, mas maioritariamente atividades. As actividades têm um peso maior e mais concentrado no tempo. mas depende do tipo e duração do apoio. Se for pontual a actividade tem mais peso, se for estrutural a estrutura tem mais peso.

$$
\text { [465 - fotografia, teve apoio] }
$$

6 Os apoios pontuais deveriam servir para apoiar actividades e os anuais e plurianuais para apoiar estruturas.

[454 - teatro, concorreu mas nunca teve apoio] 
6 Na nossa opinião podem haver dois tipos de concurso, um para entidades beneficiarem de apoio para as actividade e estrutura, e consideramos que a divisão deve ser de forma equilibrada e outro tipo de apoios para entidades onde o apoio deve ser só para as actividades, pois pode haver candidaturas que a entidade não tem grande estrutura ou mesmo nenhuma, dando assim apoio total para a actividade proposta.

$$
\text { [103 - fotografia, teve apoio] }
$$

6 A distribuição do apoio deve ser feita dependendo das necessidades da entidade. De qualquer forma creio que deve ser de forma equilibrada entre a estrutura e tipologias de atividades. Tendo em conta o problema da interioridade, temos despesas de artistas e outras acrescidas, como deslocações/alimentação e.o., que podem encaixar na estrutura e mais as coisas das atividades especificas.

$$
\text { [500 - música, teve apoio] }
$$

66 Ambas devem ser consideradas. A distribuição deveria ser avaliada consoante o projecto apresentado. Dependendo da área e do projecto em causa, deve ser maioritariamente financiada a componente que mais recursos consome no desenvolvimento do projecto. À partida o programa deveria ter a flexibilidade de se adaptar à candidatura. Se o programa for demasiado rígido, dificilmente se consegue adaptar a áreas tão distintas quando as apoiadas pela DGArtes.

[203 - música, teve apoio]

66 No geral achamos que todo o processo deveria ser simplificado. O modelo proposto deveria permitir que as entidades que representam uma excelência cultural possam receber um apoio que principalmente será para a estrutura, sendo que as despesas para as atividades poderão ser mais facilmente ser suportadas pelos Municípios ou outras instituições.

[106 - música, teve apoio]

6 A questão depende muito do tipo de estrutura e da atividade desenvolvida e o tipo de apoio que deve ter. Sendo estruturas sem fins lucrativos e fins artísticos, é natural que haja necessidade de apoio equilibrado para a estrutura e atividades. Se são estruturas privadas, como produtores, não há tanta lógica para o financiamento da estrutura, apesar de poder fazer sentido apoiar um determinado projeto/atividade desenvolvida por esta estrutura, desde que aquele tenha interesse público e cultural, e não seja meramente comercial.

[277 - música, teve apoio] 
6 No caso dos TRIPARTIDOS, consideramos que como há o envolvimento de autarquias nos apoios, as despesas da estrutura podem continuar a ser suportadas pelas autarquias e a atividade pela DGArtes, desde que o orçamento total seja divido de uma forma equilibrada entre todas as partes envolvidas.

[234 - música, teve apoio]

66 Poderia existir um concurso de apoio à estrutura, em que se avalia o trabalho das entidades concorrentes no seu conjunto, mediante apresentação de plano de actividades, relatórios, bem como acompanhamento por parte da DGArtes do trabalho desenvolvido pelas entidades apoiadas. E outro concurso, destinado a projectos específicos, em que o montante alocado à estrutura diria respeito aos custos exactos com esses projectos.

[412 - música, concorreu mas nunca teve apoio]

6 Deveriam existir apoios diferenciados. Apoios estruturais subdivididos em apoios de instalação e apoios à actividade continuada de espaços artísticos. Estes apoios deveriam ser coordenados com os apoios transversais do estado à economia. Ou seja, as candidaturas a este tipo de apoios deveriam ser cabimentadas nos orçamentos e iniciativas estatais gerais de apoio à criação e manutenção de emprego mas com parecer vinculativo da DGArtes. $O$ apoio à actividade, leia-se criação e programação, deveria conter uma percentagem não superior a $10 \%$ de compra de equipamento específico para criação (luzes, equipamento cénico, material multimédia). Cenários, figurinos, adereços e outras criações associadas devem estar contabilizados como serviços.

[49 - outra área, teve apoio]

6 A questão decorre do anacronismo crónico que é a ausência de um modelo de Política Cultural. Tudo tem vindo a ser tratado de forma indiferenciada - estruturas, grupos, grupinhos, pessoas individuais...Portanto, será com base na definição de um modelo, tarefa que cumpre ao Estado, que esta matéria deverá ser encarada. Contudo, sempre dizemos que as estruturas existem para cumprir determinados programas e o seu custo deve ser imputado à realização desses programas de acordo com um projecto de gestão consistente. Do contrário existem de sobra exemplos negativos, em que o programa resulta em pouco mais que num mais ou menos apelativo portefólio, alimentando o oportunismo ou a incapacidade da estrutura (?). Portanto, em nosso entender, a estrutura deve estar ajustada ao programa e este à estrutura. Mas, insistimos em salientar, que a questão induz para uma problemática mais ampla que urge ser encarada sob pena de, se o não fizermos, dentro de 40 anos estarmos ainda a discutir este tipo de matérias.

[427 - teatro, teve apoio] 
6 Esta é uma questão que assume uma importância acrescida com o crescente sub-financiamento que se verificou nos últimos anos e que conduziu a situações muito perversas no domínio da relação laboral e da desprofissionalização crescente do sector. No domínio da criação teatral, há uma articulação necessária entre os custos ditos de actividade e os custos ditos de estrutura. Numa arte colectiva que depende de meios de produção e logísticos que assumem uma escala importante e que não decresce com a distribuição, os custos de estrutura são essenciais ao desenvolvimento da actividade. Neste campo, exige-se menos preconceito e uma melhor compreensão do que poderá ser, em cada caso concreto, o dimensionamento e a natureza dos investimentos em 'estrutura', considerando remunerações e formas de contratação justas. No caso específico das estruturas mistas (de criação e programação), sugerese a clarificação dos critérios de financiamento da actividade de programação, bem como a tomada em consideração dos custos de manutenção dos espaços. A permeabilidade desses espaços à sua utilização por terceiros deverá também ser um factor a considerar positivamente.

[505 - teatro, concorreu mas nunca teve apoio]

6

Deve ser criado um equilíbrio inteligente. A estrutura é essencial para o funcionamento pelo que não deve ser vista de forma estanque das actividades. Isso é, aliás, o que ocorre em qualquer outra empresa. Portanto nos apoios do foro plurianual há que privilegiar a racionalidade da estrutura e para isso podem ser constituídos modelos base para comparação com aqueles que surgem nas candidaturas. No que toca a apoios pontuais podem ser vistos na ótica do escalonamento de recursos, e deverão vir alocados em horas.homem face às actividades. Ou seja, do modelo que for criado para um funcionamento com $\mathrm{x}$ actividades por ano, pode ser extrapolado o valor de horas.homem usado numa actividade. De tudo isto importa reter que o apoio à estrutura é no essencial o possibilitar que os criadores possam exercer funções com dignidade e rodeados de profissionais condignamente remunerados.

[279 - teatro, teve apoio]

66

Deve ser tido em conta a natureza dos projetos e de cada uma das estruturas apresentadas a concurso. Tratando-se de projetos pontuais, deverá haver um equilíbrio das despesas elegíveis no contexto do trabalho desenvolvido pela estrutura. Nesse âmbito, parece-nos razoável que todas as despesas da atividade apoiada sejam elegíveis e que outras despesas da estrutura que, de algum modo, estão relacionadas com a execução do projeto também possam ser consideradas elegíveis. Falamos de despesas relacionadas com espaços permanentes, despesas de escritório, despesas com pessoal fixo etc. No caso dos apoios anuais e plurianuais, todas as despesas devem ser legíveis.

[7 - teatro, teve apoio] 
Matéria exclusivamente politica, no modo como a questão está colocada. As situações são diversas relativamente a cada área artística, já que o mercado também é diferente. No que ao teatro diz respeito, por exemplo: Quais as responsabilidades que o Ministério da Cultura quer assumir no desenho da futura geografia teatral em Portugal? Mais atividades e menos estruturas? Mais mobilidade de artistas e menos artistas fixos em estruturas? Mais atividades ou/ e mais tempo de exploração de cada atividade de modo a incentivar a conquista de mais espectadores? Que projeção o ministério faz para a situação do Teatro em 2030 para Portugal? Para os públicos e para os artistas? 1. Apoiar só atividades facilita o desaparecimento de estruturas, uma vez que o pensamento de todo este processo de consulta está atento, sobretudo, a estruturas que dependem de subsídios ou de compras de teatros públicos (centrais ou municipais). 2. Apoiar só estruturas, sem apoiar atividades, não nos faz muito sentido - pelo menos no modo como a questão é colocada.

[147 - teatro, teve apoio]

66

Partindo do princípio de que as estruturas existem para gerar actividade, há que considerar cada caso individualmente. É uma questão de gestão interna, dos objectivos que se pretendem alcançar, e da natureza dos projectos a desenvolver, tendo presente que se pretende apoiar as actividades artísticas e os criadores por ela responsáveis, de forma a manter a profissionalização do sector. Ora, a natureza de alguns projectos exige equipas com mais profissionais de diferentes áreas, ou mais tempo de investigação, tornando o orçamento da estrutura mais pesado. Ou, são diferentes as exigências de uma estrutura se possui, ou não, espaço próprio. Ou, por exemplo, há estruturas que proporcionam residências artísticas e que não produzem directamente um espectáculo mas proporcionam condições de criação aos artistas. Apoiar apenas actividades é condenar o sector à precariedade, ou a uma precariedade ainda maior do que aquela em que vive. As estruturas são o que permitem dar continuidade ao trabalho dos artistas, quer no que diz respeito ao desenvolvimento de uma linha de trabalho, permitindo estabelecer objectivos artísticos a médio e a longo prazo, mantendo equipas cúmplices, reunindo profissionais qualificados de diferentes áreas artísticas, quer numa perspectiva de gestão, permitindo a rentabilização dos objectos artísticos produzidos, promovendo a sua venda e circulação, a sua internacionalização e a pesquisa de outros financiamentos. No caso de estruturas com um maior historial existe todo um património de equipamentos e recursos técnicos, e um acumulado de conhecimento e boaspráticas em sectores como produção, gestão, marketing e divulgação, que assegura um desempenho mais eficaz e de qualidade.

[370 - teatro, teve apoio]

6 Depende do tamanho da estrutura e da sua actividade. Numa pequena entidade sem espaço próprio, as despesas com a actividade são muito maiores do que as com a estrutura. Já numa entidade maior, com espaço próprio, pessoal 
fixo, programação, etc., as despesas com a estrutura podem ser mais elevadas do que as com actividade.

[155 - teatro, nunca concorreu]

66 Esta perspetiva, como outras, poderia ser elaborada de forma muito dinâmica sem se encerrar num sistema fechado que possa correr o risco de não se adequar às diversas realidades. Uma estrutura pode necessitar, a dado momento, de apoio para o desenvolvimento de atividades e noutro momento necessitar de apoio para a estrutura ou ambos. As transformações nos nossos dias ocorrem por meio de dinâmicas que podem não ser previsíveis como é o exemplo das transformações tecnológicas que requerem constantes atualizações. Mas podem ser salvaguardadas pela criação mais diversificada que contemple as possibilidades inerentes ao funcionamento de uma estrutura de criação artística. Sabendo-se à partida que não têm todas sempre as mesmas necessidades mas que todas passam por essas necessidades em momento desfasados no tempo. Nesta medida podem formular-se componentes diferenciadas de apoios. Mais diferenciadas do que as presentes na questão que é aqui formulada.

[55 - teatro, concorreu mas nunca teve apoio]

\section{Mecanismos de atribuição de apoios}

A respeito dos mecanismos de atribuição de apoios por parte da DGArtes, o estudo procurou saber se, para além dos apoios que já são atribuídos através de concurso público, as entidades consideram relevante para o sector prever outros mecanismos de atribuição de apoios. ${ }^{32}$

A análise das respostas indica que a maioria dos posicionamentos é favorável a um modelo de atribuição de apoios assente em concurso público, que contemple de forma ponderada a possibilidade de outros apoios não concursais (financeiros e não financeiros) e a revisão dos apoios atualmente existentes. Em menor número, as entidades que consideram que os apoios devem ser atribuídos exclusivamente por concurso.

A maioria dos contributos incidem em propostas relativas ao tipo de "outros apoios a contemplar" ou ao tipo de aspetos específicos a alterar nos apoios atuais.

32 Q15. Para além dos apoios que já são atribuídos através de concurso público, considera relevante para o sector prever outros mecanismos de atribuição por parte da DGArtes? Por favor, fundamente a resposta. A taxa de resposta é $85 \%$. 
As entidades que se pronunciaram favoravelmente sobre um modelo sustentado em procedimentos concursais fundamentam o seu posicionamento salientando que os concursos públicos são a forma mais democrática e igualitária de acesso ao financiamento por parte do Estado. O concurso público é o mecanismo que dá, segundo as opiniões recolhidas, maiores garantias de imparcialidade do Estado.

Ao mesmo tempo que se reconhece a importância da manutenção de um modelo assente em concursos públicos, considera-se que o modelo deve ser revisto, por exemplo, quanto aos objetivos dos apoios, critérios de avaliação e competência dos júris, simplificação dos procedimentos de candidatura e flexibilização dos concursos (por exemplo, possibilidade de revisão do orçamento e atividades e/ou pedido de financiamento adicional). Estes posicionamentos incidem as suas propostas sobretudo na reorganização e reforço dos apoios existentes.

Para uma parte destas entidades, apoios sem concurso, a serem criados, devem cingir-se a apoios não financeiros, tais como reforço das iniciativas interministeriais.

As entidades que se pronunciaram favoravelmente sobre um modelo que contemple outros apoios não concursais fundamentam o seu posicionamento salientando as características do sector. Tratando-se de um sector muito diverso e dinâmico, faz sentido introduzir uma maior flexibilidade nos apoios que responda às necessidades permanentes das entidades.

Os posicionamentos que propõem uma revisão dos apoios existentes consideram essencial que o novo modelo tenha em conta as inúmeras diferenças entre as entidades do sector, quanto ao tipo, antiguidade (longo historial vs. emergentes), dimensão (por exemplo, estruturas grandes e consolidadas vs. singulares) e área artística.

No âmbito do Modelo de Apoio às Artes, uma parte significativa dos contributos procura uma resposta ao carácter dinâmico da atividade do sector. Propõe-se um quadro que assegura estabilidade e regularidade dos apoios principais, através da abertura regular e atempada de concursos, acompanhada do reforço de mecanismos de apoios pontuais/extraordinários nos períodos em que não estão previstos concursos. Reservar parte do orçamento (residual) para projetos relevantes que surjam fora do calendário ou manter uma linha de apoio pontual aberta em permanência ilustram este tipo de propostas. 
66 Seria importante prever uma linha permanente de apoio. Por vezes surgem oportunidades às entidades que mesmo conseguindo outras formas de financiamento para projectos não previstos continua a faltar algum financiamento. Fomentaria a vontade e entusiasmo de fazer outras coisas, de inovar, experimentar.

[281 - teatro, teve apoio]

G6 É fundamental prever outros mecanismos de atribuição. O sector cultural é um sector em constante desenvolvimento e intersecção com outras áreas de actividade. É aconselhável uma flexibilização que permita dar resposta a outros âmbitos de actividade e projectos paralelos, que muitas vezes decorrem das actividades desenvolvidas com carácter regular.

[244 - cruzamentos disciplinares, teve apoio]

66 Em geral o sistema está correcto. Os contratos programa para todos os tipos de concurso são a forma mais democrática e transparente de acesso a fundos públicos. Somos decididamente contra a contratação directa, por exemplo, com as "companhias históricas", isentando-as de qualquer concurso. No entanto, existem casos raros onde é necessário intervir por questões reactivas ou outras, de superior interesse nacional. Não vemos, por isso, que, excepcionalmente, estes apoios não possam existir. No caso [da entidade], a título de exemplo e, apesar de dependermos de apoios extraordinários para a realização de um dos nossos projectos bandeira [...] consideramos que esta deveria estar incluída no nosso plano de actividades, apesar de se revestir de interesse nacional, pois é parte integrante da nossa actividade regular.

[418 - cruzamentos disciplinares, teve apoio]

66

Criação de uma tipologia de concurso diferente, uma espécie de bolsa, que poderia ser temporária e estrategicamente desenvolvida, incidindo na tónica da correcção de desequilíbrios territoriais: um projecto piloto, no qual as estruturas e autarquias interessadas pudessem inscrever-se com propostas e solicitações em áreas específicas, para, com a retaguarda da tutela, encontrar parceiros estratégicos por todo o território, onde pudessem exponenciar os seus recursos e competências. Este tipo de mecanismo seria muito mais interessante do que o actual modelo de acordo tripartido, que comporta inúmeras fragilidades éticas e projectuais, bem como administrativas e legais.

[376 - dança, teve apoio]

Uma parte significativa dos contributos sublinha a importância de atribuição de apoios específicos para o perfil dos emergentes e/ou das entidades de menor dimensão, menos consolidadas. 
66 A saudável renovação do tecido, e a solidariedade entre gerações, deveria obrigar a que parte relevante dos apoios pontuais fosse integrada numa quota para artistas emergentes (fator idade).

[209 - teatro, teve apoio]

66 Penso que seria de contemplar um concurso para apoios a estruturas emergentes, nomeadamente no quadro de aquisição de meios técnicos. Deveria também ser contemplado um mecanismo de apoio para a beneficiação de infra-estruturas materiais.

[278 - cruzamentos disciplinares, teve apoio]

6 Consideramos que deveria existir uma linha de apoio a jovens criadores (até 30 anos). Este apoio deveria ser aberto apenas a pessoas singulares. Deveriam ser excluídos deste concurso criadores que já integrassem de alguma forma estruturas de produção profissionais com apoio anual/plurianual (para não existir aproveitamento dessas estruturas para duplo financiamento). Estes apoios teriam um montante a atribuir com um limite máximo de 5.000€. 0 mesmo criador não poderia beneficiar mais do que uma/duas vezes deste apoio. Esta era uma forma de criar condições para a promoção de novos criadores, bem como combater o alto grau de precariedade com muitos artistas se lançam às suas primeiras obras.

[502 - teatro, concorreu mas nunca teve apoio]

6 Apoios a estágios de novos criadores - com bolsas, por exemplo - por forma a integrar os artistas mais novos nas estruturas de criação apoiadas pelo estado;

[291 - teatro, teve apoio]

Por outro lado, emergem também posicionamentos, embora em número reduzido, que consideram relevante alterar o modelo de apoio das entidades com longo historial e atividade.

66 Consideramos fundamental haver apoios em separado para entidades com um historial suficiente, com provas dadas em resultados já atingidos, com uma estrutura apoiada pelas autarquias. Estas entidades deviam ser apoiadas através de um protocolo que envolvesse a entidade, as autarquias e a DGArtes, assegurando uma continuação do projeto e um crescimento sustentável. Estas entidades deixavam de ficar sujeitas a uma permanente dependência dos concursos, cujo resultado pode colocar em causa toda uma instituição com custos fixos e permanentes. Por outro lado, seria assim possível fazer um planeamento a longo prazo garantindo a criação de postos de trabalho permanentes. A avaliação anual a este género de protocolos devia ser feita em conjunto com 
as autarquias envolvidas e sujeita a uma atualização dos orçamentos de uma forma positiva ou negativa.

[234 - música, teve apoio]

66 Sim. Existem estruturas que pela sua história, pelas provas dadas pelos seus dirigentes, pela qualidade artística dos seus elencos e pela qualidade da obra realizada ao longo de vários anos, não deveriam depender da lógica actual que faz coabitar, no mesmo ponto de partida, propostas com diferentes capacidades, origens e ideais artísticos ainda não suficientemente implantadas ou que representam públicos minoritários. Os contratos directos nem por isso compreendem atitude elitista do Estado mas um patamar reservado a entidades que na vida profissional já provaram tudo o que é possível provar e também uma forma de estimular os mais jovens a seguir a trabalhar para um dia serem eles a estar nessa posição. A haver claro que teriam também eles que obedecer a regras de transparência como todos as instituições do Estado.

[287 - dança, teve apoio]

Do conjunto de propostas, os apoios à internacionalização recolhem boa parte dos contributos. A este respeito sugere-se adequar e/ou flexibilizar as datas dos concursos, ter mais datas ao longo do ano para permitir às entidades dar resposta às oportunidades e convites que surgem fora das datas dos concursos.

66 Quanto aos apoios à internacionalização, achamos que o concurso deveria estar aberto todo o ano, ou pelo menos de três em três meses, para dar resposta e continuidade aos esforços que as estruturas e os artistas fazem de internacionalização. Também seria importante criar uma linha de apoio à retroversão (tradução de Português para outras línguas), no sentido de promover internacionalmente o trabalho artístico nacional e, de uma forma mais prática, a legendagem de espetáculos portugueses falados em língua portuguesa. Quer o apoio à edição, quer à retroversão e à internacionalização, constituem um fator importante para invertermos a lógica de importação cultural que nos tem regido, dando a conhecer a enorme diversidade e qualidade dos projetos produzidos em Portugal.

[273 - teatro, teve apoio]

66 Apoio à circulação de criações, no âmbito internacional: dirigida a estruturas e artistas nacionais para a circulação de criações e a realização de residências artísticas portuguesas em território internacional e apoio directo aos teatros e 
festivais estrangeiros para apresentação de criações portuguesas em território estrangeiro.

Apoio à promoção de criações, no âmbito internacional: dirigida a estruturas nacionais que promovam a vinda de programadores estrangeiros para participar em acções de promoção de criações nacionais (festivais, plataformas, centro de residências/espaço de trabalho, artistas associados), dirigida a profissionais nacionais que desenvolvam trabalho na área da difusão internacional, para a realização de viagens de representação e dirigida a programadores de teatros e festivais estrangeiros que pretendam viajar para Portugal, com base no compromisso de contacto com um número mínimo de artistas (em contexto de festival, centro de residências/espaço de trabalho, artistas associados).

[396 - dança, teve apoio]

Outros mecanismos de apoios propostos de forma transversal são os apoios a espaços e equipamentos. A este respeito encontram-se propostas muito diversificadas que contemplam o mapeamento, identificação e dinamização dos espaços culturais (ou outros) sem atividade artística, para desenvolver em articulação com as autarquias a programação e a atividade nesses espaços. A partilha de recursos e espaços entre entidades é outra proposta. Neste âmbito, propõe-se também o apoio à renovação de espaços, reestruturação de salas de ensaio e o apoio a espaços de trabalho para entidades que não têm espaço próprio. E, ainda, o apoio à aquisição de equipamento técnico.

6 No que se refere a uma linha de apoio à aquisição de material técnico básico, é importante sublinhar que este apoio não é de facto apenas para uma entidade e estrutura, mas para o conjunto de projetos artísticos aí produzidos, promovidos e acolhidos.

[273 - teatro, teve apoio]

66 Os apoios a espaços de ensaios e exibição, na forma de co-pagamento de rendas, de equipamentos etc;

[291 - teatro, teve apoio]

66 Um tipo de apoio que poderia ser muito interessante é o apoio ao aluguer de espaços de trabalho, estúdio e atelier. Este tipo de apoio é uma forma simples e comprovada de promover a criação junto das novas gerações de artistas, e gerar núcleos ou centros culturais geográficos. $O$ apoio ao espaço de trabalho artístico partilhado gera o cruzamento de criadores e fomenta actividades comunitárias genuínas. A disponibilização de equipamentos imobiliários ou de verbas exclusivas para o aluguer de ateliers colectivos, estúdios e salas de tra- 
balho e ensaio, seria uma forma simples e rápida incentivar os artistas a trabaIharem localmente e manterem-se no país. Um apoio deste género, direccionado aos artistas entre os 20 e 35 anos poderia ser algo realmente marcante para a produção nacional, e poderia ser uma forma de promover as estruturas informais de artistas que se poderão transformar futuramente em projectos maiores.

[114 - artes plásticas, teve apoio]

O apoio à circulação está também muito presente nas propostas.

66 A DgArtes deveria centrar parte da sua actividade no fomento, prospecção e co- organização da circulação nacional dos projectos performativos apoiados com as autarquias, e a rede de equipamentos, tendo para isso verbas próprias. Nesta competência reside a observância dos objectivos gerais de assegurar o acesso público aos diversos domínios da atividade artística - concorrendo para a promoção da qualidade de vida, da cidadania e da qualificação das populações; de Fomentar a descentralização e dinamização da oferta cultural - corrigindo as assimetrias regionais e promovendo a atividade artística como instrumento de desenvolvimento económico e de qualificação, inclusão e coesão sociais;

[480 - música, teve apoio]

G6 Absolutamente fundamental é, também, o apoio à circulação/digressão pelo país das atividades das estruturas apoiadas pela DGArtes - tantas vezes impossível pelo magro orçamento de que dispõem as salas para acolhimentos - por forma a pôr termo à desleal concorrência com atividades de carácter comercial. O financiamento que as estruturas recebem destina-se, totalmente, à criação e divulgação dos espectáculos não sobrando verbas que possam suportar as digressões dos mesmos. $\mathrm{O}$ apoio à digressão das atividades desenvolvidas pelas estruturas apoiadas pela DGArtes tornaria possível uma maior circulação pelas salas públicas do país e um sentido acrescido ao dinheiro investidos por todos na fruição cultural por um público mais alargado.

$$
\text { [291 - teatro, teve apoio] }
$$

66 Sente-se presentemente a falta de um programa específico de apoio à circulação a nível nacional.

$$
\text { [363 - dança, teve apoio] }
$$

6 Sim, promover um concurso/medidas para circulação nacional dos criadores portugueses. A realidade dos Teatros e Auditórios Municipais é, de uma forma 
geral, de sub-financiamento e os espectáculos para circularem tem custos logísticos inerentes e, por vezes, pesados, que são muitas vezes impeditivos da contratação dos mesmos.

[366 - música, teve apoio]

6 Sim, nomeadamente para a circulação de espetáculos pelos Teatros que são financiados pelo Estado e também em áreas complementares como seja a formação de públicos.

[415 - teatro, teve apoio]

Como outro tipo de apoio a contemplar, surge a proposta de alargamento ao apoio à edição, digital e em papel.

66 Parece-nos que é importante a atribuição de apoios para a edição, no sentido de promover a escrita contemporânea para teatro e para se conseguir produzir material relevante de estudo e reflexão sobre os percursos das estruturas artísticas e artistas em Portugal, construindo assim um património físico, palpável e consultável que justifica os próprios apoios públicos.

[273 - teatro, teve apoio]

Considera-se ainda relevante contemplar o apoio técnico e jurídico às entidades, designadamente o apoio à preparação de candidaturas nacionais, europeias, internacionais. Apoio à formação de equipas técnicas em territórios/espaços que não têm equipas técnicas suficientemente competentes para dar apoio às entidades. Também se avança com a ideia de a DGArtes funcionar como incubadora de projetos e propostas para capacitar entidades/projetos não apoiados.

6 O apoio financeiro é o mais fácil. O difícil é definir como apoiar bons projetos (ou projetos com enorme potencial) que já não conseguem obter apoio financeiro. E mesmo os projetos "'classificados"'" abaixo dos limiares de qualidade, devem ser objeto de atenção, na perspetiva de que, se surgiram, é porque al- 
guém se deu ao trabalho de os pensar, estruturar e apresentar - ou seja, é porque existe ali um potencial de motivação, interesse, relevância e oportunidade. Pensamos que a DGARTES deve desenvolver os seguintes mecanismos:

1. Selo DGARTES - apoio institucional, funcionando como um selo de qualidade, a conceder a todos os projetos aos quais a DGARTES reconhece qualidade, ou seja, incluindo os apoiados e os não apoiados financeiramente;

2. Incubadora DGARTES - apoio técnico e logístico, a conceder opcionalmente (caso a entidade assim o pretenda), no qual os projetos com potencial são incubados pela DGARTES, na perspetiva do seu desenvolvimento/ apuramento, o que pode passar por: formação às entidades; apoio técnico ao desenvolvimento/ aprofundamento/melhoria do projeto; apoio técnico na exploração de financiamentos e redes/ parcerias (por exemplo, que possam incrementar componentes artísticas, reduzir custos, assegurar a colocação - acolhimento/ programação);

3. DGARTES + Perto - iniciativa de visita às entidades, podendo passar por assistir a exibições, ensaios, etc, ficando a conhecer melhor as realidades, aproximando a instituição dos artistas e formalizando e divulgando as impressões dessas visitas, que poderiam depois ser vertidas num roteiro (anual). O roteiro anual deveria balancear a cobertura geográfica (todo o território), as diferentes áreas artísticas, diferentes tipos de estruturas (mais antigas/ estabelecidas/ formais/ objeto já de apoio regular, versus as novas, emergentes, não apoiadas; grandes e pequenas - em termos infraestruturais, de estrutura/ orçamento, etc)

[442 - teatro, concorreu mas nunca teve apoio]

66 Poderiam ser considerados outros mecanismos de atribuição, tais como: -Apoio jurídico;-Aquisição de equipamentos,-Bolsas de investigação;-Apoio à escrita de textos teatrais; -Acções de formação sobre criação de dossiers para candidaturas, entre outros.Estas acções de formação poderiam ser desenvolvidas, por exemplo, através das DRCs.

[305 - cruzamentos disciplinares, teve apoio]

Por fim, outro aspeto muito referido é o do apoio à formação profissional.

6

Seria relevante criar uma linha de apoio, através da atribuição de bolsas, para criadores com um percurso considerável e profissionais de outras áreas, como produção, cenografia, luz, etc., no sentido promover a qualificação profissional e adaptação a novos conhecimentos, técnicas e tecnologias.

[273 - teatro, teve apoio]

Outra área que recolhe alguns contributos é a do apoio à investigação, em articulação com a academia e com os centros de investigação nacionais. 
64 Sim, a DGArtes deverá, além de prever outros mecanismos de atribuição de apoios, contemplar novos campos de intervenção como já referido na resposta à pergunta Q12. Os novos mecanismos de atribuição têm de contemplar a investigação artística - essencial para o desenvolvimento científico e histórico de qualquer área de estudo - atualmente com inegável ausência de apoio pela Fundação da Ciência e Tecnologia, a principal (e quase exclusiva) entidade de apoio à investigação em Portugal. Ora, se não for a DGArtes a assumir a responsabilidade de salvaguardar e promover a investigação dentro dos núcleos académicos e devidos centros de investigação de caráter artístico e/ou cultural, a evolução e a sustentação da nossa investigação ficará (está) deveras comprometida.

[478 - cruzamentos disciplinares, concorreu mas nunca teve apoio]

6

Os apoios pontuais e os apoios à internacionalização são importantes de manter. Apoiar projectos específicos na área da educação e formação seria também importante assim como projectos territoriais (artísticos e de investigação). Possibilitar a reflexão sobre os projectos e a acção artística nos territórios seria uma forma de assegurar uma melhoria continua das intervenções.

[522 - teatro, teve apoio]

1) Bolsas para artistas atenderem residências artísticas, um workshop, um encontro profissional no estrangeiro. Mas com a necessidade de agilizar o processo para a obtenção desses apoios (que também seriam bastante modestas c/ despesas elegíveis: o transporte, a inscrição - no caso de um workshop estadia).

2) Apoios (bolsas?) para projectos de investigação artística que precisam de tempo (6-12 meses) para se desenvolver e cuja finalidade é incerta a partida: exposição, livro, filme, website... Apoio ou bolsas que não têm nada a ver com as bolsas da FCT reservadas para docentes académicos.

[211 - outra área, teve apoio]

\section{Relação entre a entidade e a DGArtes}

Relativamente à relação da entidade com a DGArtes, incluíram-se no questionário três questões abertas que procuraram, de modo articulado, identificar: i) a experiência atual e anterior das entidades com a DGArtes; ii) o tipo de respostas obtidas por parte dos serviços; iii) os contributos relativamente ao papel futuro que a DGArtes deve vir a desempenhar.

De modo geral, os posicionamentos são bastante polarizados entre uma relação caracterizada positivamente e que, em alguns casos, procura evidenciar a 
falta de meios (em particular humanos) da DGArtes, e uma outra, de sentido negativo, que caracteriza a relação com a DGArtes como excessivamente burocrática, com pouco apoio técnico e jurídico, reduzida às questões concursais e oscilante ao longo do tempo em função da direção e das orientações da tutela. Uma parte significativa das entidades menciona não ter qualquer relação com a DGArtes.

De salientar que, independentemente de os posicionamentos serem mais ou menos críticos, a grande maioria das entidades reconhece um papel central à DGArtes, quer na atribuição dos apoios, quer na relação com as entidades artísticas.

\section{Relação com os serviços da DGArtes}

No que concerne a relação geral das entidades com a DGArtes, procurou-se recolher contributos sobre a experiência das entidades relativamente à DGArtes e aos seus serviços ${ }^{33}$. A questão colheu ampla participação.

O posicionamento mais frequente consiste em considerar a relação com a DGArtes como positiva ou globalmente positiva (44\%). As posições que caracterizam negativamente a experiência com a DGArtes (maioritária ou exclusivamente) representam cerca de $25 \%$ no seu conjunto. Uma parte significativa das entidades declara não ter qualquer relação com a DGArtes (27\%). Há ainda posicionamentos que relativizam a sua posição (4\%), considerando que a experiência de relação com a DGArtes varia segundo a direção em funções ou o âmbito das atividades (concursos, reuniões, programação, entre outros).

\section{Experiências positivas}

Os posicionamentos que se situam do ponto de vista de uma apreciação positiva salientam uma relação institucional de cooperação, de disponibilidade e profissionalismo por parte da DGArtes. Destacam o papel dos técnicos no apoio às candidaturas e no acompanhamento dos projetos.

33 Q16. Como descreve a relação entre a entidade e os serviços da DGArtes? A taxa de resposta é $89 \%$.

Q17.Como tem sido a resposta por parte dos serviços da DGArtes? A taxa de resposta é $82 \%$.

Q18. Como gostaria que, no futuro, os serviços da DGArtes se relacionem com a entidade? A taxa de resposta é $86 \%$. 
Importa referir que a maioria dos posicionamentos que consideram a relação positiva contribuem para identificar em todo o caso inúmeros aspetos a melhorar.

6 Tem sido uma relação cordial, de profundo respeito pela nossa missão de apoio à criação e à programação - a divulgação do património musical e o apoio à nova música e aos novos intérpretes e compositores.

[143 - música, teve apoio]

64 A nossa entidade tem tido uma relação absolutamente profissional com a DGArtes. Não temos uma relação próxima com elementos da DGArtes, mas sempre foi possível resolver todas as situações que surgiram de uma forma profissional.

[144 - artes plásticas, teve apoio]

6 A relação entre a [entidade] e a DGArtes é, em geral, cordial e positiva. Temos tido como interlocutores diretos funcionários dedicados e com vontade de resolver as questões que foram surgindo. No entanto, a grande rotatividade que tem havido nos últimos anos no seio da DG Artes tem contribuído para que o contacto não se consolide.

$$
\text { [326 - dança, teve apoio] }
$$

6 No que se refere aos procedimentos afectos às candidaturas temos encontrado bastante disponibilidade.

[327 - outra área, teve apoio]

6 Boa, embora me pareça que a DGArtes deveria ser mais interventiva quer no apoio ao desenvolvimento dos projectos, quer por exemplo na avaliação da sua execução.

[436 - música, teve apoio]

\section{Experiências negativas}

Os posicionamentos que identificam aspetos negativos (maioritária ou exclusivamente) consideram a relação com a DGArtes excessivamente burocrática, impessoal e irregular. Argumenta-se a este respeito que a plataforma de candidatura aos apoios e a complexidade das candidaturas contribuem em grande medida para acentuar este aspeto. 
Consideram, por outro lado, que a relação com a DGArtes se circunscreve na maioria dos casos aos concursos. Identificam um papel relativamente pouco interventivo, abrangente e continuado por parte da DGArtes.

No conjunto destes posicionamentos, a análise das respostas mostra que uma das principais limitações identificadas é a fraca proximidade da DGArtes com as entidades e o desconhecimento da "realidade de terreno".

Entre as entidades não apoiadas salienta-se a discricionariedade das decisões, a discutível competência dos júris, a dificuldade de acesso ao processo e a insuficiente fundamentação do resultado dos concursos. Em particular, sublinha-se a importância de uma avaliação mais fundamentada na melhoria das candidaturas futuras a apresentar.

Outro aspeto salientado é o fraco acompanhamento das entidades não apoiadas, designadamente na apresentação de candidaturas e acesso a outras fontes de financiamento (limitações referidas também pelas entidades apoiadas).

Importa salientar que uma parte dos posicionamentos que identifica aspetos negativos reconhece a limitação de recursos (em particular humanos) e em diversos casos assinala uma melhoria da relação no período mais recente.

66 A relação entre a entidade e a DGArtes é distante, marcada pela dificuldade de comunicação e pela morosidade nas respostas. É ainda uma relação altamente burocratizada e hierarquizada e as decisões (e os processos de reclamação) não são devidamente justificados.

[213 - teatro, teve apoio]

6f A nossa relação com a DGArtes é gerida quase exclusivamente através de plataformas eletrónicas (e-mails, websites etc.), sem grande proximidade. Nunca tivemos uma reunião presencial com esta entidade e raras vezes recebemos a visita dos seus funcionários nas nossas atividades ou dialogámos por telefone.

[7 - teatro, teve apoio]

66 A DGArtes é absolutamente essencial na relação de proximidade com o tecido artístico e cultural, devendo por isso, ser capacitada ao mais alto nível. As maiores falhas prendem-se com: falha sistemática nas datas de abertura dos concursos e atrasos dos mesmos, lentidão de resposta a muitas situações, nomeadamente atrasos constantes de pagamentos, plataformas informáticas frágeis e mal concebidas que não suportam o nível de utilização pretendida, falha 
frequente no envio de formulários para vários tipos de candidaturas e que atrasam os calendários, processos concursais extremamente burocráticos, acompanhamento e avaliação quase inexistente no terreno.

[418 - cruzamentos disciplinares, teve apoio]

64 Não temos tido relações com a Dgartes desde 2013. Até lá foi cordial. Mas progressivamente mais distante e tecnológica, desaparecendo cada vez mais os funcionários mesmo na assinatura de emails - muitos deixaram de ser assinados nominalmente...

[147 - teatro, teve apoio]

6 A relação tem sido no geral positiva. $\mathrm{O}$ aspecto negativo, que é bastante relevante, é que muitas vezes gera-se uma incerteza do nosso lado em relação a decisões que têm que ser tomadas devido a desvios de execução, face ao que estaria previamente planeado, naturais em processos programáticos e criativos. Ou seja, parece existir uma inflexibilidade total por exemplo ao ajustamento de verbas gastas entre atividades e rúbricas. Outra questão que gostaríamos de salientar é que os vários técnicos que acompanharam o nosso processo ao longo destes últimos anos, tinham perspectivas diferentes em relação às flexibilidades decorrentes do contrato de financiamento.

[154 - outra área, teve apoio]

66 esvaziamento de funcionários a que a DGArtes foi submetida nos últimos anos, produziu uma relação mínima reduzida muitas a emails, o que muitas vezes provocou dificuldades em ter respostas para as questões que no momento eram urgentes. Sentimos que alguma coisa vai mudando e que existe um esforço para haver um relacionamento mais direto e rápido.

[361 - cruzamentos disciplinares, teve apoio]

6 A nossa relação com os serviços da DGArtes têm-se centrado exclusivamente na gestão das adaptações que naturalmente sempre têm de ir sendo introduzidas nos programas de actividades e orçamentos. A este nível a DGArtes tem revelado sempre abertura e cooperação nos processos. Nos últimos anos, temos sentido maior empenho por parte dos técnicos em assistir a alguns dos nossos espectáculos e procurar um contacto mais pessoal

[491 - cruzamentos disciplinares, teve apoio]

66 Tendo em conta que as candidaturas apresentadas por esta entidade tem sido admitidas mas não têm sido financiadas, a relação tem sido pouco profícua, sentindo os responsáveis por esta associação que as respostas apresentadas 
têm tido fundamentação reduzida. Neste contexto a associação sente distanciamento.

[492 - teatro, concorreu mas nunca teve apoio]

66 O modelo actual assenta num pressuposto de desconfiança na forma como a DGArtes se relaciona com as entidades apoiadas. A DGArtes tem integrado, na regulamentação dos apoios às artes, a legalização da possibilidade do incumprimento dos seus compromissos. Em qualquer momento a DGArtes pode, através de decisão unilateral, reverter ou anular acordos contratualizados entre o Estado e os agentes culturais. Em caso de incumprimento, essa regulamentação só acarreta obrigações e sanções para as entidades, nunca para a DGArtes. No contacto humano, a relação é toda outra! E essa é absolutamente cordial e frutuosa. Todos os contactos pessoais que tivemos com os funcionários desta instituição foram produtivos nos resultados, compreensivos na análise das dificuldades colocadas e empáticos na relação. E este aspecto é extremamente importante.

[529 - teatro, teve apoio]

66 Consideramos a relação com a DGArtes de um modo geral positiva, pelo menos em termos formais, apesar de distanciada e demasiado longe. Uma realidade da excessiva centralidade transversal que caracteriza o País, comprovada ao longo dos anos. [...]

[494 - teatro, teve apoio]

\section{Sem relação com a DGArtes}

Uma parte significativa das entidades refere ter uma relação fraca ou inexistente com a DGArtes. Entre as entidades que referem não ter qualquer relação não são muitas as que o justificam. Em parte, são entidades de menor dimensão (medida pelo orçamento de 2016) e com uma relação de menor proximidade com o modelo (nunca concorreu ou concorreu, mas nunca teve apoio). Há ainda entidades que mencionam terem sido criadas recentemente e não terem, portanto, qualquer experiência ou experiência suficiente com a DGArtes para poder dar o seu contributo. Outras ainda são entidades que têm tido como interlocutores principalmente as direções regionais de cultura (DRC), as câmaras municipais e outros parceiros.

66 Não temos experiência suficiente para responder, em virtude de a nossa entidade ter sido fundada muito recentemente.

[41 - música, nunca concorreu] 
66 Nem bem nem mal, porem a realidade é que a não ser concorrendo nunca tivemos qualquer interacção com os serviços.

[52- música, nunca concorreu]

\section{Resposta por parte dos serviços da DGArtes}

Ainda sobre a relação com a DGArtes, procurou-se recolher contributos mais específicos sobre a experiência de resposta por parte dos serviços ${ }^{34}$. Os argumentos aqui aduzidos encontram-se muito articulados com as respostas à questão anterior. Para além das questões levantadas anteriormente, o enfoque é aqui colocado na morosidade da resposta por parte dos serviços (são inúmeras as referências às dificuldades do atendimento telefónico) e do insuficiente apoio durante o período de candidatura a concursos. Argumenta-se ainda que a resposta se limita à gestão de processos de candidaturas e contratos, ou ainda que é meramente de tipo técnico e/ou jurídico. As entidades reforçam aqui a ideia de que os recursos humanos são insuficientes para fazer face ao conjunto de solicitações, em particular durante os períodos de concurso. Consideram ainda que o calendário dos concursos tem também contribuído para uma resposta insuficiente por parte da DGArtes.

As entidades apoiadas referem ainda dificuldades de resposta aos pedidos de alteração aos projetos previstos, que obstaculizam a atividade num sector que requer flexibilidade e contínuos ajustamentos aos projetos apresentados.

66 A resposta dos serviços da DGArtes, dadas as circunstâncias da sua constituição, é positiva e com espírito de colaboração. No entanto, nem sempre as respostas surgem em tempo útil e necessário para a boa prossecução dos projetos. Este facto deve-se, do nosso ponto de vista, à progressiva diminuição de funcionários e técnicos especializados, de financiamento, bem como à frequente mudança de direções, logo de programas e linhas prioritárias de ação, que não chegam a ter tempo de ser comunicadas, aplicadas, testadas e avaliadas.

[273 - teatro, teve apoio]

6 Extremamente deficiente na resposta atempada a pedidos de alteração. Por contingências várias, ligadas às características dos locais de apresentação e à

\footnotetext{
${ }^{34} \mathrm{Q} 17$. Como tem sido a resposta por parte dos serviços da DGArtes? A taxa de resposta
} é $82 \%$. 
gestão da cultura em Portugal, houve a necessidade de enviar pedidos de autorização para alterações, na maioria dos casos pouco relevantes (alterações de datas de apresentações, ou transferência de locais). Por vezes nem foi dada resposta, ou então a resposta foi enviada depois da conclusão dos eventos programados.

[111 - música, teve apoio]

66 As relações são hoje de maior cordialidade e simpatia ainda que se sinta que não há recursos humanos suficientes para o desempenho da atividade, ao ponto de muitas vezes se ficar com a sensação de que já não está lá ninguém efetivamente a controlar o que se relata.

[209 - teatro, teve apoio]

6

1. Os resultados dos concursos da Dgartes nunca cumprem os prazos de resposta. Isso acaba por arruinar os calendários colocados nas candidaturas e gerar o caos aquando do envio dos relatórios. 2. A resposta às questões quer em relação a candidaturas quer a outras questões relacionadas com contratos ou com apresentações é sempre muito lenta. 3. A plataforma é ineficiente e nada orgânica.

[210 - música, teve apoio]

66 Os técnicos são muitos prestáveis no contacto telefónico, mas temos sentido as seguintes dificuldades: - ausência de resposta nos contactos por email; - trocas consecutivas de técnicos de acompanhamento, sem sentirmos que o "dossier" foi passado e que o processo está a ser devidamente acompanhado; - ausência de articulação entre os técnicos de acompanhamento artístico e acompanhamento financeiro.

[24 - outra área, teve apoio]

6 A DGArtes privilegia sempre estruturas e entidades com percursos já consolidados, que detêm acesso a outros apoios / mecenas, entre outros, tornandose muito difícil para as outras pessoas / entidades (sem acesso a essas redes) poderem realizar as suas actividades com apoio do Estado. O Estado (e a DGArtes, por conseguinte) deveria procurar apoiar projectos de excelência, que dificilmente conseguem aceder a outros tipos de apoio. Para tal, deveria existir uma diferenciação por patamar de acordo com a "maturidade" da entidade.

[25 - arquitetura, concorreu mas nunca teve apoio]

66 Os prazos de concursos que visam apoios, não deveriam ser, como têm sido, com prazos irreais e tardios, ou seja para o próprio ano corrente, deixando muitas vezes, meses e até anos a "descoberto" de apoios. Muito especificamente, os prazos, com os quais a DGArtes é excepcionalmente rigorosa para 
os candidatos a apoios, não é da mesma forma excepcionalmente cumprida por parte da DGArtes, nomeadamente nas respostas aos pedidos de alteração das actividades em curso, das entregas de relatórios e os vários contactos da nossa entidade, deixando por vezes a sensação de estarmos a fazer relatórios excessivamente burocráticos, que nos obriga a ceder um tempo excessivo para esse efeito exclusivo e não para as actividade artísticas que são a nossa prioridade, o que também obriga a DGartes a dedicar um excessivo tempo na sua revisão, correcção e análise, se de facto os relatórios são revistos e avaliados com a mesma minúcia com que nos pedem que sejam preenchidos.

[414 - teatro, teve apoio]

66 Lenta, atrasada e com pouco respeito pelos parceiros como são as companhias de teatro. Recorde-se como foi feito o anúncio dos apoios para 2017 por exemplo, ou como se esperam meses por alterações solicitadas relativas a agendamentos na própria plataforma.

[415 - teatro, teve apoio]

66 A Dgartes tem dado sempre resposta aos nossos pedidos, com grande cordialidade e disponibilidade. No entanto, algumas vezes torna-se evidente a escassez de meios para que um serviço tão centralizado em Lisboa possa atender às solicitações de estruturas existentes por todo o país. Defendemos uma descentralização que confira maior valorização do poder local, por exemplo com a atribuição de mais competências às Direções Regionais de Cultura.

[484 - teatro, teve apoio]

\section{Relação futura com a DGArtes}

No que concerne à relação da entidade com a DGArtes, procurou-se, por fim, recolher contributos sobre o modo como as entidades gostariam que fosse o papel desempenhado por este organismo no futuro ${ }^{35}$. Das três questões, esta foi a que recolheu propostas com maior grau de aprofundamento.

$\mathrm{Na}$ análise das respostas destaca-se desde logo um aspeto muito presente, em várias tonalidades que sustentam a necessidade de uma "humanização" da relação com as entidades. A grande maioria das entidades, como referido anteriormente, perceciona a relação com a DGArtes como demasiado impessoal, burocrática e distante.

A grande maioria dos posicionamentos sublinha a necessidade de maior proximidade entre a DGArtes e as entidades artísticas. Os argumentos aduzidos

\footnotetext{
${ }^{35}$ Q18. Como gostaria, no futuro, que os serviços da DGArtes se relacionem com a entidade? A taxa de resposta é $86 \%$.
} 
são inúmeros: maior conhecimento do contexto onde estas operam, maior conhecimento das atividades e das estruturas, maior oportunidade para criação de sinergias. Em articulação com esta ideia propõe-se maior acompanhamento e visitas regulares às estruturas e às atividades.

Os posicionamentos consideram também que o papel da DGArtes deve ser cada vez mais o de um parceiro das entidades, com maior corresponsabilização da DGArtes na realização bem-sucedida dos projetos. Inúmeras propostas vão no sentido de desenvolver a resposta dos serviços no que diz respeito ao apoio a candidaturas. Estas propostas têm sobretudo origem em entidades de menor dimensão (medida pelo orçamento de 2016) e com uma relação de menor proximidade com o modelo (nunca concorreu ou concorreu, mas nunca teve apoio).

Entre as apoiadas, outro aspeto muito salientado refere-se à importância fundamental do cumprimento dos calendários, pagamento atempado dos contratos e transparência nas decisões finais sobre as candidaturas. Consideram ainda que a DGArtes deve promover de forma ativa a informação atempada, divulgação e formação sobre concursos e oportunidades de financiamento, designadamente os de âmbito internacional, como os fundos europeus. As propostas incluem ainda a maior qualificação dos técnicos da DGArtes e o reforço dos mecanismos de atendimento (através da criação de gabinetes de apoio, helpdesk, linhas de apoio telefónico).

As propostas contemplam ainda um maior conhecimento do sector, através de estudos, do mapeamento das estruturas e atividades das entidades artísticas, a nível regional e nacional.

G6 Necessitamos de uma proximidade maior e um maior conhecimento do terreno onde nos movemos (fora dos grandes centros). Apesar da disponibilidade dos serviços, penso não haver um conhecimento in loco da realidade das estruturas do interior. Penso que seja necessária maior autonomia das Direcções Regionais, um acompanhamento mais próximo, melhor conhecimento das estruturas, do seu trabalho e dos problemas que enfrentamos

[437 - teatro, teve apoio]

6 De futuro gostaríamos que se mantivessem as boas relações que desenvolvemos e uma maior proximidade a nossa entidade.

[438 - teatro, teve apoio] 
64 Que proporcionassem um serviço de apoio ou consultadoria à elaboração de candidaturas e que procurassem conhecer, no terreno, TODAS as entidades do sector, mesmo aquelas que não são mediáticas mas que poderão desenvolver tão bom ou melhor trabalho que as outras.

[61 - teatro, teve apoio]

6 Com um maior envolvimento nos projectos, nomeadamente ao nível da ges$\underline{\text { tão, }}$ promovendo sinergias, informando acerca de iniciativas potencialmente relevantes para cada entidade e/ou projecto, como agentes conhecedores da realidade e implicados nela. Seria extremamente útil que a DGArtes pudesse intermediar o conhecimento de outras fontes de financiamento, por exemplo internacionais, e apoiasse as respectivas candidaturas. Gostaríamos que a DGArtes visse efectivamente as actividades que desenvolvemos, que falasse connosco de tempos a tempos para medir o pulso às dificuldades e sucessos que vamos vivendo. Seríamos assim mais parceiros do que entidade de tutela e entidade tutelada. A atribuição de um gestor específico a cada projecto seria também uma forma de estreitar relações com proveito para ambas as partes.

[62 - teatro, teve apoio]

66 A apresentação de um projeto, dentro da minha maneira de ver as coisas, devia ser como um contrato estabelecido entre a entidade e a DGARTES, onde todos têm a responsabilidade de fazer acontecer aquele projeto, vejo a DGARTES não só para avaliação para o financiamento do projeto, mas também, para conjuntamente melhorar o projeto, um projeto tem sempre pontos a melhorar (a partilhar pareceres, a facilitar contactos, a envolver redes de parceria entre artistas, entre outros).

[104- cruzamentos disciplinares, nunca concorreu]

6f Gostaríamos que existissem reuniões periódicas entre as entidades e a DGArtes.

[113 - música, teve apoio]

6 Nós gostaríamos que no futuro a relação com os serviços da DGArtes fosse mais continuada e menos distante. Uma delegação da DGArtes sediada fisicamente no Porto seria algo, na nossa opinião,essencial ao melhor acompanhamento das instituições da região norte. Para nós não faz sentido que os serviços da DGArtes estejam centralizados na capital, e é da nossa opinião que este é um dos factores que mais contribui para um fraco reconhecimento das entidades fora da capital, e também para um fraco acompanhamento das activida- 
des que são realizadas ao abrigo dos apoios da DGArtes na região Norte. (Falamos da região norte por ser a que nos é familiar, mas supomos que o mesmo poderia ser dito pelas entidades do centro ou do sul)

[114 - artes plásticas, teve apoio]

6 A relação com os técnicos tem sido boa, no geral, mas sentimos que não têm a disponibilidade de tempo para cumprir com todos os processo que têm a seu cargo e daí que os processos administrativos sejam mais morosos. Gostaríamos de ter uma relação mais próxima com a DGArtes, técnicos que nos responsáveis pelo processo e comissões de acompanhamento, através de visitas de monitorização e acompanhamento. Desde o 2013 que temos o apoio quadrianual, e ao nosso ver recebemos poucas visitas de monitorização e acompanhamento, que permitiriam à DGArtes avaliar mais de perto a implementação de projetos, dificuldades, adequação dos programas à realidade das organizações artísticas, qualidade de execução dos projetos, do ponto de vista da gestão de recursos e artístico. Para além disso consideramos também importante que pudesse existir um maior contacto entre projeto financiados pela DGArtes, como um encontro anual.

[154 - outra área, teve apoio]

6

Gostaria que houvesse um gabinete de apoio gratuito ao preenchimento das papeladas e de aconselhamento artístico e estrutural de como concorrer aos financiamentos diversos para concretização de projectos e rede de entidades onde apresentar os projectos/curadores/agentes. Existem para tal fundos europeus e recebi este tipo de ajuda preciosa em Berlim. Seria bom sentir esse apoio aqui em Portugal também.

[193 - música, nunca concorreu]

6 Penso ser fundamental abrir um diálogo construtivo sector por sector com as entidades certas de forma mais próxima. Na música, penso que devem auscultar a AMAEI - Associação de Músicos Artistas e Editoras Independentes e a WHY Portugal, plataforma de internacionalização da música, que tem ligações aos restantes Export Offices Europeus para a música actual. São iniciativas "grassroots" do sector da nova música portuguesa.

[194 - música, concorreu mas nunca teve apoio]

6

(...) Em conclusão, entendemos que ha uma maquina pesada mas que necessita de ser melhorada.

[208 - artes plásticas, nunca concorreu] 
66 Como parceiros para uma missão comum, como membros de uma mesma equipa na prossecução de um serviço público. De um modo próximo que permita conhecer a realidade artística e social de cada estrutura. Naturalmente sem perder o rigor no controlo entre plano/relatório e orçamento/contas, pois este é fundamental para a legitimação do apoio às artes perante os contribuintes.

[209 - teatro, teve apoio]

6 1. Gostaria que fossem mais próximos e isso também significa que o controlo é maior.

2. Mais célere resposta (ter um tempo máximo de resposta estabelecido)

3. Que cumpram os prazos de publicação de resultados de candidatura, envio de contratos, pagamentos etc.

4. Ter por exemplo um chat directo com a Dgartes ou um sistema de comunicação que possa medir o tempo de resposta dos serviços e avaliar a qualidade. Assim os assuntos seriam encaminhados de uma forma mais eficiente.

5. A dgartes deveria também prestar apoio organizacional às entidades

[210 - música, teve apoio]

6 Achamos que deveria haver encontros de trabalho com as estruturas de cada região com a regularidade quadrimestral, como forma de avaliar práticas e estreitar a reflexão sobre grandes temas de política cultural e/ou de cooperação para atingir etapas mútuas que favoreçam o diálogo e uma estratégia que apenas aproxima a DgArtes das estruturas em período/motivo de concursos. Também a visita, pelo menos uma vez por ano, da Direção da Dgartes e dos técnicos que acompanham cada estrutura, seriam elementos distintivos de um clima de partilha e de constatação mais estreita da atividade que, por certo, se revelariam importantes nas decisões que implicam uma apreciação mais condizente com a realidade.

[260 - cruzamentos disciplinares, teve apoio]

6 A DGArtes poderia promover um diálogo mais frequente com o sector (representantes do sector) para poder conhecer de mais perto as dificuldades para poder dar resposta de maneira mais assertiva aos problemas levantados. Para isso, seria necessário que o sector se organizasse e tivesse representantes que pudessem comunicar de maneira objectiva e pragmática os aspectos que afectam todas as entidades e artistas.

[280 - teatro, teve apoio]

6 Gostaríamos que o processo de acompanhamento e avaliação se fizesse diretamente no território. Que os técnicos regionais pudessem oferecer um serviço de consultadoria para os financiamentos a concorrer, de esclarecimento e que 
pudessem acompanhar a evolução das entidades e as suas atividades, mais com um carater pedagógico e de auto ajuda e menos de fiscalização e punitivo.

[369 - artes plásticas, teve apoio]

66 De forma mais célere e sobretudo, com mais antecedência. É fundamental haver uma calendarização atempada por parte das DG Artes para que as estruturas consigam organizar o seu trabalho. $\mathrm{E}$ isto tem faltado de forma crassa.

$$
\text { [326 - dança, teve apoio] }
$$

66 Gostaria que a DGArtes promovesse ações de sensibilização ou formação que preparasse melhor os agentes culturais para as interações que poderão ter com a Direção-Geral, designadamente nas candidaturas a apoios financeiros.

[340 - teatro, concorreu mas nunca teve apoio]

66 Gostaríamos que:

- dessem alguma substância ao disposto no CPA em termos de acesso aos

processos;

- passassem a informar, como a lei determina, os contra-interessados relativamente às queixas que possam dizer-lhes respeito;

- que nos seus concursos passassem a honrar ou a dar alguma substância ao princípio constitucional de protecção da liberdade de criação artística, com as suas componentes de invenção, produção e difusão, em conjunto e de forma equilibrada;

- mais competência e idoneidade nas avaliações, e fundamentações mais

completas;

- mais transparência;

- mais fair play na resposta às críticas formuladas à acção da DGArtes;

- CRIAÇÃO DA FIGURA DO PROVEDOR DO/A ARTISTA, independente da DGArtes.

[416 - cruzamentos disciplinares, teve apoio]

64 Uma relação de maior proximidade e acompanhamento, uma relação de identificação de problemas e de definição de soluções e de estratégias para uma política cultural a longo prazo. Neste contexto, consideramos que o Decreto Regulamentar 35/2012 que rege a DGArtes merece uma revisão, pois, o mesmo vincula o Apoio às Artes a uma política de redução de despesa pública, o que estrangula o financiamento, perspectivas de futuro e o próprio cumprimento de Missões e Atribuições da DGArtes.

[417 - teatro, teve apoio] 


\section{Processo administrativo e plataforma eletrónica}

O estudo contempla uma questão aberta que procura conhecer a experiência das entidades com o processo administrativo, designadamente com a plataforma eletrónica de submissão de candidaturas ${ }^{36}$.

Os posicionamentos apontam para uma defesa bastante alargada da plataforma eletrónica dos apoios, com necessidade de incluir melhorias de modo a simplificar processos e adequá-los às características das entidades. Para além dos posicionamentos mais diretamente relacionados com a plataforma, o reforço do apoio à instrução das candidaturas por parte da DGArtes é outro dos aspetos enfatizados. E, ainda, atribuir maior relevância ao projeto artístico no processo de candidatura.

\section{Divulgação: calendário, abertura de concurso e resultados}

Os posicionamentos sugerem que o processo de candidatura aos apoios seja acompanhado de uma divulgação atempada dos concursos (previsibilidade e regularidade), que o calendário definido seja adequado ao calendário das entidades e que inclua as datas de divulgação dos resultados. Salienta-se a necessidade de divulgação atempada das características e especificidades de cada concurso (objetivos, verba disponível, entre outros) e ainda facultar antecipadamente às entidades os formulários de candidatura.

66 Também aqui existe um erro grave, só quando saem os concursos se fica a saber qual o objectivo prioritário (igualdade, educação, etc.) O que nos dá muito pouco tempo caso queiramos desenvolver os nossos projectos dentro desta linha, pensar na sua criação e arranjar os parceiros certos torna-se muitas vezes impossível. Esta definição deveria ser anual e divulgada no inicio de cada ano e ai seria escolha das estruturas aceitar ou não.

[52- música, nunca concorreu]

6 Nos últimos 5 anos tentei por 3 vezes e desisti. Prefiro guardar forças para a parte importante do trabalho. Refiro uma: abrir apoios à beira de férias quando

\footnotetext{
${ }^{36} \mathrm{Q} 19$. O processo administrativo de candidatura ao apoio às artes tem sido feito através de uma plataforma eletrónica e solicitação de documentos vários. Descreva a experiência da entidade e, caso tenha sugestões para o melhorar, queira fazer o favor de as enunciar. A taxa de resposta é $85 \%$.
} 
das autarquias e centros de artes ninguém sequer responde, o que seria mais que previsível, não me parece cordial nem de bom senso.

$$
\text { [261 - teatro, nunca concorreu] }
$$

66 Outra questão - devem dizer quando saem os resultados. E tentar ao máximo cumprir os prazos.

$$
\text { [263 - teatro, concorreu mas nunca teve apoio] }
$$

66 É muitas vezes difícil cumprir com o exigido. A incerteza sobre a abertura dos concursos, a abertura de concursos em Agosto (mês de férias para a maior parte das instituições municipais, empresas e outras entidades que apoiam as estruturas) dificulta o acesso a documentação comprovativa dos apoios que as estruturas têm.

[364 - teatro, teve apoio]

\section{Apoio à instrução da candidatura}

Os contributos integram ainda propostas para aumentar o apoio da DGArtes à preparação e instrução das candidaturas. Reforça-se a necessidade de haver formação para a apresentação de candidaturas e preenchimento do formulário. Este aspeto é particularmente relevante para as entidades que não têm tido relação com o Modelo de Apoio às Artes. Entre aquelas que têm relação com os apoios, encontram-se também diversas que, na ausência de apoio, contratam este serviço a outros profissionais.

66 A plataforma apresenta algumas dificuldades que poderiam ser ultrapassadas caso houvesse um interlocutor disponível na DGartes para solucionar problemas e responder a questões, mesmo nos últimos dias de preenchimento de candidaturas, habitualmente os mais concorridos. A DGArtes habitualmente esquiva-se a esta responsabilidade deixando de responder por mail ou telefone nestes últimos dias. Ainda que o faça com aviso prévio, acho que não é justificável.

[527 - teatro, teve apoio]

66 Não temos a experiência de realizar candidaturas nem essa valência no seio da nossa entidade. Temos privilegiado a contratação de profissionais que se encarregam da tarefa. $O$ feedback que temos sobre a operacionalidade da mesma é "not user friendly" e demasiado burocrática.

[74 - outra área, concorreu mas não teve apoio] 
66 Excesso de burocracia no preenchimento da candidatura, muito complexa e muito rígida. Tivemos de contratar um especialista para nos ajudar. Sozinhos seria impossível.

[182 - música, concorreu mas nunca teve apoio]

66 A DGArtes deveria ter um serviço de apoio à elaboração de candidaturas, evitando dessa forma a aquisição de serviços por parte de estranhos ao sector para preenchimento da candidatura, a exemplo do que acontece com situações similares e outros serviços do estado.

[218 - música, teve apoio]

\section{Plataforma: instrução da candidatura}

A maioria dos posicionamentos aponta para uma defesa bastante alargada do mecanismo de candidatura através de uma plataforma eletrónica, com necessidade de introduzir melhorias a diferentes níveis. Há depois um conjunto de entidades que tem (exclusiva ou maioritariamente) uma experiência positiva com a plataforma. E ainda um conjunto de entidades que, tendo feito um investimento muito grande nos últimos anos para se adaptar à plataforma, vê com muitas reservas a introdução de novas alterações.

6 Entendemos que, depois de porfiados esforços para dominar a plataforma, finalmente (!) chegámos a uma fase em que a mesma serve os intentos. Lamentável seria se, depois de anos a aprendermos a trabalhar com a actual plataforma, alguém tivesse a peregrina ideia de criar nova plataforma, obrigando os utentes a nova aprendizagem!

[108 - música, teve apoio]

6 A plataforma no seu inicio teve imensos problemas informáticos, nas actualmente está a funcionar bem e deve ser para manter até porque nestes quatro anos as associações adaptaram-se.

[151 - música, teve apoio]

Entre os que têm experiência de candidatura, uma parte refere não ter tido problemas a lidar com a plataforma. A larga maioria, no entanto, apresenta inúmeras limitações identificadas na plataforma e contributos de aspetos a melhorar a partir da sua experiência de candidatura. Entre os não apoiados, há quem 
mencione a complexidade do processo de candidatura e da plataforma como responsáveis pela não submissão de candidatura e/ou obtenção de apoios.

Elencam-se, em seguida, os principais aspetos a melhorar no processo de candidatura da plataforma de apoios que emergiram da análise das respostas dadas.

\section{Valorização do projeto artístico}

Os posicionamentos são muito consensuais quanto à necessidade de valorização do projeto artístico no processo de candidatura. Argumenta-se que os processos de candidatura têm privilegiado em demasia a componente de gestão financeira dos projetos. Em associação com esta ideia, argumenta-se também que quanto mais complexo o processo de candidatura mais se favorecem os "profissionais de candidaturas" e menos o projeto artístico em si.

66 o processo centra-se, em demasia, sobre fatores financeiros e impactos económicos dos projetos submetidos a candidatura, em grande medida, desfasados da realidade em que se movem os agentes culturais, quase sempre confrontados com outros prazos e muitas outras dificuldades impostas, inclusivamente, por outros organismos direta ou indiretamente ligados ao Estado. Sucede muitas vezes que não é possível, por exemplo, para uma autarquia garantir de forma exata o apoio (financeiro ou outro) que vai atribuir a um projeto ou estrutura, com a antecedência desejada e exigida em sede de candidatura. Situações como esta levam, em grande parte dos casos, a uma previsão inexacta, errada ou totalmente ficcionada de receitas. Apesar de defendermos que deve ser mantido um acento claro no rigor da gestão dos projetos e estruturas financiados, o foco deveria incidir de forma mais evidente sobre aspetos artísticos, contando menos para a sua avaliação outros parâmetros relacionados com a comunicação, marketing ou a gestão financeira das candidaturas. Sucede que os formulários existentes favorecem um discurso que é influenciado por modelos empresariais, que mais facilmente são preenchidos por profissionais com formação em gestão de empresas. Perde cada vez mais peso nas candidaturas os critérios artísticos dos projetos.

[7 - teatro, teve apoio]

66 Quanto mais complexo for o procedimento, mais se beneficiam os especialistas e profissionais das candidaturas e menos se valorizam os artistas.

[506 - teatro, teve apoio]

66 O modelo falha em diversos campos. Refiro-me apenas aos Apoios Pontuais, que são os únicos que conheço. De um ponto de vista global, parece-me que 
uma das grandes falhas é o pouco peso da relevância artística do projecto. Devia-se premiar boas ideias, ainda que a sua execução possa não ser perfeita. Aquilo que se verifica hoje em dia é a formação de "clusters" de currículos, a sobrevalorização da estratégia de produção e uma excessiva "profissionalização" dos campos de actuação. As obras artísticas não são isso.

[73 - teatro, concorreu mas nunca teve apoio]

\section{Simplificação do processo de candidatura}

A grande maioria das propostas incide sobre a necessidade de simplificação e desburocratização do processo de candidatura. Salienta-se a excessiva complexidade do instrumento de instrução de candidatura face às características das entidades do sector. Entre as inúmeras propostas de simplificação merece destaque a proposta de estudar um processo de candidatura em duas etapas: uma primeira, mais centrada no projeto e com informação suficiente para a tomada de decisão, uma segunda, após seleção, que integre a informação completa.

66

O processo administrativo no geral é um processo altamente burocrático, assente num pensamento e funcionamento técnico distante da realidade de maior parte das entidades artísticas. É um processo que obriga a um esforço continuado de uma equipa em se moldar a uma forma processual de organizar a informação frequentemente distante da sua forma de pensar e concretizar o projecto artístico. A plataforma, tal como está desenhada, parece pressupor que as entidades concorrentes dispõem de uma equipa com elementos especializados e experientes não só nas áreas de produção e gestão mas também e cada vez mais nas áreas de comunicação e promoção, algo que está não só distante da capacidade financeira das entidades artísticas, como da sua vocação de criação e investigação. Os critérios exigidos, as fórmulas de inserção, o pensamento inerente a esta plataforma, bem como a quantidade e especificidade de informação, obrigam a um trabalho exponencial, invisível, irrefletido na atividade real da estrutura, esforço este que não tem como se reflectir em termos orçamentais.

[507 - cruzamentos disciplinares, teve apoio]

6 A plataforma nos parece inutilmente complexa e burocrática no seu preenchimento. A Companhia teve de recorrer a especialistas para conseguir ter apoios - antes disso existia uma total desadequação entre os procedimentos administrativos e o projecto artístico. Isto tem consequências graves na atribuição de apoios - é mais valorizado o aspecto de produção que o aspecto artístico. Corre-se o risco de estar a deixar de apoiar projetos com um potencial incrível, 
afastam-se entidades sem capacidade de resposta a estas candidaturas, obrigam-se as que ainda assim conseguem a investimentos brutais (de tempo e muitas vezes de verbas também). Sugere-se SIMPLIFICAÇÃO.

[474 - cruzamentos disciplinares, teve apoio]

6

Os processos administrativos de candidatura são demasiado complicados e burocráticos. As candidaturas deviam ser mais curtas e simples. Deviam pedir menos documentos comprovativos e menos pormenores descritivos. Deviam ser mais concisas. O que, pelo contrário, deveria ser reforçado, são os contactos reais com as estruturas. Ou seja, em vez de muito trabalho de escritório a olhar para formulários, a DGArtes devia fazer mais trabalho de campo, com os seus funcionários a visitar realmente as entidades e perceber na prática e no concreto o trabalho que está a ser realizado.

[358 - teatro, teve apoio]

66 A candidatura é complexa e de certa forma muito burocrática, poderia ser numa primeira fase mais acessível e que estabelecesse as prioridades do projeto e as suas directrizes e posteriormente mais promenorizada.

[4 - teatro, concorreu mas nunca teve apoio]

66 Cada concurso deveria ter duas fases: uma primeira fase relativa à proposta artística e conceptual e uma segunda ao projecto de gestão, sendo apreciadas na segunda fase apenas as candidaturas aprovadas na primeira.

[63 - dança, teve apoio]

66 Concordamos com a plataforma e a sua forma. Talvez seja muito exigente para algumas companhias/estruturas, mas trata-se de financiamento público. No nosso caso, nas duas candidaturas apoiadas - pontuais - existe desde logo um problema, que é a lógica de gestão dos projecto, está apresentada como se de uma grande empresa se tratasse e, quem acaba por preencher os formulários são os artistas e estes nem sempre sabem as lógicas de gestão e de marketing. Por isso, cremos que para os apoios Pontuais - na sua generalidade projectos criados por artistas, sem grandes estruturas por trás - a plataforma fosse mais vocacionada para o projecto artístico em si e menos para a sua gestão. Talvez possa haver junto da Dgartes esclarecimentos, sobre a difusão do projecto à posteriori. ou então avaliar a candidatura em várias fases.

[286 - teatro, teve apoio]

66 Pensamos que o processo deveria ser menos burocrático, sobretudo porque há um enorme investimento de tempo e horas que, no caso de não haver apoio se traduz numa perda considerável a todos os níveis. Pensamos que poderia haver uma candidatura a duas fases, num primeiro momento mais leve, com o 
objectivo de fazer uma triagem, e uma segunda fase eventualmente mais próxima dos requisitos habituais.

[34 - arquitetura, concorreu mas nunca teve apoio]

\section{Historial e documentação relativa à entidade}

Diversas entidades sugerem também que a plataforma preveja um histórico da entidade com respetiva documentação, de modo a que cada nova candidatura tenha os dados da entidade constantes da candidatura anterior.

66 É um modelo tranquilo a que falta uma única vertente: ter um historial prévio da companhia, sobretudo quando tem tantos anos de actividade, e pedir menos de um historial que não cabe em tão poucos caracteres e mais, muito mais, de um projecto, das ideas, dos processos, das intenções programáticas. É desolador que tenhamos sempre de expor como tendo 'acabado de nascer'.

[217 - teatro, teve apoio]

6 Entendemos e concordamos no essencial com o processo através da plataforma electrónica. Há no entanto aspectos que merecem e precisam ser reformulados tendo em consideração a realidade das entidades a concurso. Exemplos:1. O conceito sobre a natureza de Entidade a concurso valoriza a ideia de Projecto pontual em detrimento de Entidade Artística com caracter permanente (a tal questão entre projecto, grupo ou companhia),2. Não consideramos fazer sentido que em cada concurso, a mesma entidade tenha de reproduzir documentos já enviados anteriormente, sobre a sua história, trajecto, e informações sobre seus responsáveis directos.3. consideramos que há áreas do formulário que deverão de ser reformuladas, quanto às co-produções entre estruturas apoiadas. (o conceito que vigora é o do programador e não do criador) e isso faz diferença na contabilização do número de representações em cada estrutura, mas também na gestão administrativa e contabilística a respectiva co-produção por cada parceiro,4. A designação das Actividades carecem de uma melhor definição, para um preenchimento mais homogéneo por cada entidade.

[229 - teatro, teve apoio]

G6 Entidades que já têm concorrido e sido apoiadas porquê ter de voltar a entregar documentação como por exemplo os estatutos...? Simplifique-se e responsabilize-se.

[270 - artes plásticas, teve apoio] 
6 Uma solução possível seria, por exemplo, que cada entidade tivesse uma área privada, disponível à consulta por parte dos serviços competentes da DGARtes, onde fosse possível centrar toda a documentação pertinente através de upload de ficheiro, onde constasse o historial da entidade, plano e relatórios de actividades, etc.. Deste modo, a cada nova candidatura, os agentes artísticos estariam mais libertos para se focarem apenas no projeto de criação, programação ou edição

[518 - música, teve apoio]

\section{Documentação de entidades parceiras}

Entre os aspetos que suscitam posicionamentos críticos face ao atual processo, salienta-se a necessidade de entrega de documentação a facultar por entidades parceiras. A dificuldade de conseguir atempadamente resposta por parte dos parceiros de modo a poder integrá-la no processo representa um dos principais desafios com o qual se deparam. Argumenta-se que este é um aspeto que não é inteiramente da sua responsabilidade e, neste sentido, sugerem-se modalidades de simplificação deste processo.

66 Por outro lado, coloca-nos em situações de dependencia de entidades externas, dado que se não for entregue uma carta convite ou de apoio a tempo e hora de fecho da plataforma, somos excluidos. Como lidar com entidades que não dão a carta de apoio a tempo porque ainda não querem "fechar" o valor (principalmente o Estado)?

[116 - dança, teve apoio]

66 Um outro aspecto são as tão famigeradas "cartas de apoio aos projectos". Como não deve ser desconhecido da DGArtes, há um verdadeiro mercado paralelo e fictício destas cartas. Desde cartas-fantasma ou claramente exageradas nos seus montantes, a instituições de programação que passam mais cartas do que aquelas que verdadeiramente podem suportar. 0 peso deste parâmetro devia se muitíssimo menor, sendo apenas um garante da circulação do projecto.

$$
\text { [73 - teatro, concorreu mas nunca teve apoio] }
$$

6 A entrega de comprovativos de outros apoios no acto da candidatura é uma forma de excluir candidaturas. Muitas entidades, nos prazos e datas das candi- 
daturas, não respondem a tempo. Prazo para fazer essa entrega depois da candidatura ter sido contemplada é mais sensato e parte de uma base de responsabilização com que todos temos de trabalhar.

[270 - artes plásticas, teve apoio]

66

Eliminação de penalização de não entrega de Documentos comprovativos de parcerias, acordos de coprodução, mecenas, financiamentos e outros apoios [caso aplicável]: Não é de todo justo que uma estrutura com apoio plurianual, com provas dadas, seja penalizada num ano de concurso se não tiver nesse ano comprovativo de apoios que poderá vir a ter logo a seguir ao concurso e para os quais está sempre a trabalhar.

[480 - música, teve apoio]

\section{Grau de detalhe da informação}

Em articulação com a necessidade de simplificação surge a proposta de reduzir o grau de detalhe da informação a apresentar. As entidades chamam a atenção que o grau de detalhe requerido é desajustado à realidade do trabalho dos profissionais no sector. Para cumprir com o requerido, é muitas vezes necessário incluir informação não confirmada, pouco rigorosa, "especulativa", apenas para poder instruir a candidatura. Adverte-se para os efeitos perversos deste exercício.

6 Adaptámo-nos às exigências do formulário e da plataforma ao longo dos anos, mas é verdade que esta nos parece demasiado exaustiva e há muita informação que nos parece que não é tratada, tratando-se por isso de trabalho supérfluo. Destacamos alguns pontos: a fixação de uma "agenda" no início do ano, com o grau de pormenor que é exigido, obriga a múltiplas alterações ao longo da execução dos planos de actividade. Cremos que bastaria confrontar as expectativas iniciais com o relatório final para aferir o número de espectáculos realizados. A dificuldade em acrescentar "actividades específicas" (os serviços não têm tido capacidade de "aprovar" atempadamente as solicitações que fazemos) traduz-se num desfasamento grande entre o que realmente fazemos e o que depois surge oficialmente nos relatórios. A forma como são tratadas as co-produções gerou grandes problemas ao longo dos últimos 4 anos e é necessário clarificar. Na prática, as estruturas apoiadas que fizeram co-produções entre si (num processo louvável a todos os níveis) tiveram de disfarçar essa realidade, num absurdo jogo de "gato escondido com o rabo de fora", motivado por regras que visavam, paradoxalmente, aumentar a "transparência". É 
verdade, por fim, que os formulários foram feitos para privilegiar as informações relativas aos processos orçamentais e administrativos, em detrimento das informações e dos conteúdos artísticos, o que é um contra-senso.

[498 - teatro, teve apoio]

6

A gestão e o grau de exigência deveriam ser estabelecidos à escala do financiamento. Ou seja, dando um exemplo, projectos pontuais nos patamares orçamentais de 15.000 eur não podem acabar por destinar $25 \%$ do seu orçamento para a administração e gestão. Precisam que se simplifique a gestão, para poder criar, produzir, exibir e divulgar um projecto neste patamar de apoio.

[490 - artes plásticas, teve apoio]

6

Salientando que foram introduzidas gradualmente algumas melhorias, sugerimos:

1 - O nível de detalhe requerido na introdução de dados de planeamento/execução da actividade, implicam um dispêndio elevado de tempo, dada a metodologia funcional da plataforma (campo por campo). É fundamental melhorar o potencial de exportação/importação de ficheiros (texto e cálculo), para facilitar a introdução e verificação de dados e possibilitar uma análise e comparação de dados mais ágil, alterando variáveis e aferindo resultados de forma directa.

2 - Mesmo que se entenda ajustado o nível de detalhe exigido, o nível de justificação não é adequado para o normal exercício de gestão. À execução de qualquer plano de atividades é inerente uma natural variação na sua execução e alcance dos resultados, no que é o desvio normal entre projetado e executado. Importa assim determinar o intervalo razoável para os limites desses desvios (percentuais ou valor), dentro dos quais não se aplica a obrigatoriedade de justificação.

[409 - teatro, teve apoio]

66 Inicialmente a relação com a plataforma foi bastante árdua e desgastante. A plataforma revelou-se inadequada à realidade da maioria dos projectos e à natureza das actividades. Houve, entretanto, alguns melhoramentos que agilizaram o seu funcionamento. No entanto, a mesma mantém-se pouco legível e pouco útil às estruturas como ferramenta de análise do trabalho realizado num arco temporal mais longo. $O$ seu preenchimento requer um tempo (de trabaIho) e uma precisão (detalhe, antecipação, confirmação) muito pouco compatível com os recursos disponíveis (equipas das entidades/projectos) e com o contexto real de desenvolvimento das actividades. Deve pensar-se uma plataforma mais adequada e realmente capaz de aferir e partilhar o que é verdadeiramente importante.

[530 - teatro, teve apoio] 
66 A experiência [da entidade] no atual processo de candidatura é a seguinte: como somos uma estrutura pequena, com uma equipa reduzida, nos períodos de candidatura a apoios da DGArtes toda a equipa trabalha quase exclusivamente na candidatura, devido à sua complexidade, exigência e morosidade na inserção de dados na plataforma. É um período de trabalho intenso, no qual as restantes atividades do [entidade] ficam praticamente em "stand by".

[503 - teatro, teve apoio]

\section{Orçamento, agenda e propostas de novas funcionalidades}

No conjunto dos aspetos a merecer alterações na plataforma de apoios, destacam-se o orçamento, a agenda e a bilheteira. Considera-se que os orçamentos e as agendas previstas são discriminados de forma demasiado detalhada. Propõe-se a possibilidade de descarregar o formulário para preenchimento offline e depois submeter online, designadamente a componente orçamental e de calendarização. A título exemplificativo, adverte-se da dificuldade de fazer a candidatura depender da informação prestada pelas autarquias (não conseguir conhecer o valor dos apoios com a devida antecedência).

6 O processo é relativamente simples até chegar ao plano de atividades e orçamento onde muitos itens aos quais devemos dar resposta não se enquadrarem na especificidades das atividades; como por exemplo, números de "lotação" para espaços sem "lotação" definida; ou datas concretas de programação que não estão definidas que têm de ser comunicadas. Isto faz com que muitas das informações sejam vinculadas sem rigor e outras vezes até "aleatoriamente", já que são obrigatórias, caso contrário a candidatura não é aceite. Por outro lado, por exemplo, número de sessões de exposições, por exemplo, são consideradas como sessões de espectáculos, não se podendo contabilizar da mesma forma.

[523 - dança, nunca concorreu]

6 A agenda/bilheteira por exemplo é uma das áreas da plataforma que poderia ser simplificada e feita por indicação de acções por trimestre e não por definição especifica da data de cada sessão. A área de apresentação das actividades é também muitas vezes insuficiente para a apresentação de todos os detalhes necessários à boa compreensão das actividades propostas, sendo estranho que o campo de estratégia de comunicação tenha mais caracteres que os campos de descrição das actividades, por exemplo.

[114 - artes plásticas, teve apoio] 
6 O processo administrativo é demasiado exaustivo e complexo, nomeadamente a Agenda, sobretudo em actividades de programação / festival. Não deveria ser necessário comprovativos / declarações de todos os apoios, pelo menos no acto de candidatura, muitas vezes a distância temporal entre a candidatura e a realização da actividade não permite o envio de todo o material.

[245 - teatro, teve apoio]

66 A experiência tem sido, em geral, positiva excepto no que diz respeito à secção do Orçamento. A saber: a distribuição de despesas e receitas da estrutura por cada uma das actividades em percentagem não se adequa ao tipo de exercício de uma entidade de criação artística, já que os recursos organizacionais vão sendo geridos ao longo das produções de acordo com necessidades impossíveis de prever com exactidão matemática. Acresce que o cálculo destes valores é a parte mais morosa e inútil da inserção do orçamento na plataforma. Sugerimos a simples exclusão desse procedimento.

[291 - teatro, teve apoio]

G No nosso caso, somos uma estrutura aberta ao público de 2a a sáb., 10h$12 \mathrm{~h} /$ dia, durante todo o ano, com sessões de formação sucessivas, em vários horários e com vários professores. Não faz sentido criar uma agenda de sessões/bilheteria para uma actividade desta natureza. Podemos fazer um exercício exemplificativo: contabilizemos 300 dias/ano (retirámos o domingo) e apenas a uma área da nossa actividade- aulas. Caso não agrupemos estas aulas em blocos, como optámos por fazer, criaríamos 1500 sessões ( 300 X 5 sessões/dia).

[425 - dança, teve apoio]

G6 Apesar das melhorias de que tem sido alvo, a plataforma electrónica carece de alguns ajustes para ser mais funcional e intuitiva, com particular urgência em: AGENDA (candidatura e gestão de processo)

- a listagem dos locais de apresentação deveria estar organizada por ordem alfabética para que estes sejam mais facilmente encontrados e/ou introduzidos;

- a listagem das actividades específicas deveria estar organizada por ordem alfabética para que estas sejam mais facilmente encontradas e/ou introduzidas; - as actividades não públicas deveriam também constar na listagem da agenda; - deveria poder-se colocar o local onde decorrem as actividades não públicas para gestão interna do processo;

- ao adicionar sessões na actividade específica, a ferramenta wizard só é realmente útil se se tratarem de várias sessões a acontecerem todas em dias diferentes; o sistema assume por defeito que só pode existir apenas uma sessão diária; 
ORÇAMENTOS (candidatura e gestão de processo)

- os orçamentos detalhados de cada actividade e de estrutura deveriam verter para um "documento" único e com igual detalhe, onde fosse possível verificar a qualquer momento os dados introduzidos / por introduzir, permitindo uma visão global e não fragmentada;

PAGAMENTOS

- introdução de um campo sobre plano de pagamento das tranches de apoio; com as datas em que os mesmos devem acontecer e/ou já aconteceram (útil para acompanhamento de cada processo)

[376 - dança, teve apoio]

66 Mas não sabemos se o problema é apenas do modo como a plataforma está desenhada ou antes, do entendimento da relação que a dgartes deve ter com as estruturas - que, já de si, não é nada orgânico. Um exemplo: não é valorizado o trabalho que as estruturas realizam se for para além do planeado -no relatório apenas é referido um desvio, não necessariamente positivo, em relação ao previsto. Por outro lado, uma vez que é obrigatório pedir autorização para realizar actividades extra as planeadas, a burocratizarão e falta de liberdade de acção chegam, de forma muito perversa a influenciar estruturas a não o fazer e a ignorarem essas actividades dos relatórios, e noutros casos pode mesmo contribuir para que se refreiam de fazer mais actividades.

[311 - cruzamentos disciplinares, teve apoio]

Alguns outros aspetos salientados pelas entidades são a repetição de informação em campos distintos (informação redundante e repetitiva), a possibilidade de incluir mais informação em alguns campos, como os relativos ao projeto artístico ou mesmo a anexação de documentos que considerem relevantes para a apreciação da candidatura. Propõe-se que a candidatura integre outro tipo de conteúdos (vídeo, fotografia, áudio), melhores funcionalidades do editor de texto da plataforma e o aviso em caso de não submissão de documentos obrigatórios.

6 A obrigatoriedade de carregamento de determinados documentos deveria gerar um aviso em caso de não submissão, para que não ocorressem casos de esquecimento ou de errada categorização de apoios. Por exemplo, sendo obrigatório o carregamento de cartas de confirmação de todos os apoios, ao inserir uma linha no campo relativo aos apoios, deveria surgir logo a indicação para carregar o respectivo documento comprovativo. Talvez fosse interessante alargar a plataforma a um processo de partilha e registo sobre as actividades realizadas - Galeria, para além dos relatórios, com a possibilidade de abranger vídeos, fotografias e outros registos.

[249 - dança, teve apoio] 
6G É de referir que se tem avaliado projetos artísticos apenas pelo texto, em nenhuma faculdade, em nenhum ambiente formativo os artistas são orientados para defenderem os seus projetos - criativos - utilizando apenas texto. Um ambiente que favorecesse, ainda que normalizado, a apresentação de conteúdos que admitissem a imagem, a $\underline{\text { multimédia, }}$ o $\underline{\text { som }}$ seria mais adequado à defesa de um projeto artístico.

[520 - cruzamentos disciplinares, nunca concorreu]

\section{Adequação da estrutura de candidatura às especificidades da entidade}

Diversos posicionamentos convergem na necessidade de maior adequação entre a estrutura da candidatura e as especificidades de cada entidade. Há, porém, alguma diversidade de posicionamentos relativamente aos aspetos que devem ser adequados. Para algumas, é relevante adaptar o tipo de informação solicitada à área artística. Argumenta-se que o atual desenho da candidatura está adaptado a determinadas áreas, como a do teatro, por exemplo, mas não a outras. Numa vertente mais técnica, chama-se a atenção que os campos a preencher não têm aplicabilidade para todas as áreas. Para outras entidades, a estrutura da candidatura deveria ser adaptada à dimensão da entidade e/ou à sua experiência com o Modelo de Apoio às Artes. É o caso, por exemplo, das entidades de dimensão pequena, singulares, emergentes, que não têm experiência de relação com os apoios. Merecem ainda destaque os que consideram que o processo de candidatura deve ter em conta a modalidade de apoio.

66 processo de candidatura é extremamente complexo e requer uma grande experiência profissional quer por parte dos artistas como das estruturas e competências várias ao nível artistico, de produção e financeiro. É preocupante pensar neste processo quem inevitavelmente será excluido; jovens criadores e estruturas recentes e com poucos meios. No nosso caso, nas duas candidaturas apoiadas - pontuais - existe desde logo um problema, que é a lógica de gestão dos projecto, está apresentada como se de uma grande empresa se tratasse e, quem acaba por preencher os formulários são os artistas e estes nem sempre sabem as lógicas de gestão e de marketing. Por isso, cremos que para os apoios Pontuais - na sua generalidade projectos criados por artistas, sem grandes estruturas por trás - a plataforma fosse mais vocacionada para o projecto artístico em si e menos para a sua gestão.

[286 - teatro, teve apoio] 
66 Enquanto jovem criadora, foi um chalenge completar a candidatura. Até, já foi um sucesso a candidatura ser admitida para mim. $O$ que me pareceu o mais absurdo, é o grau de precisão que exige no desenrolamento do projecto. Pareceu-me as vezes que era contraditório ao que é realmente um processo criativo : um ponto de partida que não tem uma forma fechada quando esta a se desenvolver e que precisa dum certo espaço para poder se formar. Considerando e percebendo que é importante perceber a consistência do projecto através da leitura duma calendarização,dum orçamento das justificações de entidades parcerias, há uma impossibilidade as vezes em dar datas precisas, em definir todas as actividades que vão acontecer num momento preciso, que não é necessariamente revelador dum projecto no qual não se deve investir.

[526 - dança, concorreu mas nunca teve apoio]

6 Cada caso é um caso e no exemplo crasso, como o de um projecto musical, em que as adjudicações surgem com antecedências realmente curtas e por isso impossíveis de perspectivar à distância temporal que a plataforma exige, torna-se quase impossível construir e planificar um projecto, com a limitação dinâmica da sua construção no tempo.

[473 - música, teve apoio]

As prioridades estratégicas que a DGartes propõe e a que dá peso na avaliação são, no meu entender, um obstáculo à liberdade artística dos criadores porque, não raras vezes, fazem com que as entidades alterem os seus projetos de acordo com essas prioridades que não têm relação alguma com o projeto.

[471 - dança, teve apoio]

66 A plataforma deve ser simplificada e ajustada à realidade de execução e aos diferentes concursos, tipologias e patamares de financiamento.

[496 - cruzamentos disciplinares, teve apoio]

6 Estes protocolos e procedimentos, que sabemos fazerem parte do funcionamento das entidades públicas são, no entanto, desadequados e não dão conta das especificidades inerentes ao meio. Tratar de forma semelhante coisas que são fundamentalmente diferentes parece-nos uma forma incorreta de interagir com o meio. A título de exemplo, numa candidatura, exigir elementos de avaliação que fazem sentido para um teatro ou uma companhia de dança (venda de peças para festivais internacionais, por exemplo), mas que são impossíveis de responder de forma adequada por um centro de arte contemporânea, parece-nos problemático.

[139 - artes plásticas, teve apoio] 
6 A plataforma tem funcionado relativamente bem e tem vindo a ser melhorada gradualmente. $\mathrm{O}$ único aspecto a melhorar é tentar retirar a lógica do 'teatro e espectáculo' à plataforma e tentar criar templates mais ajustados à natureza das actividades a desenvolver. Por exemplo, no meu caso particular, é muito contra-intuitivo a ideia da agenda, sessões, bilhetes e locais que não se coadunam com as actividades que desenvolvo.

[205 - artes digitais, teve apoio]

6 A plataforma cria diversas dificuldades não apenas a nível técnico. É demasiado formatada não permitindo espelhar as especificidades das estruturas. É demasiado centrada num resultado único - apresentação de espectáculos, números de público - o que não permite valorizar actividades de carácter experimental e de investigação.

[244 - cruzamentos disciplinares, teve apoio]

66 Formulários que medem numero de espectadores, número de apresentações e itens que dificilmente traduzem o universo das artes plásticas servem para quê?

[270 - artes plásticas, teve apoio]

6 A mais concreta sugestão que temos a fazer tem a ver com, na medida do possível, uma maior diferenciação de campos a preencher no processo de candidatura - adaptada consoante se tratem de projectos de criação ou de programação, e adaptada também à diversidade das disciplinas artísticas e tendo em conta as suas particularidades.

[297 - música, teve apoio]

\section{Plataforma: avaliação}

Os contributos incluem ainda um outro aspeto relativo à componente de avaliação das candidaturas. Por um lado, e em articulação com as respostas presentes na questão da relação com a DGArtes, as entidades salientam a importância de terem uma boa fundamentação e retorno relativamente ao projeto apresentado. Por outro, considera-se relevante que tenham um acesso simplificado aos resultados da candidatura, designadamente através da disponibilização da avaliação na plataforma. É ainda sugerido que haja uma articulação com as comissões de avaliação. 
66 Reconhecendo a importância do controlo de resultados, deve definir-se qual o retorno, por parte da DGArtes, da análise aos indicadores compilados, avaliação que constitui vantagem construtiva para a gestão interna, para além da análise e visão globais sobre o resultado do apoio público destes concursos.

[409 - teatro, teve apoio]

6 Deveriam manter a transparência na avaliação final com a divulgação pública dos pareceres finais dos júris. O que se passou nos últimos pontuais, em que se teria de consultar as decisões em sede das direcções de cultura foi um retrocesso. O feedback é importantissimo, uma experiência de aprendizagem com os nossos erros e com os dos colegas (mesmo quando não concordamos com a avaliação).

[49 - outra área, teve apoio]

64 Neste quadro é incompreensível que haja que ir à DGArtes, com marcação prévia, com restrições de horários e técnicas, para consultar o processo. Só se compreende como resultando da vontade deliberada em limitar o acesso dos cidadãos aos processos que Ihes dizem respeito; a administração actua ao contrário dos princípios (leis) pelas quais se devia reger.

[408 - dança, teve apoio]

66 Não nos parece errado que possa ser pedido a uma entidade promotora de uma candidatura uma correção de um pormenor. $O$ erro é quando uma questão "pequena", fácil de corrigir, leva ao indeferimento de uma candidatura que poderia ter um impacto Artístico e/ou social relevante. Ou seja, julgo que deveria ser permitida uma proposta de melhoria/correção de uma candidatura antes desta passar a indeferida.

[57 - cruzamentos disciplinares, teve apoio]

G6 Implementação de um sistema que interligue a plataforma electrónica com as comissões de avaliação prevenindo a duplicação de tarefas.

[462 - artes plásticas, teve apoio]

\section{Alterações ao projeto}

Há ainda um conjunto de entidades (anteriormente apoiadas) que avançam com propostas relativamente aos requisitos para proceder a alterações ao projeto inicial. Consideram que a necessidade de pedido de alteração prévio e justificação não é ajustada para a realidade de trabalho no sector. Apontam-se 
ainda atrasos na resposta por parte da DGArtes decorrentes desta opção. Propõe-se, deste modo, uma maior flexibilização do procedimento e eventualmente a justificação $a$ posteriori das alterações efetuadas.

66 A gestão mais difícil tem que ver com os imponderáveis. Sempre que é necessária alguma alteração ou ajuste, o mesmo é complexo e não acontece nos tempos ideias. Sobretudo para uma estrutura que programa a 4 anos, será inevitável que surjam imprevistos e alterações. Seria importante que as companhias pudessem proceder às alterações necessárias, seguidas do envio de uma justificação, que ao ser analisada validava ou não as mesmas com uma resposta efetiva.

[266 - teatro, teve apoio]

6 No processo quadrienal 2013-2016, foi visível o esforço de simplificar o preenchimento dos diversos quesitos, por mercê das novas possibilidades informáticas. O que não obstou a que, no início, tivessem surgido algumas dificuldades que, com o tempo, foram sendo ultrapassadas. Uma sugestão de melhoramento: as pequenas alterações em relação ao contratualizado anualmente, que sempre surgem em cima do acontecimento (pontuais alterações de programa, horários, etc.) deveriam ser apenas justificados a posteriori e não antes, porque nem sempre se torna exequível solicitar autorização nas datas em que estas alterações forçadas ocorrem. Uma vez que se instaurou uma saudável relação de confiança com a DGArtes, entendemos que seria mais fácil para ambas as partes uma justificação posterior, até porque se trata geralmente de pormenores que não ferem o âmago do que tem sido contratualizado.

[143 - música, teve apoio]

66 Na gestão posterior corrente, implica um acréscimo injustificável de trabalho administrativo tanto para as estruturas como para a própria DGA que invariavelmente não consegue dar resposta atempada a questões tão simples como pedidos de alteração de datas, títulos das peças, questões que aliás não devem estar dependentes de autorização da DGA.

[244 - cruzamentos disciplinares, teve apoio]

66 Sempre que precisamos de alterar uma data ou o nome de um ator, a DGArtes exige um pedido de autorização por email, sendo que a resposta chega cerca de 2 ou 3 meses depois, quando o espetáculo já aconteceu.

[264 - teatro, teve apoio] 


\section{Correspondência da plataforma com os critérios de avaliação}

Por fim, um outro aspeto salientado pelas entidades é o da necessidade de maior articulação entre a informação solicitada pela plataforma e os critérios de avaliação das candidaturas.

66 Não há a mínima correspondência entre o que se pede nos formulários (instrução dos projectos) e a forma de avaliação (critérios, parâmetros e justificações, dos bienais e tipologias superiores). Situação particularmente paradoxal, inaceitável, potenciação todo o tipo de abusos e arbitrariedades, e cuja rectificação é urgente, dispensando aliás qualquer reforma legislativas.

[515 - cruzamentos disciplinares, teve apoio]

66 À exceção do campo que refere à orçamentação do projeto - desproporcionado a alguns campos e atividades, e o qual continuo sem compreender - o modelo presente na plataforma electrónica e que permite a candidatura aos diferentes apoios é legível e claro. A grande falha deste modelo está, a meu vêr, na ausência de requisitos, de objectivos bem definidos e das exigências necessárias para a contemplação dos apoios.

[478 - cruzamentos disciplinares, concorreu mas não teve apoio]

G6 Não há a mínima coordenação entre o que se pede nos formulários de candidatura, critérios e parâmetros de avaliação, e as justificações apresentadas nas decisões finais em relação às candidaturas. $\mathrm{O}$ grau de descoordenação e arbitrariedade é muito evidente.

[299 - arquitetura, concorreu mas nunca teve apoio]

\section{Comissões de apreciação}

O estudo incluiu uma outra pergunta, de formulação aberta, que procurou conhecer a opinião das entidades relativamente às comissões de apreciação (júris) e recolher propostas neste âmbito com um objetivo prospetivo ${ }^{37}$. A questão recolheu uma ampla participação, quer por parte de entidades com larga experiência de apoios, quer por entidades com uma fraca relação com o modelo de apoios. Os contributos incidiram principalmente em dois aspetos: i) composição

\footnotetext{
${ }^{37}$ Q20. Que condições considera necessário serem asseguradas para o funcionamento das comissões das candidaturas aos concursos de atribuição de apoios (júris)? Por favor, fundamente a resposta. A taxa de resposta a esta questão é $82 \%$.
} 
e perfil dos membros a integrar a comissão de apreciação; ii) critérios relativos à avaliação das candidaturas.

A análise das repostas mostra que os posicionamentos são tendencialmente favoráveis à existência de comissões de apreciação, mas apontando diversos problemas, desde logo a composição e as competências dos seus membros. Entre os critérios que devem presidir à composição das comissões incluem-se a diversidade de perfis, experiência e conhecimento em cada área científica contemplada nos apoios, representação regional e inclusão de técnicos da DGArtes e das DRC. Importa ainda salientar a proposta de alargamento das comissões de apreciação a todas as modalidades de concursos, designadamente aos apoios pontuais.

Para assegurar o bom funcionamento das comissões de apreciação, as entidades consideram necessário que prevaleçam princípios de transparência, imparcialidade, competência, clareza e definição prévia dos critérios de avaliação. Merece ainda destaque a exigência de uma adequada fundamentação da avaliação.

\section{Composição e perfil das comissões de apreciação}

A larga maioria dos contributos teve como preocupação apresentar os princípios que devem presidir à escolha dos membros das comissões. Desde logo, reúnem consensos os princípios do rigor, isenção, competência e mérito curricular. É ainda importante para uma parte significativa das entidades que se assegure uma escolha dos membros que garanta independência face à DGArtes e às estruturas concorrentes.

Quanto ao perfil, salienta-se a necessidade de ter uma composição diversificada. Emergem, porém, posicionamentos muito diferentes relativamente ao perfil dos membros. Para a maioria, importa garantir conhecimento e experiência para cada área científica. Para algumas entidades, é importante criar diferentes comissões de acordo com a área. Para outras, o perfil deve ser diversificado quanto à região de origem. São ainda muito os contributos quanto ao perfil laboral dos membros da comissão. A participação da DGArtes nas comissões suscita posicionamentos contrastantes, com algumas entidades a afirmar a importância de garantir a sua presença (maioritariamente com funções técnicas de apoio à comissão) e outras, em menor número, a contestar a sua participação. Considera-se, ainda, que é essencial que os seus membros tenham conhecimento efetivo das entidades e dos seus projetos assente em experiência de terreno. 
66

Que venham conhecer as estruturas e que tenham conhecimento do que estão a julgar. Não é a fazer uma análise teórica sobre as projectos ou candidaturas, que se apercebem do trabalho efectuado. Devem complementar essa análise in loco, para terem a verdadeira noção do projecto.

[93 - dança, teve apoio]

66 Existe para já um problema dentro das comissões de apreciação, pois a fotografia, arquitectura, artes plásticas, design e cruzamentos disciplinares são até ao momento apreciadas pela mesma comissão, faz isto sentido? estas áreas (que estão numa só) são das que têm menos apoio, isto faz sentido? as áreas artísticas apoiadas na DGArtes já por si têm apoios desiguais, vive o país só de teatro dentro deste sector? pois normalmente os maiores apoios são para esta área. Penso que seria importante definir melhor a divisão das áreas, ainda antes de pensarmos nas comissões. Seria importante definir melhor o valor existente para apoio para que não existam áreas artísticas que praticamente têm pouco financiamento logo à partida. Quando referiram no encontro, que existem algumas das outras áreas que pouco se candidatam, penso que esta metodologia também não ajuda a que existam outras áreas artísticas que se candidatem a estes apoios e depois é importante que dentro de cada área existam pessoas que também sejam profissionais da área, pelo que não acontece no quadro conjunto referido anteriormente (fotografia, arquitectura, artes plásticas, etc).

[103 - fotografia, teve apoio]

66 Júri composto por pessoas que desenvolvam trabalho nas áreas correspondentes mas que não tenham ligações, em termos de apoios ou co-produção etc, a nenhum dos artistas/entidades a concurso.

[126 - dança, teve apoio]

66 Como já referi anteriormente tem de ter pessoas de todas as areas no juri, e por pessoas de todas as áreas quero dizer pessoas que estejam no activo e desenvolver trabalho relevante na sua área. Não faz sentido ter pessoas de arquitectura a julgar candidaturas de música, e menos ainda pessoas que não estejam no activo.

[5 - artes plásticas, nunca concorreu]

66 É fundamental que os júris sejam compostos por profissionais com formação e conhecimentos válidos e comprovados em cada uma das áreas a concurso. Seria desejável uma maior e mais evidente articulação com a academia, propondo a inclusão de um investigador ou professor universitário especializado em cada uma das áreas.

[7 - teatro, teve apoio] 
6 O mais importante seria que os membros do júri nunca deveriam poder voltar a sê-lo senão ao fim de um período muito significativo. A sua escolha deveria também recair sobre individuos com origens profissionais, académicas e/ou artísticas diversas. Os procedimentos para evitar conflitos de interesse deveriam igualmente ser refinados.

[11 - artes plásticas, nunca concorreu]

$6 \mathbf{6}$ Este ponto tem muito que se Ihe diga! Desde a isenção - transparência - idoneidade - experiência - linhas de acção e orientadoras bem definidas - verba disponível - dava para escrever uma tese sobre o assunto. o mais importante é que as comissões sejam equilibradas, conheçam o terreno e saibam o que estão a avaliar. A inclusão de estrangeiros muitas vezes desfasados da realidade portuguesa não é bom; há que saber ter um leque de membros bem formados deforma a que a avaliação seja o mais correta possível, justa e sem erros!

[23 - música, concorreu mas nunca teve apoio]

6

Deveria ser considerada a inclusão de júris de todas as áreas disciplinares e a possibilidade de reunião pessoal com um conjunto de candidatos pré-seleccionados.

[34 - arquitetura, concorreu mas nunca teve apoio]

G6 É fundamental que os decisores sejam, de facto, conhecedores da realidade e do tecido artístico. A academia está por vezes muito desafasada da realidade. Elementos que pertençam ou tenham pertencido a companhias e actuado como agentes culturais são potenciadores do descrédito do processo. Um perfil tipo deveria ser desenhado e conhecido de antemão. A nomeação de um júri deve ser alvo de nota pública. É também fundamental que as decisões do júri no processo de decisão sejam públicas, inclusive para efeitos de contestação. Tudo isto melhora a transparência do processo e reduz as situações passíveis de recurso.

[62 - teatro, teve apoio]

6 Ter competência técnica para avaliar os projetos a concurso. Ou seja, serem da área artística do projeto. Deve no entanto ter sempre alguém de áreas mais abrangente, como por exemplo da gestão cultural.

[65 - música, nunca concorreu]

6f O júri dos projetos deve ser multidisciplinar e com forte conhecimento real do circuito profissional de determinada área. É imprescindível o conhecimento das estruturas e dos projetos que circulam no meio profissional ao nível dos espetáculos. Para poderem distinguir aquilo que se escreve da prática. Deveria 
ser composto por elementos idóneos que e não tendenciosos. Nunca programadores. Pois neste caso haveria o risco de atribuírem financiamento aos projetos associados à sua programação ou redes de programação. São muito limitados a áreas muito especificas. Não Ihes reconheço capacidade nem experiencia de analisarem a importância e relevância de uma candidatura em Design.

[70 - outra área, teve apoio]

6 As comissões de apreciação não podem estar enviesadas para determinadas áreas a concurso e sem elementos com competência em outras áreas. Este tem sido, na nossa opinião, o principal problema com um predominio muito significativo de avaliadores das áreas das artes performativas e que resulta num enviesamento dos resultados para um maior sucesso destas áreas. Em tempos enviámos à DGArtes uma reclamação, baseada em resultados estatísticos concretos, que demonstra este enviesamento com taxas de sucesso muito diferentes para, por exemplo, as artes plásticas comparadas com artes performativas. Estamos disponíveis para fornecer de novo estes dados estatísticos caso assim o entendam. Avaliadores de uma determinada área terão seguramente dificuldade em saber a relevancia artística de artistas de outra área que pouco conhecem.

[144 - artes plásticas, teve apoio]

Os júris devem ser acompanhados por um serviço jurídico competente, conhecedor das regras legais aplicáveis a Concursos Públicos. Os júris devem ser constituídos por um mínimo de 7 jurados, uma vez que os ítems de apreciação são muito diversos e uma vez que parte substantiva das matérias em análise convida a apreciações subjectivas que se devem contraditar no seio dos próprios júris. Os jurados devem ser devidamente remunerados de modo a poderem, também, ser responsabilizados pelas suas decisões. Orientações posteriores à decisão do Júri, por parte da Tutela, deverão ser divulgadas publicamente e assumidas politicamente.

[147 - teatro, teve apoio]

6

Compreendemos a necessidade de diferentes comissões de avaliação, especializadas nas áreas apresentadas a concurso. Quer do ponto de vista da análise das especificidades criativas e até linguísticas de cada projecto. Parece-nos que as comissões devem ser variadas na sua composição, quer do ponto geracional quer do ponto de vista da sua formação artística e cultural. É nessa diversidade e na discussão que ela potência, que nos parece interessante encontrar os critérios de avaliação dos projectos.

[529 - teatro, teve apoio] 
Em diversos posicionamentos defende-se a inclusão de um princípio de representação regional (desconcentração) ou municipal (descentralização) nas comissões de apreciação.

64 As comissões de apreciação das candidaturas (júris) devem ser compostas por membros com capacidade técnica e científica, conhecimento do meio profissional e das entidades a apreciar a nível regional e portanto defendemos que devem ter assento nestes júris técnicos das Direcções Regionais de Cultura e outros profissionais com formação específica das áreas a avaliar.

$$
\text { [250 - música, teve apoio] }
$$

6

Para as analises serem mais justas os júris deveriam ter gente de todas as regiões envolvidas. Se há estruturas que são reconhecidas em termos mediáticos, outras há bem mais interventivas, importantes e com mais acesso aos públicos sem esta mediatização. E estas só com representantes das localidades serão bem analisadas pois são reconhecidas nos territórios onde intervém. Podem ser elementos ligados às áreas das artes, às câmaras, às Universidades ou às Direcções Regionais. Esta forma seria muito mais justa e equilibrada. E deixaríamos de escutar em termos local a frase publica " Mas estes, não fazem nada aqui e são apoiados"!, Frase comum principalmente no interior. Não sei se sabem, mas ficam desde já alertados, neste momento há estruturas no interior criadas por artistas de outras zonas que se candidatam a uma zona, só porque esta tem menos candidatos e do orçamento apoiado tiram uma parte ínfima fazem uma ou duas apresentações e vão para as suas zonas de trabalho onde tem outras estruturas já implementadas. Este é um cenário que tem vindo a aumentar de ano para ano desvirtuando o processo e deixando o interior com o mesmo nível de pobreza cultural apesar do investimento de dinheiro publico.

$$
\text { [52 - música, nunca concorreu] }
$$

46

Descentralização. Júris e processos de decisão mais próximos das áreas territoriais dos apoios, facilitando um conhecimento efetivo do trabalho desenvolvido pelas entidades candidatas.

$$
\text { [101 - dança, teve apoio] }
$$

6 A constituição das Comissões de Apreciação deveriam ser descentralizadas. Ou seja, a sua constituição deveria prever elementos que se relacionam mais diretamente com as entidades e que acompanham as atividades que são desenvolvidas. Desta forma, acreditamos que os apoios distribuídos possam ter uma relação mais direta com o território ou área geográfica de abrangência dos projetos. Por exemplo, o envolvimento das Direções Regionais de Cultura são, certamente, um elemento fundamental porque estão mais próximas dos projetos 
e das intenções das entidades. Ainda assim, considera-se que deveriam ser envolvidas as Comunidades Intermunicipais ou até mesmo os Municípios.

[269 - artes plásticas, teve apoio]

Em menor número encontram-se os posicionamentos favoráveis à inclusão de membros internacionais nas comissões de apreciação.

6 Os Juris devem ser pessoas com mérito e reconhecimento do meio artístico, não só nacional mas também internacional. Aliás, penso que seria importante convidar pessoas de nacionalidade estrangeira. As ultimas nomeações são caricatas e desprestigiantes para a DGA[rtes] mas também para estes concursos. Como pode, por exemplo, um musico avaliar a qualidade de um projecto de artes plásticas? Não pode, e não deve.

[131 - artes plásticas, nunca concorreu]

66 Júris de inquestionável mérito e idoneidade, de preferência internacionais ou integrando elementos internacionais, como acontece na ciência, p.ex., e como muitos outros arts councils fazem.

[515 - cruzamentos disciplinares, teve apoio]

\section{Seleção dos membros}

Relativamente ao modo de seleção dos membros das comissões não há muitos contributos. Entre os que referem este aspeto, propõe-se a criação de uma bolsa de peritos. Assim como assegurar a rotatividade dos membros do júri.

6 Devem existir júris representativos e comprovadamente conhecedores das várias áreas artísticas para todos os concursos, quer sejam pares ou outros especialistas. Para melhorar a capacidade do organismo da tutela de recrutar elementos para estes júris pode-se constituir uma bolsa de peritos nas diferentes áreas (artística e de gestão), mapeando recursos, dando formação e promovendo o visionamento de espectáculos (formação contínua), o conhecimento do meio e da área artística avaliada por cada um.

[116 - dança, teve apoio]

6 Deveria ser aberta uma convocatória para as pessoas se candidatarem a júris (da parte artística e de gestão/produção), que posteriormente seriam colocados numa "bolsa de peritos" e seriam alocados a cada concurso consoante a especificidade de cada concurso.

[502 - teatro, concorreu mas não teve apoio] 
66 o painel de avaliadores deveria ser composto por pessoas informadas, com currículos de excelência em cada uma das áreas. A DGArtes deveria, inclusivamente, criar uma bolsa de avaliadores por concurso público para esse fim.

[25 - arquitetura, concorreu mas não teve apoio]

\section{Divulgação prévia da comissão de apreciação}

Considera-se ainda fundamental a divulgação dos membros que compõem a comissão na fase prévia à candidatura.

66 Saber de antemão quem são os membros da comissão e as suas habilitações, em todos os apoios (pontuais, anuais, bianuais, quadrienais, tripartidos) uma vez que isso também é valorado nas candidaturas de todas as entidades. Diversidade de áreas artísticas. $O$ júri deve ser externo a todos os projectos.

[206 - dança, teve apoio]

66 Numa perspectiva de transparência, seria útil, na altura da publicação do aviso de abertura dos concursos, os candidatos poderem também ter a informação da constituição dos júris bem como da competência de cada um dos seus membros (bios).

[211 - outra área, teve apoio]

\section{Avaliação}

Relativamente à avaliação, prevalece uma preocupação com a definição prévia de critérios e pontuações, bem como a sua divulgação junto dos candidatos. Atribuir maior atenção ao historial da entidade e conhecer o trabalho das entidades "no terreno" são dois outros aspetos que emergem dos posicionamentos. É ainda salientada a necessidade de identificar escrupulosamente os casos de conflitos de interesses. No que concerne ao processo de avaliação, os posicionamentos vão no sentido de sublinhar a importância essencial da fundamentação da avaliação por parte das comissões.

6 É também muito importante que não haja conflitos de interesses nos júris que compõem as comissões de avaliação, e que quem concorra sinta que à um verdadeiro cuidado e escrutínio por parte da DGArtes para evitar que essa situações possam ocorrer.

[114 - artes plásticas, teve apoio] 
66

Independência total em relação aos 'mercados' de criação e programação, formação numa ou mais das áreas englobadas, um guião de avaliação claro.

$$
\text { [14 - fotografia, concorreu mas nunca teve apoio] }
$$

66 O trabalho do juri deverá incluir o visionamento do trabalho (de forma anónima), a análise e consistência do projecto no sector onde está incluído e por fim a sua apreciação.

[116 - dança, teve apoio]

6 Os júris deveriam ser compostos por pessoas que para além das suas competências nas áreas que avaliam, tenham um conhecimento do trabalho artístico dos candidatos. Eventualmente, deviam começar a formar-se com antecedência em relação aos concursos para permitir um acompanhamento da criação artística nacional, ou integrarem elementos das comissões de acompanhamento.

[247 - teatro, teve apoio]

6 Os júris devem ser o mais possível pessoas isentas mas conhecedoras do panorama cultural do país. Seria importante receberem por parte da DGartes uma espécie de matriz sobre o historial das entidades e respectivo historial de apoios, o seu contínuo ou não cumprimento das suas responsabilidades, enfim, qual tem sido o caminho da entidade em função dos programas de apoio da Dgartes e do seu projeto artístico(cresceu, evolui, transformou -se, alterou se...)

[281 - teatro, teve apoio]

66 Os aspetos mais relevantes são: criar júris diferentes em base regional (isto é para evitar que cada elemento do júri tenha demasiados dossier para analisar, elemento que pode tornar menos equilibrada a sua decisão), prever um encontro/audiência individual de conhecimento entre os júris e as entidades candidatas de forma que seja possível para os júris entender a complexidade de cada projeto artístico apresentado ao apoio da Dg Artes, reduzir as categorias de pontos à atribuir ao projeto de cada entidade (o elemento do júri pode ter dificuldade em atribuir tantos pontos e pensar em tantas confrontações) para 4-5 categorias, tornar obrigatória a presença de um delegado da Delegação regional correspondente no júri. Ainda melhor: deveria ser a mesma Delegação regional correspondente a fazer a nomeação dos júris na região correspondente. Hoje não existe um candidato a júri que tenha conhecimento da realidade artística de todo o país.

[106 - música, teve apoio] 
$6 \mathbf{S}$ Serem isentos. Terem experiência de campo, não serem apenas teóricos. Estabelecerem uma grelha de avaliação que faça sentido e cumprirem-na com rigor, uma vez definida.

$$
\text { [16 - teatro, nunca concorreu] }
$$

66 Tudo dependente, numa primeira instância, das regras dos concursos e sobretudo dos parâmetros de avaliação. Qualquer júri, por mais idóneo que seja fica sempre condicionado a pensar pela lógica organizacional que esses parâmetros definem. Por exemplo: se existe um parâmetro que valoriza o ensino por ex: o caso dos workshops - e se a minha real actividade é a de fazer espectáculos programados para Teatros fico em desvantagem relativamente a outros. Isto é uma realidade para a grande maioria dos parâmetros actuais. Como resolver isto? provavelmente separando as áreas artísticas em si mesmas e, dentro delas, as estruturas com objectivos específicos. Companhias que programam espectáculos, plataformas que organizam diversas actividades, estruturas mai dedicadas ao ensino à produção etc. Sem uma clarificação desta natureza à priori, qualquer júri fica sujeito à subjectividade inscrita na génese dos concursos e, até mesmo, julgar, inconscientemente a partir dos seus gostos ou de regras que não se podem ajustar de igual modo a todos.

[287 - dança, teve apoio]

66

O acesso aos relatórios de actividades e resultados obtidos bem como aos pareceres das comissões de acompanhamento, cujo trabalho deve ser sistematizado e valorizado no quadro do funcionamento geral dos apoios.

[244 - cruzamentos disciplinares, teve apoio]

66

Acreditamos que a criação de um júri independente é a melhor forma de avaliação. Contudo, é necessário mais objectividade na apreciação, objectividade essa que pode ser melhorada, por exemplo, na descrição de alguns pontos que valorizam as candidaturas. O que significa digressão nacional? Apresentar 3 espectáculos? O que significa serviço educativo? Apresentar 3 ou 4 workshops ao longo do ano? Muitas vezes, a quantidade não é especificada. Recordamo-nos do penúltimo concurso plurianual, em que o júri, em acta, deliberou que as digressões nacionais seriam tido em conta a partir de um determinado número de espectáculos. Ou seja, os candidatos souberam, posteriormente à submissão da candidatura, o número exacto de espectáculos a apresentar fora da região de Lisboa e VDT, um critério, portanto, injusto (porque definido a posteriori).

[240 - teatro, teve apoio]

6

Todas as tipologias de concurso deveriam ter júris e não só algumas. Do ponto de vista da sua composição, os júris deveriam dar equivalente garantia quanto à sua competência, idoneidade e isenção. Os critérios de avaliação deveriam 
ser revistos e adequados de modo a permitir uma melhor avaliação de cada tipo de concurso. Parte dos elementos dos júris poderiam integrar posteriormente comissões de acompanhamento e avaliação.

[376 - dança, teve apoio]

64

Devem ter em conta que as pequenas estruturas, que solicitam pequenos apoios, devem poder ter acesso a apoios tal como as grandes estruturas. Sentimos que há uma barreira a projectos de pequena dimensão, que por sua vez são os que mais necessitam. Por outro lado, devem ser valorizados os projectos artísticos de cariz mais comercial. Na música sentimos muito que continuam a ser privilegiados projectos eruditos/clássicos ou de grande dimensão. A música pop, comercial, rock, electrónica, experimental e outros géneros devem ser considerados como expressões artísticas tão válidas como qualquer outra.

[203 - música, teve apoio]

66 Os júris terão sempre preferências e inclinações pessoais. Não há maneira de as evitar. Mas o Instituto deverá assegurar que essas inclinações não são repetidamente as mesmas, bem como a observação e contradição das opiniões expressas. A minha experiência em concursos da DGArtes é que a fundamentação é de tal forma frágil e desleixada que pode ser facilmente contradita legalmente pois a observação dos critérios de avaliação é feita de modo muito pouco consistente e vago. A DGArtes deverá assegurar um mecanismo de rotatividade das personalidades e uma pré-avaliação cega, feita por critérios técnicos. O mecanismo da avaliação "cega", muito usado em publicações científicas também garantiria um processo de avaliação mais eficaz. A introdução de mecanismos de avaliação técnicos que balancem os pessoais também são importantes.

[123 - design, concorreu mas nunca teve apoio]

66 O novo regulamento deve prever, após uma primeira análise da Candidatura pelos elementos das Comissões de Apreciação, uma posterior audiência prévia com os responsáveis das estruturas, de forma a possibilitar esclarecer matérias que suscitem explicações mais precisas necessárias a uma decisão mais fundamentada. Como pode, por exemplo, a "Qualidade e Relevância Artística" ser analisada por uma Comissão que baseia o seu critério com o que vai escrito num projeto? E o Percurso Artístico Profissional? Como poderá? ser avaliado sem um conhecimento próximo da realidade em que uma estrutura trabalha e das especificidades da sua atuação? Os elementos das Comissões de Avaliação deveriam ter contato direto com a realidade de cada estrutura que se candidata, como forma de interpretarem com menos subjetividade o Plano de Atividades proposto e o historial de execução das atividades nos anos em que as estruturas receberam financiamento.

[260 - cruzamentos disciplinares, teve apoio] 
6 Deve haver clareza nos critérios e imparcialidade e fundamentação na avaliação. Devem ser reveladas as pontuações (com fundamento) de cada membro do júri e não apenas um total. Tem de haver transparência porque se trata de um concurso público para a atribuição de apoios públicos. Os membros do júri devem ter real conhecimento do terreno e serem tecnicamente competentes.

[360 - teatro, teve apoio]

6 Parece-nos incompreensível que o concurso de apoio pontual seja deliberado sem júri. O critério de avaliação das candidaturas é complexo, $\underline{A}$ ausência de uma acta avaliadora do projecto, não permite a compreensão da sua avaliação. O processo de contestação, que nos dá apenas o acesso a todas as candidaturas proponentes do mesmo patamar, coloca-nos numa posição claramente injusta e subjectiva. Somos obrigados a tirar conclusões através da comparação das propostas e, contestar a proposta de decisão, através dessa comparação, e não do processo de avaliação.

[399 - cruzamentos disciplinares, teve apoio]

\section{Comissões de acompanhamento e avaliação}

Relativamente aos projetos apoiados, o estudo incluiu uma questão aberta que procurou conhecer a experiência e apreciação das entidades relativamente às comissões de acompanhamento e avaliação ${ }^{38}$. Uma parte significativa das entidades não tem experiência direta de acompanhamento e avaliação por parte de comissões, dado o peso na amostra de entidades que nunca concorreram ou que tendo concorrido nunca obtiveram apoio. Em todo o caso, consideraram relevante pronunciarem-se neste âmbito.

A análise dos contributos evidencia que o acompanhamento e a avaliação são muito valorizados, mas devem ser revistos o papel e as competências das comissões. Em particular, o acompanhamento das atividades e o acesso das entidades às avaliações são as dimensões mais destacadas pelas entidades.

Há posicionamentos que, embora não destoem quanto à importância da avaliação, questionam se as comissões são necessárias, dando como exemplo a Fundação Calouste Gulbenkian e o Instituto do Cinema e do Audiovisual em que são solicitados relatórios e não existem estas comissões.

${ }^{38}$ Q21. As entidades beneficiárias dos apoios plurianuais são objeto de avaliação pelas comissões de acompanhamento e avaliação. Em que medida considera que são úteis para o desenvolvimento dos projetos apoiados? A taxa de resposta a esta questão é $77 \%$. 
46 Não sei, a Fundação Calouste Gulbenkian dá apoio a artistas e projectos muito bons, tem reconhecimento a nível nacional e internacional e só pede um relatório. Na verdade bem que a DGartes podia se inspirar nos modelos de apoios e concursos da Fundação Calouste Gulbenkian, estão muito adequados à realidade artística contemporânea.

[5 - artes plásticas, nunca concorreu]

6 Não tenho conhecimento para me pronunciar sobre essas comissões de acompanhamento e avaliação. No caso do cinema não existem comissões, e o acompanhamento e avaliação são feitos através de relatórios regulares obrigatórios (de trabalho e de contas) que as entidades entregam ao ICA.

[179 - outra área, teve apoio]

6 Na verdade, consideramos que não têm sido úteis, tanto quanto seria o desejável, pois existe uma inconstância muito grande nos critérios de avaliação e nos procedimentos de acompanhamento bem como na própria composição destas Comissões de Acompanhamento e Avaliação. Propomos que a própria DGArtes pudesse criar um departamento interno que apenas recebe os relatórios das estruturas apoiadas, que está disponível para assistir às estreias e que cria procedimentos internos de controlo do cumprimento do exposto nas candidaturas apoiadas. Isto é possível embora exija a contratação de profissionais destacados unicamente para esta tarefa e distribuídos por todo o território nacional.

[248 - teatro, concorreu mas nunca teve apoio]

Entre as entidades que consideram positivamente o papel das comissões argumenta-se a importância de estas conhecerem empiricamente a atividade das entidades, garantirem uma melhor gestão do financiamento público, assegurarem um melhor desenvolvimento do projeto e acompanharem, do ponto de vista técnico, a sua boa execução.

66 A avaliação e o acompanhamento dos projectos não podem ser descurados. A garantia da boa gestão dos apoios atribuídos deve ser assegurada e esta avaliação deverá guiar as estruturas para melhores desempenhos e melhores resultados.

[237- música, concorreu mas não teve apoio] 
6 São muito úteis para garantir que são realizadas as actividades programadas e caso sejam necessárias alterações ao programa estas sejam desenvolvidas de acordo com o interesse público.

[37 - teatro, teve apoio]

66 Não conheço esse trabalho, pois não recebemos nenhum apoio, mas pareceme fundamental que a DGARTES esteja ao lado das estruturas que apoia e que acompanhe o seu trabalho, não apenas porque falamos de investimento público, que deve ser fiscalizado, mas sobretudo para ajudar as estruturas a meIhorarem o seu desempenho. Ou seja, as comissões mais do que fiscalizar, devem apoiar as estruturas artísticas a desempenharem melhor o seu trabalho. Daí a importância destas comissões serem constituídas por profissionais com experiência e conhecimento real das áreas.

[412 - música, concorreu mas nunca teve apoio]

6 As comissões de acompanhamento são de extrema importância para projetos plurianuais, permitindo, através de visitas de monitorização e acompanhamento regulares, avaliar se os projetos estão a ser bem implementados. No caso de desvios as comissões poderiam também ter um papel de auxiliar as entidades a melhor atingir os objetivos propostos e a garantir a qualidade das suas atividades.

[154 - outra área, teve apoio]

66 a) As Comissões de acompanhamento são fundamentais para que os dados da DGArtes possam ser construidos a partir de um conhecimento direto da realidade e não das meras representações feitas pelos agentes. b) É imperioso que a relação entre o seu orçamento (remuneração e deslocações) e a morada/perfil das pessoas que as integram, permita efetivamente um acompanhamento in loco das atividades. c) As Comissões de acompanhamento são fundamentais para a legitimação da despesa do apoio às artes perante os contribuintes.

[209 - teatro, teve apoio]

É entre as entidades apoiadas e com experiência de relação com as comissões que os posicionamentos são mais contrastantes, entre as que consideram muito positivamente o trabalho desenvolvido pelas comissões e as que salientam a sua ineficácia.

As entidades que afirmam ter tido uma experiência positiva enfatizam o seu papel na articulação com a DGArtes, mas também reconhecem as suas limitações de meios. 
46 Este é o 1ำ ano que tenho comissão de acompanhamento. São muito úteis pois humanizam o contacto com a DGArtes e criam uma relação de proximidade.

[205 - artes digitais, teve apoio]

66 São fundamentais na lógica construtiva da relação com a DGArtes. Da experiência que tenho a este nível, entendo que o desempenho do papel das comissões de acompanhamento e avaliação tem sido excelente. Sinto que acompanham projetos a mais e que não Ihes podem dar a devida atenção. Naturalmente que uma candidatura que pede dados excessivos depois também tem que analisar dados excessivos. Isto torna demasiado contraproducente o processo pois este foca-se demasiado nos aspetos burocráticos e menos nos aspetos artísticos.

[42 - música, teve apoio]

6 Consideramos que são extremamente úteis e que, inclusivamente, deveriam ser reforçadas estas comissões, nomeadamente no que diz respeito à sua composição e recursos, no sentido de permitir um mais efetivo e aprofundado acompanhamento das atividades das estruturas. Acreditamos que estas comissões são úteis na medida em que dotam os projetos apoiados de interlocutores do Estado; obrigam as estruturas a manter coerência e rigor dos contratosprograma assinados; privilegiam uma relação dialética entre o Estado e os agentes culturais; contribuem para a identificação de situações anómalas, ilegalidades ou simples aspetos a melhorar. E, finalmente, reportam à tutela a realidade do setor.

[506 - teatro, teve apoio]

64 As comissões de acompanhamento são muito definidas pelas pessoas que as compõem. A nossa experiência tem sido a esse nível frutífera. As comissões que nos têm calhado em sorte fazem um acompanhamento regular e informado da nossa actividade. Consideramos que esse acompanhamento será mais útil à DGArtes do que à Associação. Nós não temos acesso aos relatórios produzidos pela Comissão de acompanhamento, reduzindo a comissão à função de fiscal da DGArtes, sem consequências palpáveis e utilizáveis pelas entidades. Tal como com a instituição que as nomeia, também com as comissões queremos estabelecer um diálogo que permita melhorar o nosso trabalho, que nos ajude, com o seu olhar atento, a ponderar os caminhos possíveis.

[529 - teatro, teve apoio]

6 São importantes se conseguirem efectivamente acompanhar os projetos. A este nível tem-se verificado alguma irregularidade na presença dos elementos das comissões. Actualmente, por exemplo, esta presença tem sido bastante 
frequente. Era importante que para além dos espectáculos da companhia pudessem acompanhar outras actividades desenvolvidas de forma a ficarem a conhecer a totalidade do protejo e as especificidades da abordagens.

[522 - teatro, teve apoio]

Entre as entidades que evidenciam uma experiência negativa das comissões, é muito significativo o número das que afirma não ter qualquer acompanhamento ou ter um acompanhamento muito residual por parte das respetivas comissões. Importa salientar que diversas referem uma melhoria recente do acompanhamento por parte das comissões.

6 Honestamente, não nos apercebemos da existência ou presença das comissões de acompanhamento e avaliação, a não ser através da exigência regular de relatórios e justificações. Tal como referimos nas respostas às questões 16, 17 e 18, sentimo-nos sozinhos e sem qualquer acompanhamento. Consideramos, sim, que deveria ser obrigatória a presença de um elemento da DGArtes nos nossos espetáculos e no nosso teatro, que testemunhasse o nosso trabalho e, inclusivamente, nos desse sugestões para potenciar e otimizar futuras candidaturas. Gostaríamos de ter na DGArtes uma entidade parceira e não apenas uma entidade vigilante.

[264 - teatro, teve apoio]

66 Extremamente útil, sendo que a nossa experiência é que estas comissões de avaliações têm tido um papel muito residual, ficando-se pelo acompanhamento de uma ou duas atividades por ano.

[903 - cruzamentos disciplinares, teve apoio]

G6 É fundamental a existência das comissões de acompanhamento e avaliação desde que funcionem. Conforme a nossa experiência - só este ano fomos contactados pelos elementos da comissão de acompanhamento e avaliação para 2017. Nos anos anteriores, nunca nos contactaram, nem sabemos quem eram. As Comissões de Acompanhamento e Avaliação são úteis para o desenvolvimento dos projectos apoiados - para tal tem que existir um acompanhamento real - desde o pedido de apoio para as actividades até à sua realização.

[290 - teatro, teve apoio]

6 Consideramos que as comissões de acompanhamento e avaliação são de extrema importância. Infelizmente neste momento a nossa sensação é que estas são quase inexistentes. A nossa comissão de acompanhamento do Tripartido 
[...] para 2015/2016 foi atribuída no ultimo mês do ano de 2016, o que obviamente significa que praticamente todas as actividades foram feitas sem acompanhamento, o que na nossa opinião não deveria acontecer.

[114 - artes plásticas, teve apoio]

6

Não vimos sentido algum nestas comissões. Em 17 anos apenas uma vez alguém dessa comissão esteve presente na nossa actividade. Nunca nos foi enviado qualquer comentário ou relatório dessa comissão. Achamos que é um gasto adicional que poderia ser canalizado para os apoios. As entidades têm de enviar relatórios (agora até intercalares) e provas do desenvolvimento da actividade. Havendo estas comissões dá a sensação que há duvida no trabalho desenvolvido.

[118 - música, teve apoio]

66 Achamos que o acompanhamento à execução das acções deverá ser privilegiado, a estrutura já beneficiou de um apoio bienal, pontual e anual (com prorrogação em 2016/2017) e nunca teve nenhuma visita de uma comissão de acompanhamento e avaliação, acreditamos que esse processo de partilha é essencial e não deverá ser preterido face à obrigatoriedade de apresentação dos relatórios. É importante que a comissão de acompanhamento seja constituída por elementos com experiência na área, tanto na área artística como na área de gestão de projecto para que de facto o acompanhamento possa ser útil para ambas as partes.

[245 - teatro, teve apoio]

O principal aspeto de melhoria presente nos diversos contributos é o da necessidade de reforçar a dimensão do acompanhamento, com maior regularidade e conhecimento empírico do trabalho desenvolvido pelas entidades.

6 Da forma que operam, as comissões de acompanhamento e avaliação são pouco ou nada úteis à entidade apoiada e ao desenvolvimento dos seus projectos. A sua acção devia ser mais próxima da entidade e dos projectos e a sua atitude não ser meramente fiscalizadora. Sugere-se pelo menos 2 reuniões da entidade apoiada com a comissão durante o período de vigência do apoio, que sirvam para aferir/comunicar/aprovar/rejeitar eventuais alterações que decorram do cumprimento do plano de actividades e orçamento previstos, e suas razões, antes da respectiva aprovação e correcção na plataforma electrónica. Neste sentido, os antigos relatórios intercalares, em vez de serem mais um passo burocrático (felizmente já não solicitado) passam a ser momentos de troca entre a entidade e estes intermediários (as comissões).

[481 - dança, teve apoio] 
66 Como referido, se as comissões tivessem um papel construtivo e de acompanhamento, se pudessem partilhar as suas opiniões e dar-nos um feed back poderiam realmente apoiar o desenvolvimento de projetos. $O$ facto de nem sequer termos acesso aos seus relatórios parece-nos grave. A REDE tem uma proposta que passo a citar: a) Deve ser revisto o papel e competências das atuais comissões de acompanhamento, nomeadamente garantindo o envolvimento direto de uma equipa especializada nos projetos, numa perspetiva de aconseIhamento processual e apoio e não apenas numa perspetiva de verificação. b) Estas comissões devem acompanhar os projetos apoiados numa lógica de colaboração ao longo de todo o processo e em várias áreas: clarificação dos procedimentos, alterações, relatórios, gestão da plataforma, etc. c) Deve estar garantida a sua competência, capacidade de resposta e autonomia de articulação com as estruturas. d) Estas comissões devem ser constituídas por especialistas das diferentes áreas artísticas e de gestão cultural e ter uma função mediadora e facilitadora no desenvolvimento e controlo da implementação dos projetos, para além de poderem desempenhar um importante papel na recolha e sistematização de informação sobre os projetos. e) As comissões devem ter um número adequado de projetos a seu cargo de forma a permitir a proximidade e acompanhamento no terreno. f) As comissões devem estar organizadas em células distribuídas pelo território. g) A existência destas comissões pode aumentar, de forma menos burocratizada, a capacidade de resposta do organismo responsável pelo sector das artes e o alargamento da sua ação a todo o território, não invalidando uma interlocução direta com o mesmo.

[479 - dança, teve apoio]

6

Deve existir um reforço destas comissões de acompanhamento e avaliação, e elas devem, durante o apoio, centrar-se muito mais no acompanhamento do que na avaliação. Ou seja, devem ter um papel de esclarecimento, de estudo de soluções em conjunto com as entidades para problemas inesperados. Estas comissões deveriam desempenhar um papel essencial também no aconselhamento sobre a gestão financeira das diversas entidades, alertando para desvios orçamentais e para situações ilegais de contratação. Estas comissões serão tanto mais úteis quanto mais comissários existirem, ou seja, quanto mais personalizado e presente for o seu trabalho de acompanhamento. Quanto à avaliação, porque ela é naturalmente inevitável e desejável, deve ser clara, servir para ponderação de futuros apoios, podendo ter até uma percentagem fixa para essa ponderação.

[242 - teatro, nunca concorreu]

46

Serão úteis se efectivamente acompanharem a actividade das estruturas, assistirem aos espectáculos e às outras actividades e se dispuserem a falar com elas para perceberem em que condições desenvolvem o seu trabalho. Os seus relatórios devem ser tornados públicos e devem ser tidos em conta na avaliação de futuras candidaturas das entidades apoiadas. Até ao momento, ne- 
nhuma comissão de apreciação fez o trabalho assim em relação à nossa estrutura. Talvez a mais recente comissão de acompanhamento o venha a fazer. As duas pessoas que a compõem já assistiram a mais actividades [da entidade] em dois meses do que todas as restantes comissões de apreciação em seis anos.

[498 - teatro, teve apoio]

Do conjunto das propostas de melhoria do trabalho das comissões destacase ainda a necessidade de dar às entidades acesso às avaliações produzidas pelas comissões de acompanhamento.

66

Em teoria, estas comissões são uteis pois implicam um acompanhamento do trabalho realizado e uma verificação do cumprimento dos contratos. Porém, os relatórios devem ser partilhados com as companhias com vista a uma maior transparência no processo e para que possam constituir um contributo útil para boas práticas. É importante que haja diálogo com as companhias. Em relação ao caso da nossa companhia, nunca nos foi facultado o acesso a qualquer relatório, nem do quadriénio 2009-2012 nem referente a 2013-2016.

[360 - teatro, teve apoio]

66 Por outro lado, as comissões deveriam fornecer às estruturas cópia dos relatórios de avaliação de modo a não funcionarem apenas como mecanismo de controlo, para a DGArtes, mas também de elemento de percepção de como a programação/criação desenvolvida é valorizada pelos técnicos e posterior direito de resposta ou correção de aspectos negativos, por parte das estruturas.

[462 - artes plásticas, teve apoio]

6 Temos alguma reticência relativamente à comissões de avaliação, porque não existe um dialogo de acompanhamento mas sempre de urgência e fugazes porque têm demasiados projectos a acompanhar. Estas comissões deveriam não só acompanhar projectos mas terem outro papel a nível de compreenderem a dimensão dos projectos nas cidades em que se inserem. Em vez de inspectores poderiam ser propulsores para estas entidades. Estas comissões teriam que ser mais alargadas e acompanharem os projectos de raiz. Existe alguma dúvida relativamente à seleção de alguns elementos da comissão de avaliação porque achamos que não reunem o curriculum necessário para fazerem este género de acompanhamento. Penso que esta comissões poderiam não ser só de avaliação mas poderiam ter um papel maior a nível da dinamização de sessões de trabalho com as entidades para existirem mais modos colaborativos e de partilhas de preocupação de programação cultural entre as entidades. Já que as comissões de avaliação têm um conhecimento alargado do que acontece na 
região seria excelente difundi-lo do que afunilar numa avaliação que irá para os arquivos sem ver a luz do dia.

[514 - cruzamentos disciplinares, teve apoio]

66 O acompanhamento e avaliação das entidades apoiadas é um fator fundamental para garantir a boa prossecução dos projetos. Neste sentido é fundamental definir e clarificar de que forma deverá ser feito este acompanhamento e esta avaliação. Julgamos que se deve estabelecer um conjunto de reuniões periódicas entre as entidades e a comissão nas quais possam ser discutidos procedimentos, problemas e soluções que contribuam para um bom desempenho do trabalho das entidades e da DGArtes. As comissões devem também acompanhar o trabalho realizado e pedir esclarecimentos às entidades sempre que o considerem necessário, no sentido de produzirem um relatório anual, ou dois semestrais, fiável e informado. Estes relatórios devem ser partilhados com as entidades e deverão ser tidos em linha de conta na avaliação das entidades e nas candidaturas futuras. Para que este processo possa funcionar é necessário que as diversas comissões concluam os seus trabalhos e funcionem plenamente. A título exemplificativo verifica-se que até à data nunca tivemos acesso a nenhum relatório das comissões, nem tão pouco sabemos qual o peso da informação veiculada nesses relatórios na avaliação do trabalho plurianual desenvolvido e a desenvolver.

[273 - teatro, teve apoio]

66 Nunca recebemos essas avaliações por parte das Comissões de Acompanhamento. Não fazemos a mínima ideia do que sobre o nosso trabalho opinaram. Portanto nunca nos serviram para nada. Nem sequer (seria o mínimo) para nos podermos justificar ou exercer direito de resposta sobre essas apreciações e se se justificasse. Mas seria muito útil ter acesso a essa informação, naturalmente.

[147 - teatro, teve apoio] 


\section{Relação entre a entidade e as direções regionais de cultura}

Relativamente à relação da entidade com as DRC, incluíram-se três questões abertas $^{39}$ que procuram de modo articulado identificar: i) a experiência atual e anterior das entidades com as DRC; ii) o tipo de resposta obtida por parte dos serviços; iii) os contributos relativamente ao papel futuro que as DRC devem vir a desempenhar.

\section{Relação com as DRC}

A maioria das entidades menciona não ter qualquer relação, ou não ter experiência suficiente com as DRC que permita pronunciar-se (68\%). Em seguida, no conjunto das entidades que afirmam ter relação com as DRC, o posicionamento mais frequente consiste em considerar a relação com as DRC como positiva ou globalmente positiva (20\%). As posições que caracterizam negativamente a experiência com as DRC (maioritária ou exclusivamente) representam cerca de $12 \%$.

Entre as entidades que invocam não ter qualquer experiência com as DRC salientam-se as da região de Lisboa e Vale do Tejo, na qual não existe DRC, sendo as suas atribuições e competências para este território assumidas pela DGArtes. Têm origem também em entidades de menor dimensão (medida pelo orçamento de 2016) e com uma relação de menor proximidade com o modelo de apoio às artes (nunca concorreu ou concorreu, mas nunca teve apoio). Consideram ainda que as DRC não têm atualmente apoios e competências que justifiquem a relação.

66 Estando inseridos na Região de Lisboa e Vale do Tejo, o nosso contacto é directo com a DGArtes.

[118 - música, teve apoio]

\footnotetext{
${ }^{39}$ Q22. As DRC são intervenientes nos processos de apoio às artes geridos pela DGArtes, nomeadamente nas decisões sobre acordos tripartidos, apoio nas audiências de interessados e participação nas comissões de acompanhamento e avaliação. Como descreve a relação da entidade com as DRC? A taxa de resposta é $71 \%$.

Q23. Como tem sido a resposta por parte das DRC? A taxa de resposta é $62 \%$.

Q24. Como gostaria que, no futuro, venha a ser o papel das DRC nos processos de apoio às artes? A taxa de resposta é $70 \%$.
} 
6 Não se aplica. No nosso caso, comunicamos directamente com a Câmara. É simples e eficaz.

[322 - teatro, nunca concorreu]

6 No momento atual torna-se difícil emitir uma opinião, tanto mais que no quadro deste último quadriénio as DRCs passaram por várias situações, na medida em que dependem diretamente do poder central. As tarefas, embora possam estar definidas, não contam com poder de decisão. O caso das comissões de acompanhamento dos últimos anos pode bem ilustrar essa realidade. Acresce, que desde o decreto-lei de 2008 que as delegações regionais deixaram de desempenhar qualquer papel que solicitasse uma relação direta com as entidades.

[175 - teatro, teve apoio]

64 A relação que temos com a DRCC é bastante vaga, uma vez que muitas vezes a informação parece não circular entre a DGArtes e as delegações Regionais, tendo as próprias muitas dificuldades em resolver-nos questões que se levantam a diário, seja com a plataforma, subsídios, entre outras. Como já referimos anteriormente, gostaríamos que as DRCs pudessem ter um papel mais importante neste processo, sobretudo no acompanhamento e reconhecimento das entidades.

[325 - cruzamentos disciplinares, teve apoio]

No conjunto das entidades que têm alguma relação com as DRC, salienta-se uma relação caracterizada positivamente e que, em alguns casos, procura evidenciar a falta de meios (financeiros e humanos) das DRC. Os aspetos negativos que recolhem mais contributos prendem-se com a fraca proximidade, conhecimento do projeto artístico e participação nas iniciativas da entidade.

De salientar que, independentemente de posicionamentos mais ou menos críticos, uma parte significativa das entidades reconhece o papel relevante das DRC na relação com as entidades artísticas e com os territórios. Diversos posicionamentos consideram que a relação com a DRC não tem sido suficientemente promovida nem estimulada.

\section{Experiências positivas}

Os posicionamentos que identificam uma relação positiva com as DRC consideram muito importante o papel das DRC, e esta valorização está particularmente presente entre as entidades sediadas fora da Área Metropolitana de Lisboa. Os 
argumentos mobilizados enfatizam a proximidade e o conhecimento privilegiado que as DRC têm do território e do seu projeto. Em termos gerais, caracterizam de forma positiva a experiência de relação com as DRC e consideram que o seu papel deve ser reforçado.

6

Excelente. Desde sempre. Não temos tido qualquer dificuldade com a nossa direcção regional e já mudou de representante várias vezes. É um parceiro importante e no caso da do [...] fundamental, já que o território é enorme e sempre com o mesmo objectivo dos agentes, melhorar e criar condições para o trabalho na área. Alerto ainda que são elas que melhor conhecem os agentes e a sua importância territorial pelo que não faz sentido só serem chamadas nos tripartidos deveriam solicitar sempre o seu parecer mesmo que este tivesse uma majoração não muito elevada.

[52 - música, nunca concorreu]

6 Muito positiva pelo esforço que sentimos por parte DRC[...] em fazer o acompanhamento ao nosso projeto, estando por dentro do trabalho das entidades. Apesar disso a falta de pessoal nas DRC[...] é sentida pela nossa parte, pois não estão tão presentes nas nossas atividades quanto manifestam querer.

[154 - outra área, teve apoio]

6 Positiva. A Direção Regional da Cultura [...] tem estado sempre presente nas relações entre a [nossa entidade] com o território e com outras entidades públicas. Admite-se, também, que tem sido um mediador entre a nossa instituição e a administração central. Poderá dizer-se que é um facilitador. Ainda assim, pensamos que a sua linha de ação poderia ser reforçada num espírito de descentralização cultural.

[269 - artes plásticas, teve apoio]

6 A nossa situação é peculiar, porque embora estejamos sediados em Lisboa, grande parte do nosso trabalho realiza-se [num município do Alentejo], cuja autarquia já está envolvida num tripartido. Sentimos mais apoio e acompanhamento da DRC[...] do que da Dgartes. Não cremos que seja importante a sede para a execução do trabalho. Por isso estendemo-nos por vários lugares(...) Seria bom que o trabalho da direcções regionais fosse mais pautado pelo trabalho realizado nas regiões do que pela sede da estrutura!

[286 - teatro, teve apoio]

6 De um modo geral muito positiva. Sempre encontrámos abertura para a auscultação das nossas preocupações e bom acolhimento no sentido de colaborar 
na solução das problemáticas expostas, afirmadas ou emergentes. Independentemente do modelo de relação com a tutela (e, no nosso caso, ele tem sido diversificado) sempre encontrámos, em geral, muito bom acolhimento à exposição do sentido das nossas preocupações e da nossa argumentação e, em alguns casos, mesmo aperfeiçoando-a.

[427 - teatro, teve apoio]

\section{Experiências negativas}

Os posicionamentos que salientam aspetos negativos na relação com as DRC sublinham principalmente o facto de ser uma relação institucional predominantemente distante e pontual. Encontra-se aqui uma articulação muito próxima entre os aspetos menos positivos identificados na relação com a DGArtes e os identificados na relação com as DRC. A fundamentação para posicionamentos mais críticos assenta na fraca articulação das DRC com as entidades no território, a pouca proximidade entre as DRC e as entidades, a falta de reuniões, de conhecimento acerca da entidade e do seu projeto artístico e a fraca participação nas iniciativas promovidas.

Considera-se, por outro lado, que há falta de recursos humanos e de preparação específica dos técnicos a diferentes níveis.

Em relação ao papel das DRC, uma parte significativa das entidades aponta uma falta de definição das competências específicas destes organismos, os seus limitados poderes de decisão e meios (financeiros e humanos).

Identificam-se ainda dificuldades de elegibilidade para os apoios nas entidades que tendo sede numa região, desenvolvem projetos noutra região e/ou de âmbito nacional.

6 As DRCs encontram-se, do nosso ponto de vista, esvaziadas de poder. Deveria ser encontrado um outro modelo de trabalho que assegurasse a definição da sua função especifica e das suas competências e estratégias de intervenção

$$
\text { [410 - teatro, teve apoio] }
$$

6 Consideramos que as DRCs deveriam ser mais consideradas e intervenientes nos processos. Deveria existir no júri um elemento por região com parecer sobre os projetos da sua região. O acompanhamento deveria ser feito pelas DRCs.

$$
\text { [98 - dança, teve apoio] }
$$


66 A participação das DRCs nas atividades das estruturas é escassa, o seu envolvimento em reflexões sobre os apoios às artes e sobre o planeamento dos territórios artísticos é praticamente inexistente. As comissões de acompanhamento e avaliação concentram-se em assistir aos resultados das atividades das estruturas em vez de as conhecerem "por dentro", pensarem sobre o seu funcionamento e darem feedback construtivo.

[335 - dança, concorreu mas nunca teve apoio]

64 A relação entre nós e a DRC[...] tem sido positiva. É de salientar que o orçamento disponível a concurso público na DRN[...] é insignificante (uma média de 20.000 euros anuais para um único concurso para todas as entidades da zona Norte), o que torna os valores dos apoios concedidos insignificantes. Acresce ainda que muitas vezes é dada prioridade a entidades culturais e artísticas de carácter não profissional. Seria importante que as DRCs conhecessem pessoalmente as estruturas e o seu trabalho artístico, sendo também mediadores no território para a realização de parcerias entre estruturas. Nós, enquanto entidade do Norte a realizar um projecto, por exemplo na região Centro, não estando abrangidos por essa DRC não nos é possível apresentar nenhuma candidatura. Simultaneamente, a DRC[...] não nos apoia um projecto a ser realizado/apresentado noutra região, alegando que não é da sua competência. Assim, a solução para quebrar este impasse seria que, no mínimo, as DRCs pudessem apoiar todos os projectos realizados/apresentados na sua região mesmo que encabeçados por entidades com sede em regiões diferentes.

[489 - cruzamentos disciplinares, teve apoio]

\section{Resposta por parte das DRC}

Ainda no que diz respeito à relação com as DRC, solicitou-se às entidades que se pronunciassem sobre a experiência de resposta obtida por parte deste organismo ${ }^{40}$. A maioria das entidades afirma não ter relação com as DRC e/ou não ter experiência suficiente que permita responder. Entre estas, as da região de Lisboa e Vale do Tejo.

No conjunto das entidades que têm uma experiência de relação verifica-se uma resposta estreitamente articulada com a questão anterior.

Uma parte das entidades considera positivo o apoio recebido, tendo em conta as limitações reconhecidas das DRC. Outra, identifica diversas limitações na resposta das DRC. A fraca participação nas iniciativas e o desconhecimento da entidade e do seu projeto artístico traduzem uma boa parte dos contributos. Identifica-se também, em geral, a falta de meios financeiros e humanos para

${ }^{40}$ Q23. Como tem sido a resposta por parte das DRC? A taxa de resposta é $62 \%$. 
dar resposta às necessidades das entidades. Os posicionamentos são ainda críticos da fundamentação avançada pelas DRC para justificar a falta de apoios, designadamente invocar a escassez de verbas e recursos e/ou remeter os apoios para as câmaras municipais ou para a tutela.

Outro aspeto mencionado de forma transversal é a falta de preparação dos técnicos, designadamente para dar apoio adequado às candidaturas aos concursos. No plano da comunicação, destacam ainda a informação insuficiente e falta de apoio na divulgação de iniciativas.

66 A melhor possivel dentro das limitações orçamentais e de funcionamento das mesmas. É uma equipa super competente com real interesse pelo trabalho da entidade, conhece o terreno, as dificuldades, as estruturas e o público.

$$
\text { [437 - teatro, teve apoio] }
$$

\section{6}

Penso que começam a ter o cuidado de estarem mais presentes e de estarem mais informados. O turismo e as artes caminham lado a lado, consequentemente, há uma adaptação do papel das DRCs.dentro do contexto de internacionalização da cultura e das artes e do turismo,...há novas formas de criar; há novos públicos há outras necessidades, etc...faz com que por parte da DRCS haja mais responsabilidade, mais interesse em serem mais participativos e em fazerem coisas com mais qualidade.

$$
\text { [104 - cruzamentos disciplinares, nunca concorreu] }
$$

6

Há sempre uma resposta adequada e atenta. Ultimamente não tem havido necessidade de contactos mais diretos, sobretudo devido às facilidades da informática permitindo uma resposta mais imediata às dúvidas e diversos problemas levantados, junto dos Serviços Centrais da DGArtes. Não obstante - e sobretudo através das comissões de acompanhamento e avaliação (que durante o último ano deixaram de funcionar, problema que, no final de 2016, foi resolvido) -, o apoio tem sido muito positivo.

[143 - música, teve apoio]

6

Todas as artes profissionais, com apoio directamente da Tutela, deveriam estar visceralmente ligadas à DGArtes. Tudo o que seja amador - e aqui temos um mundo de actividades, como: corais, tunas, bandas, música popular, música ligeira, grupos de folclore e etnografia - orfeões, cânticos e cantares - escolas populares de música - artesanato - grupos amadores de teatro (tão abandonados nos últimos anos) escolas dramáticas, grupos culturais, recreativos e confrarias c/ iniciativas culturais, etc, etc. ligadas às Direç̧ões Regionais da Cultura

[161 - teatro, teve apoio] 
66 Em projetos criados fora da sede da Associação, já algumas vezes foram estabelecidos contatos com a Direção Regional de Cultura [...]. Existe já entre a estrutura e a DRCA uma relação de confiança e parceria que se tem vindo a desenvolver de forma muito positiva, ainda que pontualmente.

[371 - teatro, teve apoio]

6 Tal como afirmamos em relação à DGArtes, o relacionamento institucional é positivo e neste caso com visita das comissões de acompanhamento ou na apresentação de espectáculos realizados pela companhia.

[426 - teatro, teve apoio]

66 Reconhecidamente, tem sido pautada pelo necessário rigor, com espírito cooperante e comedidamente interventivo, designadamente, em instâncias decisórias regionais (tais como autarquias, por exemplo; mas também em instâncias centrais) ajustando discurso e entendimento propício à consecução dos objectivos inerentes à acção desta estrutura. Tem sido uma relação respeitosa, cuja amplitude cultural e política muito valorizamos. Neste aspecto, em geral (salvo numa única excepção, já antiga), temo-nos sentido sempre muito bem acompanhados na consecução dos nossos objectivos artísticos e culturais.

[427 - teatro, teve apoio]

6 As DRCs não têm os meios financeiros e humanos para poderem atender às questões e necessidades dos agentes culturais. Nomeadamente a DRC[...] vêse, na maior parte das vezes, incapacitada por falta precisamente dos meios acima referidos.

[37 - teatro, teve apoio]

6 Não tem havido qualquer comunicação. Apesar dos convites que sistematicamente fazemos para conhecerem o nosso trabalho, nunca foram capazes sequer de comparecer em 8 anos de atividade.

[488 - teatro, teve apoio]

6 Entendemos que esses serviços têm sempre sido exercidos diligentemente, embora se note um razoável desfasamento devido à falta de continuidade e de ligação entre as diferentes e diversas entidades. Nos últimos anos têm sido demasiadas as mudanças para que os serviços possam criar massa crítica quanto aos assuntos em causa.

[175 - teatro, teve apoio] 
6 A resposta é sempre pronta e existe sempre uma grande disponibilidade para passar o máximo de informação possível. No entanto, nem todos os técnicos da DRC possuem um conhecimento total do modelo de funcionamento de apoio às artes.

[502 - teatro, concorreu mas nunca teve apoio]

66 Normal e adequada, considerando a escassez de meios com que se confrontam.

[228 - música, teve apoio]

66 Talvez porque o território que corresponde à DRC[...] seja vasto e as estruturas inúmeras, estamos em crer que o que foi dito atrás sobre a escassez de recursos humanos e financeiros na DGArtes (...) seja aqui aplicável e que isso obste a um cabal e eficaz cumprimento de objectivos, e se torne factor determinante para esse desconhecimento. $O$ facto de estar sediada em Vila Real também não ajuda ao mútuo aprofundamento da relação.

[229 - teatro, teve apoio]

66 No que diz respeito ao apoio nas audiências de interessados e ao poder decisório das DRCs e, concretamente no que concerne à DRCN, convém frisar que os técnicos deste organismo deveriam conhecer melhor o projeto de cada estrutura artística que lhe está adstrita, por forma a terem dados concretos para poderem elaborar relatórios e avaliar com isenção no momento de decisão [...].

[432 - teatro, teve apoio]

\section{Papel futuro das DRC}

O estudo procurou ainda conhecer a opinião das entidades relativamente ao papel futuro a desempenhar pelas $\mathrm{DRC}^{41}$. Em termos gerais, as entidades defendem maior autonomia e poder de decisão por parte das DRC, maior delimitação de competências face à DGArtes e a redefinição de uma estratégia de intervenção para as DRC e para os territórios.

Uma parte das entidades considera que é essencial uma participação mais ativa nos mecanismos de atribuição dos apoios nacionais que passa, por exemplo, por integrar os painéis dos apoios nacionais ou pela elaboração de documentos estratégicos de apoio à decisão. Assim como pelo acompanhamento e

41 Q24. Como gostaria que, no futuro, venha a ser o papel das DRC nos processos de apoio às artes? A taxa de resposta é $70 \%$. 
avaliação do impacto dos projetos apoiados nos territórios. No entanto, a assumir este papel, as DRC devem ser dotadas de recursos humanos com habilitações adequadas. Num quadro futuro de alargamento de competências, defendem assim maior qualificação e experiência do sector por parte dos técnicos das DRC.

Propõe-se que as DRC assumam um papel de maior articulação entre a DGArtes e as entidades, bem como com as câmaras municipais, juntas de freguesia e outros parceiros no território.

De forma transversal, os posicionamentos vão no sentido de atribuir um papel mais ativo às $\mathrm{DRC}$ na promoção das entidades e dos seus projetos, defendendo uma estratégia de maior proximidade com as entidades (maior participação em iniciativas, promoção de sessões de esclarecimento e apoio às candidaturas regionais e nacionais e reuniões regulares).

Gostariam ainda que as DRC assumissem um papel mais ativo no mapeamento, informação e capacitação dos agentes culturais da região, bem como na dinamização e identificação das necessidades dos territórios e que com isso contribuísse para a redução das assimetrias regionais.

Encontram-se ainda posicionamentos que defendem um maior apoio a entidades e projetos que não se enquadrem no modelo de apoios da DGArtes.

De um modo geral, consideram esta questão relevante, solicitando a promoção de um debate alargado sobre a descentralização cultural e o papel das DRC e demonstram-se disponíveis para contribuir para uma mais aprofundada definição do seu papel.

6 Acredito que possa ter mais relação mas existe necessidade de garantir equipas competentes para o fazer.

[32 - dança, teve apoio]

66 Pensamos que o funcionamento das Direções Regionais deveriam ser repensados. Não percebemos bem quais os seus objetivos e a sua atuação, que sentimos como inexistente. As Direções Regionais poderiam ter um papel fundamental, sendo um elo de ligação entre as entidades e as DGARTES. Tomando como exemplo a região Centro, esta é enorme e diferente entre si. A região Centro Litoral apresenta dinâmicas culturais muito distintas do Centro Interior, o mesmo se passa do Centro Norte para o Sul. Isto implica necessidades e lógicas muito diferentes. A Direção Regional deveria ter um conhecimento efetivo, no terreno das estruturas existentes, do seu trabalho e das suas necessidades. A sua ação deveria ir além dos processos de apoio às artes instituídos pela 
DGARTES, podendo ter alguma autonomia para gerir alguns e implementar algumas medidas de apoio destinadas apenas às suas regiões.

[510 - cruzamentos disciplinares, concorreu mas nunca teve apoio]

66 O seu papel é fundamental se quisermos criar um verdadeiro plano nacional de circulação de espectáculos e de fixação de entidades fora dos grandes centros. As DRCs mais facilmente poderão motivar entidades estatais e privadas locais para o apoio e divulgação a entidades que desejem aí apresentar-se ou mesmo fixar-se. Será no entanto primordial nunca esquecer que é à administração central que cabe o apoio às artes.

[242 - teatro, nunca concorreu]

66

Gostaríamos que as DRCs fossem parte integrante dos respectivos júris.

[37 - teatro, teve apoio]

6 [As DRC] deveriam ser chamadas a dar parecer sobre os projectos e deveria ser criado um programa próprio itinerante em cada um das zonas de intervenção na alçada destas direç̧ões que não só permitisse levar os projectos a todas as localidades como pudesse dar dinâmica cultural aos monumentos que estão sob a alçada destas direcções regionais

[52 - música, nunca concorreu]

66 Parece-me importante que as DRCs tenham um papel mais decisivo na atribuição dos apoios e no acompanhamento e avaliação dos projetos das suas regiões. Para alem disso, as DRCs deveriam ter no seu orçamento verbas destinadas a apoiar projetos locais que não consigam ser enquadrados nos programas da DGArte.

[57 - cruzamentos disciplinares, teve apoio]

64 As DRCs deveriam ser agentes mediadores entre o poder central e o local. Contribuindo continuamente para o estreitamento dessas relações, teriam que apoiar os territórios de forma mais direta e próxima, estando disponíveis para se envolverem no desenvolvimento artístico de cada região e encontrando medidas para esbater assimetrias.

[335 - dança, concorreu mas nunca teve apoio] 
66 As DRC's devem facilitar sessões de apoio e esclarecimento às candidaturas e sua legislação. Desta forma as entidades interessadas seriam capazes de apresentar candidaturas mais fortalecidas não estando apenas dependentes da sua própria interpretação e da sua estrutura enquanto organização.

[102 - arquitetura, nunca concorreu]

66 Gostaria que estas entidades, por estarem distribuidas a um nível local (ao contrario da DGArtes ou do Ministério da Cultura, que são orgãos únicos) possam ajudar com a formação para concursos, oportunidades, cursos internacionais, apoios Europeus, etc

[115 - teatro, concorreu mas nunca teve apoio]

66 Gostaríamos que a DRC [...] tivesse um papel mais moderador no relacionamento com as diversas entidades concorrentes. Promovendo, por exemplo, reuniões em que se poderiam coordenar datas e programas menos coincidentes, no interesse do público que é comum às diversas propostas.

[143 - música, teve apoio]

6 Uma potencial descentralização das responsabilidades da DGArtes para as DRC não deve colocar em risco iniciativas com características nacionais. No entanto somos a favor de uma distribuição mais equitativa dos fundos, nomeadamente com uma participação das DRC na atribuição dos fundos.

[144 - artes plásticas, teve apoio]

6 Só conhecendo o Algarve, tenho a dizer que a DRC[...] tem sido fundamental para a manutenção de algum desenvolvimento artístico nesta região país. Tem como missão dar apoio apenas às associações sem fins lucrativos, sejam elas compostas por artistas amadores ou profissionais, e neste segundo caso, desde que não tenham apoio da DGArtes. Ora, nós profissionais das artes nesta região, todos com associações sem fins lucrativos, não existiríamos sem a DRC[...]. Muitos poucos de nós conseguiram apoio da DGArtes e passaram para outro patamar. Sem o desenvolvimento proporcionado pela DRCA, o $365 \mathrm{Al}-$ garve nunca teria conseguido apresentar 1000 eventos programados em menos de 2 meses... Por isso acho que a DRCA deveria ser ainda mais fortalecida, ter mais orçamento, e continuar seu trabalho de proximidade com associações e artistas. Acredito que o mesmo seja verdade para as outras DRCs.

[162 - cruzamentos disciplinares, concorreu mas nunca teve apoio]

6 pensamos que o papel das DRC deve ser reforçado e cada vez mais de proximidade com as Associações e Instituições que trabalham num território. Entendemos que haja um percurso e metas definidas pelo estado como nacionais, 
mas as diferenças entre as regiões são abissais e é cada vez mais importante que isso seja tido em conta aquando da definição de apoios. As prioridades nacionais não devem sobrepor-se às locais nem às regionais, e é esse o sentido para o qual devemos caminhar - uma relação de proximidade, de confiança, de companheirismo entre as entidades e as direções regionais de cultura. Só as DRC permitem o reequilíbrio da atividade cultural do país, que infelizmente está centralizada em Lisboa e no Porto. Só as DRC podem conhecer o terreno, no dia-a-dia, e acompanhar o desenvolvimento de projetos, bem como a sua pertinência. A elas caberia reunir frequentemente com as entidades de forma a perceber quais as preocupações, prioridades e dificuldades, bem como por as entidades de uma região em contacto e cooperação permanentes. Numa fase seguinte, as DRC devem ler os projetos, reunir com as entidades sobre eles, permitir-se optimiza-los e torna-los mais pertinentes para a região. Num último momento, apoiar a sua implementação com o elevado conhecimento da área. A posteriori, avaliar o projeto em conjunto com a entidade.

[343 - teatro, nunca concorreu]

\section{Articulação entre administração central e local}

O papel da administração local no sistema de apoio às artes é abordado em três questões ${ }^{42}$ do inquérito, sobre: a experiência até ao presente de relação entre entidades e autarquias; as perspetivas de relacionamento futuro; os acordos tripartidos enquanto modalidade de apoio específica. Dada a heterogeneidade quer dos municípios quer das entidades artísticas e, por consequência, a grande variedade das ligações entre uns e outras, constata-se uma enorme dispersão de temas referidos e pontos de valorização ou crítica do trabalho autárquico.

Desde logo, a própria experiência de contacto com as autarquias é bastante diferenciada na amostra inquirida: quase metade (46\%) das entidades dizem não ter relação com autarquias locais; 33\% referem uma relação de apoio ou

\footnotetext{
${ }^{42}$ Q25. A administração local desempenha uma função crescentemente importante no campo das artes. Pode descrever como tem sido a relação da entidade com a administração local no quadro dos apoios às artes atribuídos pela DGArtes? A taxa de resposta é $71 \%$.

Q26. No futuro, que papel poderá ser desempenhado pela administração local no modelo de apoio às artes? A taxa de resposta é $69 \%$.

Q27. A articulação das entidades artísticas com a administração central e local é atualmente objeto de uma modalidade específica de apoio às artes já referida (acordos tripartidos). Caso a entidade tenha experiência de trabalho direta ou indireta com este tipo de apoio, por favor descreva-a, incluindo eventuais sugestões de alteração que julgue relevantes. A taxa de resposta é $46 \%$.
} 
mesmo parceria formal; um número residual refere explicitamente as autarquias como compradoras; as restantes referem algum tipo de ligação sem a caracterizar $^{43}$.

Não obstante a dispersão de posicionamentos, é possível identificar alguns tópicos centrais nesta matéria: relação entre autarquias e entidades artísticas; relação entre administração central e local; formalidades e aspetos processuais; circulação das produções artísticas.

\section{Relação entre autarquias e entidades artísticas}

Cruzando representações do funcionamento do poder local em geral e experiências particulares de contacto com as autarquias, observa-se uma perceção contrastante do processo político local: por um lado, valorização da proximidade e conhecimento do terreno pela administração autárquica; por outro, desconfiança face a riscos de falta de transparência e partidarização. Outro aspeto igualmente determinante na leitura do papel das autarquias é o défice de competências técnicas específicas no domínio das artes, por vezes associado à insuficiente delegação de competências e recursos por parte da administração central.

\section{Relação de proximidade}

Um denominador comum da valorização do trabalho das autarquias prende-se com a proximidade decorrente da escala de intervenção local, apontada como vantagem que pode desdobrar-se em múltiplas formas de atuação: suporte financeiro e outro (em particular, num quadro de ausência da administração central); conhecimento do território, agentes culturais e populações; articulação a nível local de políticas sectoriais e estabelecimento de parcerias; viabilização de projetos candidatos a fundos europeus.

66 A nossa realidade diz-nos que a administração local já teve um maior envolvimento no apoio às artes, afirmamos mesmo que se não fosse o papel das autarquias e a situação actual das artes seria bastante pior. A nossa estrutura já não existiria há muito tempo se não contássemos com o apoio do poder local.

[285 - teatro, teve apoio]

\footnotetext{
${ }^{43}$ Estas percentagens devem ser tomadas apenas como valores indicativos, uma vez que se trata de respostas a perguntas abertas.
} 
6 Um papel fundamental, pois são conhecedoras do território de ação e determinantes na consolidação das estruturas e no desenvolvimento de um programa articulado para a cidade e para a região.

[369 - artes plásticas, teve apoio]

66 É fundamental que a administração local assuma um papel central no apoio às artes, quer pelo conhecimento da realidade, quer pela proximidade com a população

[397- cruzamentos disciplinares, nunca concorreu]

66 As Autarquias têm um sentido prático e directo com as entidades e as suas populações que facilita o seu desenvolvimento, o seu progresso, a fidelização de públicos e o enraizamento das estruturas no meios locais. A experiência das Autarquias na educação poderia ser um modelo a seguir para cultura.. Uma reforma dessa natureza resolveria a miríade de problemas que se vive no campo das Artes do Espectáculo e clarificaria o panorama sombrio que nesta área se vive deste há muitos anos.

[287 - dança, teve apoio]

66 A relação com a Câmara Municipal [...] tem sido fundamental na concretização do [evento], ano após ano, pois tem cedido instalações, serviços e funcionários especializados, bem como importantes apoios financeiros. Tem desempenhado também uma função reguladora face às diversas atividades culturais que se desenrolam no concelho. E é frequentemente chamada a dar representatividade institucional à iniciativa, tornando-a mais abrangente e visível junto da população, contribuindo assim para que o [evento] se prestigie cada vez mais e o seu público se renove de ano para ano.

[143 - música, teve apoio]

66 Achamos que a administração local deve ter um peso maior no apoio às artes, embora não achemos que deve sustentar todo o apoio à criação/programação das estruturas. A relação de proximidade que deve ter com as estruturas locais pode também dar origem a outro tipo de funções, que podem passar pela estruturação de redes de colaboração, intercâmbio de práticas e pesquisa artística

[410 - teatro, teve apoio]

66 No nosso caso atual, o apoio da administração local tem sido bastante superior ao da dgArtes em todos os níveis: no apoio logístico, de comunicação, financeiro, de acompanhamento e avaliação e inclusive no que respeita ao diálogo 
onde se pensam em conjunto novos projetos para um futuro a médio e longo prazo.

[488 - teatro, teve apoio]

6 A administração local, nomeadamente algumas autarquias da região que têm co-financiado as actividades desta estrutura, representa um apoio anual de cerca de $15 \%$ do orçamento global da entidade. A mais valia da nossa relação com o poder local adveio de ter permitido entre 2009 e 2015 um acesso mais facilitado a fundos comunitários, através do estabelecimento de parcerias.

[485 - cruzamentos disciplinares, teve apoio]

\section{Dificuldades de relacionamento}

No sentido oposto, a perceção das atribuições e competências que cabem às autarquias é prejudicada por duas críticas vincadas: o défice de capacidade estratégica e técnica no que respeita à produção e programação cultural; o risco de ingerência ou mesmo instrumentalização político-partidária da atividade das entidades artísticas.

Embora a ressonância negativa destes fatores seja por vezes relativizada pelo reconhecimento da exiguidade de recursos humanos e financeiros das câmaras municipais ou, noutro sentido, pelo reconhecimento do excecional trabalho cultural de alguns municípios, trata-se de opiniões recorrentes - cuja validade não cabe aqui aferir - que têm um impacto importante na imagem da intervenção autárquica.

6 Não consideramos, no entanto, que se possa afirmar de forma cabal que "a administração local desempenha uma função crescentemente importante no campo das artes". Esta relevância está circunscrita a alguns municípios, deixando de fora a esmagadora maioria, que não observam princípios de relação ética, nuns casos, informada, noutros, com o sector das artes. Os dois factores que maioritariamente nos levam a concluir isto mesmo são a excessiva partidarização da administração local, cuja actividade não é suficientemente escrutinada e tem permitido o agravamento de redes de influência local e regional, e a gritante falta de competências na área da cultura na maioria das autarquias.

[376 - dança, teve apoio]

6 A administração local não tem capacidades técnicas e artísticas para aferir a qualidade de um projecto. Não necessariamente por incompetência, embora 
ela exista, mas sobretudo por falta de experiência. Nas zonas rurais não existem praticamente museus de artes plásticas, a programação é limitada ou inexistente. Como podem estas pessoas avaliar um projecto de artes plasticas?

[131 - artes plásticas, nunca concorreu]

6

De notar também as grandes dificuldades de articulação da administração local com os programadores e ou diretores dos espaços culturais. Na sua maioria as autarquias não têm funcionários competentes e especializados para tratarem dos assuntos e programação cultural local. A intervenção do poder local na área cultural é na generalidade demasiado protecionista o que invalida a visão programática de um diretor artístico ou o trabalho independente de um programador.

[345 - dança, teve apoio]

66 E dá-nos uma noção muito nítida de que a participação do município na vida cultural das entidades que nele desenvolvem a sua actividade é demasiado permeável aos interesses e responsabilidades políticas e ideológicas de cada executivo e, mais frequentemente do que desejado, à cultura pessoal e gosto individual dos seus presidentes. Arriscamo-nos a sugerir que isto é tão mais verdade quanto menor for o município.

[529 - teatro, teve apoio]

66 No entanto, somos da opinião que a administração local tem uma grande falta de técnicos especializados nas áreas artísticas e criativas e tem uma visão muito economicista desta área, sem no entanto entender que esta é fundamental para o desenvolvimento das regiões, mas que requer muito tempo e investimento, para além das festas e feiras com grande visibilidade. É urgente haver formação específica para os executivos e técnicos locais das áreas culturais e artísticas.

[437 - teatro, teve apoio]

6 Quanto às instituições camarárias que acolhem a digressão, as relações pecam também pela parca celeridade em dar resposta aos compromissos acertados (nomeadamente pelo atraso em pagamentos). Por outro lado, a dificuldade dos processos camarários e as restrições financeiras que tais processos morosos e dispendiosos exigem (contratos de abertura - ajustes diretos), dificultam em muito o lado prático dos processos contratuais com as câmaras e os pagamentos daí decorrentes.

[345 - dança, teve apoio] 


\section{Relação entre administração central e local}

Um outro aspeto nuclear na reflexão sobre o papel das autarquias é, como seria de esperar, a definição de atribuições e esferas de atuação entre o poder central e local, seja no sentido de articulação mais próxima, seja pelo contrário no sentido de demarcação de funções. Para além dos posicionamentos mais polarizados - que advogam ora a exclusão ora a maior integração possível da administração local no sistema de apoio às artes -, a reflexão das entidades sobre este tema traduz-se num extenso leque de hipóteses e fatores críticos da articulação política a nível central e local.

No conjunto seguinte de citações procura-se tipificar as principais linhas de debate: separação de funções entre níveis administrativos; complementaridade de funções entre níveis administrativos; articulação coordenada pela tutela da cultura; desresponsabilização da administração central; promoção da iniciativa municipal.

\section{Separação de funções entre níveis administrativos}

66 o poder local tem a liberdade de desenvolver os projectos que muito bem entenda, com os recursos que entenda, devendo por isso responder perante os seus eleitores. Questão diferente e que importa não confundir coma anterior, é qual o papel do Estado. Em meu entender o Estado pode e deve actuar de forma mais criteriosa, intencional, muscular, no apoio à criação contemporânea, difusão desta, sua descodificação, etc.

[299 - arquitetura, concorreu mas nunca teve apoio]

6 Não pensamos que os municípios devam ter um papel relevante nesse domínio pelo facto de estarem sujeitos a agendas e interesses demasiado locais e muitas vezes a inovação é preterida em favor do facilitismo artístico

[903 - cruzamentos disciplinares, teve apoio]

66 Na nossa opinião a interacção com uma administração local pode criar entropia; Muitas vezes as finalidades das administrações locais são muito diferentes dos objectivos procurados por uma entidade apoiada pela dgartes para fins artísticos. Achamos que aspectos políticos pontuais são muito evidentes no seio das administrações locais. Esperamos portanto que não haja muito avanço neste sentido. As entidades devem ser financiadas unicamente perante o projecto artístico que entendem desenvolver.

[296 - música, teve apoio] 
6 A DGArtes tem um papel absolutamente fulcral no apoio às artes. As autarquias devem ter outro tipo de intervenção. Não se devem confundir ambos nem - PIOR AINDA - fazer depender um do outro!

[85 - dança, teve apoio]

66 Não nos parece que a administração local tenha uma função importante, por não ter meios nem estratégia para isso.

[265 - dança, teve apoio]

6 Acho que a administração local deve ser mais um foco de apoio e deve ter as suas prioridades culturais independentes da administração central. Devem estar em diálogo para esclarecimento de dúvidas mas não devem trabalhar juntas com risco de despontenciar apoios. A administração local poderia centrarse mais no apoio estrutural dos projetos e no incentivo aos jovens artistas.

[460 - teatro, concorreu mas nunca teve apoio]

66 A entidade entende que os papéis da administração local e da administração central (DGArtes) no apoio às artes não devem ser confundidos. À DGArtes compete valorizar a criação artística. Às administrações locais compete valorizar/apoiar a sua localidade, segundo os seus próprios objetivos. Por vezes os objetivos das administrações locais e central coincidem, mas sempre de forma casual e passageira. A validação artística de um projeto não deverá nunca passar pela administração local.

[429 - teatro, teve apoio]

\section{Complementaridade de funções entre níveis administrativos}

66 Talvez o melhor papel que poderia ter seria o de promover uma verdadeira articulação com outras administrações locais para que exista, efectivamente, uma programação em rede a nível nacional.

[28 - música, teve apoio]

66 O Ministério da Cultura devia fazer protocolos directos com as comunidades inter-municipais e autarquias no sentido da responsabilização directa pela política cultural.

[7 9- música, teve apoio]

66 Fazendo a DGartes, nomeadamente através das delegações regionais o papel de plataforma intermediária entre artistas, espaços e instituições formativas, 
à administração local compete a parte de aplicar as suas infraestruturas e espaços artísticos no sentido de desenvolver a programação cultural com projetos a concurso.

[65 - música, nunca concorreu]

66 Portanto, a questão da responsabilização dos municípios deve, a nosso ver, cingir-se a áreas, como sejam: a da criação/manutenção/implementação logística; o incremento e acompanhamento de certo tipo de relações institucionais locais/regionais (por exemplo, por via da instância Associação de Municípios) com concertado e declarado interesse cultural; ou em contributos para a cidadania afectos à dinâmica das cidades. Em conformidade, defendemos que a instância de financiamento à Criação ( e nalguns casos particulares também à Programação) essas(s) deve $(\mathrm{m})$ ser (em) assegurada(s) directamente pelo Estado por via da respectiva instância da tutela. E defendemos assim, porque a diversidade, em geral (estruturas, municípios), é muito significativa.

[427 - teatro, teve apoio]

6 A tutela poderia/deveria criar mecanismos que levassem as autarquias onde os projetos "residem" a apoiar essas mesmas estruturas. Estas estruturas não deveriam assim estar sujeitas a concursos, deveriam ser financiadas desde que monitorizadas de perto, à imagem do que acontece com as orquestras regionais.

[277 - música, teve apoio]

6 A nós, que desenvolvemos a nossa actividade fora de Lisboa, parece-nos essencial pensar num modelo de financiamento que permita unir os esforços das autarquias ao do Estado.

[528 - teatro, concorreu mas nunca teve apoio]

6 Na nossa opinião, a dgArtes deveria manter um diálogo permanente com a administração local que acolhe no seu território projetos artísticos apoiados pela dgArtes e mesmo, outros projetos, que não sendo ainda apoiados, tenham forte probabilidade de virem a beneficiar de apoio no futuro. Acreditamos que este diálogo entre dgArtes e administração local poderá ser bastante elucidativa do efetivo apoio e compromisso que as diferentes câmaras municipais e outros orgãos locais desenvolvem de facto com os projetos artísticos da região e assim, perceber de que maneira poderá ser desenvolvido um maior equilíbrio nos apoios por ambas as partes (admin. local e dgArtes), garantindo uma coresponsabilização no apoio às artes entre administração local e central.

[488 - teatro, teve apoio] 
6 A Direcção-Geral das Artes, em conjunto com os diferentes agentes artísticos, poderia ser um interlocutor mais presente e mais profícuo com as autarquias dos territórios dos referidos agentes artísticos. Sensibilizando os autarcas e as autarquias para o investimento suplementar, a acrescentar ao da DGArtes, com claros benefícios para os territórios em questão.

[414 - teatro, teve apoio]

\section{Articulação coordenada pela tutela da cultura}

66 É fundamental enquadrar e coordenar a política cultural nacional com as políticas culturais regionais. A administração central deverá ter um papel de coordenação e até regulador das políticas culturais locais que muitas vezes estão até em oposição.

[244 - cruzamentos disciplinares, teve apoio]

66 Parceiro determinante no sucesso dos projetos, garantido a autonomia artística, administrativa e de gestão, mas preservando a tutela reguladora da DGArtes/Ministério da Cultura.

[413 - cruzamentos disciplinares, teve apoio

66 Em síntese: consideramos que não deve ser alienado o vínculo à instância central da tutela como forma de garantir independência e equidade a diversos níveis. Declinar para a administração local certo tipo de decisões, nalguns casos, pode corresponder a uma menorização da importância da Criação (e também da Programação) artística no desenvolvimento geral do país no contexto da Europa e do Mundo.

[427 - teatro, teve apoio]

66 Pensamos que as linhas estratégicas de política cultural devem ser estabelecidas pelo Estado Central. Nesse sentido, embora as autarquias devam ter um papel importante no apoio às estruturas artísticas e devam ser aliadas da DGArtes na implementação das politicas culturais ao nível do território, os financiamentos e avaliações devem ser da responsabilidade do governo, sob pena de a sobrevivência das estruturas estar dependente de inclinações partidárias, sem visão estratégica nacional sobre o trabalho desenvolvido.

[377 - teatro, teve apoio] 


\section{Desresponsabilização da administração central}

G6 Esta é uma questão larga demais para poder ser respondida aqui. O que este papel [da Administração Local] não pode ser é uma oportunidade do estado (central) se demitir do seu papel no modelo de apoio.

[419 - música, teve apoio]

6 A administração local não pode substituir as obrigação da administração central no que concerne ao apoio à artes, pois as autarquias não só não têm capacidade financeira para servir de suporte substancial aos agentes culturais no terreno, como os seus interesses (cultura) não são compatíveis com a produção artística contemporânea e independente (arte).

[485 - cruzamentos disciplinares, teve apoio]

66 O crescente papel da administração local no apoio às artes está intimamente ligado aos constantes cortes das verbas dos OE para a Cultura. $O$ aumento do apoio da administração local não tem servido propriamente para aumentar o número de entidades, projectos, festivais, entidades, etc, apoiados, tem servido, isso sim, para minorar o desinvestimento da administração central.

[242 - teatro, nunca concorreu]

\section{Promoção da iniciativa municipal}

6 [As autarquias] devem absorver parte da DRC, como da EDUCAÇÃO.

[50 - artes plásticas, nunca concorreu]

66 A Administração local pode ter um papel muito importante aravés das Comunidades Intermunicipais.

[320 - música, nunca concorreu]

66 autarquias com grande recetividade na celebração de contratos programa concretos poderiam ser incentivadas a concretizá-los de forma continuada, se existissem mecanismos de reconhecimento efetivo dessa sua estratégica.

[260 - cruzamentos disciplinares, teve apoio]

6 a articulação entre a Administração Central e Local no quadro do apoio às artes passa necessariamente pelo reconhecimento do importante papel desempe- 
nhado pelas autarquias no garante do acesso à cultura e às artes, especialmente fora dos grandes centros. Esse reconhecimento deve ser acompanhado por um modelo de financiamento que abranja projetos culturais de iniciativa municipal e/ou nos quais as autarquias participem, garantindo assim a sustentabilidade, a continuidade e o crescimento destes projetos.

[476 - cruzamentos disciplinares, teve apoio]

6

Deve se manter e ser reforçado. É um importante apoio às entidades que não têm apoios do Ministério da Cultura.

[465 - fotografia, teve apoio]

66

Outra situação a valorizar muito na revisão do modelo de apoio às artes: as Autarquias devem ter um papel central, porque conhecem as entidades candidatas no terreno.

[106 - música, teve apoio]

\section{Formalidades e aspetos processuais}

No plano processual da articulação entre administração central e local - independentemente dessa articulação ser positiva ou negativamente valorada -, há um conjunto de dispositivos mencionados com frequência, embora não sejam consensuais: participação de representantes autárquicos nos júris concursais e nas comissões de avaliação; definição de quotas territoriais na aprovação de projetos apoiados; aplicação de critérios de majoração com referência territorial. Note-se também que a adoção de procedimentos formais do tipo concurso é uma reivindicação habitual a respeito da atribuição de apoios financeiros a nível local.

66 A administração local deveria fazer parte das Comissões de Apreciação das Candidaturas. Pensa-se que desta forma se assegure uma distribuição mais equitativa dos financiamentos para a cultura. Acreditamos que o facto dos Municípios emitirem "cartas de conforto" aos projetos que são candidatados não revela de todo o seu envolvimento no desenvolvimento cultural local.

[269 - artes plásticas, teve apoio]

6 Creio que as Câmaras municipais poderiam ter um papel na escolha dos projectos (uma espécie de quota) o que à partida também seria uma forma de garantir uma maior participação financeira e envolvimento dos municípios na 
cultura. Uma espécie de primeiro passo para uma verdadeira descentralização das artes. Outra forma poderia a abertura de concursos por parte dos próprios município, organizados nos mesmos moldes dos concursos da DGArtes mas para projectos à partida vocacionados e pensados para territórios específicos.

[436 - música, teve apoio]

6 Gostaríamos que o processo de apoio às artes pelo poder local fosse concursal, o que daria mais transparência à atribuição desses apoios. As estruturas não podem estar reféns do poder político para a distribuição de apoios.

[361 - cruzamentos disciplinares, teve apoio]

66 A administração local poderá chegar a áreas e entidades que a DGARTES não chega, sendo que deveriam existir procedimentos de candidatura semelhantes e transparentes quer na DGARTES, quer na administração local. Há muitas câmaras que atribuem apoios à cultura sem critérios claros e com pouca seriedade. Uma articulação directa entre a DGARTES e as câmaras poderia ser uma solução.

[412 - música, concorreu mas nunca teve apoio]

6 Ser a administração local a ter um ponto crucial na avaliação do trabalho que vem a ser desenvolvido pela entidade.

[168 - música, teve apoio]

6 o poder local da região de origem no projeto participar como elemento nos júris de avaliação dos projetos

[98 - dança, teve apoio]

66 Outra questão a ter em conta é na majoração dada aos apoios das instituições locais. Como é sabido, alguma destas estão falidas e vão demorar anos ate poderem comparticipar monetariamente as estruturas locais, o que colocam alguns de nós logo em posição de desvantagem, em relação aqueles que estão sediados em locais onde estas instituições podem apoia-los monetariamente.

[52 - música, nunca concorreu]

\section{Circulação das produções artísticas}

6 De facto, poderá dizer-se que houve um enorme retrocesso, por parte da administração local, no que diz respeito ao seu envolvimento e aquisição de pro- 
dutos artísticos. Cada vez mais voltadas para o retorno financeiro que estruturas e equipas artísticas que as TVs publicitam, obliteram os que a ela não têm acesso.

$$
\text { [461 - teatro, teve apoio] }
$$

66 Em relação às outras dezenas de autarquias com as quais nos relacionamos, nomeadamente a propósito da circulação nacional dos nossos espectáculos, encontramos enormes disparidades e assimetrias na forma como a actividade cultural profissional é encarada.

[498 - teatro, teve apoio]

6 A DGartes deveria criar uma caderneta de espectáculos (após a aprovação das candidaturas, mas abertas a todos os que queiram concorrer) com as condições (logísticas, técnicas e valores), distribuir essa caderneta com algumas verbas junto dos municípios para que estes comprem alguns espectáculos, promovendo a circulação e atribuindo aos municípios a responsabilidade de programarem para a sua comunidade.

[286 - teatro, teve apoio]

66 A companhia reconhece que tem hoje uma responsabilidade social no território local. Com a administração local desenvolve anualmente um programa de intervenção no território nomeadamente com as populações geograficamente mais isoladas e com as escolas por exemplo.

[281 - teatro, teve apoio]

64 A relação é de grande proximidade não só no suporte financeiro e logístico como também ao nível da programação. A rede de colaboradores locais das autarquias reúnem periodicamente com a equipa [...] reflectindo sobre as acções desenvolvidas e as que se pretendem desenvolver. Também ao nível do protejo educativo e comunitário esta relação é de grande proximidade e partiIha. Procuram, em conjunto, as melhores estratégias de responder ao território.

[522 - teatro, teve apoio]

\section{Acordos tripartidos}

As respostas à pergunta sobre os acordos tripartidos circunscrevem-se às entidades com experiência, direta ou indireta, desta modalidade de apoio; a taxa de resposta é das menores do inquérito e, dentro das entidades que respondem, apenas uma minoria se pronuncia favorável ou desfavoravelmente sobre 
esta medida (embora a sua avaliação não fosse expressamente solicitada no enunciado).

\section{Apreciações}

Entre os fatores para um balanço positivo da participação em acordos tripartidos podem destacar-se: consolidação de relações de confiança entre autarquias e entidades artísticas; planeamento a prazo; rentabilização do investimento financeiro; execução de políticas territoriais integradas.

66 Este apoio tripartido veio reforçar o trabalho da estrutura a nível local gerando mais colaboração, cooperaç̃o e confiança embora com eleições todo o trabaIho pode ser posto em causa com mudanças de executivas.

[440 - dança, teve apoio]

6 E' muito importante a modalidade dos acordos tripartidos. Permite uma notável redução de custos e uma melhoria dos beneficios para a população. E' um trabalho em rede que o novo modelo de apoio às artes deveria incentivar mais. No nosso caso esta modalidade permitiu que a mesma produção musical foi circulando em 3 autarquias distintas nas mesmas datas, poupando nas viagens, estadias....

[106 - música, teve apoio]

66 A [entidade] tem sido largamente beneficiada com a modalidade 'acordos tripartidos'. O apoio da DGArtes tem sido fundamental, uma vez que a antecipação temporal de cada período (quadrienal) dá uma segurança incontestável à programação, tornando-se assim possível antecipar o desejável desenho programático coerente, ano a ano .

[143 - música, teve apoio]

66 A experiência destes últimos 4 anos com um consórcio formado por múltiplas entidades tem sido, na perspectiva da nossa entidade, gratificante pelo facto de ter permitido (nestes tempos de "crise") a consolidação da nossa estrutura que tem viabilizado a execução de outros projetos com outras fontes de financiamento. Tem sido possível aproximar mais pessoas a desempenhar papéis de direção nos seus projetos num "ninho" colectivo, trazendo mais diversidade de ação, permitindo mais trabalho remunerado e condições de fixação no contexto rural, contribuindo para uma contra-tendência migratória apetrechando a Cidade de mais recursos humanos altamente especializados nas áreas mais 
diversas. Por outro lado o trabalho articulado com os coparceiros tem enriquecido a forma de pensar a programação através da articulação de agendas e ciclos programáticos, bem como a partilha de recursos materiais e humanos.

[154 - outra área, teve apoio]

66 A modalidade tripartidos parece-nos, pela experiência, a melhor e a mais eficaz. Obriga os parceiros a uma reflexão mais profunda e alargada sobre os objectivos que a Cidade se propõe alcançar num período mais dilatado de tempo, em áreas que podem não ser apenas culturais e artísticas, mas transversais, como a coesão e exclusão sociais, a educação e a economia, a diversidade cultural e a diferença, o tecido empresarial e as universidades. Essa atenção global à Cidade, às suas debilidades e mais - valias, ajudam a organizar a Criação Artística e a Formação de Públicos, as estratégias de parceria e rede, tornando mais fácil e coerente cada projecto. 0 modelo de acordo tripartido, se olhado como seriedade pode ser um instrumento valioso para o crescimento sustentado da Cidade.

[229 - teatro, teve apoio]

No polo oposto, fatores críticos ou negativos: incapacidade de responsabilização nos casos de incumprimento das autarquias; falta de transparência; procedimentos burocráticos excessivos; limitação de candidatura única por município; falta de garantia da comparticipação financeira das autarquias.

6

Mas considerando a experiência sobre o modelo em si: os tripartidos foram uma tentativa de responsabilização das autarquias por parte da dgartes que, na prática, não resultou - porque a DGArtes não tem poder para fazer com que as autarquias condicionem agendas financeiras ou, tão pouco, mantenham compromissos inicialmente previstos.

[311 - cruzamentos disciplinares, teve apoio]

G6 Apesar dos acordos tripartidos terem representado uma corajosa decisão de envolver as autarquias com os agentes, somos bastante críticos em relação a este modelo. Em primeiro lugar [...], não concordamos com o facto da candidatura ser feita através de um júri interno da DGArtes, pois o processo falha na transparência. Em segundo lugar gostaríamos de chamar a atenção para o facto da articulação entre entidades não se fazer por decreto, mas sim por empatia e cumplicidade profissional. Seria preferível que uma estrutura aberta, solidária e comunicante com os seus pares, fosse pontuada generosamente num concurso directo. $\mathrm{O}$ facto de estruturas mais frágeis estarem incluídas num financiamento automático, introduz um factor de distorção na avaliação $[\ldots]$.

[418 - cruzamentos disciplinares, teve apoio] 
6 O modelo de acordo (como figura jurídica) não defendeu a entidade da alteração unívoca das condições iniciais propostas pelos municípios, nem dos atrasos no cumprimento dos seus compromissos. Igualmente grave, é o facto de não ficar claro quem é o beneficiário do apoio, pois os municípios exercem pressão para tirar dividendos políticos e financeiros do programa que o acordo viabiliza. Por outro lado, observando outras experiências similares, percebe-se que estes acordos beneficiam muitas vezes territórios e municípios que já estavam dotados de meios para o desenvolvimento cultural - tratando-se por isso de um reforço e não da resolução de uma lacuna. Em suma, estes acordos não responsabilizaram os municípios, mas as estruturas, e, se beneficiaram parcialmente as estruturas, fizeram delas pontas de lança de mudanças que não se pode exigir serem da sua responsabilidade.

[376 - dança, teve apoio]

66 Até ao presente temos sentido como muito negativa a regra que estipula que cada Município apenas possa desenvolver um acordo tripartido, particularmente em câmaras de grande dimensão, uma vez que nem sempre é possível juntar num só acordo as diferentes instituições que poderiam beneficiar deste tipo de apoio.

[363 - dança, teve apoio]

6 É importante que a contribuição do município seja financeira e não maioritariamente em serviços. O mesmo valor atribuído pela dgartes deverá ser o mesmo atribuído pelos municípios. Existe um comportamento viciado e por vezes incorrecto como os municípios inventarem apoios em serviços para não cumprirem com as suas responsabilidades com os projectos. Assim, o volume e patamar financeiro a que as estruturas concorrem seria mais adequado com a realidade do próprio município e acabaríamos de vez com a originalidade de como saber inventar serviços para aumentar orçamentos.

[514 - cruzamentos disciplinares, teve apoio]

66 Constata-se mesmo que o atual modelo de acordos tripartidos deu aos municípios um ascendente sobre meios que são, teoricamente, destinados ao tecido independente, criando-se mais um filtro para as estruturas no acesso ao financiamento do Estado para o apoio às artes, num sistema estrangulado financeiramente. A esperada responsabilização das autarquias através destes acordos só se verificou efetivamente nos casos em que as autarquias já tinham boas práticas no apoio às artes ou já existiam acordos sólidos entre setor público e independente.

[335 - dança, concorreu mas nunca teve apoio] 


\section{Propostas}

66 A entidade encontra-se ao abrigo de um acordo tripartido, juntamente com duas câmaras municipais e uma outra entidade de criação. Relativamente à relação com a autarquia com a qual já trabalha há 16 anos, o facto de terem desenvolvido no último biénio um acordo tripartido, na prática, não significou qualquer tipo de alteração num bom relacionamento que já prevalecia. A entidade entende que os acordos tripartidos não fazem sentido no panorama nacional. $\mathrm{O}$ apoio autárquico deve ser um fator de majoração e não dar azo a uma modalidade específica de apoio.

[429 - teatro, teve apoio]

66 Ora, os "Acordos Tripartidos" vieram a demonstrar-se pouco distintos das candidaturas de estruturas pluridisciplinares dentro do quadro bienal ou quadrienal que tinham um apoio e reconhecimento substantivo da Autarquia. Importa que o novo modelo de apoio às artes defina, com maior clareza os conceitos e a filosofia que possa presidir em manter esta modalidade de apoio. Para isso, importa desde logo, especificar o que a distingue dos apoios diretos, uma vez que estes têm igualmente como fator valorativo o apoio concedido pela Autarquia/sede da estrutura.

[260 - cruzamentos disciplinares, teve apoio]

6 No que diz respeito à correção de desigualdades territoriais, devem ser valorizados projectos que possam trazer grande qualidade à oferta local/ regional. Neste ponto remetemos para a ideia de substituir os acordos tripartidos por duas medidas que nos parecem mais adequadas. 1. Uma que valorize o trabaIho que muitas estruturas já realizam e que muitas vezes não tem como parceiro principal os municípios, dando-lhes outra margem de financiamento parcerias estratégicas que os candidatos podem especificar de acordo com a sua área de especialidade. Em todas as regiões existem estruturas que já estão a fazer este trabalho, mas ficam fora dos apoios diretos ou indiretos (tripartidos). 2. Um concurso específico para zonas carenciadas, devidamente sinalizadas, com projectos tailor made pelas estruturas independentes, de acordo com as necessidades sinalizadas e recursos postos à disposição pelos municípios. Este concurso deve garantir financiamento, dos municípios e da tutela, e condições estruturais, privilegiando uma estreita relação com os novos territórios a qualificar e, quando possível, a fixação de equipas no local ou a contratação de equipas nestes locais.

[376 - dança, teve apoio]

6 Entende-se como condições necessárias para aceder a apoio indireto - acordo tripartido: 1 . O projeto ser liderado por uma estrutura independente; 2 . Cada 
Autarquia poder ser parceira de mais do que um projeto, se o considerar relevante; 3 . Os contratos serem efetivos e não intenções de compromisso, como acontece com os atuais acordos; 4. Garantia, através da lei dos compromissos, pelos anos de vigência do contrato; 5 . Apoio financeiro obrigatório, através de uma implicação percentual da Autarquia no orçamento global; 6 . A Autarquia demonstrar atividade cultural extra o acordo tripartido; 7. A separação clara e inequívoca entre poder político e programação; 8 . Ambas as partes manterem as condições do acordo por todo o período estabelecido, nomeadamente: - A continuidade do acordo; - As responsabilidades assumidas; - $O$ valor do investimento; - A estrutura programática do projeto; - A adequação entre os recursos postos à disposição da estrutura pela autarquia e a natureza do projeto.

[335 - dança, concorreu mas nunca teve apoio]

\section{Redes de programação}

O questionário inclui uma pergunta genérica sobre a eventual articulação entre o sistema de apoio às artes e redes de programação ${ }^{44}$. As respostas referem-se a diferentes aceções da expressão, como sejam: plataformas formais ou informais de circulação de produções artísticas; protocolos de programação entre agentes e entidades; redes de equipamentos e infraestruturas. Para efeitos de análise, consideram-se três temas principais: representações da noção de rede; processos de funcionamento; mercado.

As redes de programação são vistas, de forma geral, como elemento fundamental da política pública para o sector. Talvez por isso o leque de posicionamentos é muito disperso, desde a total integração entre modelo de apoios e redes de programação (por exemplo: impondo uma quota de produções apoiadas na programação dos equipamentos integrantes de redes públicas ou com apoio público e/ou obrigando à circulação de projetos de criação apoiados através de concurso por equipamentos públicos distribuídos pelo território) até à total separação da gestão dos dois instrumentos de política pública (cabendo exclusivamente à DGArtes a gestão do sistema de apoios). Algumas entidades defendem a este propósito a recuperação de programas de circulação promovidos no passado pela DGArtes (por exemplo, o Programa Território Artes).

É apontada em geral a necessidade de maior financiamento e distinto do modelo de apoio, bem como, do ponto de vista formal, a implementação de

\footnotetext{
${ }^{44}$ Q28. Em que medida o modelo de apoio às artes deve contemplar a articulação com redes de programação? A taxa de resposta é $70 \%$.
} 
mecanismos que assegurem transparência e diversidade de produções programadas.

\section{Representações da noção de rede}

\section{Apreciação}

As redes de programação são vistas usualmente como um possível canal de difusão da produção artística, prevendo-se a articulação entre as duas vertentes. Porém, é também visível alguma desconfiança com que as redes são olhadas por uma parcela dos criadores - patente quer na sua desvalorização, quer na sua subordinação às políticas públicas num plano distinto do sistema de apoio às artes.

6 Um projeto só tem a ganhar se integrar uma rede ou várias redes de programação. É uma necessidade urgente dinamizar essas redes de programação.

[182 - música, concorreu mas nunca teve apoio]

6 A articulação com redes de programação pode ser um factor mais, mas ao qual não se deve atribuir demasiada importância - para além do facto de existirem muitas redes que efectivamente funcionam ainda que careçam de "formalização" (o que não nos parece ser um problema), existem obviamente projectos que, pelas suas naturezas específicas não são "matéria" para redes ou até para circulação, não devendo por isso ser necessariamente penalizados.

[297 - música, teve apoio]

64 Não percebemos o conceito de redes de programação: programação é uma atividade específica sob a tutela de um diretor de programação que faz escoIhas artísticas : um diretor artístico. A DgArtes como já referimos deve ter um papel no cofinanciamento à circulação de projetos apoiados e à proposta de integração na programação de equipamentos que tenham uma direção artística. A DgArtes pode e deveria ser a principal promotora de redes de circulação nacional e até internacional de projetos apoiados.

[480 - música, teve apoio]

66 As redes de programação regem-se pelas leis de mercado e pelas apreciações artísticas particulares dos programadores, na sua grande maioria afetos a autarquias que se regem segundo objetivos próprios. O panorama nacional é extremamente heterogéneo e propenso a clientelas e politizações. Os apoios do 
Ministério da Cultura/DGArtes devem manter-se totalmente à margem das redes de programação.

[429 - teatro, teve apoio]

66 Na nossa opinião, que é partilhada por muitas entidades de criação e algumas de programação, as redes de programação têm tido um impacto muito negativo no setor e na circulação de espetáculos. Fomentam a segregação de uma grande maioria de espetáculos que não "conseguem" circular nas ditas redes e por outro lado, elegem um número mínimo de espetáculos que conseguem circular por um número significativos do espaço, monopolizando assim a circulação de espetáculos. As redes reduzem a independência de muita programação descentralizada, uma vez que muitos equipamentos fora dos grandes centros urbanos, acabam por se transformar em "programações satétile" dos "grandes programadores" dessa rede (que são os dos grandes centros ou os que têm mais dinheiro para programar).

[502 - teatro, concorreu mas nunca teve apoio]

64 Neste modelo em si não vemos razão para contemplar esta articulação. Ela é feita justamente entre a entidade candidata/apoiada e estas redes (nacionais e internacionais) existentes e identificada na descrição das parcerias. Caso a DGArtes venha a contemplar o apoio à programação da rede cine-teatros e equipamentos (quer estes funcionem ou não em rede), pode ser pensada a relação que estas têm com as entidades alvo de apoio (nas várias tipologias) por parte da DGArtes.

[459 - teatro, teve apoio]

6 As redes de programação e o denominado "funcionamento em rede dos agentes culturais" não devem ser contemplados em sede de avaliação de candidaturas. Só assim se pode garantir que as redes patrocinadas pelas estruturas têm outros objetivos que não apenas, como acontece em alguns casos, valorizar as candidaturas das estruturas-membro. As redes de programação devem ser públicas e não uma estratégia privada ou independente orientada para conseguir financiamento por parte dos agentes culturais. É ao Estado que compete e é o Estado que detém os instrumentos mais eficazes para promover, financiar, fiscalizar e renovar redes de programação de âmbito nacional. Tudo o mais, e considerem-se as "redes" atualmente existentes, resultam em pouco mais do que conglomerados de interesses de agentes culturais.

[506 - teatro, teve apoio]

6 É vital que se faça um esforços para harmonizar o volume do que se cria com a capacidade de difundir, pelo que as duas questões não podem ser pensadas de forma isolada. Mas em caso algum se deverá colocar em causa a liberdade para criar/produzir (para decidir o que criar/produzir) em função das decisões de 
programar/não programar tomadas por terceiros. $\mathrm{O}$ apoio direto aos criadores deve continuar a ser o eixo do modelo português de apoio às artes.

[209 - teatro, teve apoio]

\section{Fechamento}

Pelo menos para parte dos criadores, um dos principais receios expressos a respeito do papel desempenhado pelas redes de programação é o de poderem representar não uma plataforma de circulação, mas, pelo contrário, um filtro adicional no acesso ao mercado.

6 Há no entanto redes de programação muito fortes. Parece-nos perigoso que estas redes que controlam uma grande parte do território e que estão ligadas ás autarquias que já investem na cultura, venham a ter um papel ainda mais predominante e de maior controlo e poder. Como são redes com muitos elementos, conseguem fazer crescer um determinado projeto ou fazer desaparecer outro.

[479 - dança, teve apoio]

6 Não temos pudor em afirmar que, de um modo geral, os agentes de programação têm-se afirmado como "polícias do gosto", impondo o seu próprio paradigma ao público; isto é: aplicam, em exclusivo, o seu gosto pessoal aos critérios da sua programação pública. Admitimos, sem reserva intelectual, que haja casos em que tal se justifique; mas, de um modo geral, este processo é empolgado e até, por vezes, elevado a níveis caricatos, havendo programadores que se alcandoram ao apodo de "directores artísticos" - sem que nunca tenham criado, dirigido ou participado na criação de qualquer obra artística.

[427 - teatro, teve apoio]

66 O modelo de apoio às artes deve não só premiar quem se integra dentro das redes, mas acima de tudo, quem está a criar novas redes, apelando uma vez mais à diversidade artística. As redes de programação são importantes, no entanto são perigosas, pois alimentam-se entre si. Ou seja, criam um circuito fechado quer ao nível dos projetos quer ao nível financeiro. Teoricamente a ideia de rede é muito interessante, mas a experiência tem demonstrado que as redes acabam por tem muito poder (e dinheiro) o que adultera o conceito inicial.

[286 - teatro, teve apoio] 


\section{Criadores e programadores}

O debate sobre as redes de programação faz sobressair com frequência um antagonismo - ou até alguma conflitualidade - entre as figuras de criador e programador. Este antagonismo, por vezes particularizado, remete para uma tensão latente - nem sempre explícita - entre as esferas da produção e da circulação.

6 O problema de fundo é a criação contemporânea. Meios para a criação em primeiro lugar. A difusão só surge em segundo lugar. Pode o Estado querer reforçar a circulação no território de exposições, concertos, espectáculos, etc, então que desenvolva um programa neste sentido, dote o mesmo de orçamento próprio, proponha-o aos agentes locais. O Estado e os agentes locais que tratem do assunto, que constituam as ditas redes; fazendo-o, o Estado que cative espaço para a circulação da criação contemporânea, em particular a criação por si apoiada. Mas que não se exija dos criadores que se façam portadores deste tipo de objectivos.

[299 - arquitetura, concorreu mas nunca teve apoio]

66 Apenas na medida em que as redes de programação devem estar ao serviço dos artistas e da criação artística e não o seu contrário. Os programadores culturais já têm um grande poder sobre os artistas: em grande medida e já patente na atribuição de apoios actual, são os programadores que definem quem tem visibilidade ou naõ, quem pode ser apresentado e quem não pode ser apresentado ao público.

[174 - cruzamentos disciplinares, nunca concorreu]

66 Têm sido os artistas e estruturas de criação que propõe a programação, ao colocarem determinado projeto à disposição dos programadores. Parece-nos perigoso atribuir uma excessiva valorização do programador face ao criador. 0 criador será sempre a origem de um projeto, pretendendo-se manter a tónica na logica da oferta e não da procura. Pretende-se que a programação exista como consequência da criação e não o contrário.

[479 - dança, teve apoio] 


\section{Processos de funcionamento}

\section{Enquadramento}

Uma das preocupações mais salientes é a necessidade de regulação, que pode assumir diferentes formas, como por exemplo no apoio a plataformas de divulgação e contacto ou na implementação de mecanismos de avaliação.

66 Parece evidente que se deveriam criar condições que favoreçam o relacionamento próximo entre entidades apoiadas, a partilha de programação ou actividades de criação que alimentem entidades de programação. Mas será errado e redutor construir um modelo que force essa relação como necessária ou que Ihe atribua um peso excessivo na avaliação das actividades.

[419 - música, teve apoio]

66 Seria bastante importante quer para os agentes culturais da área da programação quer para os artistas. Mas o apoio financeiro como único estimulo não basta. É fundamental que as entidades públicas apoiem os agentes culturais (seja qual for a sua dimensão) no processo de divulgação e integração nessa redes.

[232 - música, teve apoio]

64 À semelhança do que pensamos em relação às autarquias, as redes de programação devem ter um papel importante no apoio às estruturas artísticas e devam ser aliadas da DGArtes na implementação das politicas culturais, mas os financiamentos e avaliações devem ser da responsabilidade do governo, sob pena de a sobrevivência das estruturas estar dependente das inclinações estéticas dos programadores e de avaliações parciais do trabalho desenvolvido.

[377 - teatro, teve apoio]

66 O modelo de apoio às artes deve contemplar a articulação com redes de programação fora de uma lógica de mercado, nomeadamente organizando encontros bienais entre as entidades (singulares ou colectivas) e as referidas redes para divulgação, discussão e partilha de conteúdos. Entendemos que o apoio focado no financiamento de entidades para articulação com redes de programação resulta numa sobreposição de meios.

[327 - outra área, teve apoio] 


\section{Aspetos formais}

Tendo por objetivo regular o funcionamento das redes de programação, são sugeridos múltiplos dispositivos formais, focando aspetos diferenciados, incluindo o estatuto (por exemplo, instituindo um estatuto jurídico obrigatório ou a regulamentação da atividade) e funcionamento (como a contratualização de apoios públicos, atribuídos através de concursos e definição de metas quanto a produções programadas, por exemplo).

6 Deveria haver outro concurso ou forma de articulação com redes de programação, não se deve condicionar a criação com o facto de ter ou não articulação com redes de programação.

[257 - dança, teve apoio]

66 Para nós que dependemos da circulação para fazer o nosso trabalho, as redes de programação são fundamentais! Deveria existir um maior investimento. As redes de programação permitem-nos chegar aos programadores de forma estruturada, organizar calendário de apresentações bem como organizar financiamentos através de circulação e até coproduções. Claro que se estas redes não tiverem uma organização legal, clara e aberta ficamos submetidos à sorte ou azar. As redes de programação deveriam ser legalmente constituídas com uma organização clara com igual oportunidade para todos. $O$ que não acontece neste momento. Se as redes estiverem claras e abertas pode-se muito facilmente conjugar as circulações entre teatros com o financiamento às artes.

[70 - outra área, teve apoio]

6 A articulação com redes de programação é muito importante e deveria ser promovida pela DGArtes, através do estabelecimento de protocolos. Este aspecto é fundamental para a obtenção de receitas próprias.

[424 - música, teve apoio]

6 Ainda, penso que é importante que esta integração nas redes de programação seja potencializada quer pelas redes quer pela DGArtes. Isto quer dizer que, na minha opinião, não devem ser os artistas a "andar atrás" destas possibilidades. Imagino a criação de uma possibilidade em cada candidatura para assinalar se o grupo ou artista candidato está disponível para se apresentar no âmbito da rede e quais as condições para isso. Depois, os programadores poderem ter acesso às candidaturas vencedoras e decidir o que querem programar, havendo a obrigatoriedade de programar um certo número de atividades neste âmbito.

[42 - música, teve apoio] 
66 poderia ser interessante para uma eventual itinerância; Contudo a nossa experiência foi sempre bastante frustrante. Em primeiro lugar deveria-se criar um regulamento muito claro para que todos os intervenientes deveria, ser obrigados a cumprir. Demasiadas vezes temos assistido à associação de vários centros de cultura/teatros/Câmaras Municipais que não cumpriram as suas responsabilidades, deixando as entidades artísticas com graves problemas de gestão, quer em termos de assegurar as condições logísticas necessárias, quer quanto ao processamento de pagamento dos honorários acordados. Nunca foi possível ter uma correspondência e uma clareza de sistema por parte dos sujeitos que estavam alinhadas nos projecto.

[296 - música, teve apoio]

66 A nossa opinião é que cada entidade financiada seja obrigada aquando da contratualização do apoio do Estado a realizar um número de espetáculos em teatros ou auditórios. Assim uma parte da verba do apoio do Estado dirá respeito aos cachets desses espetáculos, enquanto aos teatros de acolhimento caberiam as despesas de deslocação, alojamento e alimentação, bem como a promoção/divulgação do espetáculo.

[415 - teatro, teve apoio]

6 As redes de programação são normalmente associadas a entidades de programação dentro das Artes do espetáculo. Não deve ser majorado esse facto por existirem entidades a concurso com projetos não itineráveis ou fora desse perfil. Autonomamente deveria ser criado concurso específico para o efeito, acessível a todas as entidades, com ou sem apoio a decorrer.

[154 - outra área, teve apoio]

66

Deve-se contemplar apenas e tão só acordos de co-produção. Articulação prevista no modelo de apoio às artes com redes de programação tende a uniformizar e a formatar os conteúdos artísticos. Um erro que a Europa está a reconhecer. As redes de programação é que se deverão, caso o queiram, articularse com o modelo de apoio às artes.

[147 - teatro, teve apoio]

66 Chegamos ao que consideramos ser um dos busílis do problema: o timing entre garantir co-produtores e garantir outras fontes de financiamento como um apoio da DGArtes. No dia em que as casas de programação e a DGArtes conseguirem articular um diálogo à volta da produção de projectos e/ou estruturas, no sentido de conseguirmos, todos juntos, acertar os timings dos vários financiamentos, o trabalho de produção (e até de promoção) dos projectos estará largamente facilitado. Como é que isso pode ser feito, não sabemos.

[381 - teatro, concorreu mas nunca teve apoio] 


\section{Financiamento}

As propostas enunciadas a respeito do financiamento das redes de programação têm em comum a necessidade de aumentar o seu montante, mas os objetivos e medidas sugeridas apresentam um espectro muito disperso: redes municipais; linhas de programação específicas; infraestruturas de acolhimento; dispositivos de circulação de projetos.

6 As redes de programação permitem uma economia de escala e, por isso, deverão ser contempladas no modelo de apoio às artes, tendo em conta a limitação de recursos com que sempre nos debatemos.

[288 - música, teve apoio]

6 A não ser que haja reforço significativo de financiamento, o modelo de apoio às artes não deve contemplar a articulação com redes de programação.

[487 - outra área, teve apoio]

64 Por exemplo, a criação de protocolos autónomos ao concurso de apoio às artes, em que as redes de programação possam usufruir de financiamentos específicos para a programação de espectáculos de carácter mais experimental ou de emergentes (pois são os que mais sentem a dificuldade em entrar no circuito de programação).

[489 - cruzamentos disciplinares, teve apoio]

6 O financiamento a redes de programação municipais pode ser uma via para: Apoiar a programação descentralizada . Apoiar a criação de projetos de enfoque local . Garantir uma gestão profissional e integrada dos projetos . Valorizar o pluralismo e a diversidade, diversificando a atividade de acordo com as escalas e as características dos territórios envolvidos. Promover a continuidade dos projetos e garantir o acompanhamento e a avaliação dos mesmos

[476 - cruzamentos disciplinares, teve apoio]

6 Os fundos estruturais do Programa Portugal 2020 deixaram de contemplar o apoio à programação em rede [...]. O Estado deve proporcionar, é certo, digressões nacionais, por exemplo, das suas estruturas de criação. Mas com os parcos meios de que a DGArtes tem disposto para o apoio à criação artística, como apoiar ainda a programação em rede?

[470 - teatro, teve apoio] 
6 A articulação com redes de programação pode ser feita a dois níveis: 1) dotar de recursos financeiros os diferentes teatros existentes no território nacional no sentido de lhes permitir co-produzir espectáculos, contrariando a concentração excessiva destes co-produtores nos grandes centros urbanos; e 2) criar mecanismos de financiamento às entidades artísticas beneficiárias dos apoios da DGArtes (pontuais, plurianuais, etc) que lhes permitam apresentar os seus trabalhos no maior número possível de teatros, na medida em que essas entidades artísticas demonstrem capacidade de interessar os respectivos programadores nos seus trabalhos já produzidos.

$$
\text { [464 - teatro, teve apoio] }
$$

6

O estado central deveria apoiar, com uma linha de financiamento distinta de programação, os equipamento culturais que proliferam fora das áreas de Lisboa e Porto, e premiar (à semelhança dos demais concursos) a qualidade da proposta de programação a ser financiada. Esta medida iria criar mais interlocutores locais com os quais poderíamos falar, com uma gramática e vocabulário semelhantes.

[240 - teatro, teve apoio]

\section{Mercado}

\section{Rede de teatros e cineteatros}

Na âmbito da reflexão sobre redes de programação, algumas entidades defendem a implementação efetiva da rede de teatros e cineteatros municipais como elemento central da política pública para o sector.

66 É fundamental implementar um efectivo funcionamento articulado da rede de teatros e cine-teatros. Não faz qualquer sentido a legislação de apoios privilegiar a descentralização, e praticamente não existir um "mercado" nacional e muitas vezes um total desinteresse das autarquias que gerem os teatros municipais, por projectos e actividades apoiadas no quadro dos apoios quadrienais, bienais e pontuais.

[244 - cruzamentos disciplinares, teve apoio]

6 Deveriam ser atribuídas quotas (através de um caderno de encargos rigoroso ao nível da comunicação e das exigências técnicas e artísticas) para apresentação de projectos apoiados pela DGArtes, na rede de teatros municipais.

[388 - cruzamentos disciplinares, teve apoio] 
66 É absolutamente essencial envolver a autarquia nos processos de apoio. No entanto, numa situação ideal onde, na região, exista um Cine-Teatro a funcionar com um projecto de qualidade, seria ideal que a relação passasse igualmente pela articulação com este teatro. Somos da opinião que, após uma fase de transição em que os Cine-Teatros fossem dotados de uma equipa de direcção e programação mais profissional, o relacionamento, na região, deveria ser transferido para esta estrutura em detrimento da autarquia.

[418 - cruzamentos disciplinares, teve apoio]

66

Pensamos que a Rede de Teatros deve ser objeto de apoio do Estado por meio concursal, ficando estes Teatros obrigados pelo próprio concurso, a criar uma rede de circulação de espetáculos com as entidades apoiadas pela DG Artes.

[361 - cruzamentos disciplinares, teve apoio]

6 A esse respeito, sugerimos que seja dada mais importância à programação da rede de teatros e cine-teatros que existe no país e cuja gestão corrente está sob a alçada da administração local. A DGArtes poderia criar uma bolsa de espectáculos apoiados que circulassem pelo país, potenciando essa rede. Para mais, a administração local, dada a relação de proximidade, deve ser um promotor da formação de públicos e incentivar a ocupação dos espaços dos teatros e cine-teatros também por parte de companhias locais.

[360 - teatro, teve apoio]

\section{Medidas de incentivo à circulação}

As medidas concretas de incentivo à circulação podem agrupar-se em três tipos: para os projetos de criação apoiados, contratualizar (ou determinar como requisito de candidatura) a apresentação obrigatória em equipamentos públicos distribuídos pelo território; para redes/equipamentos de programação, definir quotas obrigatórias de apresentação de projetos de criação apoiados em concurso público; estabelecimento (ou recuperação) de programas públicos específicos dirigidos à circulação pelo território nacional de produções artísticas beneficiárias ou não de apoio público.

66 modelo de apoio às artes devia obrigar à articulação de todos os projetos apoiados em rede. Ou seja, não concebemos que não haja uma ligação entre esses apoios e redes formais e informais a nível nacional. Normalmente a lógica está invertida: os concorrentes a apoios devem apresentar já digressões, mas o contrário também deve acontecer. Projetos financiado pelo estado devem 
circular de forma obrigatória pelo território. Para isso é necessária a coordenação com os teatros municipais.

[303 - cruzamentos disciplinares, concorreu mas nunca teve apoio]

66 O modelo de apoio deveria contemplar a articulação com redes de programação servindo os serviços da DGArtes de elo de ligação entre Entidades/Redes de Programação.

[63 - dança, teve apoio]

66 Já anteriormente referi que as direcções regionais deveriam ter um programa em rede nos seus territórios e com as estruturas sediadas nestes. E reforço que seria de grande importância voltar a existir um programa do género a nível nacional, com o envolvimento das autarquias e instituições de programação. Com um concursos mesmo para estas e onde as estruturas a nível nacional pudessem percorrer e mostrar o seu trabalho em todo o território nacional. Este programa deveria ser liderado pela DGArtes em colaboração com as direcções regionais e com um concurso próprio. Deveria ter apenas um plano de comunicação de forma a chegar melhor e a mais gente alem de claro minimizar os custos. As questões técnicas deveriam ser da responsabilidade das instituições locais (que fizessem parte do projecto) e deveria este programa ser apoiado pela radio e televisão do estafo, dando visibilidade não só ao trabalho dos envolvidos mas também ao trabalho da DGartes e do próprio Ministério da Cultura. Um programa do género minimiza as assimetrias, divulga os criadores e as artes e pode colocar o País em destaque perante os públicos internacionais.

[52 - música, nunca concorreu]

66 Talvez fizesse sentido pensar numa forma da programação em rede que acontece no país levada a cabo por municípios ou as suas estruturas tivesse de incluir as estruturas apoiadas pela DGArtes.

[277 - música, teve apoio]

66 Em tempos, a DGArtes teve um programa que, passando por diversas designações (Território Artes, e outras), "triangulava" relações entre os agentes culturais, as autarquias e a própria DGArtes. Um mecanismo semelhante que viesse a ser implementado poderia, cremos, ser importante para aumentar o número de acções realizadas em parceria com as autarquias.

[108 - música, teve apoio]

6 Deve contemplar a articulação na medida em que permita potenciar maior circulação de projectos e eventualmente possibilitar a apresentação pública de 
projectos entretanto apoiados apenas para criação. A ter em conta a possível recuperação do Programa Território Artes.

[511 - cruzamentos disciplinares, concorreu mas nunca teve apoio]

\section{Internacionalização}

O estudo inclui a dimensão da internacionalização com três questões: uma sobre os projetos a apoiar pela DGArtes, pergunta fechada, de resposta múltipla, com cinco opções de resposta previamente definidas; outra que solicita a fundamentação da opção, ou opções selecionadas; e uma terceira sobre o que deverá ser a atuação da DGArtes relativamente aos projetos internacionais em rede, esta de resposta aberta ${ }^{45}$.

Quanto aos projetos a apoiar pela DGArtes a circulação é a que se destaca com $78 \%$ das respostas expressas (gráfico 17). Num patamar substancialmente mais baixo situam-se formação (59\%) e residências (55\%). Com menos de metade, situam-se plataformas e convites a programadores e/curadores (41\%). Outros projetos, opção de resposta aberta, reúne ainda assim a preferência de $17 \%$ das entidades inquiridas.

\footnotetext{
${ }^{45}$ Q29. Considerando a experiência da entidade, que projetos de internacionalização deverão ser contemplados pela DGArtes? (assinale as opções que mais se adequam): circulação de projetos; residências; formação; plataformas e convite a programadores/curadores; outros: quais? A taxa de resposta é $91 \%$.

Q29.1 Por favor fundamente a resposta. A taxa de resposta é $64 \%$.

Q30. Ainda considerando a experiência da entidade, qual deve ser o posicionamento da DGArtes no caso específico dos projetos internacionais em rede? Se considerar relevante especifique que atividades deverão ser apoiadas. A taxa de resposta é $57 \%$.
} 
Gráfico 17. Projetos de internacionalização a contemplar nos apoios

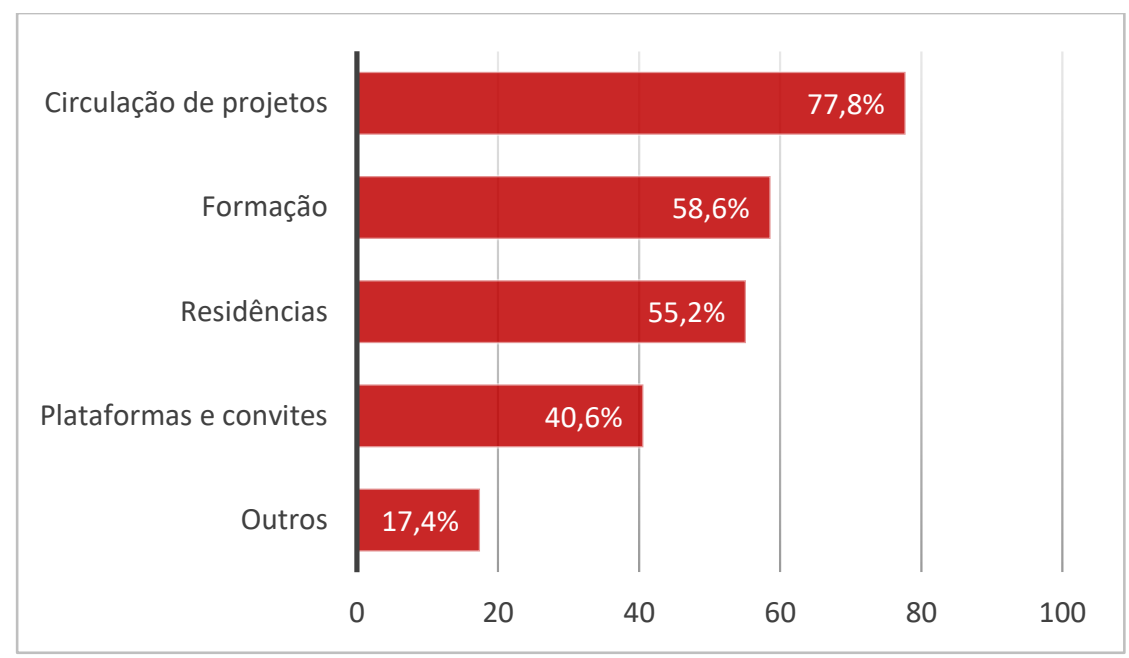

( $n=522$, resposta múltipla)

Fonte: CIES-IUL, EPEA, 2017.

Importa ter em conta que a questão é de resposta múltipla. Uma parte relativamente pequena das entidades assinalou apenas uma das opções (15\%), ao passo que sensivelmente o dobro (30\%) assinalou as cinco opções, ou pelo menos quatro delas, excluindo a opção outro.

As fundamentações expressas destacam a relevância da internacionalização, em várias vertentes: para cruzar experiências e enriquecer os projetos; porque deve ser vista como uma prioridade, até do ponto de vista da projeção da arte e dos artistas nacionais; para promover relações de trabalho. Contudo, esta vertente, se bem que em geral positivamente equacionada, coloca ainda assim certas reservas a algumas entidades, numa chamada de atenção para que nem todas têm de ter esta vertente.

6 Todos [as cinco opções] acima [indicadas] pois cremos ser fundamental a contaminação de diferentes experiências e pensamentos sobre a arte.

[2 - teatro, nunca concorreu] 
66 Todas as [opções] seleccionadas são fundamentais para o desenvolvimento $\underline{\mathrm{e}}$ enriquecimento de qualquer projecto. Trazendo assim outras visões, pensamentos e soluções para as dinâmicas gerais do meio cultural em que se inserem.

[8-cruzamentos disciplinares, nunca concorreu]

66 Num mundo cada vez mais globalizado, fechar-nos no nosso canto não é nem interessante nem produtivo. Os desafios que se põem às artes hoje, são os desafios de uma sociedade que se vê, por um lado, cada vez menos sem fronteiras e, ao mesmo tempo, cada vez mais dividida. A aposta na formação, nas trocas interculturais, no conhecimento e trabalho em realidades outras tornaria todo o trabalho mais rico e serviria de cimento na construção de uma sociedade bem mais humanizada

[16 - teatro, nunca concorreu]

66

O apoio á internacionalização deve ser uma pedra angular da presença dos agentes da cultura artística nacional em plataformas e condições que potencial a valorização do seu trabalho.

[136 - artes plásticas, nunca concorreu]

6 Os projetos de internacionalização, com sustentabilidade, implicam conhecimento e reconhecimento de partes entre si pelo que convidar programadores e curadores faz tanto sentido como apoiar deslocações de artistas e de programadores nacionais a outros países, europeus e de países terceiros; residências e formação sobre a forma de workshops, por exemplo, estimula e facilita a criação de cumplicidades artísticas facilitando a criação de projetos de raiz internacional; circulação de projetos parece ser a consequência lógica de todo o esforço. Todos as formas são válidas e úteis mas a estratégia será responsabilidade política - o que pretende o M[inistério] Cultura com a internacionalização? O que desejam os criadores com a internacionalização? No nosso caso desejamos estabelecer relações de trabalho continuado com Marrocos, Cabo Verde, São Tomé e Príncipe, Moçambique. Com formação, residências, espetáculos e circulação dos mesmos...

[147 - teatro, teve apoio]

66 A circulação de projetos porque permite transportar conceitos e ideias para fora de território nacional. Funciona como uma projeção de imagem da entidade e, simultaneamente, da identidade nacional. A curto prazo tem reflexos ao nível do turismo. As residências porque permitem o fluxo conceptual e artístico. A partilha de novas experiências com resultados garantidamente profícuos. As plataformas e convite a programadores/curadores porque permite criar diversidade nos projetos através de novas perspetivas e novos valores. Ao 
nível da formação porque é partilhado conhecimento e experiências. É possível adquirir novas formas e metodologias de trabalho.

[269 - artes plásticas, teve apoio]

66 Todos os incentivos à internacionalização parecem-nos correctos. Porém, não deveriam criar a ideia de que todas as entidades deveriam ter uma componente internacional. As características de cada projecto é que devem ditar a forma de o apoiar, por oposição aos apoios ditarem - de forma mais aberta ou mais velada - a forma como estes devem agir.

[528 - teatro, concorreu mas nunca teve apoio]

\section{Circulação de projetos}

As fundamentações da opção pelo apoio à circulação de projetos destacam, entre outras temáticas, a sua importância para a divulgação das obras, a troca de experiências, a circulação em festivais, a difusão dos produtos das indústrias culturais. Destaca-se também o impacto na visibilidade da criação portuguesa e a importância de novos mercados. Colocam-se alguns limites, designadamente não tornar a preocupação com a internacionalização excessiva no quadro das políticas para a cultura.

66 Na nossa experiência a circulação de projetos é muito importante e bastante abrangente, pois efetivamente possibilita a divulgação de obras e artistas, troca de saberes e experiências que contribuem para a criação e outros intercâmbios.

[331 - arquitetura, teve apoio]

6 Relativamente à Circulação de projectos, gostaríamos de referir um aspecto pertinente, que se prende com a participação em festivais internacionais. Consideramos que deve ser devidamente avaliada a qualidade dos festivais, a que uma estrutura se candidata.

[305 - cruzamentos disciplinares, teve apoio]

G A circulação de espetáculos e a formação é a que mais se adequa a este tipo apoio.

$$
\text { [191 - teatro, nunca concorreu] }
$$

6 A indústria cultural portuguesa pode vir a ser auto-sustentável se se promover amplamente a difusão da nossa Cultura no âmbito. Atualmente nunca se sabe 
se podemos angariar artistas que vão fora de portas, pois não sabemos se há fundos que, pelo menos numa fase inicial, possam permitir os "bons" investimentos que produzam frutos. Veja-se o que se faz há décadas com a captação de turistas e vejam bem os resultados. Era isso que se devia fazer na Cultura.

[204 - música, concorreu mas nunca teve apoio]

6 A circulação de projetos como instrumento de visibilidade e valorização da criação artística nacional a nível internacional parece-nos o principal desiderato que os financiamentos à internacionalização devem considerar, por razões óbvias: quantos mais projetos nacionais tiverem possibilidades e apoios para se mostrarem além fronteiras, por maioria de razão, maior e de mais qualidade será a imagem das artes portuguesas. Por outro lado, o investimento em iniciativas de formação, quer com convidados estrangeiros para que deem formação em Portugal, quer com criadores e formadores portugueses a disporem de mecanismos de financiamento para darem formação no estrangeiro, são investimentos na qualificação dos agentes culturais portugueses que ainda apresentam grande potencial de desenvolvimento.

[506 - teatro, teve apoio]

6 No caso da internacionalização das artes, penso que o mais importante é promover a arte de caracter nacional nos meios internacionais. Promover autores, interpretes e performers.

[314 - música, concorreu mas nunca teve apoio]

6 A circulação de projetos parece ser a mais adequada aos desígnios da internacionalizaçõ. No entanto, o inverso pode ser também importante, i.e. o apoio a projetos nos quais exista uma componente de convite a criadores estrangeiros pode ser também eficaz do ponto de vista da internacionalização.

[11 - artes plásticas, nunca concorreu

66

O apoio à internacionalização deve promover a circulação de projectos já existentes, para outro tipo de actividades existem actualmente outro tipo de apoios (Europa Criativa, Erasmus...)

$$
\text { [28 - música, teve apoio] }
$$

6 As nossas escolhas estão interligadas. E pensamos que só assim faz sentido a internacionalização, estamos num mundo global e onde cada vez existe um publico maior para as áreas da cultura. Porem Portugal pela sua própria dimensão não consegue ter expressão internacionalmente na área a cultura visto que os criadores e as estruturas têm dificuldade de chegar aos programadores internacionais. Quando chegamos somos bem aceites e conseguimos louvores de quem esta nesses territórios. Dai a importância de serem criados programas 
em rede que colocassem em circulação os projectos portugueses. Este é o tipo de internacionalização que pode dar frutos. Projectos pontuais hoje aqui hoje alem, hoje deste criador hoje do outro não conseguem a visibilidade de uma rede. A analise da forma de trabalho na área da internacionalização dos brasileiro pode ser um ponto de partida no caso de duvidas, eles são a par dos norte americanos aqueles que melhor trabalho tem feito nesta área, dai o conhecimento que o mundo tem de todas as suas áreas artísticas e dos seus criadores. Estas redes e circuitos poderiam ser pensados com o apoio das nossas embaixadas e estruturas institucionais portuguesas no mundo.

[5- música, nunca concorreu]

66 As outras áreas parece que podem arranjar outros tipos de apoios - nas universidades, fundações, etc... - a circulação de projectos é o campo mais vulnerável.

[59 - outra área, nunca concorreu]

66 Sendo todas áreas significativas, mas tendo em conta a necessidade de escoIher prioridades, diria que a circulação de projectos é, como já expresso no Q15, a vertente da internacionalização mais importante. Apoiar a circulação internacional dos projectos é uma medida fundamental para dar sentido ao investimento na produção artística e à sua visibilidade.

[490 - artes plásticas, teve apoio]

66 Pela nossa experiência a prioridade estará em criar condições para que os projectos possam chegar a outros países em condições de concorrência, nas mesmas condições com que chegam projectos de entidades de outros países, baixando custos de produção/deslocações, etc.

[419 - música, teve apoio]

G6 Devem ser contemplados projetos que efetuem intercâmbio de culturas, dando a conhecer a cultura portuguesa a outras culturas e vice-versa.

[323 - música, nunca concorreu]

6 Depende das verbas disponíveis: havendo poucos recursos financeiros o fundamental é a circulação de projetos, já que são potenciadores de outros espetáculos, de novas encomendas, de criticas, de conhecimento de projeção artística a nível internacional e de reconhecimento. $\mathrm{O}$ convite a programadores/curadores é discutível já que sobretudo na Europa as instituições culturais têm normalmente verbas para enviar os seus porgramdores e muitas vezes (já assistimos a isso) há estruturas em Portugal que convidam programadores/curadores que não aparecem nos espetáculos, que vêm tão somente passar férias.

[480 - música, teve apoio] 
66 Creio que é importante internacionalizar projectos, mas não creio que uma excessiva política de internacionalização seja benéfica, pois desloca verbas da actividade nacional.

[73 - teatro, concorreu mas nunca teve apoio]

\section{Residências}

Parcerias com entidades, plataformas ou estruturas internacionais, a importância para os criadores e a criação da troca de experiências, a importância de apoio a estes projetos para viabilizar experiências positivas, do ponto de vista da criação ou da entrada em novos mercados.

66 Estabelecer parcerias com entidades promotoras e plataformas de residências artísticas (nacionais e internacionais) em todas as áreas artísticas parece-me fundamental. Fazer projectos com elas e divulgá-los bem, de maneira a que toda a gente possa saber da existência de mais possibilidades de desenvolver e mostrar trabalho.

[30 - outra área, nunca concorreu]

6 As residências artísticas são fundamentais para a criação, e ao mesmo tempo podem ajudar a criar programação e formação, para nós são 3 em 1! Os intercâmbios permitem abrir horizontes - trocar experiências = crescer!

[23 - música, concorreu mas nunca teve apoio]

66 É essencial que os nossos autores/dramaturgos possam participar em residências artísticas de escrita.

[115 - teatro, concorreu mas nunca teve apoio]

6 Pensamos que a ligação a estruturas internacionais será potenciada sob a forma de residências artísticas que tragam mais valias para os projetos concretos.

[94 - cruzamentos disciplinares, concorreu mas nunca teve apoio]

6 apoio aos artistas fazedores, não às redes que sugam os poucos apoios que estes eventualmente auferissem

[96 - artes digitais, concorreu mas nunca teve apoio] 
6 Temos feito alguns intercâmbios internacionais que são muito importantes na troca de experiências e culturas. O problema são os custos que muitas das vezes são incomportáveis como deslocações e alojamentos.

[97 - música, nunca concorreu]

6 A internacionalização é claramente uma forma de fazer circular projectos ou de formação no exterior, mas pensamos que é claramente uma forma de partilha de conhecimento e de experimentação. Esta deve permitir o fluxo de conhecimento e de experiência entre entidades estrangeiras e nacionais para um trabalho e uma investigação transdisciplinar e aprofundado, centrado numa sociedade e num mundo sem fronteiras.

[346 - design, concorreu mas nunca teve apoio]

66 [...] No nosso caso, como exemplo, a única forma de se entrar no mercado internacional de circo contemporâneo é fazer residências noutros países. Temos vários espaços para nos acolher mas não temos dinheiro para suportar gastos de deslocação e estadia e muito menos legitimidade para ter os artistas fora de casa quando os valores que conseguimos pagar estão em tudo longe do que deveriam ser. As equipas artísticas são muito reduzidas para o projeto sobreviver e isso faz com que não haja nem dinheiro nem equipa para representações no estrangeiro. Poderia ser criada uma equipa de um organismo associado ao estado que fizesse esse trabalho de promoção e o contrário, organizar cá mostras para programadores.

[70 - outra área, teve apoio]

G6 Considerámos um factor de enorme relevo, a colaboração com artistas de diferentes origens para enriquecimento dos métodos através da partilha de conhecimento.

[74 - outra área, concorreu mas nunca teve apoio]

66 Já anteriormente justifiquei porque é que tem de apoiar residências artísticas. Vou repetir: é fundamental para os artistas darem o seu trabalho a conhecer no estrangeiro e fazer networking a nível internacional. Ou seja podermos nos candidatar a bolsas para podermos fazer residências.

[5 - artes plásticas, nunca concorreu] 


\section{Formação}

A vertente da formação é defendida pelo contacto com boas práticas, quanto a artistas, mas também a outros profissionais dos mundos artísticos e a estudantes, designadamente pela influência em projetos nacionais. Refere-se ainda neste âmbito a investigação e sugerem-se apoios sob a forma de bolsas.

66 No nosso caso trabalhar com outras experiências, novas/outras boas práticas é de extrema importância para o processo de aprendizagem na produção artística.

$$
\text { [27 - música, teve apoio] }
$$

6 No nosso caso, a internacionalização não tem um enfoque muito grande, uma vez que os nossos objetivos e parâmetros de atuação são mais regionais. Pelo menos, para já, e em primeiro lugar, a nossa missão passa mais por cativar público local. No entanto, projetos que incluam a formação dos nossos colaboradores (artistas e staff) poderiam ser uma enorme mais valia, bem como o movimento oposto de formação.

[277 - música, teve apoio]

6 Da experiência da nossa actividade [...] centra-se em realizar processo de pesquisa e criação que são em si o "produto" final. Ou seja, no nosso caso não se aplica fazer a circulação internacional de "espectáculos" fechados mas sim de processos formativos, investigação in loco, criação com...

[24 - outra área, teve apoio]

6 A troca de experiências e de saberes é o que mais pode potenciar a internacionalização. A mostra de projectos é mais onerosa e pouco rentável ou interessante. Muitas vezes reflecte circuitos irrelevantes e mal pagos. Ir passar um tempo ao estrangeiro e não corresponder a verdadeia partilha ou projectos serve para quê?

[217 - teatro, teve apoio]

6 A internacionalização insere-se num ponto fulcral: a divulgação da cultura e da língua portuguesa. A formação e troca de formações tem de estar sempre presente, sempre.

[261 - teatro, nunca concorreu]

6 Os projectos apoiados deverão estar centrados na actividade dos artistas e dar resposta às duas maiores lacunas dentro do território nacional: a visibilidade 
das obras e a diversificação da formação. Consideramos igualmente importante o apoio ao convite a programadores internacionais, mas não tanto directamente às plataformas, visto que a grande dimensão das poucas plataformas que existem pode impedir outros agentes de realizar idêntico trabalho apoiando outros criadores.

[376 - dança, teve apoio]

66 A formação e a circulação de projetos de internacionalização, são em minha opinião os que maiores frutos poderão dar, a nível de formação, a oportunidade de conhecer e formar novas linhas de pensamento, conhecer novas realidades que poderão beneficiar a criação nacional. Na circulação de projetos de qualidade, a oportunidade de demonstrar fora de portas, o trabalho que se desenvolve, potencializado e dignificando o "produto nacional".

[362 - música, nunca concorreu]

66 A importância do apoio à Investigação já foi descrita e fundamentada anteriormente. Saliento que mais nenhum órgão em Portugal, além da DGArtes, deveria manter presente a responsabilidade de salvaguarda e promoção dos centros de investigação e investigadores dedicados às áreas culturais pois a Fundação para a Ciência e Tecnologia está hoje, mais do que nunca, maioritariamente focada nas áreas ligadas ao desenvolvimento tecnológico e das ciências exatas, tendo abandonado progressivamente nos últimos anos o apoio e reconhecimento aos projetos de caráter cultural. Ora serão sempre os investigadores e suas teses os principais autores da crítica sustentada, do registo e da discussão de todas as temáticas que compõem uma atividade. Sem estes agentes qualquer área estagnará e correrá o risco da ausência de originalidade, da prosperidade e sucesso.

[478 - cruzamentos disciplinares, concorreu mas nunca teve apoio]

66 Todas elas são entretenimento dos que as auferem... A pior opção é colocar programadores e cuadores (parasitas) a dirigir o processo, depois também mau são as plataformas... Mas nenhuma das opções é boa. A melhor hipótese é a tradicional: Bolsas de estudo para os artístas - para frequentarem algo...

[50 - artes plásticas, nunca concorreu]

\section{Plataformas e convite a programadores/curadores}

Os posicionamentos que assinalam esta opção da internacionalização por via das plataformas e o convite a programadores/curadores chamam a atenção para a crescente importância das coproduções internacionais no financiamento comunitário, o que parece contrastar com as carências artísticas em Portugal. Plataformas que aumentam a visibilidade e facilitam a angariação de parceiros. 
Destaca-se a internacionalização pelas plataformas na perspetiva interior-exterior, mas também em sentido contrário. O papel potenciador dos programadores/curadores que contactam com projetos nacionais, a multiplicação das oportunidades para que tal aconteça e o papel da DGArtes como mediadora nesses processos são igualmente destacados.

6 As coproduções internacionais vêm adquirindo uma importância cada vez mais significativa dentro e fora do quadro de financiamento comunitário, e que, portanto, acabam por se tornarem em mais uma opção das entidades para as suas atividades. Esta opção é tanto mais importante na medida em que as coproduções, a nível nacional, deixaram de poder existir como uma possibilidade de produção. Embora consideremos que para algumas atividades artísticas as residências sejam um forma de produção, a circulação de projetos, bem como a existência de plataformas com convites a programadores, são, desde há muito, uma das grandes carências a nível nacional. 0 esforço efetuado por várias entidades aos longo de dezenas de anos para que haja uma plataforma - do tipo Feira - foi sempre impossível de levar a cabo pelas mais diversas razões. É urgente concretizar uma plataforma que funcione como uma montra de artes cénicas, onde a circulação nacional e internacional seja o objetivo prioritário.

[175 - teatro, teve apoio]

6 Consideramos muito importante poder corresponder aos convites que nos são feitos para apresentação dos nossos espetáculos em Plataformas Internacionais, para o que o apoio da DGArtes poderá ser indispensável. Do mesmo modo, receber programadores internacionais nas nossas plataformas deverá constituir um impulso muito importante para dar continuidade à internacionalização dos nossos artistas.

[363 - dança, teve apoio]

66

Plataformas: Por além do interesse comercial para as entidades Portuguesas, as Plataformas internacionais são ocasiões preciosas para criar contactos, relações, iniciar redes internacionais. São essenciais pelo desenvolvimento de todos os setores.

[474 - cruzamentos disciplinares, teve apoio]

G6 A apresentação do espectáculo no circuito internacional permite que seja visto numa plataforma maior e que seja possível encontrar mais facilmente parcei-

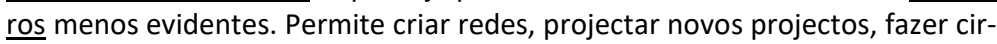
cular artistas e ideais. As plataformas e os convites a programadores/curadores permite às estruturas e artistas que não possam apostar/investir na circulação de projectos, tenham um plataforma onde possam apresentar o seu trabalho 
e criar assim as condições para futuros convites para participações em festivais no estrangeiro.

$$
\text { [280 - teatro, teve apoio] }
$$

G6 É fundamental divulgar os criadores portugueses, potenciando a divulgação com convites a programadores e plataformas de programação pela DGartes e ministério da cultura como fazem nos outros países europeus.

[373 - teatro, teve apoio]

6

[...] A nossa experiência neste momento diz respeito a uma primeira tentativa de internacionalização que derivou de duas iniciativas que nos foram alheias: o convite a programadores estrangeiros que partiu de uma outra companhia e um convite directo de uma instituição estrangeira à nossa companhia, por recomendação de um programador português em ligação com um festival francês. Conseguimos, portanto, avançar para o plano internacional sem necessitar do apoio da DGArtes, tendo a companhia suportado os custos de uma versão em língua estrangeira, no caso francesa. No entanto, sem a oportunidade de entrar no circuito de programação por via dos programadores, teria sido praticamente impossível mostrar o trabalho fora do território nacional. Isso mesmo tinha sido tentado pela companhia, através de inúmeras cartas e inscrições em festivais europeus. Resultou evidente que sem uma recomendação particular, não se entra no circuito internacional. Esse papel, de criar oportunidades para mostrar o trabalho, convidando programadores, criando mostras, festivais, encontros, residências, reflexão e apoiando os projectos financeiramente de modo a torná-los economicamente mais apetecíveis para instituições estrangeiras - deve ser promovido pela DGArtes, senão directamente, pelo menos apoiando os agentes culturais que o possam e queiram desenvolver.

[62 - teatro, teve apoio]

\section{Outros projetos}

São várias as linhas de projetos telegraficamente mencionados na fundamentação da escolha da opção "outros projetos": coproduções; cocriações; investigação, participação em encontros científicos; exposições; parcerias; participação em feiras internacionais; deslocação a festivais; viagens internacionais de prospeção. Entre os contributos vários há os que explicitam mais detalhadamente possíveis projetos e avançam a sua fundamentação: edições, traduções, arquivo, feiras. Alguns delimitam prioridades na vertente da internacionalização, destacando-se aqui o espaço lusófono. 
66 A internacionalização deve ser vista como uma prioridade. Como tal, deverá contemplar as várias áreas de intervenção. A penetração das nossas edições por exemplo musicais no mercado externo é quase nula, mesmo naqueles de língua portuguesa e de línguas latinas. Devem ser criadas estratégias para aumentar a exportação de edições fonográficas, videográficas e outras.

$$
\text { [41-música, nunca concorreu] }
$$

66 Não deve ser contemplada apenas a circulação de projectos. No caso de um projecto de artes digitais e de edição digital deveria ser incentivado e reconhecida a importância de edições bilingues que difundem a arte a cultura portuguesa no estrangeiro a partir de plataformas realizadas em Portugal.

[508 - artes digitais, teve apoio]

6 Não falo por experiência da minha entidade, mas por experiência de iniciadora do projeto [...] e a experiência que adquiri em outras situações: Com as possibilidades abertas pela internet na circulação de informação e imagens, o convite a programadores para virem assistir a espetáculos passou a ser quase um luxo desnecessário. As plataformas de apresentação de showcases destinadas a programadores/curadores existe com sucesso mas apenas para alguns géneros musicais altamente lucrativos, como a worldmusic por exemplo. Outros géneros e disciplinas podem beneficiar da participação em Festivais internacionais que creio estarem contemplados no quesito Circulação de Projetos. Quanto à tradução de peças portuguesas para outras línguas, creio ser uma aposta essencial para a divulgação e o desenvolvimento da dramaturgia contemporânea portuguesa.

[162 - cruzamentos disciplinares, concorreu mas nunca teve apoio]

Seria muito importante que existisse um arquivo/base de dados constantemente actualizado, em português e inglês, das Artes Performativas portuguesas, que constituiria uma excelente ferramenta de consulta, não só interna, mas sobretudo para os parceiros internacionais. Por outro lado seria importante apoiar a presença portuguesa em mostras internacionais tais como o $\mathrm{Cl}$ NARS, a TANZMESSE, etc...

[418 - cruzamentos disciplinares, teve apoio]

64 Apoio à realização de feiras ou encontros nacionais e internacionais que promovam as artes portuguesas e seus artistas.

[488 - teatro, teve apoio] 
66 Intercâmbios/redes, co-produções internacionais, programa de bolsas de estágio que permita a circulação individual de artistas - actores, cenógrafos, encenadores, etc. - sem discriminação de idades, em especial entre os países de língua portuguesa.

[498 - teatro, teve apoio]

\section{Posicionamento da DGArtes quanto a projetos internacionais em rede}

Uma possível leitura dos contributos dirige-se à estratégia a seguir pela DGArtes, de intermediação: de incentivo, como facilitadora, no apoio a um gabinete específico, de desenvolvimento de plataforma específica, de representação institucional internacional. Os programas internacionais, designadamente europeus, de grande dimensão (como o Europa Criativa) são exemplos destacados pela exigência e pela desadequação/dificuldade do tecido artístico português para neles se integrar. Outras vão no sentido de garantir condições de digressão internacional, de presença em redes internacionais. A criação de gabinetes interministeriais e um papel mais interventivo da DGArtes em articulação com outros ministérios e organismos implicados nas relações internacionais no âmbito de uma política cultural de internacionalização são também referidos.

66 Pensamos que o papel da DGArtes deve ser mais de incentivador. A rede pode ser criada pela dgartes mas se for criadas pelas entidades pode ser mais eficaz e verdadeira. Uma não invalida a outra mas achamos que se a entidade faz algumas escolhas parte-se do principio que lhe interessa mais logo mais focada.

[208 - artes plásticas, nunca concorreu]

66 O papel da DGArtes e do Estado deve ser de facilitador. É possível estabelecer prioridades estratégicas do Estado que podem ser desenvolvidas em colaboração com estruturas e artistas, mas não devem ser exclusivas. A formação deve ser estabelecida enquanto prioridade.

[244 - cruzamentos disciplinares, teve apoio]

G6 Entendemos que este poderá ser um modelo ideal: a avaliação internacional (e muito competitiva) garantirá critérios minimos de qualidade para projectos aprovados pela UE.

[144 - artes plásticas, teve apoio] 
66 Já tivemos vários convites de estruturas internacionais para desenvolvimento de projetos em Portugal. Deveria haver um gabinete que permitisse saber a viabilidade de apoio numa situação destas sem termos que aguardar abertura de concursos, por exemplo.

[124 - artes plásticas, nunca concorreu]

66 Os projetos internacionais em rede padecem, por norma, da fragilidade das entidades com quem se relacionam. Somos da opinião que a DGARTES poderia ser a dinamizadora de uma plataforma de parceiros internacionais para o desenvolvimento de projetos internacionais.

[269 - artes plásticas, teve apoio]

6 Representação internacional da DGArtes em certames que possam influenciar as dinâmicas de criação e circulação dos agentes culturais nacionais.

[105 - outra área, concorreu mas nunca teve apoio]

66 A DGArtes, como entidade representante do estado português, deveria mediar a informação e contatos entre estruturas.

[70 - outra área, teve apoio]

66 Em suma: mais do que apoios a projetos internacionais em rede, uma política de internacionalização das artes na concessão de apoios a projetos financiados que garantam uma dinâmica de digressão internacional que gere acolhimento e difusão nacional dos grupos dos outros países.

[260 - cruzamentos disciplinares, teve apoio]

6 Muitas das vezes surgem oportunidades de internacionalização com 2 meses de antecedência e aí não há tempo para concursos! Deveria haver um contacto disponível para analisar casos assim que precisam de apoio para concretizar a internacionalizção e por consequência estudar a importância para a carreira deste artista esse apoio.

[127 - cruzamentos disciplinares, concorreu mas nunca teve apoio]

6 A DGArtes deve potenciar a presença de entidades portuguesas em Redes Internacionais - seja em Encontros fora do país quer em actividades realizadas a partir de Portugal. Disponibilizar informação e apoio para candidaturas poderia ser uma forma de apoio, para além do financiamento.

[474 - cruzamentos disciplinares, teve apoio] 
66 Criação de um gabinete próprio, interministerial, dentro ou fora do organismo da tutela que represente o sector das artes, dedicado à internacionalização e à cooperação bilateral. [...] Base de dados dedicada a parcerias, contactos internacionais, links úteis, calls, atualizada regularmente para acesso a apoios, parceiros e eventos internacionais relevantes. [...] Seria interessante que antes de mais, o centro de informação Europa Criativa realmente conheça os problemas das organizações do nosso país. Uma das principais questões que travam a iniciativa das organizações portuguesas prende-se com a indefinição dos apoios a médio prazo. Nem com apoios bienais é possível fazer candidaturas a apoios europeus, o risco é imenso.

[479 - dança, teve apoio]

66 A Dg Artes deveria dar prioridade a projetos internacionais em rede, ou seja deveriam ser premiadas aquelas entidades que demonstrem capacidade de trabalhar em rede a nível internacional, que têm contactos com outras instituições a nível internacional e que tenham curriculum internacional.

[106 - música, teve apoio]

6

Consideramos que a DGArtes deve utilizar os seus recursos em primeiro lugar em prol da criação de estruturas e a sua continuação a nível nacional. A internacionalização deverá ser deixada à iniciativa das próprias entidades e aos respetivos institutos como Instituto Camões e o Ministério de Negócios Estrangeiros. Não consideramos que os recursos limitados da DG Artes devam ser utilizados para apoios de projetos em redes internacionais.

[234 - música, teve apoio]

6

No entanto parece-me que o posicionamento da DGArtes neste caso concreto deveria ser muito mais interveniente, nomeadamente junto das embaixadas portuguesas que muitas vezes ignoram completamente os projectos artísticos portugueses ainda que à partida estes integrem uma rede internacional de parceiros com relevância nos países onde Portugal tem representação diplomática. A minha experiência diz-me que não há qualquer política integrada entre Ministério da Cultura e Embaixadas e comum a todas as Embaixadas. Tudo depende das pessoas e não de uma política intencional de apoio. E a verdade é que muitas vezes o envolvimento da Embaixada de Portugal faz toda a diferença, na agilização de processos, na logística dos projectos nesses países e mesmo na credibilização e relevância dos mesmos, pelo menos junto das entidades do país anfitrião.

[436 - música, teve apoio]

6 A DGArtes deveria estabelecer protocolos e lançar convites e/ou concursos, coligir informação só ao seu dispor (Inst. Europeias, pex), divulgá-las e estimular as entidades para a sua boa execução. Junto do MNE trabalhar activamente 
para a presença constante das nossas artes nos Países onde temos representação. O AICEP faz isso para a área económica. Assumir uma política de circulação internacional. Em rede ou não. A rede também tem uma parcela de moda, amanhã chamar-se-á outra coisa mais moderna.

[261 - teatro, nunca concorreu]

6 Adicionalmente, deve ter-se em conta que o financiamento não é a única forma de impulsionar esta área: devem ser criados canais de acesso diversos que permitam o acesso a oportunidades de internacionalização relevantes; ou seja, em detrimento que mecanismos de "montra" de artistas portugueses, anos comemorativos e efemérides do tipo "país-tema", deve ser elaborada e tornada pública uma verdadeira política de internacionalização que responda a um relacionamento estratégico entre a maturidade dos projectos artísticos, a sua fase de desenvolvimento e aquilo que constituem oportunidades efectivamente relevantes para aquela companhia.

[464 - teatro, teve apoio]

G6 É importante que as experiências de internacionailização tenham uma influênia no tecido cultural como um todo - criando impacto e contribuindo para o desenvolvimento do setor. Ou seja, a internacionalização deve ser parte integrante e fundamental de um conceito de política cultural, contribuindo para deixar rasto no território e promovendo, através da componente internacional, as sinergias locais.

[410 - teatro, teve apoio]

\section{Modalidades de apoio}

Uma das linhas relacionadas com a internacionalização é a eventual maior adequação enquanto apoios pontuais, de menor dimensão, direcionados para necessidades muito específicas.

6 Na opinião da nossa entidade, a DGArtes deve apoiar a internacionalização do artista(ou entidade), através apenas de apoios pontuais para uma determinada actividade com tempo e espaço definidos. Desta forma garante-se que o artista e sua actividade são apoiados sendo estes os beneficiários do apoio.

[102 - arquitetura, nunca concorreu]

6 Pequenos apoios pontuais podem ter um impacto muito mais forte do que grandes operações de circulação.

[128 - arquitetura, concorreu mas nunca teve apoio] 
6 A criação de micro programas de apoio que pudessem, por exemplo, financiar viagens de curta duração ao estrangeiro (para espectáculos, exposições, etc), que funcionassem, por exemplo como assistência à viagem (mesmo que não cobrissem a totalidade da mesma), poderiam ser muito positivas e abranger muita gente.

[500 - música, teve apoio]

Outra linha tem que ver com a experiência do regulamento do apoio à internacionalização, que suscita diversos reparos, quanto à clareza dos procedimentos, aos critérios em que se baseia, ao arrastamento de prazos (por parte da DGArtes) ou à existência de períodos de abertura de candidaturas.

66 Certo é que a maioria dos projetos internacionais em rede, são pouco difundidos e nunca se compreende os procedimentos a ter, nomeadamente em projetos como os EEA Grants p. ex.

[369 - artes plásticas, teve apoio]

66 o concurso de internacionalização tem sido gerido de forma um pouco confusa e contraproducente. Um concurso dessa natureza não se deveria basear em proximidade cultural e/ou territorial consideradas privilegiados (como por exemplo em relação aos Países de língua portuguesa) mas ao contrario deveriam dar importância ao prestigio dos palcos que vão acolher os projectos.

[296 - música, teve apoio]

66 Os procedimentos concursais e o arrastamento de prazos de assinaturas de protocolos e disponibilização de verbas, a incerteza destes mesmos apoios, impedem em grande medida um eficaz trabalho das entidades nacionais em projectos internacionais em rede, que muitas vezes obrigam a uma contrapartida financeira que não têm capacidade para assumir.

[407 - música, teve apoio]

6 Defendemos que não deveriam existir prazos temporais para abrir candidatu-

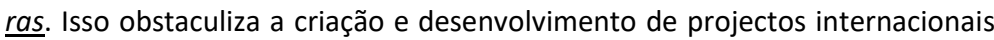
(em rede ou não), cria dificuldades aos parceiros e à programação dos mesmos nos vários países, Defendemos que no final de cada ano deveria ser conhecido o montante financeiro anual, disponível para os próximos $2 / 3$ anos, a constituição do Júri, pelo mesmo período; e os objectivos estratégicos a privilegiar.

[229 - teatro, teve apoio] 


\section{Atividades a apoiar}

Relativamente a atividades a apoiar, muito heterógeneas, cobrem diversos tipos: as despesas a considerar, prioridades quanto à língua, tradução e legendagem em palco, intercâmbios, circulação de artistas por várias estruturas, fóruns internacionais, apoios específicos para candidaturas a projetos europeus estão entre as referidas.

66 Seria também importante que neste caso o apoio possa cobrir também honorarios de criação, Compreendo que este apoio tem necessariamente de incentivar a apresentação e promoção internacional, qualquer apoio À co-criação deverá também passar por promoção e divulgação - o que invariavelmente acontece.

[205 - artes digitais, teve apoio]

6 Viagens, acomodação, todos os seguros de apoio à actividade, per diem, produção de obras, comunicação

[462 - artes plásticas, teve apoio]

66 Consideramos muito relevante o apoio da DGArtes à internacionalização traduzido, por exemplo, no apoio a viagens e estadias das entidades que pertencem a estas redes, bem como pela contribuição no pagamento das respectivas cotas. Isto pode ser feito através do apoio à estrutura (como é o nosso caso) ou através de apoios directos para este efeito. Seria, igualmente da maior importância, que a DGArtes assumisse a contrapartida nacional (na sua totalidade ou em parte), cada vez que uma estrutura conseguisse captar apoios internacionais para projectos, nomeadamente nos concursos promovidos pela Comissão Europeia. Este ponto seria um estímulo importantíssimo para que as estruturas conseguissem captar investimento, nomeadamente europeu, para o nosso país.

[418 - cruzamentos disciplinares, teve apoio]

6 Achamos de suma importância o facto dos agentes culturais terem possibilidade de fazer uma viagem específica, agendando várias reuniões ou reuniões chave. A possibilidade dos agentes culturais fazerem workshops / formações de capacitação é também importante para ir atualizando conhecimentos e ampliar a rede de contatos.

[326 - dança, teve apoio] 
6 Eis, pois, as razões que, entre muitas outras sobejamente reconhecidas, achamos prioritária a definição de uma "linha de prioridade específica" de internacionalização que contribua para a afirmação da identidade linguística, património multicultural com uma matriz primordial no contexto europeu.

[260 - cruzamentos disciplinares, teve apoio]

66 intercâmbio de artistas nacionais e internacionais parece-me particularmente importante. Ao longo dos anos convidei muitos artistas internacionais, e muitos vieram a desenvolver relações com artistas nacionais

[83 - cruzamentos disciplinares, teve apoio]

66 Para além do importante apoio à circulação internacional de projectos portugueses, consideramos importante o estímulo e concertação de projectos que desenvolvam a relação lusófona. A língua portuguesa é um excelente veículo de promoção e aproximação cultural sendo que poderia caber à DGArtes criar um programa de criação/difusão artística dentro do quadro da lusofonia. Neste âmbito poderão estar todas as artes visuais e performativas, uma vez que não existem barreiras para a comunicação.

[413 - cruzamentos disciplinares, teve apoio]

66 A Internacionalização das artes não se prende apenas com a circulação de projectos. Todo o trabalho de pesquisa (formação/criação), divulgação (convites a programadores) e inclusão em redes (criação/apresentação) são fundamentais.

[388 - cruzamentos disciplinares, teve apoio]

6 Além dos projectos internacionais em rede que já existem, seria necessário também implementar um sistema em rede que englobe três ou mais estruturas internacionais em que se implemente encontros, laboratórios, projectos de experimentação que englobem a çirculação de artistas nacionais e internacionais pelas várias estruturas.

[514 - cruzamentos disciplinares, teve apoio]

66 Os forums internacionais das áreas artísticas foram base de desenvolvimento e conhecimento para artistas, gestores e políticos dedicados às artes.

[162 - cruzamentos disciplinares, concorreu mas nunca teve apoio] 
46 Financiamento à tradução e legendagem em palco, de modo a permitir a circulação equitativa de qualquer tipo de obra, que possa recorrer ao uso de texto.

[479 - dança, teve apoio]

66 Consideramos também importante que artistas e programadores integrem comitivas nacionais tal como acontece no sector empresarial. Adicionalmente achamos que seria relevante a constituição de uma base de dados onde fosse disponibilizada informação destinada à internacionalização, quer dos agentes estrangeiros quer dos nacionais para proporcionar potenciais parceiros, apoios existentes, formação, encontros, etc.

[294 - dança, teve apoio]

6 2. Apoio à circulação de criações - internacional a) Linha de apoio dirigida a estruturas e artistas nacionais para a circulação de criações e a realização de residências artísticas portuguesas em território internacional. b) Linha de apoio direto aos teatros e festivais estrangeiros para apresentação de criações portuguesas em território estrangeiro, à semelhança do que fazem outros países. c) Estas linhas de apoio contemplam apoio no máximo de 50\% das despesas de deslocação, estadia, alimentação e cachet de apresentação. 2. Apoio à promoção de criações - internacional a) Criação de três linhas de apoio diferenciadas à logística inerente à promoção internacional: 1 . Linha de apoio dirigida a estruturas nacionais que promovam a vinda de programadores estrangeiros para participar em ações de promoção de criações nacionais (festivais, plataformas, centro de residências/ espaço de trabalho, artistas associados, etc...). Pagamento integral de despesas de viagem e estadia. 2. Linha de apoio dirigida a profissionais nacionais que desenvolvam trabalho na área da difusão internacional, para a realização de viagens de representação. Pagamento integral de despesas de viagem e estadia. 3 . Linha de apoio direto dirigida a programadores de teatros e festivais estrangeiros que pretendam viajar a Portugal, com base no compromisso de contacto com um no mínimo de artistas (pode ser em contexto de festival, centro de residências/ espaço de trabalho, artistas associados, etc...) Comparticipação de despesas de viagem e estadia. d) Criação de uma plataforma bilingue, de uso intuitivo e com as informações básicas sobre cada projeto (artista/ projeto/ sinopse/ teaser/ contacto), para divulgação das criações apoiadas pela DGArtes ou organismo equivalente, a cada ano, lançada no 1 을 ano de existência num conjunto estratégico de eventos internacionais (p.ex.: Bienalle de Lyon, Dance Umbrella, Tanz im August, kfda, Panorama, ...). e) Apoio a plataformas e show cases nacionais e apoio à participação em show cases internacionais.

[479 - dança, teve apoio] 
6 deveria existir um sistema que pudesse apoiar a contrapartida nacional em relação a projectos culturais em rede comunitários (europa criativa...etc).

[296 - música, teve apoio]

66 Uma das modalidades mais utilizada na europa é a troca de maestros entre grupos, criando laços e abrindo a outras parcerias com deslocação dos nossos grupos a festivais ou temporadas europeias.

[282 - música, nunca concorreu]

66 Deveria haver um apoio específico de financiamento para projetos candidatados a apoios Europeus que permitissem que os projetos fossem liderados por estruturas nacionais.

[480 - música, teve apoio]

\section{A vertente dos públicos}

O estudo inclui a recolha de contributos sobre os públicos das artes em três questões articuladas ${ }^{46}$ : uma aberta, dirigida aos modos de valorização (na formulação da pergunta refere-se a sua diversidade e especificam-se os públicos adultos, os públicos infantojuvenis e as comunidades locais). A segunda, sobre como devem ser considerados os públicos no modelo de apoio às artes a partir de um conjunto de 5 opções de resposta (múltipla), é complementada por uma outra em que se solicita a fundamentação da resposta anterior. Embora distintas em termos de formulação, as respostas a estras três questões estão muito frequentemente articuladas entre si. As opções de resposta adiantadas na questão sobre como deve ser considerada esta vertente constituem assim a estrutura organizadora da generalidade dos contributos.

Numa leitura global dos contributos é visível alguma fratura entre os posicionamentos que defendem a valorização dos públicos (na sua diversidade, mas

\footnotetext{
${ }^{46}$ Q31. A diversidade dos públicos (como os públicos adultos, os públicos infantojuvenis e as comunidades locais) vêm ganhando uma relevância crescente. De que modo estas vertentes devem ser valorizadas no modelo de apoio às artes? Por favor fundamente a resposta. A taxa de resposta é $77 \%$.

Q32. No modelo de apoio às artes, a vertente dos públicos deve ser considerada como (resposta múltipla): modalidade de apoio; fator de majoração em candidatura; critério de avaliação; outra solução; não deve ser considerada. A taxa de resposta é $91 \%$.

Q32.1. Por favor fundamente a resposta. A taxa de resposta é $69 \%$.
} 
também na sua especificidade em função do projeto, da modalidade, da localização geográfica das atividades), da receção (e da mediação), por um lado, e a valorização da criação, por outro. Naquela, a formação de públicos e a importância da sua segmentação e a identificação de públicos-alvo é destacada. Nesta, a defesa do valor artístico intrínseco é um dos argumentos mais invocados para rejeitar qualquer valorização da vertente dos públicos. A relação com a modalidade de apoio é frequentemente referida - a relação com a programação é destacada positivamente, com a criação é desvalorizada. Em qualquer caso, a possibilidade de a quantidade de espetadores poder ser um critério com influência na atribuição dos apoios é bastante mencionada para, com raras exceções, ser fortemente contestada.

Chama-se a atenção para o facto de a valorização dos públicos estar contemplada no atual modelo (o que não significa necessariamente adesão ao modo como está contemplada), refere-se especialmente a articulação entre cultura e educação e o trabalho com as comunidades, chama-se a atenção para questões territoriais e de exclusão social.

6 Independentemente dos públicos (encerrados por conceitos muito discutíveis), os projetos devem ser valorizados por critérios artísticos e de gestão - tal como já vimos, com um peso maior colocado sobre os aspetos artísticos -, quer sejam dirigidos aos públicos infantis, os públicos adultos, os públicos jovens, os públicos socialmente desfavorecidos ou quaisquer outras designações que procuremos identificar. Um projeto artístico não é mais ou menos válido por estar orientado para crianças ou idosos.

[7 - teatro, teve apoio]

G6 Penso que o modelo já o prevê (majoração de critérios de avaliação). É importante notar que estes apoios são muitas vezes fundamentais para a execução do que serão as 'actividades principais' das actividades e há uma tendência crescente para valorizar (talvez excessivamente) a formatação de actividades para públicos específicos. Mesmo sabendo que muitas das entidades estarão já sensibilizadas para a importância do desenvolvimento de projectos de formação, inclusão, etc., convém mais uma vez não perder a noção de que a valorização dessas vertentes deveria ser acompanhada pelo reforço do apoio e não pela diluição dos apoios existentes.

[419 - música, teve apoio]

6 Tanto o serviço educativo, como trabalho com as comunidades, foi fomentado pela própria DGArtes, nos critérios de apreciação dos apoios. Será importante 
ter em conta a diversidade de públicos, mas não como critério único, nem de seleção, nem de exclusão, de uma determinada atividade ou entidade.

$$
\text { [266 - teatro, teve apoio] }
$$

66 A discriminação positiva só deve sentir-se na medida em que ajude a eliminar factores de desertificação territorial ou de exclusão social. De resto somos todos cidadãos.

[365 - teatro, teve apoio]

Outros contributos suscitam leituras talvez mais específicas. Uma delas remete para a questão do número de espetadores e seu (eventual) uso como critério de atribuição do apoio. Questão que é objeto de controvérsia, mais frequentemente de sentido contrário ao seu uso, designadamente em contraposição ao desenvolvimento de públicos, temática igualmente referida quanto se trata de valorização desta vertente.

66

[...] É importante considerado como um indicador de avaliação a quantidade de público alcançada pelos projetos e, porque não, existir um valor máximo de apoio atribuído por espectador.

[57 - cruzamentos disciplinares, teve apoio]

G6 É evidente que entregar dinheiro do Estado para trabalhos que não têm público, claro que não. Mas tornar os números absolutos num critério taxativo, é prematuro, dado o estado em que nos encontramos. Que o público seja considerado... talvez sim. Mas depois de alguns anos de trabalho de base para que se crie na população que temos um público para o trabalho das artes. Até lá, é injusto.

[16 - teatro, nunca concorreu]

66 É claro que sala cheia não é sinónimo de qualidade do espetáculo, nomeadamente em espaços que não criam hábitos de consumo no espetador, de uma oferta de programação contínua e diversificada, prevendo uma estratégia a longo prazo. É, por isso, necessário compreender se o número de públicos advém efetivamente desse investimento feito pela entidade artística instalada na região onde desenvolve o seu trabalho, ou se unicamente se trata de uma afluência esporádica, em função de propostas de espetáculos ditos comerciais.

[432 - teatro, teve apoio] 
66

Deve apoiar o desenvolvimento de públicos (sua captação, qualificação e fidelização), não atendendo apenas à quantidade.

[259 - cruzamentos disciplinares, teve apoio]

66 Deve ser um importante critério de avaliação, não os números de público de per se (se bem que também estes devem ser tidos em linha de conta) mas deve ser um campo de avaliação específico. $O$ trabalho que cada estrutura concorrente a apoio faz relativamente ao desenvolvimento de públicos deve ser valorizado em candidatura na medida semelhante ao que acontece com o mérito do projeto artístico, currículos dos profissionais e outros campos que atualmente compõem o principal corpus das candidaturas. Naturalmente que numa linha de concurso a projetos de criação experimental, não faz sentido dar aos públicos a mesma relevância pontual do que em candidaturas a linhas de apoio a programação ou, como no caso que defendemos, a linhas de apoio a companhias residentes em espaços municipais.

[506 - teatro, teve apoio]

Chama-se a atenção para a importância da segmentação de públicos de modo a valorizar a sua diversidade, em articulação aliás com o desenvolvimento de públicos.

G6 Como já afirmámos, perece-nos estratégico visar os públicos jovens, onde que que eles estejam, nos centros ou nas periferias, em directo, através da net, de outras formas de edição, etc. Por exemplo, criando (o que pode ser feito afectando espaços e equipamentos existentes, mobilizando agentes locais, assim o Estado deseje e providencie os recursos) centros de artes locais.

[515 - cruzamentos disciplinares, teve apoio]

66 Os públicos que podem beneficiar desenvolvimentalmente das artes são os públicos jovens porque as capacidades desenvolvem-se a todos os níveis quando a educação contempla as artes porque estas fazem com que o desenvolvimento do ser humano seja holístico.

[149 - música, nunca concorreu]

6 [A entidade 503] considera que, o facto de uma estrutura desenvolver atividades para mais do que um público-alvo, deve ser valorizado no modelo de apoio às artes, através de majoração da pontuação nesse item de avaliação das candidaturas. Trabalhar para abranger diversos públicos-alvo exige um conhecimento e uma preocupação para com esses diferentes públicos. Para chegar a essa variedade de públicos, as estruturas são obrigadas a desenvolver atividades diversificadas. Como tal, esse conhecimento dos vários públicos aliado à 
diversidade de atividades a serem desenvolvidas para eles, deve ser claramente valorizado no modelo de apoio às artes.

[503 - teatro, teve apoio]

66 O desenvolvimento de públicos é, até de acordo com as melhores práticas distinguidas a nível europeu, um dos vetores fundamentais do trabalho dos agentes culturais e parte fundamental da equação composta pela criação artística, os criadores e os públicos. Daí considerarmos que se deve separar por tipologias de ação as estruturas a concurso público. Ninguém tem obrigação, como artista, de se dedicar particularmente, ou de todo sequer, ao desenvolvimento de públicos. Mas o Estado tem essa responsabilidade consagrada na Constituição. Por isso, os mecanismos de financiamento têm que valorizar as estruturas que abrangem públicos diversos e que têm no desenvolvimento de públicos um vetor de atividade fundamental, em igual medida que valoriza ou majora o experimentalismo ou a internacionalização, por exemplo. Não trabalhar para o público não pode nunca ser mais digno ou válido do que trabalhar privilegiada e especificamente para um, ou vários, ou todos os públicos. No limite, o mais puro experimentalismo artístico só pode existir se existirem estruturas que assegurem um trabalho de criação artística e fruição cultural orientado para o serviço público e que contemplem iniciativas e premissas de didatismo.

[506 - teatro, teve apoio]

Uma outra linha de posicionamentos remete para a importância da produção de conhecimento sobre diversas realidades do sector com chamadas de atenção para a indispensável realização de estudos e avaliações e para a utilização de metodologias qualitativas e não apenas quantitativas.

66 Outra coisa é medir e avaliar o impacto do trabalho das estruturas financiadas, factor que deve ser considerado sob perspectivas diferentes e complementares e por metodologias qualitativas e quantitativas.

[498 - teatro, teve apoio]

66 Para uma primeira candidatura a vertente do público não deveria ser considerada pela sua imprevisibilidade. Em situações futuras proponho que o público possa avaliar os espectáculos apoiados, por exemplo por meios ao dispor nas salas, exemplos, livros brancos e questionários. Também pela criação de uma plataforma de acesso público para receção de críticas no site da DGARTES.

[319 - teatro, concorreu mas nunca teve apoio] 
66 Em primeiro a DGArtes deve analisar que públicos têm menos acesso às artes. Criar um estudo que procura saber que carências artisticas existem em determinada zona do Pais e a que público especifico

[509 - teatro, concorreu mas nunca teve apoio]

Quanto aos modos de valorização desta vertente no modelo de apoio às artes (seguindo agora, como se disse, as opções de resposta consignadas na questão), a grande maioria das entidades que compõem a amostra (oito em cada dez) considera que deve ser de algum modo valorizada (gráfico 18). Observados isoladamente, o modo que reúne maior apoio é o critério de avaliação (38\%). Para além das restantes opções previamente definidas (fator de majoração em candidatura, com $28 \%$, e modalidade de apoio, com $20 \%$ ), uma em cada dez entidades prefere outra solução. Com uma frequência não despicienda, as entidades concordam simultaneamente com duas (ou mesmo três) opções (a pergunta é de resposta múltipla). Deste ponto de vista, as que combinam as opções critérios de avaliação/fator de majoração em candidatura são as que reúnem maior apoio (12\%). Por outro lado, $20 \%$ defende que a vertente dos públicos pura e simplesmente não deve ser considerada.

\section{Gráfico 18. Públicos no modelo de apoio às artes}

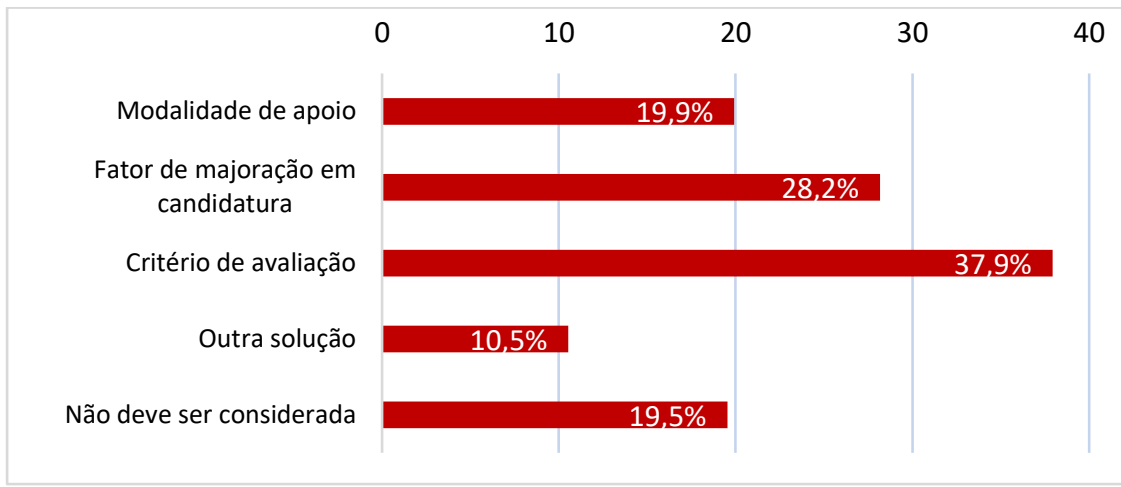

( $\mathrm{n}=522$, resposta múltipla)

Fonte: CIES-IUL, EPEA, 2017.

\section{Modalidade de apoio}

Nos contributos que assinalam esta opção, as entidades destacam a importância dos públicos, a necessidade da identificação dos públicos-alvo (por exemplo, 
por classes de idade), da segmentação dos públicos e de apoios focados em determinados tipos de públicos (crianças e famílias, por exemplo). A especificação dos públicos nos planos de atividades é um aspeto igualmente considerado.

Estes aspetos associam-se, por vezes, à necessidade de criação de condições de acolhimento. Mas pode também ser considerado no sentido da integração de diferentes públicos e de uma participação eventualmente mais ativa do que aquela mais comum de espetador. Em vários contributos, a opção pela modalidade de apoio é condicionada, por exemplo, à sua avaliação experimental. Ou, noutra perspetiva, condicionada a abarcar novos públicos. Esta opção pode também ser considerada, mas de forma a não ter consequências nas candidaturas, uma vez que o financiamento não deve ser condicionado pelos públicos - um posicionamento que distancia os apoios financeiros das considerações sobre os públicos.

66 Muitas vezes são necessárias criar as condições para receber o público, desde as actividades inerentes como a recepção, encaminhamento, etc. Por outras é necessário adquirir equipamentos ou alugar salas para receber e acomodar o público. Pensamos ainda que os públicos alvo dos eventos deveriam ser identificados nas candidaturas com referência em termos de objectivos para a criação e manutenção desses mesmos públicos.

[258 - artes plásticas, nunca concorreu]

6 Considerando o que mencionámos atrás, o apoio a planos de actividades que, no seu conjunto, demonstrem integrar diferentes públicos num contexto de participação que ultrapasse o de espectador merece ser equacionado como uma modalidade de apoio.

[270 - artes plásticas, teve apoio]

66 Como Modalidade de apoio pode ser interessante mas precisa de avaliação experimental.

[359 - artes plásticas, nunca concorreu]

66 Deveria ser criado um programa de apoio para projetos que promovam o gosto pela arte e a criação de novos públicos.

[57 - cruzamentos disciplinares, teve apoio]

66 Ou é considerada como modalidade de apoio, por forma a não haver impacto nas candidaturas que não especificam um público ou não se conformam às concepções de público vigentes; ou não deve ser considerada. A arte, e o seu 
financiamento, não devem andar a reboque de públicos, sejam estes quais forem. Se se consideram ou devem considerar públicos específicos, a criação e/ou programação direccionada a estes deve ser coberta por modalidades de apoio distintas.

[14 - fotografia, concorreu mas nunca teve apoio]

6 É necessário perceber-se que a criação de eventos tem sempre subjacente um determinado tipo de publico alvo, logo, pode ser para muitos ou poucos ou outras facetas, pelo que deve haver um apoio financeiro que permita ao publico custear a presença nos eventos.

[146 - música, teve apoio]

66 Talvez deva existir uma modalidade de apoio específico que complemente a capacidade das entidades mas esse trabalho também deverá fazer parte da avaliação e existir enquanto critério a majorar. De forma a que a natureza da entidade se possa encaixar nessa realidade.

[419 - música, teve apoio]

6 Quem, por exemplo, atua no centro da cidade e tem também uma atividade docente, o público alvo é constituídos por um público infanto-juvenil, adulto, local e estrangeiro. Se uma instituição está vocacionada para um público determinado, nesta condições deve ser valorizado, mas não ser um fator de penalização para quem atue para um público diversificado.

[451 - música, teve apoio]

66 A definição do público-alvo é essencial num projecto cultural de qualidade. Desta forma é possível a divisão do público-alvo por categorias: - infanto-juvenil - público em geral - inserção social Assim, também será possível a criação de modalidades de apoio conforme o público-alvo do projecto candidato.

[504 - música, concorreu mas nunca teve apoio]

64 Este ponto é complicado, mas talvez faça sentido criar um apoio especifico para os vários sectores etários...

[30 - outra área, nunca concorreu]

66 Como indicado anteriormente, poderá ser complicado criar uma tabela de pontuação ou indicar factores de majoração de um público específico em detrimento de outro. A melhor forma de contabilizar o público-alvo na candidatura de um projecto é criar linhas de apoio específicas para os públicos que se pretende destacar. A criação de um apoio a actividades desenvolvidas para o público infanto-juvenil, por exemplo, seria em princípio mais justo, visto o jurí ser 
constituído de forma diferente, escolhendo-se pessoas mais sensíveis a este projecto e conhecedores das necessidades deste público.

[406 - outra área, concorreu mas nunca teve apoio]

66 Esta solução adequa o apoio à missão da entidade, apoiando a pluralidade dos trabalhos artísticos.

[115 - teatro, concorreu mas nunca teve apoio]

66 Desta forma dá-se importância à vertente dos públicos (para nós é um factor crucial desde a criação da entidade e do projecto) e permite trabalhar especificamente esta vertente. No entanto, um artista que pretenda concentrar-se em apenas um tipo de público, também perfeitamente legítimo, pode fazê-lo sem ser prejudicado por isso,

[457 - teatro, teve apoio]

A articulação entre este modo de valorização dos públicos (até em detrimento de outros), o trabalho com as comunidades, a criação e formação de públicos e as políticas públicas (culturais e não culturais, centrais e locais), bem como o seu impacto do ponto de vista do financiamento são igualmente mencionados.

66 Acrescento que não deve haver majoração, é uma opção de trabalho, não é mais ou menos importante que todas as outras. O que é importante no trabaIho com as comunidades é que ele seja parte de um plano estatal de criação e formação de públicos, ou seja, que haja um desiderato nacional de levar as artes a todo o território, a todas as idades e durante todo o tempo de vida. Este objectivo só será alcançado quando o Estado, através dos seus governos, decidir impor a si mesmo essa missão, desenvolvendo uma articulação ramificada entre ministérios, administração central e local e institutos públicos.

[242 - teatro, nunca concorreu]

66 [...] talvez com esta opção [Modalidade de apoio] se possa vir a corrigir a situação de sub-financiamento crónico nos apoios à criação para as crianças e famílias

[330 - teatro, teve apoio] 
6 O apoio às artes é fundamentalmente um apoio ao público que se reflecte no acesso mais económico ou gratuito que o público tem para usufruir da obra artística. Este é o único ponto relevante.

[375 - teatro, teve apoio]

66 Tal como dissemos, a vertente dos públicos não deve ser factor de majoração, mas poderá constituir uma modalidade de apoio própria, caso se justifique em face do número de projectos que se apresentem a concurso no território

[62 - teatro, teve apoio]

66 Não nos tinha ocorrido a modalidade de apoio, mas faz todo o sentido que o seja, há estruturas que são vocacionadas para esse trabalho ou que são em parte vocacionadas para esse trabalho e devem concorrer com estruturas com um trabalho semelhante. Incluir esta vertente no concurso geral pode ser fonte de injustiças e confusões. A criação artística é uma área, a formação e trabalho específico para comunidades (ainda que falemos de criação artística também) respodne a outros critérios.

[437 - teatro, teve apoio]

\section{Majoração em candidatura}

As fundamentações para que a vertente dos públicos seja considerada como majoração em candidatura ( $28 \%$, recorde-se) destacam a importância que isso pode ter para motivar as entidades a dar maior importância aos públicos nas suas criações. Não tanto em termos quantitativos (embora também se defenda alguma relação entre apoio e quantidade de públicos), mas na sua diversidade ou na sua adequação ao projeto em causa.

6 Num pais onde nao ha a cultura de ir ao museu ou ir ao teatro ou opera, e os shopping centers sao dominantes pensamos que medir e ajudar a formar publicos é importante. No entanto nao pode ser o factor predominante senão tudo se torna um numero e esquecemos que formar publicos demora pelo menos 5 anos. Nas areas criativas torna-se dificil e dispendioso analisar publicos e especialmente em estruturas precarias. Reconhecemos a importancia de olhar para os publicos e estamos interessados em formar publicos. Como se analisa e se torna um factor de majoração penso ser mais complexo.

[208 - artes plásticas, nunca concorreu] 
66 Só manifestações culturais inovadores que gerem uma forte atração e que sejam acessíveis ao publico em geral podem trazer uma ligação entre o ensino, as artes e a cultura e fomentar o diálogo cultural.

[428 - artes plásticas, concorreu mas nunca teve apoio]

6 Dada a relevância da formação de públicos e atendendo que as entidades devam ter essa missão, pensamos ser justo que projetos com uma intervenção junto dos públicos (quer direta quer indiretamente) devam ser majoradas relativamente a entidades que não desenvolvam esse trabalho.

[269 - artes plásticas, teve apoio]

66 apoio às estruturas que se propõem realizar um plano de atividades, representa um investimento público do Ministério da Cultura que tem como destinatário final proporcionar um direito aos cidadãos (público). Neste sentido, o apoio às artes deve ter em conta a heterogeneidade dos projetos, ao nível das suas propostas estéticas e conceptuais, não podendo dissociar o apoio às estruturas do serviço público que elas irão prestar com as suas produções artísticas ou com a sua programação. $\mathrm{O}$ mesmo é dizer que, cabe às estruturas financiadas apresentar com rigor as expectativas que têm com cada uma das suas realizações, ao nível do número espectadores. Este facto não invalida e, pelo contrário salvaguarda, a natureza de cada criação ou o critério que presidiu a uma determinada opção na programação, em termos da audiência mais ou menos ampla que se deseja. Ao mesmo tempo, qualquer estrutura financiada não deverá ser penalizada por não atingir os índices de público que pretendia, cabendo-Ihe, no entanto, refletir e justificar à DgArtes as razões que levaram a que tal acontecesse. $O$ experimentalismo e a contemporaneidade são opções que nem sempre são mesuráveis pelo índice de espectadores, cabendo a cada estrutura encontrar alternativas que justifiquem o apoio pelo indispensável papel de criação de novos públicos, de experimentação favorecedora da inovação e de fomento de novas linguagens artísticas. Mas, sempre, o público!

[260 - cruzamentos disciplinares, teve apoio]

66 A vertente dos públicos, pela sua dificuldade de aferição, deve ser apenas um factor de majoração em candidaturas. O que deve prevalecer na avaliação é a relevância e qualidade absoluta do projecto apresentado e da equipa participante.

[197 - cruzamentos disciplinares, concorreu mas nunca teve apoio]

66 A ser considerada, deveria ser como fator de majoração e nunca tendo em conta o $\mathrm{n}$ o de espetadores mas a diversidade dos mesmos

[178 - teatro, nunca concorreu] 
66 Havendo acções específicas para a conquista de público e de praticantes, como os workshops que temos realizado antes dos espectáculos, achamos ser um factor majorativo...

[93 - dança, teve apoio]

66 Porque os apoios devem ser para o acesso à criação e não para os criadores.

[123 - design, concorreu mas nunca teve apoio]

6 A criação de públicos é de facto um factor muito importante no futuro das nossas artes. Não vale a pena criar se depois não é compreendido. A relação e conexão com a comunidade, com a criação de "raízes" criativas, deve ser um factor também determinante na avaliação de uma candidatura. Não basta ser espectador, tem que se criar um sentimento de pertença com o projecto ou criação, para mais tarde, entende-lo e explora-lo.

[47 - design, nunca concorreu]

6 Desde que se trate de uma diversificação dos públicos e não de uma questão quantitativa, consideramos que este elemento enriquece qualquer projecto. Há que ressalvar que há regiões francamente desfavorecidas e cujos critérios podem ser quantitativos, mas relativos à população da região onde as actividades se realizam.

[500 - música, teve apoio]

6 Porque assim as entidades começam a ter mais interesse no que o publico pretende assistir em vez de fazer projetos para si e não para a população em geral.

[21 - música, teve apoio]

6 O uso de dinheiro público deve reverter para o público.

[68-música, nunca concorreu]

64 Na sequência da resposta à anterior questão, deve ser encarada de forma mista - como factor de majoração, sem dúvida, e também como critério desde que se salvaguarde a natureza específica de alguns projectos.

[297 - música, teve apoio]

66 Como referi anteriormente, qualquer projecto, em qualquer estética, ao chegar ao publico é sempre um produto de formação de publico. Actividades de 
formação de publico fomentam a proliferação e consumo de produtos de arte e culturais.

[314 - música, concorreu mas nunca teve apoio]

G6 A resposta do público deve marcar o apoio às artes: a quem consome mais, deve dar-se mais-

$$
\text { [344 - música, nunca concorreu] }
$$

6 Como já dissemos, depende de cada projeto e dos seus objetivos. É nisso que residem as opções políticos e os modos de captação de públicos. Cada projeto deverá ter o seu público alvo. E lá voltamos à importantíssima questão dos júris multidisciplinares que não conseguem, nem podem ajuizar da validade de cada projeto se não tiverem currículos adequados a esses projetos. Não se pode querer que numa candidatura se apresente, porque o questionário assim exige, que se valoriza a captação de tal público, ou outro de índole.

[204 - música, concorreu mas nunca teve apoio]

66 Porque interessa valorizar a criação e captação de públicos no quadro das candidaturas apresentadas com estratégias adequadas a cada tipo de público

[250 - música, teve apoio]

6 Pelo atrás exposto, ou seja, os projectos que considerem essas áreas devem ser valorizados positivamente através não só de um coeficiente de valoração, mas também através de uma fórmula de compensação material.

[243 - música, teve apoio]

66 Os projectos apoiados devem ter impacto nas populações, nas comunidades, e devem ser assegurados mecanismos que levem a uma maior circulação destes. Por exemplo uma peça de teatro apoiada, deveria circular pelo país. No modelo de apoio às artes, a par de outros critérios valorativos como a qualidade, etc., deve haver preocupação com o benefício do público.

$$
\text { [41 - música, nunca concorreu] }
$$

6 Deve ser considerada como ponto de partida, mas não como critério exclusivo. Na minha opinião poderão funcionar como categorias à qual os apoios concorrem sem que seja obrigatória a existência de um público inteiramente definido. Por vezes poderão existir projectos que não têm um público alvo concreto, não querendo dizer que não sejam do interesse do público.

[121 - música, nunca concorreu] 
64 Sugiro que passa a ser um factor de majoração apenas no caso das candidaturas para apoio a programação. A relação com o público é o trabalho das estruturas intermediarias (teatros, museus, etc.) - que fazem a "passagem" entre o artista e o público. Não é a responsabilidade dos criadores.

[211 - outra área, teve apoio]

66 Pegando na resposta da questão anterior, a vertente dos públicos, (os jovens públicos, i., crianças e jovens, e as comunidades locais) devem, naturalmente, ser objecto de avaliação e de majoração. Exceptuam-se os casos em que as estruturas vocacionam o seu trabalho para esse tipo de públicos.

[461 - teatro, teve apoio]

64 Caso seja a contabilização do número de espectadores, esta deve ser apenas mais um dos factores de majoração (e não "o" factor de majoração), sob pena de desvirtuar o princípio de serviço público que deve presidir ao financiamento pelo Estado das actividades de criação e programação artística.

[498 - teatro, teve apoio]

66 É de grande responsabilidade alcançar diferentes públicos e faixas etárias através de projectos de qualidade, na apresentação e na contratação dos colaboradores e elencos. Estas preocupações devem estar reflectidas no novo modelo.

[384 - teatro, teve apoio]

6 Acreditamos que, no modelo de apoio às artes, a vertente dos públicos deve ser considerada apenas como um critério de avaliação, onde, tal como atualmente, se identifica $(\mathrm{m})$ o(s) público(s)-alvo e se descrevem estratégias para o fidelizar, bem como, para criar e manter novos públicos, visto que, a arte só existe se houver público para ela. Exceto quando se verifica o caso descrito na questão anterior, nessa situação, a vertente dos públicos deve ser considerada como fator de majoração em candidatura.

[503 - teatro, teve apoio]

6 Uma obra artística não pode ser pensada sem ter em consideração o público. Esta vertente é fundamental para diminuir o fosso existente entre as obras artísticas e o público. $O$ artista deve ter essa questão em consideração na elaboração e projecção de um projecto.

[280 - teatro, teve apoio] 
Factor de majoração e não critério de avaliação de modo a não prejudicar projectos específicos que não valorizem exclusivamente esta vertente.

$$
\text { [329 - teatro, teve apoio] }
$$

66 A avaliação pode ser feita por ordem de grandeza e por ordem de diversidade de públicos. As estruturas devem preocupar-se com o público para o qual trabalham. Haver ou não haver público (em quantidade ou diversidade) deve ser determinante.

$$
\text { [322 - teatro, nunca concorreu] }
$$

6f Sobretudo nos públicos organizados (público escolar e sénior) em articulação com serviços educação e social das Câmaras num conceito de prestação de serviço público.

$$
\text { [267 - teatro, teve apoio] }
$$

G6 A definição de um público-alvo, com uma estratégia fundamentada, é um elemento que deve ser considerado como fator de majoração nas candidaturas e,

$$
\text { [484 - teatro, teve apoio] }
$$

\section{Critério de avaliação}

Do ponto de vista daquelas entidades que consideram que a vertente dos públicos deve ser considerada como critério de avaliação (38\%, a opção que recoIhe maior adesão como antes referido), destaca-se que os apoios devem ter em conta que se trata de prestação de um serviço (ao) público. Aponta-se igualmente a necessidade de ter presente/de explicitar, de identificar qual o público-alvo nas propostas. A argumentação utilizada destaca igualmente que enquanto critério de avaliação deve ser tido em conta em função do projeto em causa e dos seus objetivos.

Outro aspeto em presença é que deve ser definido em função das dificuldades enfrentadas pelas entidades na concretização do objetivo da democratização, tendo em conta por exemplo o nível cultural das populações a que se dirigem.

Também é visível a diferenciação entre o momento em que a avaliação do critério deve incidir: prévio versus final (ou de objetivos). 
6 Deve ser um critério de avaliação para que se consiga garantir que a arte em geral chega a um publico alargado.

[102 - arquitetura, nunca concorreu]

66 O tipo de público deverá ser considerado nos critérios de avaliação, mas sempre em função do projecto, porque existem projectos que não são dirigidos, por exemplo, a um público infantil, e que não devem ver as suas candidaturas prejudicadas.

[25 - arquitetura, concorreu mas nunca teve apoio]

66 A importância que cada projeto deva dar ao seu respectivo público deve ser fruto de uma visão cuidadosa ficando assim a cargo dos avaliadores perceber se este cuidado foi tomado dentro da proposta a ser avaliada.

[219 - artes digitais, nunca concorreu]

6 parece-me fundamental que deve ser um critério de avaliação, mas nunca tendo em consideração o público como número. A formação de público não acontece num curto espaço de tempo, muito pelo contrário.

[131- artes plásticas, nunca concorreu]

66 nem todos os projetos/estruturas têm como missão (principal) fazer chegar a cultura a públicos com menos acesso. Isso não reduz a sua relevância. A questão "público" também se coloca de forma diferente nas várias artes

[357 - artes plásticas, concorreu mas nunca teve apoio]

66 Estamos a falar de dinheiro público, daquilo que nós sociedade concretizamos artisticamente. O "público" deve gozar do "produto". De alguma forma deve estar envolvido e afectado.

[292 - outras áreas, nunca concorreu]

66 Porque, hoje em dia, é fundamental que os processos criativos sejam acessíveis aos diferentes públicos (adultos, infanto-juvenil e comunidades locais) através das mais diversas ferramentas de formação/sensibilização de públicos (ensaio aberto; workshops/laboratórios de criação; conversas com artistas; experimentações de dispositivos cénicos; integração de não actores em espectáculos, etc) para que estes melhor possam compreender e usufruir da criação artística contemporânea em relação directa com os seus protagonistas.

[489 - cruzamentos disciplinares, teve apoio] 
6 Todas as pessoas têm direito a ser público. Qualquer um tem o direito de entrar num museu, assistir a um espetáculo, ler um livro, e todas as outras possibilidades culturais. A população deve ter acessível espaços culturais como teatros, museus, bibliotecas, cinemas, entre outros. Direitos que devem ser garantidos pelas políticas públicas nas diversas instâncias governamentais. $O$ agente cultural desenvolve os seus projectos com vista à sua apresentação pública. Se o público é diversificado ou homogéneo depende apenas das características intrínsecas do projecto, não lhe atribuindo qualquer majoração ou minoração.

[388 - cruzamentos disciplinares, teve apoio]

6 A fundamentação já está na resposta anterior. Deve ser considerada um critério de avaliação, mas não de majoração, porque nesse caso poderia estar a forçar uma entidade a contemplar públicos em projetos de candidatura para os quais não se sente vocacionada.

[278-cruzamentos disciplinares, teve apoio]

6 As acções e o seu impacto são mais valiosas quanto mais pessoas atingirem. 0 contágio sócio-cultural nasce deste fenómeno.

[513 - dança, concorreu mas nunca teve apoio]

6

como referido na questão anterior, acreditamos em projectos direccionados e que trabalham com e para as pessoas, projectos que trazem valor e deixam valor na comunidade em que se inserem. é necessário uma real aproximação com o público e uma definição das suas necessidades.

[346 - design, concorreu mas nunca teve apoio]

6 Depende do projecto, mas à partida deve-se avaliar a adequabilidade da elaboração do projecto e sua apresentação aos seus públicos. A estratégia de divulgação e apresentação deve ser elaborada em função do público alvo. Por outro lado, se o público é de nicho isso não deve desvalorizar a candidatura, mas antes ponderar o valor atribuído.

[203 - música, teve apoio]

6 Penso que o público é importante e deve ser tido em conta na análise de uma candidatura. Não deve ser uma "condição" para reconhecer o mérito ou não do projeto artistico até porque, em sede de candidatura, as estimativas de público, nestas condições, seriam irreais. Penso que é mais importante analisar as estratégias de cativação de público do que o número deste.

[42 - música, teve apoio] 
66 A vertente deve ser considerada na avaliação já que é determinante quer para a disseminação quer para o impacto sustentável do projecto.

[111 - música, teve apoio]

66 Imagine-se um concerto por uma banda filarmónica: há um público específico que é a familia (os pais, os irmãos, os tios, os primos, os avós, o galo, o papagaio,.....): Imagine-se um concerto numa praça rodeada de cafés. Os públicos são: os que estão sentados nas mesas da esplanada, os cães que os donos levam a passear.... A questão dos públicos tem muito que se Ihe diga. Portugal precisa de programas direcionados para a formação de públicos. E a formação de públicos não passa necessariamente pela quantidade. Deveremos dar a meIhor atenção possível aos projetos que visam a formação de públicos em contextos específicos. As ações culturais para a formação de públicos deve privilegiar a regularidade junto do mesmo público durante o tempo para conquistar e ensinar a aprender a gostar.

[218 - música, teve apoio]

6 Pensamos que a vertente publico deva ser apenas um dos critérios de avaliação, em vez de a majorar ou determinar, pois o acto artistico e a sua envolvente vão mais longe e atingem mais longe que o publico direto que o vê ou aprecia.

[89 - música, concorreu mas nunca teve apoio]

6 A questão dos públicos é um critério como qualquer outro, a meu ver.

[312 - música, concorreu mas nunca teve apoio]

66 Foi respondido em Q31. Mas sempre acrescentamos que a valorização deste factor deve ser identificada e enquadrada no historial da estrutura.

[427 - teatro, teve apoio]

6 O trabalho de formação de públicos e de mediação cultural terá que ser um critério de avaliação e de majoração. Cremos que começa a haver um fosso entre quem faz e quem vê.

[286 - teatro, teve apoio]

66 A capacidade financeira de cada entidade deve ser tida em conta na questão dos públicos. Uma entidade com um apoio volumoso tem de ser avaliada na questão dos públicos de forma diferente de uma entidade com um apoio significativamente menor.

[247 - teatro, teve apoio] 
6 Deve ser considerada apenas como mais um critério no sentido de definir o tipo de trabalho de que se trata, e não como factor de majoração (não vejo como) e não como modalidade de apoio - uma peça de teatro para a infância é uma peça de teatro mesmo sendo para a infância.

[263 - teatro, concorreu mas nunca teve apoio]

66 A arte é para ser criada a partir de impulsos do artista. a partir do momento em que se subverte esta ordem inverte-se o sentido próprio da criação. É importante a atenção aos públicos mas não devemos dar-Ihe demasiado valor. Daí ser ponderado um critério mais de avaliação.

[274 - teatro, teve apoio]

6 Cada espectáculo/actividade deve cumprir a sua meta estabelecida de alcance de públicos.

[438 - teatro, teve apoio]

G6 É natural que o público deva ser tido em conta na avaliação, mas não pode ser um critério decisivo num país em que a luta de formação e fidelização de públicos é de todos e em que os números não correspondem directamente à qualidade e à relevância dos projectos. Trata-se de melhorar a relação com o mercado, não fazer dele o principal valor. Para isso não talvez não fosse preciso MC.

[499 - teatro, teve apoio]

66 A vertente dos públicos pode ser tida como critério de avaliação na medida em que se considera que os projectos devem apresentar de forma global alguma consciência do contexto em que se propõem trabalhar.

[530 - teatro, teve apoio]

66 Considerando que são financiamentos públicos, os projetos devem considerar a importância do público para facilitar uma maior fruição cultural no País.

[238 - teatro, concorreu mas nunca teve apoio]

64 A vertente dos públicos deve ser considerada como critério de avaliação mas não de uma forma meramente quantitativa e determinante. Ou seja, há que avaliar sempre o número de espectadores de cada criação, mas numa relação equilibrada com o interesse cultural da proposta e a sua exigência artística. 
Não se pode comparar ou colocar em pé de igualdade espetáculos de repertórios teatrais específicos e espetáculos mais lúdicos e assumidamente de entretenimento.

[264 - teatro, teve apoio]

64

Deve ser critério de avaliação não em termos quantitativos mas sim em termos de qualidade do público. Porque é que o Estado apoia as artes? Porque quer que a produção cultural e artística chegue às pessoas por um lado, e que a cultura portuguesa per se se desenvolva e se expanda. Assim é necessário ir ao encontro de público diferenciado com o objetivo assumido de dar a conhecer diferentes propostas artísticas a públicos também eles diferentes.

[279 - teatro, teve apoio]

6 Na avaliação destes critérios devem ser considerados o nível cultural das populações, o seu relacionamento com os bens culturais e os hábitos de fruição cultural. Os apoios devem considerar as dificuldades de mobilização dos públicos no sentido da democratização da cultura.

[283 - teatro, teve apoio]

66 A vertente dos públicos, será um critério como qualquer outro, como exemplo poderá ser semelhante à tipologia de atividade. A vertente dos públicos não pode ter a mesma importância, de um autor ou qualquer outro criador.

[266 - teatro, teve apoio]

6 No nosso entendimento o nosso trabalho entende -se no cumprimento de um serviço público. é para e com o público que trabalhamos. No nosso entendimento pode ser avaliado o projeto artístico também pela diversidade de públicos que as entidades pretendem envolver nas suas actividades, o trabalho com as escolas, para a escolas, com as comunidades, com populações por algum motivo fragilizadas, no entanto esta avaliação sempre na perspectividade do projeto a realizar, de que forma terá impacto nesse público participante.

[281 - teatro, teve apoio]

6 Uma vez que um dos principais objetivos dos apoios às artes é a descentralização e a correção de assimetrias regionais. Devem-se valorizar projetos que fomentem verdadeiramente a descentralização cultural e não apenas obedecer a uma fórmula cega de majoração, tal como acontece nos apoios pontuais, onde acaba por ser indiferente a atribuição de majoração a um projeto que circula em 2 ou 10 localidades. A atribuição da avaliação deveria ser de 0 a 10, sendo que 10 seria obrigatoriamente para projetos que passassem por todas 
as grandes regiões definidas pela DGArtes (Norte, Centro, LVT, Alentejo e Algarve).

[502 - teatro, concorreu mas nunca teve apoio]

66 A diversidade dos públicos é interessante mas, mais importante, é a localização dos mesmos. Trabalhar para públicos vastos - cidades - ou estabilizadamente para públicos em locais pequenos e mais empobrecidos - vilas e aldeias do interior - é totalmente diferente de fazer teatro itinerante. Ao fixarmos um espetáculo num local destes últimos, fomentamos o turismo interno (no nosso caso até temos acordos com o comercio local). Isto tem sido desvalorizado nas nossa candidaturas.

[483 - teatro, concorreu mas nunca teve apoio]

6

Deve ser um dos critérios de avaliação, mas não deve ser taxativo, porque nem todas as estruturas obviamente trabalham para grandes públicos. Mais uma vez tem de ser tida em consideração a actividade principal e o perfil da entidade em causa.

[527 - teatro, teve apoio]

6 Dependendo do público alvo a proposta deve ser considerada de forma a que a Arte seja menos elitista e mais para todos e por todos

$$
\text { [4 - teatro, concorreu mas nunca teve apoio] }
$$

\section{Não considerar}

Os posicionamentos agrupados em torno da opção que desvaloriza a possibilidade de esta vertente dos públicos ser considerada no modelo de apoio financeiro às artes (22\%) corresponde à (hiper)valorização da qualidade artística do projeto como único critério que deverá ser tido em conta, uma vez que os públicos não podem ser o fator relevante para decidir se o apoio deve ou não ser concedido.

6 A preocupação deve incidir na qualidade e não na quantidade.

[207 - artes plásticas, teve apoio]

G6 Como disse antes, o público está distante da pratica. Se uma candidatura pretende a produção de um projecto e não envolve directamente um público, esse 
público não interfere nem deve interferir na decisão do júri. $\underline{\text { O público virá de- }}$ pois, ver o resultado desse apoio. Simples.

[411 - artes plásticas, teve apoio]

66 Não deve ser considerada em projectos de criação artística, sendo importante desvincular esta vertente da qualidade do projecto. Poderia apenas ser considerado como critério de avaliação para contextos e estruturas em que esta vertente seja já assumida de forma programática.

[490 - artes plásticas, teve apoio]

G6 O público é subjetivo. A programação ou criação artística não pode depender de públicos. Isso deve ser uma consequência.

[124 - artes plásticas, nunca concorreu]

6 O critério deverá ser a qualidade das propostas.

[199 - artes plásticas, nunca concorreu]

66 É importante distinguir arte e entretenimento, embora haja intersecções, naturalmente. Acrescento ainda que se um evento tem muito público tem também capacidade de se auto-financiar, contrariamente ao que sucede com eventos de carácter "experimental".

[83 - cruzamentos disciplinares, teve apoio]

6 Os publicos-alvo, em alguns casos são uma hipotética sugestão\idealização. Nem sempre o idealizado é fielmente concretizado. O conceito, modos de concretização e como é planeada a divulgação são mais importantes

[183 - cruzamentos disciplinares, teve apoio]

66 O projecto deve ser avaliado em si mesmo na sua consistência e qualidade. A formação de públicos decorre de uma dinâmica da oferta cultural lata que em si mesma decorre de uma convergência de trabalho continuado entre o estado central, autarquias, freguesias, escolas, estruturas independentes e artistas.

[244 - cruzamentos disciplinares, teve apoio]

6 Por princípio não deve ser considerado. Caso se trate de programação, sim. A constituição de património não deverá depender das contingências de um público.

[351 - cruzamentos disciplinares, teve apoio] 
66 Será a parte que mais desonestidade possui nos modelos de candidaturas. A realidade é bem diferente do que se escreve nesses campos.

[328 - cruzamentos disciplinares, teve apoio]

66 Há obras que apesar não terem grande percentagem de publico são obras primas.

[501 - dança, nunca concorreu]

66 Não poderá ser avaliado o publico-alvo de um projecto em comparação com outro, nem o numero de publico de cada projecto em perspectiva. Cada projecto depende sempre do seu contexto de apresentação e não é valorizavel nesses termos.

[523 - dança, nunca concorreu]

6 Acho que num emergente a situação de numeração dos públicos é irrelevante.

[26 - dança, concorreu mas nunca teve apoio]

6 Acho que não deve ser um critério de avaliação. Penso que o foco deverá estar nas propostas específicas do que se pretende fazer. A distinção de públicos pode ser uma forma de perceber as necessidades sociais e culturais (se há poucos projectos para adultos talvez se pudessem abrir concursos direccionados) no entanto a qualidade é sempre mais importante do que a quantidade.

[171 - design, concorreu mas nunca teve apoio]

66 Os apoios devem ter em conta a relevância artística do projecto, independentemente do público alvo, devem promover a diversidade e não restringir o pensamento artístico tendo em conta o público.

[28 - música, teve apoio]

66 Criar majorações para públicos infantis ou escolares pode ser um factor de injustiça. Nem todas as obras são adequadas para públicos específicos.

[79 - música, teve apoio]

66 A vertente dos públicos é importante, mas não pode ser o fator relevante para decidir o não o apoio a conceder.

[106 - música, teve apoio] 
66 Tornar a vertente "publico" enquanto modalidade passível de avaliação, majoração, apoio ou outra coisa qualquer é para nós uma truque para se demitir duma programação de qualidade e por á frente alguns factores "exóticos" que servem para maquilhar o âmbito cultural mas que não serve á principal missão cultural.

[296 - música, teve apoio]

66 Não se poderá valorizar o "grande público" em detrimento do "pequeno público" Há eventos naturalmente de milhares de pessoas e outros de apenas dezenas É particularmente injusto este paralelo em considerações "elitistas" das diferentes artes e estéticas

[349 - música, teve apoio]

6 O apoio público deve ser para projectos vanguardistas. Se existe falta de conteúdo no mercado para um determinado público a indústria é melhor a criar a solução para o problema. Se existe mercado para o teatro para idosos, então existe potencial para criar uma empresa, com ou sem fins lucrativos para responder a esta necessidade. Os estímulos neste caso eliminam a iniciativa privada, e quando desaparecem, aparece uma carência de conteúdo.

$$
\text { [185 - outra área, nunca concorreu] }
$$

66 A vertente dos públicos não deve ser considerada como factor de majoração ou como critério de avaliação na atribuição de apoios, pelo menos em todas as áreas artísticas. Se nalgumas delas pode fazer sentido - sempre relativo porque quantidade de público não é, de todo, sinónimo de qualidade de projecto -, outras há em que dificilmente se aplica, como é o caso dos apoios à Investigação Artística, cuja criação defendemos, que dificilmente se verão reflectidos em públicos.

[487 - outra área, teve apoio]

66 Quando fazemos uma actividade de carácter público não devemos limitar à partida quem será o nosso alvo porque como são actividades públicas não sabemos quem vai usufruir directamente. Podemos deduzir e por isso apenas podemos relatar o nosso desejo nas candidaturas.

[307 - teatro, teve apoio]

66 Não é a caraterística do público que torna um espetáculo adequado a esse público nem determina o seu sucesso. A regionalização tem de ser majorada de outras formas e os espetáculos infantis deveriam ter um concurso à parte.

[460 - teatro, concorreu mas nunca teve apoio] 
66 Não acreditamos que a separação ou valorização destes vários públicos aquando da análise das candidaturas seja um caminho verdadeiramente desejável. Na nossa perspetiva, tais medidas promoveriam a clivagem e abririam espaço para uma segmentação de públicos muito pouco útil.

[7 - teatro, teve apoio]

6 Achamos que deve ser valorizado o projecto artístico em si e a sua consistência e não em função da diversidade de públicos a que se destina.

[291 - teatro, teve apoio]

66 A valorização de quantidade/qualidade de publico pode resultar na diminuição da qualidade artística dos projectos, numa tentativa de agradar. Cada grupo tem as suas especificidades e deve ser mediante estas que se deve fazer uma avaliação.

[90 - teatro, teve apoio]

66 Não o pode, pela nossa experiência, em digressão com as nossas criações pelos diferentes concelhos da Ilha da Madeira, já tivemos salas com 6 espectadores e outras com 200. Quando fazemos algo para seis espectadores pode esse momento ser mais importante que termo-lo feito para mais de 200.

[2 - teatro, nunca concorreu]

\section{Outras soluções}

As fundamentações expressas pelas entidades que assinalaram esta opção de resposta (11\%) sugerem, como principal padrão identificável, que não se trata propriamente de apontar outras soluções para além das consideradas na questão, mas sim de outra(s) forma(s) de dizer que a vertente dos públicos não deve ser considerada. Ou que poderá ser considerada, mas em condições muitos específicas: pelo projeto em causa; pela área/atividade; pelo concurso; pelo domínio, ou seja, no domínio da criação esta vertente é claramente desvalorizada. Uma outra linha de posicionamentos chama a atenção para que a consideração, ou não, e em que moldes da vertente dos públicos deverá decorrer das políticas públicas e suas orientações.

Ainda assim é possível identificar posicionamentos que permitem considerar algumas especificidades relevantes do ponto de vista do modelo. Um dos argumentos é que poderá ser valorizada em função da mediação nos processos de aproximação aos públicos, sobretudo em contextos sociais desfavorecidos. 
Outro refere-se aos júris: importará que estes tenham acesso aos dados de públicos; e devem integrar competências em mediação e programação.

66

O centro da avaliação tem que ser o mérito artístico dos projectos. Nos projectos de criação a questão do público pode julgar um papel muito modesto ou tendencialmente nulo. Nos projectos de programação já é relevante a verificação do acerto entre o que se propõe e a existência de públicos. Importa recentrar os concursos de "apoio às artes" na vertente de criação, desidentificandoos da ideia de que são concursos de "apoio à fruição cultural por parte de publico". Podem incluir a componente de difusão, educativa, interpretava, formativa, mas não é essa a sua vocação principal. Enquanto se confundirem os planos não teremos produção qualificada para difundir, seja internacionalmente seja junto do público.

[299 - arquitetura, concorreu mas nunca teve apoio]

66 Nas atividades de programação, deve ser considerada e avaliada a coerência dos públicos alvo definidos em candidatura relativamente aos projetos propostos. Nas atividades de criação não deve ser sequer considerada, a não ser que explicitamente definida pelo candidato como sendo elemento relevante.

[11 - artes plásticas, nunca concorreu]

6 As questões relativas às audiências são complexas, no contexto das práticas artísticas contemporâneas, e não devem de ser critério de avaliação. A própria ideia de público é complexa (online, no espaço, o leitor). A qualidade dos projetos não se relaciona, portanto, diretamente com a quantidade ou diversidade do público.

[86 - cruzamentos disciplinares, concorreu mas nunca teve apoio]

6 A avaliação não deve ser feita a pensar nos números de público final, pois se pensarmos por exemplo em quantos bilhetes foram vendidos, tendencialmente irá ser valorizado a casa que acolher mais público. Mas esta é também a casa que deveria conseguir trabalhar a sua autonomia económica com uma equipa de gestão que procurasse novos financiadores. A par do gestor, o que deve ser valorizado é o trabalho do mediador que implementa o processo de aproximação ao público. Uma peça numa vila rural que tenha público, está a gerar uma nova oportunidade para artistas que normalmente não estão nas grandes salas de espetáculo e que tendencialmente conseguem "encher a casa".

[92 - cruzamentos disciplinares, concorreu mas nunca teve apoio] 
6 Acho que tem sentido para estruturas, teatros, festivais, exposições, que são entidades que tem a responsabilidade de criar público e deversificar o seu público. Mas não tem muito sentido ser avaliado da mesma forma numa candidatura de criação.

[257 - dança, teve apoio]

66 Consideramos mais pertinente e séria a inclusão obrigatória em todos os júris de um especialista nas áreas da mediação e da programação para públicos não especializado/ em formação, que possa identificar a adequação das propostas candidatas e reconhecer os artistas que desenvolvem trabalho nesta área. No caso das entidades que fazem programação, inversamente, a existência de ações adequadas de mediação e a diversidade de destinatários contemplada nas programações devem ser tidas em consideração nos critérios de avaliação. Por último, no que diz respeito à correção de desigualdades territoriais, e portanto a territórios onde deste ponto de vista haja resposta insuficiente, devem ser valorizados projectos que possam trazer grande qualidade à oferta local/ regional.

[376 - dança, teve apoio]

6

Esta é uma área difícil. Como estrutura defendemos a importância do publico neste tipo de projectos. $O$ publico tem de ser levado em conta e se um projecto não consegue publico não faz sentido. Sabemos bem que os meios de comunicação nos últimos amos criam públicos para o que lhes interessa e que são estes os recordistas de audiências, podendo não ser os mais relevantes para o País ou para os territórios. Pelo que quantificar o publico é embarcar no imediato e a cultura de um país não é isso, isso são modas, tendências vendas! Por outro lado nas regiões do interior o publico não pode ser quantificado da mesma forma, pois mesmo que os números sejam baixos eles podem equivaler em termo do território em muito mais gente que num espaço do litoral. Ainda teremos de ter em conta que podemos estar a cometer injustiças quantificando esses números, por exemplo se uma estrutura está instalada num espaço municipal onde a própria câmara programa outras áreas os números de publico dessa estrutura não são reais. São os numero de toda a actividade desenvolvida no espaço, criando a ilusão de que aquela estrutura tem um numero de publico maior do que efectivamente tem. Isto pode dar, em comparação com outra que desenvolve as suas actividade num espaço que só ela usa, um e erro criara uma injustiça irreparável. Por isso defendemos que os números do publico sejam informativos e sirvam para que o júri analise melhor depois os orçamentos, onde achamos que o numero das bilheteiras deve ser considerado e este sim será sempre real, já que ninguém dá o valor da sua bilheteira a ninguém.

[52 - música, nunca concorreu] 
66 Apesar de importante, consideramos que a vertente dos públicos não deverá sobrepor-se a outros critérios de avaliação e fatores de majoração mais relevantes, como por exemplo a qualidade artística do projecto e dos intervenientes e a descentralização.

[109 - música, teve apoio]

6 Sem ser possível deixar de trabalhar para alcançar público, esta necessidade não pode limitar a natureza conceptual de uma criação artística. Por outro lado, se falamos em diversificar públicos, existem possibilidades de trabalho que funcionam com número controlado de público. Por fim, a quantificação linear de públicos como critério de avaliação ou majoração cria situações injustas entre entidades com capacidades de recepção muito diversas.

[407 - música, teve apoio]

64 As entidades que trabalham em locais onde o número de população é muito reduzido, não devem ser lesadas nem beneficiadas em relação às que operam nas grandes cidades, pois a capacidade de captação de públicos, varia de acordo com diversos factores que devem ser tidos em conta. Mas deve-se valorizar o trabalho de criação de novos públicos, mesmo que numericamente não sejam muito significativos, mas de acordo com as características dos projectos artísticos e do território. A qualidade de usufruto das actividades e o seu impacto a longo prazo e a nível individual, deve ser valorizado. Nem sempre uma cultura de "massas" é sinónimo de uma cultura com impacto efectivo no futuro.

[414 - teatro, teve apoio]

6 Os números nem sempre traduzem a importância dos projectos. Só uma avaliação qualitativa cuidada poderá revelar a importância que uma entidade tem para a comunidade em que se insere. De outro modo, corre-se o risco de financiar apenas entidades que se prestem a servir propósitos populistas, o que, no nosso entender, prejudicará de forma inevitável a qualidade dos projectos e a sua importância a longo prazo.

[528 - teatro, concorreu mas nunca teve apoio]

66 Todas as regras deste género conduzem a uma normalização dos projectos, indesejável de todos os pontos de vista. os públicos, na sua quantidade e na intensidade da sua relação com os objectos criados, são uma consequência da qualidade e da persistência o trabalho desenvolvido. 0 pressuposto que está por trás da questão é pernicioso.

[505 - teatro, concorreu mas nunca teve apoio.] 


\section{Questões laborais}

Relativamente às questões laborais, procurou-se recolher contributos acerca da relação do Modelo de Apoio às Artes com a questão da precariedade e situação laboral no sector, a partir de uma formulação aberta ${ }^{47}$. No âmbito do estudo, esta é uma das temáticas que suscita maior diversidade de posicionamentos e de propostas. De modo geral, os posicionamentos identificam a precariedade como uma questão complexa e mais abrangente, que ultrapassa em muitos aspetos o âmbito do Modelo de Apoio às Artes. A maioria dos posicionamentos vai no sentido de contribuir com propostas para dar resposta à precariedade no sector.

A análise das respostas mostra que uma parte significativa das entidades defende uma maior regulação da questão laboral por parte do Estado. Em articulação com esta ideia propõe-se igualmente que o Ministério da Cultura e a DGArtes assumam um papel mais interventivo a este respeito.

\section{Propostas no âmbito do Modelo de Apoio às Artes}

Entre os posicionamentos que consideram este aspeto como relevante no âmbito do Modelo de Apoio às Artes, a questão laboral e da precariedade surge principalmente associada à questão da estabilidade do financiamento disponível e do orçamento global do sector.

Uma proposta muito presente, já anteriormente incluída na questão relativa às despesas a considerar nos apoios, é a do alargamento no novo modelo dos apoios à estrutura. O alargamento do período de duração dos apoios é outra solução mencionada.

Um conjunto de entidades avança como proposta a modalidade de contratação ser tida em conta como critério de avaliação ou fator de majoração das candidaturas. A este respeito, sugerem por exemplo majoração das candidaturas que prevejam boas práticas de contratação e profissionalização da equipa. Os descontos obrigatórios para a Segurança Social são outra proposta presente em muitos posicionamentos.

\footnotetext{
47 Q33. As questões da precariedade vêm ganhando maior eco nas políticas públicas. De acordo com a experiência da entidade, que mecanismos poderiam ser criados, no quadro do apoio às artes, para assegurar soluções adequadas? A taxa de resposta a esta questão é $74 \%$.
} 
O volume de trabalho não remunerado por parte dos profissionais do sector é de resto uma questão levantada por diversas entidades. A este respeito propõe-se que todas as modalidades de apoio contemplem o pagamento do trabalho dos profissionais (por exemplo, os apoios à internacionalização, no quadro atual, não preveem). O papel do voluntariado no âmbito dos projetos é outro âmbito que recolhe diversas preocupações.

Outros posicionamentos defendem a criação de mecanismos de avaliação para garantir que os profissionais envolvidos nos projetos apoiados não se encontram numa situação precária (refere-se a este respeito o papel das comissões de avaliação).

Pontualmente propõem-se ainda modalidades de apoio à contratação de recursos humanos (por concurso), ou estabelecer um financiamento mínimo às entidades para garantir a estabilidade dos vínculos.

As discrepâncias salariais dentro das mesmas funções e as acentuadas diferenças de pagamento de serviços dentro do sector também recolhem alguns contributos. Defende-se a criação de tabelas de remuneração para perfis, atividades ou tarefas específicas.

Outros contributos mais avulsos que se consideram ter um contributo positivo no âmbito laboral são: assegurar que os projetos apoiados tenham circulação nacional, assegurar uma rede de teatros com programação regular e reforçar os apoios à criação de públicos. Ainda, o apoio a residências artísticas e o apoio específico para a criação de espaços de trabalho: identificar potenciais espaços (por exemplo, espaços devolutos e outros equipamentos). O reforço dos mecanismos de apoio aos artistas emergentes, designadamente como fator de majoração, é outra proposta avançada.

Ainda no âmbito do MAA, uma parte significativa dos posicionamentos identificam o cumprimento dos calendários e dos prazos de pagamentos como dois aspetos centrais na situação laboral dos profissionais do sector. Defendem a estabilidade nos concursos, o cumprimento dos calendários e o pagamento das verbas atempadamente (minimizar os períodos sem financiamento, onde as entidades ficam numa situação de grande fragilidade e constrangimento financeiro).

G6 Antes de mais, na medida em que atribui financiamento público, a dgartes deve ser responsável por garantir que não existem situações de precariedade e incumprimento face aos direitos laborais dos trabalhadores das entidades que financia; na mesma medida, ao atribuir financiamento, deve garantir que está afectivamente a dotar as entidades artísticas de financiamento suficiente para fazer face ao pagamento de salários, e respectivos impostos, bem como 
prever mecanismos de atribuição atempada de apoios plurianuais que permitam a contratação das equipas.

Esta questão relaciona-se com uma questão anterior acerca do financiamento das despesas 'estruturais'. A verdade é que há hoje, em demasiados programas de financiamento, uma hipervalorização das despesas com 'a actividade', a 'comunicação', a ' avaliação' ou a 'disseminação de resultados', e uma relutância em financiar os custos com recursos humanos, os chamados 'custos estruturais', sejam os que respeitam aos próprios criadores, sejam os que têm que ver com todos os outros trabalhadores especializados que viabilizam e suportam os processos de criação, apresentação, difusão, mediação... É para todos evidente com certeza que, no campo artístico, se trabalha desde o ponto da formulação da ideia até à apresentação e para lá disso, com relatórios e avaliações. Nesse sentido, a actividade artística e cultural não difere muito da investigação científica (ambas dependem fundamentalmente de tempo de pesquisa e experimentação!). Isto parece óbvio, mas há demasiados programas que ignoram que, durante o processo criativo, a vida dos artistas e agentes culturais não fica suspensa, numa espécie de vácuo bondoso, em que a prestação da casa deixa de ser debitada, ou a mensalidade do infantário, ou quaisquer que sejam os custos de uma vida normal. Não somos capazes de entender esta dificuldade em financiar o trabalho.

[464 - teatro, teve apoio]

66 A valorização, em sede de candidaturas, do combate à precariedade deve ser equacionada. Quer seja por programas específicos de apoio à contratação - o ideal - quer seja pela majoração dessas questões nos concursos - proposta bem mais modesta mas que pode dar alguns resultados. A maioria das estruturas não tem capacidade para, sozinhas, combaterem a precariedade dada a suborçamentação do sector.

[276 - teatro, teve apoio]

6

Para resolver ou pelo menos aliviar a questão da precariedade, é imprescindível que os concursos considerem os custos de manutenção das estruturas a quatro anos. (...) Cada candidatura deve contemplar em orçamento os custos que a estrutura tem para funcionar e manter uma equipa a trabalhar durante quatro anos de forma ininterrupta. No caso da [entidade] muitos dos colaboradores e técnicos são contratados pontualmente, por projeto, e não de uma forma permanente, encontrando-se numa situação de precariedade. Mas se os valores do orçamento para a estrutura forem considerados, isso permitenos celebrar contratos a quatro anos, resolvendo-se esta questão. Na proposta orçamental a concurso das estruturas, o número de pessoas a contrato deveria ser um fator de majoração.

[264 - teatro, teve apoio]

6 A precariedade, no nosso caso, é o resultado de em cada concurso, o montante solicitado a dgartes não poder exceder uma percentagem do orçamento total 
proposto. Como o nosso orçamento é baixo, devido aos custos baixos das produções que apresentamos, o montante disponível para os custos com a estrutura (vencimentos incluídos) não é suficiente para evitar a nossa precariedade. Criar um mecanismo que desse conta desta especificidade, permitindo aumentar os custos estruturais com vencimentos (e mais nada), sem que a candidatura fosse penalizada por isso seria uma boa forma de a dgartes começar a lidar com a precariedade.

[139 - artes plásticas, teve apoio]

66 Todo o sector das artes em Portugal é altamente precário. No que diz respeito à nossa entidade, não existe qualquer profissional que tenha condições para ter um contrato de trabalho com a mesma, todos trabalhando a recibos verdes e sem condições de se dedicarem única e exclusivamente ao trabalho na estrutura. Isto é altamente preocupante e a partir do momento em que isto se verifica nada mais se pode assumir como razoável. Será fundamental que o apoio às artes ofereça às estruturas condições de desenvolver um trabalho profissional digno e com condições. No nosso entender, deve ser preocupação e prioridade da DGArtes garantir às estruturas e aos profissionais das artes condições de exercerem o seu trabalho de forma digna, estruturada e regular. Isto só se consegue através de um maior investimento financeiro no sector. A criação de uma linha específica para o funcionamento regular das estruturas (para além das suas actividades) parece-nos urgente e essencial.

[10 - teatro, teve apoio]

66 A emissão atempada de uma calendarização efectiva para as entidades beneficiárias seria já uma base de partida interessante. (...) os calendários de abertura de concursos deveriam ter em conta a dinâmica do sector, corrigindo-se o facto de que abram apenas na recta final de cada ano civil; desta forma, obrigam-se os recursos humanos das estruturas a passar por períodos de enorme precariedade durante os primeiros meses do ano seguinte.

[376 - dança, teve apoio]

66 As entidades apoiadas devem cumprir a legislação laboral como todas as outras entidades, considerando a especificidade e natureza das actividades artísticas, contemplada na lei 4/2008 (que deve ser melhorada). Devia ainda ser criada uma tabela de remunerações que pudesse ser aplicada por todas as entidades. por exemplo: pagamento por espectáculo; pagamento por hora de formação, etc.

[459 - teatro, teve apoio]

6 A questão da precariedade deve ser considerada como relevante na apreciação das candidaturas. A previsibilidade da realização das atividades, deveriam con- 
templar a realização de contratos de trabalhos. Com maiores certezas de financiamento, as estruturas podem crescer, contratar mais, dar mais condições de trabalho.

[238 - teatro, concorreu mas nunca teve apoio]

6

Não pode ser concebível que uma estrutura que concorre a financiamento do Estado para fazer arte, não tenha a situação dos seus colaboradores comprovadamente legal e condigna. Deve ser tão fundamental como a declaração de não-dívida à Segurança Social. Porque não solicitar a emissão de uma declaração por parte da Autoridade para as Condições do Trabalho como pré-requisito para admissão aos concursos de apoio. Passe-se a imodéstia, se nós conseguimos sem apoio, todos conseguem. Basta querer. Mas para ajudar na conjugação destas "vontades", tem o Estado que assumir aqui um papel de inequívoca regulação do setor.

[506 - teatro, teve apoio]

66 O primeiro mecanismo a assegurar seria a não derrapagem na assinatura dos contatos no início do ano, e consequentemente transferência de verbas. Para estruturas pequenas como a nossa entidade tem sido muito difícil atravessar o primeiro semestre de cada ano. Ano após ano repete-se consecutivamente o mesmo problema. Os contratos e adendas têm sido assinados tardiamente, normalmente entre Abril e Junho do ano objeto de contrato. $O$ processo de candidatura e seleção deveria estar concluído de forma a permitir que os contratos e adendas fossem assinados em dezembro anterior. Com as atuais condições poderiam ser mudado o agendamento da tranches, responsabilizando os municípios da primeira parte do ano pela maior agilidade que conseguem ter em relação ao poder central. Outra alternativa seria a existência de protocolo entre DGA e a banca no sentido de poder se adiantado parte de valor correspondente a ser devolvido à data da transferência da DGA e sem juros, ou com o valor do juros cobertos pela DGA. Esta situação já obriga entidades a proceder à suspensão de pagamento de salários e consequentemente suspensão dos contratos de trabalho, gerando uma situação de incerteza e instabilidade. Em muitos casos os dirigentes associativos também desempenham contratos de trabalho com as entidades sendo-lhes negado o acesso a subsídio de desemprego durante esses meses negros. Esta situação é causada pela leitura subjetiva da lei feita entre os diversos balcões da SS, pela deficiente e contraditória legislação vigente. Outra consequência é a distribuição das atividades ao longo do ano. Na nossa entidade por sabermos que esta situação acontece acabamos por concentrar a nossa atividade (financiada pela DGArtes) praticamente no segundo semestre do ano, o que muitas vezes se traduz num maior esforço dos recursos humanos e que pode comprometer a qualidade da execução.

[154 - outra área, teve apoio] 
6 Soluções concertadas entre as políticas de promoção de emprego e a DGARTES. A actividade artística é uma das actividades mais eficientes a redistribuir financiamentos através da compra de serviços. É uma área que deve ser priorizada. Também se deveria ter em conta a necessidade de mobilidade característica das profissões artísticas e construir um modelo que evite a precaridade mas permita a mobilidade. Os desafios são interessantes e podem funcionar como laboratório de experimentação de novas políticas de emprego. Uma vez mais a questão irá depender inteiramente dos patamares e condições de financiamento. As entidades com orçamentos de financiamento elevados deveriam ser motivadas a criar maior estabilidade dos vínculos de trabalho das suas equipas.

[49 - outra área, teve apoio]

\section{Propostas fora do Modelo de Apoio às Artes}

Avançam ainda com um conjunto de propostas fora do quadro do MAA, como a adoção de uma legislação que preveja a proteção social no desemprego e no período entre contratos (a partir, por exemplo, do modelo francês dos intermitentes ou outros a nível europeu).

6 A precariedade no setor cultural traz prejuízos a médio e longo prazo para os agentes e para o País. Uma medida pertinente seria a melhoria da legislação relativa à proteção social no desemprego, introduzindo um modelo semeIhante ao existente noutros países (por exemplo França).

[11 - artes plásticas, nunca concorreu]

Um conjunto alargado de contributos defende uma revisão do regime fiscal para o sector e o alargamento dos benefícios fiscais (tais como subir o teto da isenção de IVA, redução da carga fiscal na aquisição de bens para fins culturais).

Outro aspeto salientado é a relevância da criação de um estatuto dos profissionais do sector.

6f É urgente criar um Estatuto de Carreira para os artistas e técnicos das artes do espetáculo, valorizando-se a formação académica e a experiência profissional. Apenas depois desta organização de base será possível criar um regime de Segurança Social específico para assegurar a proteção destes profissionais.

[484 - teatro, teve apoio] 
6 Definição do estatuto profissional, definição do estatuto de profissão de desgaste rápido do bailarino de dança contemporânea (recentemente foi aprovado para o bailarino de dança clássica). Definição de tabelas salariais (a [entidade] criou tabelas salariais para os seus bailarinos que têm sido implementadas por outras estruturas). Revisão do funcionamento da lei que rege os contratos de trabalho por periodos intermitentes e divulgação de como a implementar.

[479 - dança, teve apoio]

Refere-se ainda o reforço do apoio às entidades por parte da DGArtes no acesso a outras fontes de financiamento (nacionais e internacionais), assim como o apoio à capacitação dos recursos humanos das entidades relativamente às questões laborais e de financiamento. Neste âmbito, encontram-se também diversas propostas de revisão da Lei do Mecenato.

G6

Uma lei de mecenato que realmente valha a pena para as empresas e os privados. Facilitar o acesso das estruturas ao estatuto que Ihes permita beneficiar deste tipo de apoio. Incentivos às autarquias para o apoio às artes. Uma legislação fiscal mais sensata, mais adequada à realidade de quem é precário: tal como está, não só incentiva a fuga aos impostos como penaliza extremamente quem cumpre.

[16 - teatro, nunca concorreu]

6

Reconhecimento automático das entidades apoiadas de interesse público cultural, permitindo acesso imediato e automático aos efeitos da Lei do mecenato e código de IVA, independentemente da sua personalidade jurídica (Por exemplo: sociedade por cotas com fins lucrativos).

[63 - dança, teve apoio]

66 Parece-nos importante:

a) Redefinir a legislação do sector das Artes que regule áreas que carecem urgentemente de regulamentação específica e atualizada, nomeadamente, a carreira do artista, o apoio às artes, o mecenato e as parcerias estratégicas entre o sector independente e o sector público;

b) Repensar transversalmente a regulação do enquadramento fiscal e de segurança social do sector, nomeadamente no que respeita ao IVA aplicado aos biIhetes de espetáculo e outros bens e serviços culturais, o enquadramento das atividades profissionais nos diferentes regimes de tributação e as questões específicas no quadro da mobilidade internacional;

c) os orçamentos devem respeitar tabelas de custos com limites máximos de comparticipação do Estado, seja para despesas logísticas, seja para honorários ou outros itens. Na fase de avaliação das candidaturas, as disparidades ao nível 
dos custos, nomeadamente dos honorários, devem ser avaliadas e pontuadas em conformidade;

[326 - dança, teve apoio]

Por fim, e em menor número, identificam-se ainda um conjunto de posicionamentos que consideram as questões laborais e da precariedade como não relevantes no âmbito do Modelo de Apoio às Artes. Os argumentos mobilizados salientam principalmente que a precariedade é uma característica intrínseca à profissão (trabalho independente, como freelancer e/ou por escolha própria/opção). Outros argumentam que esta é uma questão transversal a diferentes sectores e predominantemente uma questão da competência de outras áreas ministeriais.

\section{Apoios interministeriais}

O questionário inclui uma pergunta abrangente sobre a possibilidade de conjugação dos apoios atribuídos pela tutela da cultura e por outros ministérios ${ }^{48}$. As respostas dão conta de múltiplas implicações a ter em conta, desde a reflexão sobre a bondade de tais articulações intersectoriais, até à sugestão de eventuais medidas operacionais, passando pela definição de normativos e recursos necessários. São apresentadas neste capítulo citações de respostas relevantes de acordo com os seguintes tópicos: opinião; objetivos e procedimentos administrativos; financiamento; medidas e programas específicos.

A articulação entre os apoios da tutela da cultura e apoios de outros ministérios é em geral valorizada, em especial se (ou na condição de) corresponder ao aumento do financiamento disponível. Por outro lado, embora menos frequente, é muito expressivo um posicionamento crítico sobre essa articulação e de defesa da autonomia do sector cultural.

Essa oposição é mais clara quando estão em causa critérios de apreciação não estritamente artísticos. A possível ligação a outros sectores é valorizada, por exemplo, na articulação com a comunidade local ou na educação (embora neste caso haja a remissão para a necessidade de as políticas educativas terem um maior espaço para a produção artística); os posicionamentos são bastante

\footnotetext{
${ }^{48}$ Q34. Como encara soluções de apoios que envolvam diferentes sectores interministeriais (por exemplo, cultura e educação, cultura e ciência \& tecnologia, cultura e ambiente, cultura e economia)? A taxa de resposta é $79 \%$.
} 
mais divididos quando se trata de considerar os efeitos económicos da atividade cultural (em particular, quando se considera a eventual ligação com o turismo).

Verifica-se uma leitura negativa das implicações processuais como a falta de clareza das estratégias políticas implicadas e o aumento da burocracia.

\section{Opinião}

A maior parte das entidades é favorável de modo geral à combinação de medidas envolvendo diferentes áreas de governação. Preservar os apoios já existentes é uma preocupação comum, enunciada como condição de partida, defendendo-se outro tipo de apoios numa lógica complementar.

Note-se também que uma opinião favorável surge associada a incentivos existentes em enquadramentos de cooperação internacional (por exemplo, programas europeus).

\section{Favorável}

6 Desde que seja através de apoios específicos que não invalidem os apoios já contemplados, é sempre positivo a ligação da cultura a outros eixos fundamentais da sociedade contemporânea como a ciência, a educação e o ambiente.

[428 - artes plásticas, concorreu mas nunca teve apoio]

66 Será um caminho obrigatório e natural porque é o que já acontece no trabalho de muitas entidades (é pelo menos a nossa experiência). O cruzamento com instituições de ensino e investigação, a integração de novas tecnologias, etc. Será muito importante perceber que as entidades podem ter um papel importante no relacionamento com instituições de outras áreas (propondo problemas, etc.), principalmente numa altura em que todo o esforço de investimento parece estar a ir para essas áreas (de tecnologia).

[419 - música, teve apoio]

66 Encaramos de bom grado. Já devia de existir à muito essa sinergia entre os vários Ministérios para o desenvolvimento de projetos eficazes e pertinentes na área da Educação, turismo, meio ambiente, entre outros. Não por uma questão financeira mas sim pelos resultados que essa sinergia poderá desenvolver e promover no futuro.

[509 - teatro, concorreu mas nunca teve apoio] 
66 Dependendo de cada projecto pode ser pertinente estabalecer pontes com os diferentes Ministérios. Acrescentaria o Ministério dos Negócios Estrangeiros. Mas as candidaturas de apoio da DGARTES devem manter-se genéricas e sem áreas específicas que concionem os projectos artísticos. De repente, no único apoio Pontual do ano ser majorado trabalhar com artístas da CPLP, condiciona a criação dos projectos artísticos. Devem sim ser programados apoios complementares e independentes para outras áreas relacionadas (por exemplo, cultura e educação, cultura e ciência \& tecnologia, cultura e ambiente, cultura e economia).

$$
\text { [465 - fotografia, teve apoio] }
$$

\section{6}

Encaramos de forma positiva, fomentará seguramente o surgimento de novas sinergias na comunidade e ao diálogo entre diferentes sectores que seguem fins semelhantes. É uma forma atractiva de cooperação.

$$
\text { [457 - teatro, teve apoio] }
$$

66

De um modo positivo, não só pela possibilidade e aumento de recursos mas também pela efeito em termos de legitimação da criação artística; mas desde que esta valorização das externalidades não faça perder de vista o valor intrínseco da criação artística (simbólico, espiritual, identitário).

$$
\text { [209 - teatro, teve apoio] }
$$

66 Urgente e altamente necessário. Embora os quadros de apoio para a área da
educação e ciência e tecnologia (os que investiguei na minha prática) quer na-
cionais através do Portugal 2020 quer internacionais (H2020 e Erasmus +) inte-
grem a possibilidade de inclusão dos agentes culturais a verdade é que na prá-
tica é muito dificil para as pequenas estruturas culturais conseguirem competir
e estabelecer as parcerias necessárias para esturutrar projectos vencedores.
Na prática, a cultura existe como uma intenção, uma afirmação 'politicamente
correcta' sem mecanismos que a tornem viável. Seria contudo importante que
estas soluções de apoio não substituam as estritamente culturais mas as com-
plementem. Cultura e ciência e tecnologia, é igualmente urgente e altamente
necessário [205 - artes digitais, teve apoio]

\section{Desfavorável}

Ainda que a maioria das opiniões sejam favoráveis à ideia de transversalidade sectorial, observa-se uma parcela relevante de entidades que explicitam reservas de princípio, justificadas pelo receio de perda de autonomia das áreas da cultura e limitação da liberdade criativa. 
6 Com muita reserva. Por exemplo, a ligação entre o Ministério da Cultura e o da Economia tem produzido projectos de qualidade muito duvidosa. Exemplo: Allgarve.

[462 - artes plásticas, teve apoio]

66 Com alguma reticência. A cultura não deveria ter de ser suportada por justaposição a outras áreas, e a DGArtes deveria afirmar a área da Cultura como uma área que vale por si.

[114 - artes plásticas, teve apoio]

66 Acho perigoso para o futuro da cultura e da arte: como disse anteriormente, a avaliação de projectos artísticos não deve obedecer a critérios económicos, de educação, de ciência, de ambiente, etc etc. Claro que a cultura é transversal, podendo ser de grande valor para outros sectores. Mas subordinar a criação e programação artística a protocolos com esses sectores ministeriais é "matar" qualquer incentivo à descoberta/ vitalidade criativa.

[83 - cruzamentos disciplinares, teve apoio]

66 Encaramos como fait-divers. Novamente, os apoios às artes fundam-se no princípio constitucional de promoção da liberdade de criação artística, como liberdade de invenção, produção e difusão, e isto é correcto e tem que ser cultivado. A função essencial que o Estado pode e deve desempenhar em relação à criação independente, é a de a apoiar.

[416 - cruzamentos disciplinares, teve apoio]

6 As verbas do Ministério da Cultura não devem servir projetos que na sua génese apresentam uma preocupação maior com temáticas da responsabilidade de outros setores ministeriais.

$$
\text { [429 - teatro, teve apoio] }
$$

64 Não parecem relevantes para o novo modelo de apoio às artes.

[106 - música, teve apoio]

66 Preocupemo-nos primeiro com a Cultura e com o real desenvolvimento de tecidos culturais altamente criativos e desenvolvidos intelectualmente. Preocupemo-nos depois com os "cruzamentos".

[381 - teatro, concorreu mas nunca teve apoio] 


\section{Objetivos e procedimentos administrativos}

Um denominador comum aos posicionamentos favoráveis e desfavoráveis a políticas intersectoriais é assegurar a esfera de competências própria do Ministério da Cultura e a atuação da DGArtes.

6 Fundamental o trabalho em articulação dos ministérios equacionados de modo a que possa beneficiar os agentes culturais, cabendo à DGArtes ou Ministério da Cultura a direção e divulgação de programas conjuntos que existem, de forma a que sempre em concurso público as entidades culturais possam concorrer. A maior parte de projetos conjuntos entre estes ministérios, como não são do domínio público e o ministério da cultura não os divulga aos seus agentes, acabam por beneficiar apenas uma minoria privilegiada de proximidade.

[372 - teatro, teve apoio]

66 Apesar da importância do relacionamento entre áreas (Cultura, Ciência, Educação, Economia, Turismo), não deve perder-se o âmbito artístico, de criação, dos diferentes projectos. Mais do que pedir às companhias para investirem nesse parâmetro com dinheiro público atribuído pela DGArtes, devia solicitarse aos organismos dedicados à Economia, ao Turismo, à Ciência, à Educação, para investirem, nesses âmbitos, a par da DGArtes. Ou seja, é importante manter o cariz de apoio à criação artística por parte da DGArtes.

[414 - teatro, teve apoio]

6 Muito interessantes. Mas não podem ser determinantes na acção do MC. São relações que o MC deveria incentivar sim sem abdicar da sua missão, nem submeter a criação artística a critérios exteriores.

[95 - teatro, teve apoio]

G6 A cultura não deve estar ao serviço do ambiente, do turismo, da educação, etc. Se determinada estrutura desenvolver um trabalho, fruto da sua identidade artística, que tenha relação com outras áreas, pode e deve procurar apoios suplementares, mas não devem ser os ministérios "mais fortes" a estabelecer a política cultural ou a decidir apoios, sob pena de se assentar a ideia de Cultura como instrumento ao serviço de outras áreas "mais importantes".

$$
\text { [377 - teatro, teve apoio] }
$$

6 As soluções de apoios que envolvam diferentes setores interministeriais parecem-nos muito úteis como forma de aumentar o investimento em projetos que, pela sua especificidade, possam constituir mais-valias em diferentes 
áreas, ou no caso da resolução de questões como a precaridade, como referimos em Q33. No entanto estes apoios não devem substituir ou aligeirar a responsabilidade do Ministério da Cultura/DGArtes no que ao investimento (apoio direto), para nós ainda muito reduzido, diz respeito. Estas aberturas podem e devem alimentar uma cooperação desejável entre diferentes áreas sociais, do conhecimento e do saber, não servindo como "desresponsabilização" do Ministério da Cultura/DGArtes.

[273 - teatro, teve apoio]

Um posicionamento favorável em termos de princípio é muitas vezes conjugado com uma preocupação face a dificuldades previstas de operacionalização, sendo nesse caso aventadas possíveis soluções administrativas (por exemplo, novos procedimentos concursais, ou a criação de comissões especializadas).

66 A ideia parece excelente mas a sua implementação não deve tornar ainda mais difícil a vida das entidades...

[179 - outra área, teve apoio]

66 Encaramos da melhor forma. Cabe ao Ministério da Cultura promover novos concursos públicos, extra DGArtes, direccionados para os diferentes tipos de apoio interministeriais (cultura e educação; cultura, ciência \& tecnologia; cultura e ambiente; cultura e economia). No entanto, que estes apoios interministeriais tenham em conta a possibilidade de integrar projectos de pequena dimensão e não se foquem apenas em projectos de grande dimensão orçamental, podendo assim dar também oportunidade às estruturas emergentes.

[489 - cruzamentos disciplinares, teve apoio]

6 Podem ser profícuas mas apenas caso sejam criadas novas ferramentas para além dos concursos e que tenham orçamento distinto.

[311 - cruzamentos disciplinares, teve apoio]

66 Era preferível haver um departamento no Ministério ou na Secretaria de estado da Cultura para tratar essas ligações com os outros Ministérios, integrando pessoas com uma formação específica de cada outro MInistério.

[93 - dança, teve apoio] 
Um aspeto sublinhado em relação a eventuais quadros normativos ou medidas que venham a ser definidos é a necessidade de garantir procedimentos transparentes e o livre acesso a todos os potenciais interessados.

66 os apoios visam as grandes organizações culturais deixando de fora os agentes em áreas associadas à gestão, empreendedorismo e inovação nomeadamente as empresas startup, micro e sme que detêm projectos ligados às áreas culturais e criativas

$$
\text { [78 - cruzamentos disciplinares, nunca concorreu] }
$$

66 Parece-me bem desde que não sejam impostos ou que sejam um factor de majoração nas candidaturas.

$$
\text { [206 - dança, teve apoio] }
$$

6 Poderiam ser interessantes, embora se possa correr o risco de criar modalidades de apoio para conteúdos artificiais, existentes apenas pela necessidade de criar cruzamentos determinados por critérios meramente administrativos e não artísticos/criativos.

[111 - música, teve apoio]

6 Estes envolvimentos só podem ser positivos. Quanto mais áreas estiverem envolvidas melhor e de forma mais estruturada evoluímos como país. Porem estes programas de apoio deveriam ser tornados públicos conjuntamente e com regras a que todos pudéssemos concorrer e não por convite directo como já tem vindo a acontecer.

[52 - música, nunca concorreu]

6 Achamos muito bem, desde que não se multipliquem as burocracias e os serviços onde se podem solicitar esses apoios (que essa interacção interministerial se faça através da DGArtes, por exemplo).

[366 - música, teve apoio]

G6 Concordamos com tal medida desde que haja uma lista de entidades apoiadas e profissionais a qual deve sim ser comunicada e utilizada por outros ministérios, mas pela perspectiva de aquisição de produto cultural certificado! "Intercâmbios" não! Pois estes facilmente conduzem à situação de indefinição entre Educação / Cultura / Animação...

$$
\text { [348 - música, teve apoio] }
$$


66 Positivamente. MAS com receio de uma falta de transparência na "adjudicação" desses apoios: Como são distribuídos? Por concursos? Quais regulamentos? Com júris? Quais júris? Qual é competência dos seus membros (será que um representante do Ministério da Economia tem competência para julgar da pertinência de um projecto artístico ou de um local onde se vai produzir um artista)? Quando são anunciados? Qual montante? Por qual tipo de projecto? Etc. Com receio que os procedimentos ficam desproporcionalmente complexos para estruturas com projectos modestas poderem concorrer. Com receio que esses apoios ficam apenas reservadas a projectos "mainstream" (Joana Vasconcelos, Vhils, etc.)

[211 - outra área, teve apoio]

66 Independentemente da necessidade de reforço financeiro ao Ministério da Cultura, parece-nos que a concretização dessa possibilidade seria não só uma enorme mais-valia, mas também um desafio, um estímulo, do ponto de vista da criação artística. Teriam contudo que ser encontrados, para efeitos destas parcerias, procedimentos concursais específicos, justos, simples e eficazes.

[487 - outra área, teve apoio]

66 É sempre desejável o entrosamento entre ministérios no sentido de encontrar apoios suplementares que possam vir a fazer face às necessidades sentidas no terreno pelas entidades aí inseridas, em função da procura de desenvolvimento cultural de uma região. Porém, tememos que, essa mais-valia, venha acarretar uma enorme carga burocrática, que em nada beneficiará a cultura em Portugal.

[432 - teatro, teve apoio]

\section{Financiamento}

Previsivelmente, a questão específica do financiamento de novas iniciativas interministeriais é um dos tópicos mais referidos, realçando-se, numa aceção instrumental, a possibilidade de diversificar e aumentar fontes de financiamento ou maximizar as verbas da área da cultura.

G6 É fundamental a procura de fontes de financiamento diversificadas fora do ministério da cultura. A diversidade de apoios por parte de outros sectores interministeriais seria uma forma de aumentar o apoio, mas também ter criação aplicada às linhas de acção dos diferentes ministérios. Situação que hoje acontece naturalmente mas sem o apoio directo vindo desses ministérios.

[364 - teatro, teve apoio] 
66 Achamos muito importante que haja soluções interministeriais onde a cultura surja na equação. Por falta de apoios na área da cultura, é prática comum concorrer a apoios na área da industria, agricultura, ciência, ambiente e depois tentar adapta-los de forma a conseguir trazer mais dinheiro para criação artística. É importante estabelecer linhas de apoio de intersecção, mas esta só pode ser uma fatia dos apoios a conceder. É importante que haja apoio exclusivo a projectos culturais.

[491 - cruzamentos disciplinares, teve apoio]

6 Haveria muito a ganhar e rentabilizaria o orçamento da cultura, na medida em que se iriam buscar outras verbas a outros ministérios, suprindo-lhes necessidades (como certamente a tutela do turismo comprovará).

[289 - cruzamentos disciplinares, teve apoio]

6 Os apoios que envolvam diferentes sectores interministeriais podem ser positivos desde que seja claramente divido e limitado o orçamento de cada sector. Tendo como base deste cruzamento a facilitação logística, legal, etc, e não forçosamente a osmose financeira dos apoios de um sector por parte do outro.

[102 - arquitetura, nunca concorreu]

6 Consideramos positivo, desde que não seja exclusivo modo de apoio e que seja coerente com o perfil de cada apoio em causa. Esta poderia aliás ser uma solução interessante para o aumento de verbas para a cultura - nunca para a diluição das parcas verbas já ao dispor deste sector. Por exemplo, não seria natural a existência de uma modalidade de apoio às artes que fosse específica para um tipo de público, mas seria muito interessante a existência de um concurso extra, que fosse duplamente tutelado pelo Min. Cultura e pelo Min. Educação, com o intuito de promover a circulação de obras destinadas a públicos jovens pelas diferentes regiões do país. Do mesmo modo, na área dos cruzamentos disciplinares arte\& ciência, arte\& ambiente ou arte\&pensamento/ ciências sociais, em que já existem percursos, obras e programações com relevância que poderiam deste modo ser aprofundados e qualificados.

[376 - dança, teve apoio]

6 Estas soluções são muito desejáveis, mas caberá ao Estado promovê-las criando, sempre que se afigure pertinente, novas linhas de financiamento que promovam essa articulação interministeriais.

[481 - dança, teve apoio]

66 Entendo que a cultura pode e deve ser transversal a estes diferentes domínios. São muitas vezes complementares e contribuem, muitas vezes, para o maior 
sucesso das iniciativas. Encaro, por isso, de forma muito positiva que se encontrem soluções capazes de dar resposta a este enquadramento. Encaro de forma ainda mais positiva se isso significar maior dotação financeira dos ministérios para apoio a estes projetos.

[42 - música, teve apoio]

66 Como justificámos ao longo de todo este inquérito: são absolutamente essenciais e um dos factores que pode ajudar a inverter a actual situação. Existem fundos que já envolvem na sua definição o sector da cultura, mas não estão a ser direccionados para o mesmo. Estão mesmo a ser abusivamente aproveitados por outros sectores que não incluem nos seus critérios de avaliação critérios culturais (ex: fundos para o desenvolvimento local, património cultural...). o Ministério da Cultura devia fazer um levantamento de todos os programas que fazem este cruzamento e proteger o interesse da Cultura chamando a si a responsabilidade de gerir alguns desses fundos.

[49 - outra área, teve apoio]

\section{Medidas e programas específicos}

A articulação entre os ministérios da Cultura e Educação é a mais citada e consensual, mesmo quando são avançadas novas iniciativas. Pelo contrário, a ligação entre cultura e economia (e turismo, muito especialmente) é a que desperta reações mais polarizadas

46 Dito isto, a [entidade] defende a criação e manutenção de programas de cofinanciamento que tenham os projectos artísticos como foco, e não apenas como complementares ou instrumentais - e num contexto em que tantos outros programas (os previstos no Portugal 2020, por exemplo) já colocam a cultura como subsidiária de outras agendas, pelo menos que a DGArtes mantenha o seu foco na missão de financiar a criação artística.

[464 - teatro, teve apoio]

66 Encaramos com ceticismo esta possibilidade. Sem a abertura de concursos específicos que englobem diferentes ministérios é dificil haver concretização objetiva. Pensamos que o setor cultural e o setor da educação deveriam trabalhar sempre em articulação, constituindo um Ministério conjunto. Esta articulação também deveria acontecer ao nível do poder local.

[410 - teatro, teve apoio]

6 Acho essas interligações muito justas e úteis. Fazer levantamentos dos projectos que já estão a ser desenvolvidos no terreno com essas vertentes múltiplas 
(arte, educação, ciência, ambiente, etc.) pode ajudar a conceber e desenhar modelos de apoio para esse tipo de acções

$$
\text { [358 - teatro, teve apoio] }
$$

64 A cultura e a economia devem estar atualmente de mãos dadas, seja pelo desenvolvimento económico direto, quando falamos em economia criativa, seja pelo apoio ao desenvolvimento do turismo num país como Portugal. Assim, cremos que esta será a ligação mais óbvia.

[165 - outra área, nunca concorreu]

66 A única associação de ministérios que nos parece relevante seria a da Cultura e Educação particularmente no caso dos projetos dirigidos a um público jovem. Existe um modelo desse tipo de colaboração na Bélgica francófona que tem 30 anos de existência - aconselhamos a sua análise.

[474 - cruzamentos disciplinares, teve apoio]

66 Apesar da grande importância que deve ser dada, muito em particular, à relação da cultura com a educação, não sentimos a necessidade de que estes projectos sejam especificamente apoiados no âmbito dos concursos. Na verdade os orçamentos da educação e da cultura são tão diferentes, e os recursos da cultura tão diminutos, que tal seria um peso desnecessário para estes mesmos orçamentos, já tão reduzidos. No entanto, consideramos que a educação deveria contemplar, obrigatoriamente, o lugar da cultura nos processos educativos. Tal decisão, para além de contribuir grandemente para a agilidade do pensamento e a abertura de horizonte intelectual nos jovens, teria igualmente, um efeito directo e muito substancial na criação de novos públicos, bem como na empregabilidade dos artistas.

[418 - cruzamentos disciplinares, teve apoio]

6 Muito positivas. Contudo não são referidos por vós ministérios como o dos $\mathrm{Ne}$ gócios Estrangeiros e o da Economia que deveriam ser prioritários. A política cultural do país deveria ser participada pelo MNE, por exemplo, que a pode usar para políticas de soft power.

[123 - design, concorreu mas nunca teve apoio]

6 Esta é uma ideia que esta entidade vem tentando desenvolver, incluindo não apenas os diferentes setores interministeriais, como as principais empresas do país e grandes organismos públicos, como o Instituto Camões, Turismo de Portugal, Municípios e Banca. Neste sentido, esta entidade entregou no Ministério da Cultura um dossiê que contempla este mesmo conceito.

[271 - música, teve apoio] 
6f Sugerimos que a componente de 'serviço educativo' deixe de figurar nos processos de candidatura. Em alternativa, as estruturas interessadas deverão concorrer directamente, e sublinhamos directamente, a programas específicos lançados, conjuntamente pela DGArtes e pelo ME ou pelas suas direcções regionais. O mesmo se aplica a outros sectores do conhecimento: ciência, tecnologia, ambiente, economia...

[461 - teatro, teve apoio]

6 Encaramos bem e sentimos necessidade. Mas reconhecemos pela prática que - Ministério da Educação é uma máquina pesada e burocrática. Que as Universidades estão num momento também de precariedade financeira e esgotamse em lutas internas, usando como estratégia, valorizar o seu conhecimento para avocarem todos os financiamentos externos. Defendemos, porque temos disso experiência, que os profissionais das artes, podem dar contributos importantíssimos em muitas áreas do saber universitário. Mas temos consciência que também não é simples.

[229 - teatro, teve apoio]

6 Achamos fundamental o cruzamento de políticas entre ministérios. Não entendemos, aliás, que no caso da cultura e educação, ou cultura e ciência, não existam entendimentos firmados e grupos de trabalho e de missão específicos.

[62 - teatro, teve apoio]

66 A interação entre estes sectores pode ser positiva, sempre que não promova uma instrumentalização da arte ao serviço de outras áreas. A ligação dos projetos teatrais com a educação, por exemplo, não podem reduzir o espetáculo à reprodução de conteúdos programáticos das disciplinas, como meros auxiliares didáticos nas escolas, mas sim contemplar os aspectos positivos da experiência artística para o desenvolvimento das crianças e dos jovens.

[484 - teatro, teve apoio] 


\section{Critérios não artísticos}

O questionário inclui uma pergunta sobre a utilização de critérios não artísticos na apreciação de candidaturas ao apoio às artes ${ }^{49}$. A maioria das opiniões é favorável a iniciativas interministeriais (contempladas na questão 30), o que indicia a concordância sobre transversalidade entre cultura e outras áreas; a mesma concordância não se verifica relativamente às implicações mais tangíveis de critérios que remetem para aquelas outras áreas. Neste caso, observa-se uma maioria de opiniões negativas.

Em todo o caso, não se trata da simples dicotomia entre aceitar ou não tais critérios transversais (inclusão social, interculturalidade, acessibilidade, turismo, inovação ou criação de emprego). Em geral, é reconhecida a importância das matérias subjacentes a tais critérios, que aliás são explicitamente referidos como possível matéria do trabalho artístico. Mas impõe-se a este respeito a recusa de utilizá-los como critérios formais. Estão, portanto, em jogo várias dimensões de reflexão, que são apresentadas de seguida: opinião; valor intrínseco/extrínseco da arte; parâmetros avaliativos; financiamento; burocracia; transversalidade.

\section{Opinião}

A especificidade própria do sistema de apoio às artes e o risco de instrumentalização face aos objetivos de outras políticas sectoriais são os principais argumentos de recusa da utilização de outros critérios.

\section{Opinião negativa}

66 Tratando-se de um apoio às artes, a avaliação deve ser feita apenas por critérios artísticos.

[331 - arquitetura, teve apoio]

\footnotetext{
49 Q35. Em que medida o apoio às artes deve ter em conta outro tipo de critérios de apreciação das propostas que não apenas os estritamente artísticos (por exemplo, inclusão social, interculturalidade, acessibilidade, turismo, inovação ou criação de emprego, ou outros)? Por favor fundamente a resposta. A taxa de resposta é $79 \%$.
} 
6

apenas os ESTRITAMENTE ARTÍSTICOS!!

[158 - artes plásticas, teve apoio]

66 Não deve ter. As artes não têm como objetivo criar oferta turística, não têm como objetivo criar emprego, não têm como objetivo incluir socialmente minorias. $\mathrm{O}$ estado tem essa rensposabilidade, as artes não. No entanto, como agentes que se inscrevem na esfera pública devemos abordar estas questões de forma refletida. Mas como já dissemos anteriormente, os apoios às artes são apoios às artes e não apoios à criação de emprego ou apoios à promoção turística.

[139 - artes plásticas, teve apoio]

6 Discordamos em absoluto. A instrumentalização do trabalho artístico e cultural é perigosa. O projecto deve ser avaliado no seu todo, na sua coerência artística e na consistência do projecto de gestão. Há projectos singulares em sim mesmos aos quais se deve exigir uma boa gestão e planeamento.

[244 - cruzamentos disciplinares, teve apoio]

64 Não deve, pelo menos no apoio à criação. Deverá haver programas específicos para esse tipo de modalidades em articulação e apoiados pelas entidades reguladoras específicas.

[351 - cruzamentos disciplinares, teve apoio]

66 Não deve ser um critério de apreciação nos concursos da DGARTES. Um projecto com uma forte componente de criação de públicos na área do turismo deve ser apoiado pelo Turismo de Portugal e a mesma coisa para a àrea da Educação. Estes apoios podem e devem ser articulados com a DGARTES mas não podem condicionar os únicos concursos de apoio às artes que existem .

[465 - fotografia, teve apoio]

\section{Opinião positiva}

Entre as razões de apreciação positiva de outros critérios está a abertura a uma maior diversidade e a novos temas artísticos, num processo de transformação que por vezes é apontado como estando já em curso.

66 É uma perspectiva que abre campos. Urgente dar espaço à procura que sustente a inovação.

[270 - artes plásticas, teve apoio] 
46 Esse tipo de critérios deveriam ser já norma na apreciação das propostas pois vão de encontro às preocupações artísticas contemporâneas a nível internacional e tendem a acrescentar pluralidade, interdisciplinaridade e mais justiça social ao mapa cultural nacional.

[428 - artes plásticas, concorreu mas nunca teve apoio]

6 É importante inovar e essas vertentes são importantes,mesmo que não haja uma grande adesão.

[302 - artes plásticas, teve apoio]

6 Bastante útil como forma de ampliar o orçamento dos apoios e, subsequentemente, o número/valor dos autores e sua produção.

[196 - outra área, nunca concorreu]

6 Concordamos em absoluto com a valorização de outros critérios de apreciação!

[486 - outra área, nunca concorreu]

G6 Considera-se que neste momento já são tidos em conta ou deveriam ser tidos em conta outros critérios, para além dos artísticos, nomeadamente para os cruzamentos disciplinares. Tendo em conta a evolução natural da sociedade, devem-se prever critérios que vão de encontro às políticas e práticas atuais e pilares fundamentais, como seja, a sustentabilidade, gestão de recursos, interculturalidade.

[355 - cruzamentos disciplinares, concorreu mas nunca teve apoio]

66 Achamos que as propostas que integrem outras acções de interesse para a sociedade, devem ser majoradas. Presentemente, as nossas propostas tentam integrar a inclusão social como factor importante.

[93 - dança, teve apoio]

\section{Valor intrínseco/extrínseco da arte}

A reflexão sobre a articulação entre valor intrínseco e extrínseco permite caracterizar o modo como as entidades artísticas entendem o contexto e efeitos sociais do seu trabalho. Observam-se perspetivas claramente diferenciadas: ora enfatizando os fatores que favorecem a identificação com a comunidade; ora 
valorizando a autonomia do trabalho artístico, remetendo temas de relevância social para políticas públicas específicas.

66 É nessa envolvência social e numa intervenção cultural mais amplificada pelas relações de proximidade, pelos desempenhos solidários e pelo comprometimento de defesa de causas públicas que a cultura atinge a sua notoriedade. É com estas práticas que se conquistam novos públicos e adesões a uma participação artística mais abrangente socialmente. É com a valorização destes critérios que o apoio às artes pode dar condições às estruturas para ganhar raízes e pontos de identidade sustentados que aproximam as pessoas dos agentes culturais, dos criadores artísticos, levando-as a identificarem-se com as realizações promovidas. Em suma, poderá abrir-se uma nova e fundamental página na valorização de critérios que não os estritamente artísticos.

[260 - cruzamentos disciplinares, teve apoio]

66 Não deveria ser considerado. Essas vertentes não devem ser excluídas, mas quando consideradas critério de majoração, estamos a condicionar a criação artística, tal como acontece com o Arts Council (uk) e a sujeição das entidades àquilo que é o applied Theatre or dance em detrimento de um trabalho de investigação artística.

[325 - cruzamentos disciplinares, teve apoio]

66 Os critérios de criação artistica devem ser separados dos critérios ligados ao trabalho de intervenção nas comunidades. Embora haja pontes possíveis de articulção, os princípios da ação e as estratégias de implementação são diferentes e, portanto, deve haver critérios distinos de apreciação. No que respeita à intervenção direta nas comunidades, as Câmaras Municipais devem incentivar essas práticas e acompanhar no terreno os projetos desenvolvidos.

$$
\text { [410 - teatro, teve apoio] }
$$

6 São todos critérios que nos parecem mais relevantes na avaliação de uma mediação cultural do que de um projeto artístico. Esse tipo de critérios pode ter como consequência fazer com que as entidades desviem os projetos ou condicionem as candidaturas. Os artistas têm os seus questionamentos, temas, linguagens próprios que querem desenvolver. Se o estado quiser um projeto intercultural, pode encomendar um projeto intercultural, por exemplo. Criar um concurso específico para isso? Uma bolsa anual?

[474 - cruzamentos disciplinares, teve apoio] 
66 Aí é que deveriam entrar os outros ministérios. E apoiarem projetos especificos. A arte ela própria não pode servir para tudo, não pode ser uma arte multi task.

[460 - teatro, concorreu mas nunca teve apoio]

\section{Parâmetros avaliativos}

A par da reflexão sobre valor intrínseco e extrínseco, a eventual utilização de critérios de apreciação não artísticos suscita um conjunto de críticas a respeito do processo administrativo de candidaturas crescentemente vistas como abstratas e distanciadas da proposta artística.

6 Como ja referimos numa resposta anterior pensamos que seria positivo incluir estes aspectos numa apreciação mas isso tambem requere uma formação para tal. As estruturas tem que saber onde podem desenvolver aspectos de majoraçao mas que nao sejam prejudicadas. Não pode ser tudo numeros e formulas num exel. Estamos a fala de experiencias de pessoas. O que é capaidade de gerar emprego? como se mede? o que é inclusao socia? como se mede. Como se mede uma experiencia artistica? No fundo são aspectos de formação de cidadania que sim merecem ser pensados por pesoas qualificadas. Portanto sim deve ser tido em conta mas com ponderação.

[208 - artes plásticas, nunca concorreu]

6 Penso que é muito difícil generalizar esse tipo de critérios, pois a natureza e proposta das entidades são muito dispares. Quanto mais critérios de avaliação houver, mais desigualdade haverá entre os apoios atribuídos.

[235 - cruzamentos disciplinares, teve apoio]

6 Os critérios de apreciação não estritamente artísticos só se justificam se os projetos em causa forem apoiados no contexto de uma linha de financiamento interministerial. Neste caso, concordamos que devem ser considerados critérios relacionados com os objetivos e prioridades dos diferentes sectores envolvidos.

$$
\text { [476 - cruzamentos disciplinares, teve apoio] }
$$

64 A oferta cultural contemporânea enquadra estes diferentes domínios. Não há dúvida que eles devem ser integrados como aspetos de apreciação das candidaturas mas, não me parece, que devam ser aspetos de majoração automática.

$$
\text { [42 - música, teve apoio] }
$$


6 Esta medida deveria ser demonstrada pela entidade candidata na base de um encontro direto entre o júri e os responsáveis da entidade, na base de perguntas que o júri poderá fazer para apreciar estes critérios. Isto é para evitar o crescimento de formulários que alcançaram dimensões exageradas, chegando ao ponto que a organização candidata já não é ela que escreve a candidatura, utilizando para o efeito profissionais na escritura de candidatura, profissionais que escrevem exatamente o que a Dg Artes gosta ver escrito nos formulários. Mas aqui voltamos à questão inicial: valoramos as entidades pela seu valor e a sua experiência ou a sua capacidade de escrever os dossier de candidatura, cada vez mais pesados e complicados?

[106 - música, teve apoio]

66 Devem ser critérios a considerar mas não factores de majoração. A criação e investigação nas áreas artísticas não podem estar obrigadas a responder a critérios que lhe são externos. A qualidade - e a criação de condições para que se consiga alcançar - poderá contribuir de forma muito mais eficaz, embora indirecta, para os critérios acima descritos.

[407 - música, teve apoio]

66 Têm critérios de apreciação a mais. No caso dos Apoios para criação, deveriam ser baseados em apenas 3 critérios: 1) a exposição do projecto, 2) a formação/experiencia profissional dos intervenientes 3 ) o orçamento.

[211 - outra área, teve apoio]

G6 Concordamos plenamente que haja outro tipo de critérios, nomeadamente aqueles que são apontados, mas não compete às Entidades definir os novos critérios que deverão ser integrados na avaliação das propostas - depende da política cultural que for definida pelo estado.

[290 - teatro, teve apoio]

\section{Financiamento}

Tal como se observa a respeito da possível combinação de apoios do Ministério da Cultura e de outros ministérios, também a introdução de novos critérios de apreciação é vista como potencial acesso a mais canais de financiamento.

6 O apoio às Artes deve ter em conta critérios estritamente artísticos na análise das propostas a concurso, até ao patamar financeiro que viabilize dignamente 
a produção do programa/projecto proposto. A partir daí, outros critérios poderão ser considerados, sim, mas apenas como contributos para reforço de financiamento.

[487 - outra área, teve apoio]

6 Todos esses critérios (ou até outros) podem e devem ser considerados na justa medida em que os apoios sejam alargados através do anteriormente referido envolvimento de outros ministérios (e dos respectivos orçamentos), no que a cada critério seja relevante.

[198 - teatro, nunca concorreu]

6

Deve ter em conta de uma forma limitada. O objectivo dos apoios às artes deveria centrar-se na criação artística e não na sua maior ou menor capacidade de se relacionar com matérias que devem ser asseguradas ou promovidas por outros intervenientes. Por exemplo: são os operadores turísticos que devem ser estimulados a interagir com a criação artística. 0 mesmo pode aplicar-se às instituições dedicadas à inclusão social ou a interculturalidade, etc. A intermediação entre os intervenientes poderia ser facultada, por exemplo, pelas autarquias ou associações de desenvolvimento local, através de estímulos financeiros.

[247 - teatro, teve apoio]

66 Esta questão está diretamente relacionada com o montante disponível. Apesar de acharmos que essas valências são muito importantes não se pode esperar que mantendo os níveis dos montantes as estruturas consigam adereçar todos os problemas.

[279 - teatro, teve apoio]

66 Há vários anos que praticamos este conceito e operacionalizamos projectos tendo obtido financiamentos razoáveis e muitas vezes superiores ao da tutela.

[267 - teatro, teve apoio]

\section{Burocracia}

A introdução de novos critérios é criticada como suscetível de aumentar dois riscos: complexidade processual desproporcionada; enviesamento das propostas artísticas na tentativa de adequação a objetivos administrativos. 
6 Os projectos devem ser avaliados pela sua natureza e valor intrínseco, independentemente da boa-vontade sectorial. A pergunta tem implícito um caminho que é cada vez mais tortuoso e burocrático, em que os projectos não são valorizados pela sua integridade mas sim pela capacidade de responderem a um conjunto de pontos que não têm qualquer relação com o seu valor cultural ou artístico.

[128 - arquitetura, concorreu mas nunca teve apoio]

6 Corre-se o risco, conforme mencionado acima, de criar cruzamentos determinados por critérios meramente administrativos e não artísticos/criativos. Por exemplo: o critério de majoração nos apoios pontuais a projectos que privilegiam a criação ligada à cultura de afro-descendentes. Embora não haja nada de condenável no critério em si, a sua previsível vigência até 2020 vai colocar sérias limitações à abrangência e diversidade dos projectos aprovados.

[111 - música, teve apoio]

6 Os nossos projectos não tem uma validade exclusivamente artística, pelo que diríamos que na avaliação das nossas propostas contariam as componentes de investigação, envolvimento, debate cidadão. O perigo de termos critérios exclusivamente artísiticos, é que o artísitico poderá ser encarado de forma ensimismada sem grandes retornos na sociedade. $O$ perigo de incluir outros critérios, em estruturas precárias e projectos de curta duração, é falsificarem-se resultados quanto a criação de emprego ou inclusão social, que nãos e resolve efetivamente em seis meses nem se mede com dados meramente quantitativos. E, infelizmente, a introdução destes critérios normalmente só é medida em números superficiais.

[24 - outra área, teve apoio]

6

Se já se verifica enorme discrepância na avaliação dos critérios actuais, entre candidaturas, estamos em crer que a insercão de novos critérios cavará, ainda mais fundo, essa discrepância. Aliás, a obrigatoriedade de submeter as criações a determinados temas, como acontece nos apoios pontuais, parece-nos, nesta tipologia de apoios, parece-nos uma intromissão nas escolhas artísticas dos criadores. Esses temas pré-definidos, só deveriam tornar-se 'obrigatórios' nas candidaturas plurianuais, a quatro anos, quando tempo de preparação de escolha de reportórios o permite. Não nos parece desejável a existência de critérios de pontuação, além dos que estão estabelecidos: o mérito da proposta vale por si. A dramaturgia contemporânea aborda, de alguma maneira, os temas referidos acima. Pontuá-los, torna-se redundante.

[461 - teatro, teve apoio] 
64 Julgo que os actuais concurso já têm demasiados objectivos e que os exemplos apontados já constam indiretamente na criação de objectos artísticos. Não devem ser valorizados somente projectos que promovam a intercultutalidade ou o turismo correndo o risco de só existirem projectos artísticos com esses critérios.

[307 - teatro, teve apoio]

66 Os financiamentos não devem ser reduzidos a máquinas de propor mensurações, mas antes assumir a sua capacidade de influenciar a estruturação da oferta cultural (de criação, programação e mediação), através da adopção dos princípios de qualidade, pluralidade e autenticidade.

[464 - teatro, teve apoio]

\section{Transversalidade}

Não obstante as reservas expressas a respeito dos procedimentos administrativos, a utilização de critérios não artísticos é considerada por algumas das entidades - naturalmente aquelas que lhes são favoráveis - como um vínculo de ligação às comunidades.

6 Por exemplo, a ligação com o turismo só faz sentido se o Turismo contribuir claramente com apoio financeiro; por exemplo porque não se fornece uma percentagem da taxa de ocupação turística para a cultura? Neste momento, o turismo ganha com a cultura mas a cultura não ganha nada com o turismo; mais uma vez a culura é o parente pobre que faz milagres com orçamentos ridículos.

[205 - artes digitais, teve apoio]

6 Por exemplo, no caso de projetos de investigação artística, os critérios de apreciação devem ser não apenas artísticos mas também científicos.

[11 - artes plásticas, nunca concorreu]

6 Esses critérios podem ser muito importantes, porque o papel dos agentes culturais é também o de saber envolver a comunidade nos seus projetos e como tal, os projetos devem ter finalidade de chegar a diferentes públicos e de intervir no dia-a-dia dessas comunidades e o chamar turistas a uma terra é tão importante como fomentar emprego ou a inclusão social, entre outros.

[172 - artes plásticas, concorreu mas nunca teve apoio] 
6 Deveriam ser vinculativo e considerados fator de majoração dos projetos a inclusão social, interculturalidade, acessibilidade, turismo, inovação, criação de emprego. Cada vez mais os projetos artisticos estão inseridos num meio social e económico e apresentam valencias para as regiões onde estão inseridos, em especial zonas interior do território.

[98 - dança, teve apoio]

6 Considera-se que este tipo de critérios deve ser muito bem enquadrado para que seja valorizado na avaliação de uma candidatura. Em verdade esses critérios deveriam ser elementos de valorização da qualidade e consistência de cada projeto como um todo, nos casos em que faz sentido que isso aconteça. Por exemplo, seria de valorizar a criação de emprego numa estrutura candidata, mas também as condições desse emprego, a localização e comunidade do projeto, etc. Por outro lado, não se deve perder de vista o projeto artístico valorizando em demasia estes aspetos.

[335 - dança, concorreu mas nunca teve apoio]

6 Achamos que todas as entidades devm ter um papel inclusivo, seja nas escolas, nos bairros, criação de públicos, mas também melhoria das condições de vida, que nem sempre terão de ser económicas. As entidades devem ser avaliadas principalmente pela acção que desenvolvem na sua comunidade e contribuem para melhoria de uma economia circular.

[47- design, nunca concorreu]

66 apoio às artes deve ter em conta outro tipo de critérios ou criar uma nova modalidade de área artística onde a arte é a ferramenta para trabalhar na inclusão social, entre outros. É fundamental, na nossa experiência ter em conta estas propostas, pois chegamos a novos públicos, a novas áreas de apoios, criamos melhores estruturas e envolvemos mais áreas na área da cultura. $\mathrm{Na}$ nossa experiência, do qual já trabalhamos já à algum tempo com projetos de integração pela arte, a cultura e a arte só chega a um público muito elitista, cada vez menos, felizmente, por isso é importante que os artistas trabalhem noutros meios, para que cada vez mais se democratize a arte.

$$
\text { [16 - teatro, nunca concorreu] }
$$

66 Considerando que a cultura e as indústrias criativas ocupam hoje uma fatia tão significativa da economia, parece-nos fundamental essa interligação com outras áreas. Nomeadamente na tão estreita relação entre a cultura e o turismo.

[449 - música, teve apoio] 
66 O subsídio com dinheiros públicos deve rumar para o desenvolvimento de projetos da comunidade criativa nacional que espelhem o atual contexto em que se inserem, que providenciem benefício das comunidades onde se inserem, devendo potenciar desenvolvimento local através dos factores enumerados (inclusão social, interculturalidade, acessibilidade, turismo, inovação, criação de emprego, etc...). Mais uma vez referimos que o fator geográfico (contexto onde a entidade artística atua e que públicos envolve) e a sua relação com a acessibilidade das comunidades a atividades artísticas deve ser um fator a ter em conta nos processos de avaliação de projeto. Nestes contextos mais isolados de grandes centros urbanos e consequentemente de uma maior possibilidade de fruição cultural e artística, devem ser valorizadas iniciativas que promovam o acesso das populações aos discursos artísticos, sem arrogância conceptual e acompanhado de preocupações didáticas e lúdicas, no sentido da acessibilidade às poéticas.

[154 - outra área, teve apoio]

\section{A avaliação do regulamento de apoio às artes}

Uma das perguntas finais no questionário solicita assumidamente contributos de carácter avaliativo, de sentido positivo e negativo ${ }^{50}$, do regulamento de apoio às artes. É, aliás, a única em que tal acontece. O levantamento dos argumentos aduzidos, em ambos os sentidos, consta da tabela 2. Procura-se com este levantamento dar conta, de uma forma sintética, da diversidade de argumentos sem preocupações de quantificação - o objetivo não é identificar o respetivo peso relativo, mas tão só dar uma perspetiva alargada da diversidade dos contributos expressos (identificando as temáticas no contexto em que foram formalizadas), tanto quanto possível organizados de mais gerais a específicos das políticas públicas, do enquadramento, da coordenação pela DGArtes e da plataforma eletrónica até ao acompanhamento e avaliação dos contratos, passando pela apresentação das candidaturas e sua apreciação.

Uma parte significativa das entidades ( $17 \%$ dos que preencheram o campo dos aspetos positivos e $11 \%$ dos que preencheram o campo dos aspetos negativos) optou por não se pronunciar invocando falta de experiência com o mo-

\footnotetext{
50 Q36. A partir da experiência da entidade, por favor identifique os aspetos positivos e negativos mais relevantes no atual modelo de apoio. A taxa de resposta é $71 \%$.

Q36.1. Aspetos positivos. A taxa de resposta é $67 \%$.

Q36.2. Aspetos negativos. A taxa de resposta é $72 \%$.
} 
delo de apoio - por não ter tido apoio e por não ter dados estão entre os argumentos expressos mais invocados. Por esse motivo rareiam as entidades que avançaram contributos para esta questão e que não tenham sido apoiadas.

Numa primeira leitura, o tom dos contributos oscila, de forma polarizada, entre a aprovação total, sem reservas ("bom modelo", "modelo adequado") à reprovação total ("nada de positivo" no modelo). Mas entre estes dois polos a palete é muito diversificada em qualquer dos sentidos. Os argumentos de sentido avaliativo positivo são mais genéricos, os de carácter negativo mais específicos e pormenorizados.

Quanto aos aspetos de sentido positivo, destacam-se: a própria existência dos apoios, a sua abrangência artística, territorial, de entidades, de domínios artísticos, a sua regularidade, o processo participativo e a realização do EPEA.

De sentido negativo referem-se: a escassez de financiamento no Orçamento do Estado para a cultura e para o MAA, bem como limitações específicas que se manifestam em aspetos mais gerais mencionados como positivos (e.g., centralismos de Lisboa e Porto, burocracia de procedimentos, irregularidade dos concursos, falta de comunicação da DGArtes, realização do EPEA que não esgota as necessidades de participação).

\section{Tabela 2. Aspetos positivos e negativos do regulamento de apoio às artes}

\section{Aspetos positivos}

- A existência dos apoios (permanência, continuidade)

- Modelo adequado

- Existência de um serviço público de teatro que abrange todo o território

- Abrangência (em n.ㅇ de projetos e território, em tipo de entidades coletivas e singulares)

- Formação de públicos

- Relação com DGArtes, comunicação, apoio dos funcionários, acompanhamento

- Transparência

- Democratização das medidas de apoio

- Processo de candidatura através de plataforma, existência de manual de apoio

- Liberdade estética

- Viabilização da criação

- Regularidade dos concursos

- Diálogo com as entidades

- Concurso público

- Apoios plurianuais 
(...)

- Apoio simultâneo às entidades e às atividades

- Explicação jurídica das queixas

- (Tentativa de) articulação com as autarquias

- Apoio à atividade com a comunidade

- Regras e objetivos que permitem uma maior clareza no investimento feito pelo Estado e responsabilização de todos os envolvidos

- Permite alavancar contactos e encetar parcerias

- Contratos plurianuais, para estruturas estáveis

- Interligação criação/programação

- Equilíbrio entre áreas artísticas

- Valorização da circulação

- Condições universais

- Apoio a atividades multidisciplinares

- Autonomia artística e de gestão

- A aposta na edição

- Variedade de modalidades de apoio

- Atividades de formação

- Estabilidade da relação entre parceiros (tripartidos)

- Permitir a articulação de entidades a nível local na montagem de projetos

- Contemplar apoios em espécie

- Apoio à internacionalização

- Apoio à criação contemporânea

- Divisão entre apoios regulares a entidades e apoios pontuais a projetos

- Potenciar a digressão dos projetos

- Contribuição dos formulários para a profissionalização das entidades

- Manual do candidato

- Existência de avaliação por júris

- Celeridade dos processos

- Fatores de majoração para descentralização

- Rigor na gestão financeira dos projetos

- Possibilidade de ligeiras adaptações ao longo do tempo

- Flexibilidade entre o programa proposto em concurso e o executado

\section{Aspetos negativos}

- Subfinanciamento crónico, fraca dotação orçamental do modelo

- Desarticulação com outros sectores governativos

- Desarticulação dos objetivos de política cultural

- [O próprio modelo na totalidade]

- Falta de cultura de planeamento estratégico

- Centralismo (de Lisboa, Porto, grandes centros)

- Apoios insuficientes (pontuais) 
(...)

- Dificuldades de antecipar prioridades estratégicas dos concursos

- Distanciamento da DGArtes face às entidades

- Inexistência de bolsas de mérito

- Calendário: dos concursos e de pagamentos

- Deficiente funcionamento da plataforma eletrónica

- Excesso de burocracia

- Clientelismo, privilegiar entidades estabelecidas

- Dificultar a coprodução

- Privilegiar critérios não artísticos

- Atrasos nas aberturas dos concursos e na saída dos resultados

- Excessiva compartimentação dos projetos elegíveis

- Assimetrias regionais não são tidas em conta na atribuição dos apoios

- Fraco apoio à internacionalização

- Não valoriza a criação original

- Volatilidade dos prazos e dos critérios

- Pé de igualdade entre entidades estabelecidas e emergentes

- Os formulários (desadequados)

- Falta de confiança e de conhecimento do sector

- A limitação de uma autarquia por apoio tripartido

- Ausência de critério de mérito

- Disparidade dos valores pelas áreas artísticas

- Avaliação quase exclusivamente quantitativa

- Legislação contraditória

- Falta de garantia de estabilidade das entidades

- Não razoabilidade de critérios ("montante solicitado")

- Não razoabilidade de fatores de majoração ("serviço educativo")

- Necessidade de adenda anual que implica atraso nas atividades no início de cada ano

- Reprodução das entidades que beneficiam de apoios quadrienais

- Exigência (irrealista) de programação e orçamentos para 4 anos

- Modalidades pouco permissivas a entidades amadoras

- Ausência de memória sobre o historial das entidades e seus diretores

- Prazos não cumpridos

- Falta de adequação dos programas à diversidade de propostas

- Mesmo concurso para os vários domínios de atividade

- Falta de clareza

- Baixo valor de financiamento por projeto

- Linhas de apoio contempladas na legislação que não são abertas

- Alteração frequente das equipas (na DGArtes)

- Não distinção entre entidades com estrutura e sala de espetáculos própria das outras

- Princípios demasiado economicistas 
(...)

- Ideia restrita, pouco plural da atividade artística

- Dificuldade para artistas sem estrutura receberem apoios

- Não haver concursos de âmbito regional

- Excluir expressões como as artes de rua, circo contemporâneo, criação em site-specific

- Difícil acesso por projetos de menor porte

- Não haver distinção entre áreas nos concursos

- Contribui para a discriminação negativa de agentes culturais com créditos firmados

- Desresponsabilização pelo cumprimento da lei laboral

- Desresponsabilização pelos impactos ambientais

- Calendarização mais adequada às artes performativas do que às outras áreas objeto dos apoios

- Inexistência de formação de como fazer uma candidatura para apoio

- Frequentes alterações dos critérios de apreciação

- Júris, composição: não especialização, (não) independência, desadequação, subjetividade

- Júris, não existência em algumas modalidades (pontuais)

- Declarações vinculativas da administração local, tripartidos (dependentes de questões políticas)

- Elevada majoração de financiamentos dos apoios fora das candidaturas

- Não ter em conta a quantidade de espetadores a que os projetos chegam

- Desvalorização das comissões de acompanhamento

- Fraca implicação das DRC

- Pouca proximidade com as entidades na avaliação

- Circulação como fator de valoração das candidaturas

- Falta de acompanhamento no terreno do apoio concedido

- Falta de acompanhamento das entidades/dos projetos não apoiados

- Subjetividade das classificações

- Parâmetros de avaliação rígidos

- Falta de respostas claras sobre avaliação

- Pouco acompanhamento e monitorização (sua falta)

\section{Aspetos positivos}

6 Bom atendimento e comunicação por parte de quem orienta os processos. Rapidez nos resultados, contratos e disponibilização das verbas.

[331 - arquitetura, teve apoio] 
66 Haver candidatura para verbas de apoio e não deixar as estruturas dependentes de estruturas locais.

[270 - artes plásticas, teve apoio]

6 a regularidade dos concursos, o diálogo com as estruturas e os criadores.

[490 - artes plásticas, teve apoio]

6 Manutenção de concursos plurianuais que permitem às estruturas o acesso a financiamento numa lógica de longo prazo.

[462 - artes plásticas, teve apoio]

6f É positivo que a DGArtes esteja neste momento a analisar o atual modelo de apoio e a considerar a voz das entidades neste processo. Esperamos que com esta análise se chegue a um novo modelo mais justo e adequado de apoio às artes.

[369 - artes plásticas, teve apoio]

66 Transparência O mérito da proposta é um factor determinante (meritocracia) Acesso em igualdade de condições para as diferentes entidades Regras claras

[144 - artes plásticas, teve apoio]

66 Uma das coisas mais positivas nas candidaturas da DGArtes, e comparativamente com outras candidaturas à cultura internacionais, é que os apoios de género são valorizados, e isso na nossa opinião deve ser mantido. Consideramos que os apoios em género são realmente uma forma real de apoiar os projectos, por vezes até superiores aos apoios financeiros a troco de visibilidade, pois geram um movimento de entre-ajuda e de parcerias que consideramos ser das coisas mais saudáveis no processo de produção das actividades que produzimos dentro dos apoios à DGArtes.

[114 - artes plásticas, teve apoio]

6 fundamental a existência de uma DGArtes. Modelar o funcionamento da mesma para um registo mais objectivo, funcional e próspero será importante, mas todo o empenho que já seja colocado na definição de uma política de apoio às Artes será sempre positivo.

[105 - outra área, concorreu mas nunca teve apoio] 
64 Existência de concursos de apoios às artes; Plataforma digital, processo digital; Existência de cruzamentos disciplinares; O Estado financiar uma parte da criação ou projetos e não a sua totalidade; Apoios à criação, programação e entidades mistas; Os concursos serem organizados fora da administração local; Os apoios às artes não serem atribuídos por programadores;

[70 - outra área, teve apoio]

6 Existir um modelo de apoio às artes é, em si, um espeto positivo!

[486 - outra área, nunca concorreu]

G6 É fundamental existir apoio às artes, independente de qualquer outro sector ministerial.

[83 - cruzamentos disciplinares, teve apoio]

66 Aspetos positivos: aqueles que, apesar de tudo, tem possibilitado a afirmação da vitalidade dos projetos apoiados que têm desempenhado, indubitavelmente, um papel relevante e crucial no desenvolvimento e afirmação artísticoculturais de Portugal. Poucos são os países que podem contar com o empenho, criatividade, inovação e militância cultural de profissionais das artes do espetáculo que tanto amam e generosamente oferecem o melhor de si a uma profissão que, nos últimos anos, se pode considerar de risco permanente.

[260 - cruzamentos disciplinares, teve apoio]

6 O sistema de repartição dos apoios entre às direções regionais A variedade das modalidades de apoio.

[474 - cruzamentos disciplinares, teve apoio]

66 modelo actual contribui para que os financiamentos do estado não sejam canalizados através de estruturas subsidiárias (modelo alemão).

[485 - cruzamentos disciplinares, teve apoio]

66 Em geral, o sistema de apoio às artes, através de contratos-programa vinculados a objectivos é um aspecto muito importante e louvável. É essencial manter vivo e melhorar esta forma de apoio e rejeitar contratos directos com companhias e projectos que se consideram, habitualmente por motivo de antiguidade e história, isentos de avaliação. Parece-nos, igualmente, correcta a divisão entre apoios regulares às estruturas e apoios a projectos pontuais.

[418 - cruzamentos disciplinares, teve apoio] 
6 Promove os cruzamentos disciplinares e dispõe de apoios variados (quadrienais, pontuais, etc.)

[54 - cruzamentos disciplinares, concorreu mas nunca teve apoio]

66 Artisticamente transversal fundamental no contexto Português Tem permitido ao longo dos anos a sobrevivência do sector, embora de forma precária.

[188 - cruzamentos disciplinares, teve apoio]

66 - A profundidade de análise do programa artístico, aquando da elaboração de uma candidatura, solidifica o próprio projeto e unifica as equipas de trabalho para um só inequívoco objetivo. É verdade que após a apresentação de uma candidatura, toda a equipa de trabalho, artística, de produção, difusão, gestão e outros, ficam unidas num só caminho, cúmplices, responsáveis e motivadas por uma causa comum. - Paridade com que os projetos são analisados.

[345 - dança, teve apoio]

66 Existência de concursos Existência de júris Diversidade de tipologias de concurso/ apoio (que poderia ser maior e mais específica) Apoio direto aos profissionais do Apoio simultâneo às estruturas e às actividades.

[376 - dança, teve apoio]

66 Mantém uma divisão sensata de áreas de apoio No geral existe uma boa interlocução A cartografia de apoio não está desajustada, embora possa ser melhorada.

[117 - dança, teve apoio]

66 Consideramos positivo que seja valorizada a realização de atividades de formação e sensibilização de públicos.

[363 - dança, teve apoio]

66 Existência de concursos publicos, Existência de apoios, Existência de alguma isenção na avaliação Existência de uma DGArtes e de um MC Existência de muitas estruturas de acolhimento, embora muitas não funcionem ou não tenham programação.

[479 - dança, teve apoio] 
66 - Possibilitar um apoio quadrienal - facilidade na partilha de informação - acompanhamento adequado por parte dos serviços da DGArtes

$$
\text { [435 - dança, teve apoio] }
$$

66 neste momento o que me parece positivo é a intenção de reformular e aprofundar os anteriores concursos tendo em consideração os resultados que este inquérito apurar.

$$
\text { [287 - dança, teve apoio] }
$$

66 Candidatura online; Concurso público; Financiamento ao sector das artes; Apoios a pessoas colectivas e singulares; Apoios pontuais, anuais e bienais;

[103 - fotografia, teve apoio]

6 A existência de apoios de longa duração (4 anos) e de ser possível adaptar ligeiramente o projecto às alterações sociais e quotidianas das entidades ao longo desse período. Sem desprimor pelo apoio às entidades emergentes, novos projectos e grupos jovens, há projectos de longa duração cuja experiência tem sido valorizada e que consideramos que esse critério é importante para o fortalecimento de redes e de projectos que já deram provas da sua eficiência e qualidade artística.

[500 - música, teve apoio]

66 aspecto mais positivo é o de que existe. E existe já há vários anos. Esses quadros sucessivos de apoio trouxeram um mínimo de estabilidade ao sector. De forma evidente, a introdução dos apoios plurianuais foi fundamental para o desenvolvimento das entidades. $O$ crescimento de exigências de gestão dos processos ajudaram as entidades (essa é a nossa experiência) a desenvolver melhores mecanismos de controle e acompanhamento das suas actividades. Funcionam também, inevitavelmente, como um processo de validação. Nesse sentido, o sucesso evidente de várias entidades que foram apoiadas ao longo dos anos é também o sucesso deste modelo, apesar de todas as suas limitações.

[419 - música, teve apoio]

66 Sempre é melhor que nada... muitas instituições ligadas à cultura souberam sobreviver à custa dos apoios às artes. Mas a maior parte delas não o conseguiu e isso deve-se aos vários factores críticos que atrás se referiram como os complicados questionários, a constituição (não especializada) dos júris atuais e que, por vezes, ultrapassam as regras estatuídas e , não o podemos esquecer, a lei do mecenato que se revela muito pouco atrativa junto dos possíveis mecenas; o pensar-se que tal lei não pode ser mais ampla, porque há que zelar pelos 
cofres do Estado, mas esquecem-se que, com estes apoios o mesmo acontece com o aumento da despesa estatal.

[204 - música, concorreu mas nunca teve apoio]

66 A tentativa de tornar objetivo o apoio às artes. A explicação pormenorizada em termos jurídicos de todas as queixas das entidades. A tentativa de tirar do controlo politico a atribuição dos apoios da Dg Artes. A tentativa de articulação com as Autarquias.

[106 - música, teve apoio]

6 A inclusão dos apoios tripartidos e a intenção de envolver o poder local e autárquico no apoio às entidades concorrentes. A avaliação positiva dos projetos em desenvolvimento e com provas de sucesso. A regularidade no pagamento dos apoios, a facilidade de comunicação e a prontidão na resposta da equipa que nos acompanha, assim como a compreensão na especificidade da nossa área artística na elaboração dos relatórios anuais.

[234 - música, teve apoio]

66 1) Apoio às entidades que mais têm demonstrado vitalidade e criatividade ao longo dos últimos anos - as que adquiriram um historial reconhecido e de prestígio. 2) A utilização de processos informáticos tem assegurado alguma objetivdade (a possível) na classificação das propostas.

[143 - música, teve apoio]

G Descentralização e internacionalização. Desenvolvimento de projectos artísticos relevantes.

[109 - música, teve apoio]

\section{Aspetos negativos}

46 a falta de clareza estratégica, dada a contingência e os limites orçamentais, é importante estabelecer prioridades e planos que definam claramente a ordem das prioridades. Não temáticas para a criação, mas planos de desenvolvimento da área da cultura que possam orientar também o sector em termos de escolhas estratégicas a médio e longo prazo.

[490 - artes plásticas, teve apoio]

64 Anúncio da data de abertura de concursos e apresentação dos formulários de candidatura com a devida antecedência para as estruturas poderem preparar- 
se para responder devidamente às exigências. exemplo: fixar anualmente as datas dos concursos Abertura de concursos em data que permita acomodar os prazos necessários entre a avaliação e a chegada do financiamento às estruturas Formulário de candidatura adaptado às condições reais, não de uma sociedade comercial, mas de uma estrutura cultural que age segundo uma óptica de prossecução de serviço público exemplo: concurso relativo aos apoios 20132017, em que o formulário parecia decalcado de um plano de marketing de uma sociedade comercial Investimento público / sustentabilidade das estruturas Não pondo em causa a existência dos concursos, sugerimos a existência de mecanismos que assegurem que o continuado investimento público numa estrutura não possa ser totalmente posto em causa por uma subjetividade inerente à avaliação das candidaturas. exemplo: nos concursos utilizar um critério de avaliação relativo ao histórico da estrutura Comissões de avaliação e acompanhamento: fornecer às estruturas cópia dos relatórios de avaliação da comissão de acompanhamento de modo a não funcionarem apenas como mecanismo de controlo, para a DGArtes, mas também de elemento de percepção de como a programação/criação desenvolvida é valorizada pelos técnicos e posterior direito de resposta ou correção de aspectos negativos, por parte das estruturas. Reformulação da plataforma electrónica, que parece adaptada às características de uma estrutura de teatro, não acompanhando as especificidades das outras áreas artísticas, nomeadamente as artes plásticas Implementação de um sistema que interligue a plataforma electrónica com as comissões de avaliação prevenindo a duplicação de tarefas Aligeirar os processos de pedidos de alterações nas atividades, o que poderá reduzir substancialmente o trabalho administrativo da DGArtes e os prazos de resposta exemplo: quando chega a resposta da DGArtes, as atividades alteradas já se encontram desenvolvidas ou em desenvolvimento Prazo de entrega dos relatórios anuais de contas e de atividades: mudança de 15 para 30 de Abril, pois há estruturas que terminam as actividades anuais até 30 de Março Internacionalização Possibilidade de as candidaturas de pessoas de pessoas singulares, em sede de contratualização poderem nomear uma entidade colectiva para celebrar o contrato Sobrevalorização das estratégias de comunicação Sobrevalorização dos públicos Sobrevalorização da circulação nacional

[462 - artes plásticas, teve apoio]

46

Os apoios têm privilegiado estruturas / entidades já consolidadas e que, habitualmente, já beneficiam de outros contactos, apoios, mecenas. Não é do conhecimento público quem integra as comissões de apreciação, nem os respectivos currículos. Não existe um guião de avaliação com critérios e factores de ponderação claramente definidos.

[25 - arquitetura, concorreu mas nunca teve apoio]

6

Tudo o que desvia a DGArtes da sua função matricial de apoio à criação artística contemporânea. Relação coma autarquias, território, com outros sectores... falta de transparência, falta de acesso aos processos, de justiça nas avaliações, de idoneidade e irresponsabilidade dos júris, falta de critérios e parâmetros 
claros, simples, alinhados com o que é pedido na instrução dos projectos, falta de justificações completas.

[299 - arquitetura, concorreu mas nunca teve apoio]

66 Burocracia. Valorização de projectos 'conhecidos' e entidades 'consagradas'. Inexistência de programas 'contínuos'. Atraso no lançamento dos programas de apoio.

[34 - arquitetura, concorreu mas nunca teve apoio]

66 Nem sempre se entende a pontuação das avaliações. Por vezes as perguntas na candidatura são pouco claras e repetitivas. Muito pouco espaço para as respostas. Possibilidade de alteração da calendarização, orçamento, etc.

[331 - arquitetura, teve apoio]

G Tempo de resposta na avaliação das candidaturas Não divisão de processo de candidatura por tipologia de projectos As quotas por área artística nos apoios directos A falta de comunicação de um calendário de apoios com antecedência que permitisse às entidades planear uma estratágia de financiamento.

[205 - artes digitais, teve apoio]

G6 Não ter em conta a especificidade das áreas, a diferença entre criadores plásticos e estruturas de áreas como o teatro e dança.

[508 - artes digitais, teve apoio]

6 O interface em geral nao é convidativo a ser utilizado. Pensamos que poderia ser muito melhor ao nivel de leitura e de criar habitos nas estruturas. É uma ferramenta precisosa que pode ajudar todos. No entanto por vezes torna se dificil de leitura e compreençao lógica. É obvio que quem fez o design do interface nao trabalha com estruturas de cultura e de analise destas. Um help desk pode ser uma das soluçoes mas mais uma vez isso é tapar um buraco e nao ir a questao de fundo. Nao ter avisos imediatos quando se ultrapassa os prazos de entrega sao as qustoes que podem ser melhoradas. No fundo o interface geral pode ser melhorado.

[208 - artes plásticas, nunca concorreu]

66 Processo de candidatura complexo. Muito desequilíbrio em termos de montantes de apoio. Poucos escalões de apoio: deveria haver escalões com montantes mais reduzidos (por exemplo de 5.000,00€; 8.000,00€; 10.000,00€; $15.000,00 € ; 20.000,00 € ; 25.000,00 €$ e $30.000,00 €$. Deveria haver apoio a projectos e apoio a plano de actividades Épocas de candidaturas com datas fixas. 
Estabilidade na plataforma de candidatura. Entregar documentos após aprovação de candidatura.

[270 - artes plásticas, teve apoio]

66 Os aspetos negativos são sobretudo a falta de apoio, a indefinição de critérios de atribuição dos apoios, o atraso nas tranches de pagamento, vindo muitas vezes já no final do programa, a relação de forças entre regiões bastante desequilibrada, a falta de sustentabilidade do modelo de apoio.

[369 - artes plásticas, teve apoio]

6 Enviesamento das comissões de avaliação Competição entre áreas dificilmente comparáveis (por exemplo, teatro versus design) Em muitos concursos áreas periféricas são prejudicadas (por exemplo, publico no Alentejo será sempre menor que em Lisboa)

[144 - artes plásticas, teve apoio]

66 - As modalidades de pagamento das tranches dos valores a transferir a cada entidade têm sido alteradas e os prazos nem sempre cumpridos com todo o rigor; - As entidades não devem ser interdependentes quanto ao cumprimento das suas obrigações, no que respe

[445 - artes plásticas, teve apoio]

6 Prazo de candidatura demasiado curto Comunicação de abertura com pouca antecedência Demora nas transferências dos apoios concedidos Processo muito burocrático

[269 - artes plásticas, teve apoio]

66 Não contemplar a produção de cinema independente de baixo orçamento nem (que eu saiba, espero estar enganado) o pagamento dos autores de videoarte e cinema experimental permitindo assim que este seja divulgado por iniciativas independentes.

[196 - outra área, nunca concorreu]

$6 \mathbf{f}$ calendarização programas mais ajustados às áreas performativas e muito pouco às outras...

[179 - outra área, teve apoio]

6 Falta de regularidade no calendário de concursos; Processos demasiados longos (desde que abre até que sai o resultado e se recebe o dinheiro); Timing de 
candidatura diferente do circuito profissional; Complexidade das candidaturas (demasiada informação artística e de gestão); Excesso de formalidade nos concursos (apenas escrita, faltam meios complementares e presenciais); Falta de faseamento no processo (ideia, desenvolvimento, apoios, circulação); Distância física do organismo e dos seus interlocutores; Existência de estruturas financiadas cujo impacto do seu trabalho levanta dúvidas na sociedade atual levando a uma desconfiança sobre o sistema e um impedimento para a renovação de tecidos; Disparidade de valores nos apoios concedidos a diferentes estruturas com trabalhos idênticos, em duração, equipas e pertinência;

[70 - outra área, teve apoio]

66 Não haver uma apresentação da candidatura em pessoa, ou uma visita à estrutura por parte da DGArtes. Todos as entidades serem avaliadas da mesma forma, sejam elas estruturas de criação ou de programação. Obter ou não o apoio ser mais uma questão política e de interesses do que pela mais valia da proposta. Formulários extremamente complicados.

[235 - cruzamentos disciplinares, teve apoio]

66 Aspetos negativos: desrespeito total pela classe artística e pelos compromissos políticos assumidos... Comparar o incomparável. Burocratizar, centralizar informação e decisões sem a reflexão e diálogos permanentes com as estruturas apoiadas. Falta de explicitação das linhas de política cultural efetivas e inteligíveis. Enunciar medidas avulsas de apoios, pensando que é num regulamento que está contida a execução política de um Ministério. O poder político ter esvaziado o papel relevante do $\mathrm{MC}$, não só pelo excluir do estatuto ministerial, como no transmitir uma imagem pública da política cultural desinteressante e supérflua. Falta de conhecimento da realidade do setor cultural e artístico, confinando a atuação à justificação da exiguidade da verba disponível para apoio às artes e a um desinteresse no traçar de objetivos para o setor. Falta de conhecimento, desinteresse e falta de entusiasmo e ousadia. Júris fantasmas. Critérios pouco transparentes. Em suma, inexistência de política cultural e anos perdidos de marasmo na gestão do caos que a falta de paixão provoca. (Esta caraterização, suportada por frases acutilantes e pouco explicativas não pretende criticar gratuitamente um modelo, um governo ou uma época restrita, mas a ausência de uma política cultural que seja percecionada de forma global pelos agentes culturais e artísticos e pelos cidadãos).

[260 - cruzamentos disciplinares, teve apoio]

66 Excessiva burocratização dos processos. Subfinanciamento Incoerência dos objectivos de política cultural definidos com os resultados Falta de trabalho conjunto Desvalorização da comissão de acompanhamento. Deve ter mais elementos e funcionar regularmente, fazendo a ponte entre os objectivos e metas dos projectos apoiados e os resultados artísticos e de gestão. A plataforma e o 
seu funcionamento em geral A excessiva compartimentação dos projectos que dificulta o enquadramento de muitos projectos

[244 - cruzamentos disciplinares, teve apoio]

66 Consideramos que os calendários para apresentação de candidaturas / resultados são muitas vezes desfasados face às necessidades dos artistas e agentes culturais, e ao respectivo período de realização de projectos.

[305 - cruzamentos disciplinares, teve apoio]

66 - avaliação demasiadamente do âmbito formal (muita relevância dada a parcerias e orçamento) em detrimento da avaliação do conteúdo artístico; - pouca sensibilidade a nível de critérios de avaliação que beneficiem os artistas emergentes; - Pouca sensibilidade às dificuldades dos artistas/estruturas emergentes em conseguir, perante a situação adversa no sector cultural, co-produtores, parcerias e locais de circulação, que face ao modelo de apoio actual nos penaliza fortemente no concurso.

[489 - cruzamentos disciplinares, teve apoio]

6 A falta de um modelo de financiamento específico para a programação regular de teatros, como atividade preponderante. A complexidade dos formulários dos planos de atividade e orçamento, decorrente do detalhe exigido. Os prazos de lançamento dos concursos, normalmente tardios em relação às datas de início das atividades.

[413 - cruzamentos disciplinares, teve apoio]

66 Concentração de apoios em entidades com trabalho que não corresponde a uma relação positiva com o território, nem com as alterações dos processos de criação e programação.

[303 - cruzamentos disciplinares, concorreu mas nunca teve apoio]

66 - Misturar todas as áreas expressivas num só concurso (excepção feita ao cinema). - As verbas serem quase sempre todas concentradas na mesma região. - Não haver concursos de âmbito regional. - Carga burocrática muito pesada.

[289 - cruzamentos disciplinares, teve apoio]

6 As datas quase sempre incertas em que são abertos os concursos. A ausência de conhecimento público dos membros que constituem os júris independentemente dos concursos.

[361 - cruzamentos disciplinares, teve apoio] 
G6 É um modelo desajustado à realidade presente e que menospreza a ascensão futura das artes. Coloca em pé de igualdade projetos que se revelam completamente distintos na sua essência, e que por isso nunca poderão ser compreendidos num modelo único ou inflexível. O novo modelo de apoio deverá possuir um corpo comum que deverá adaptar cada área de atividade a um campo de intervenção/trabalho adequando cada projeto ao devido tipo de apoio e o mesmo à natureza dos seus objectivos.

[478 - cruzamentos disciplinares, concorreu mas nunca teve apoio]

6 Existem de facto mais aspectos negativos do que positivos no que diz respeito ao actual modelo de apoio às artes. Um desfasamento na distribuição dos apoios e avaliação das candidaturas, uma percentagem orçamental esganada no que remete ao orçamento de estado para as artes, uma péssima e insuficiente valoração das estruturas e dos agentes independentes, um suporte e apoio deficiente no que diz respeito aos contratos de trabalho e à manutenção dos agentes culturais ainda activos, um descrédito destes a longo prazo em relação à própria profissão, um interesse por parte das comissões de acompanhamento e respresentantes governamentais deficitária que de modo algum não consolida qualquer continuidade neste sector colocando-o sempre em constante flutuação. A inconformidade de implementar um sistema de apoio às artes que abrange e permite que estruturas $\backslash$ agentes culturais tão diferenciados sejam avaliadas à luz dos mesmos critérios e patamares.

[514 - cruzamentos disciplinares, teve apoio]

6 Demasiado burocrático, e financeiro. Existir um tema é um factor descriminatorio. Tem muitas alíneas que se adequam para extruturas e não para singulares. Não se pode inserir espaços entre parágrafos, ou escolher a letra em bold ou itálico

[257 - dança, teve apoio]

66 - O aspeto mais negativo não tem a ver com o modelo, mas sim com a certeza da insuficiência de verbas, isto é, os valores existentes para a cultura e, consequentemente para os apoios, são insuficientes à prática artística. - A inconstante calendarização,

[345 - dança, teve apoio]

66 Nos apoios pontuais, jovens artistas e artistas com muitos anos de experiência concorrem ao mesmo apoio sem qualquer discriminação positiva. Os processos de candidatura são demasiados complexos e, sobretudo, desajustados da realidade precária tanto em termos financeiros como de meio de produção. Os 
prazos de abertura e encerramento da candidatura são repentinos e não permitem a devida preparação da candidatura. (Os últimos apoios pontuais abriram no Verão quando as estruturas e os agentes culturais estão de férias).

[471 - dança, teve apoio]

46

- nao acessível a todos mas apenas a pessoas já experientes com o próprio modelo e linguagem técnica a utilizar - anuncio de abertura tardio, calendarização pouco rigorosa - conflitos entre especificidades dos projectos e planilha electrónica obrigatória

[523 - dança, nunca concorreu]

6

Verba deficitária Critérios de avaliação nem sempre adequados a cada tipologia de concurso Factores de majoração que subvertem as propostas/ inadequados Critério de razoabilidade pouco transparente Apoios indiretos - acordos tripartidos Plataforma pouco ágil Burocracia (penaliza o sector e a DGArtes)

[376 - dança, teve apoio]

6 Orçamentos muito abaixo do necessário Calendários e pagamentos tardios ou desajustados das necessidades Pouca capacidade reivindicativa junto à tutela Não existir um relação direta e consequente entre estruturas e projectos apoiados e circulação na rede de teatros

[117 - dança, teve apoio]

661 - a não existência de juri nos concursos pontuais 2- a não obrigatoriedade no que diz respeito a candidaturas que não apresentam cartas de estruturas de acolhimento e apresentação com valores monetários explicitos, permitindo ao candidato colocar qualquer valor. 3- as modalidades artísticas em conjunto, quando as artes performativas têm necessidades e características completamente distintas das artes digitais, por exemplo 4- apenas haver um concurso de apoio pontual por ano 5- os concursos abrirem nas férias dos teatros e programadores

[430 - dança, teve apoio]

G6 Complexidade burocracia dificuldade opacidade pouco confiável pouco democrático

[85 - dança, teve apoio] 
66 - A não definição de datas específicas para abertura de concursos; - O não cumprimento dos tempos de resposta legais durante o processo de concurso e respectivo procedimento contratual; - Factores de majoração deviam ser reavaliados; - Projecto de gestão

[294 - dança, teve apoio]

66 Sub-financiamento prolongado; excesso de burocracia; desacompanhamento por parte das entidades que financiam; demasiado peso da parte administrativa na avaliação das propostas (em detrimento dos conteúdos artísticos); desvalorização dos currículos de artistas e estruturas; desarticulação com outras políticas sectoriais; lógica de desresponsabilização do Estado; valorização da "sustentabilidade económica" de projectos e estruturas; desvalorização da importância das estruturas de criação e programação artística; insuficiente defesa e clarificação do lugar do profissionalismo no trabalho artístico.

$$
\text { [498 - teatro, teve apoio] }
$$

66 Não tem como critério a quantidade de espectadores a que os projectos apoiados chegam. Há uma incómoda sensação de que são sempre os mesmos a beneficiar dos apoios.

$$
\text { [401 - teatro, concorreu mas nunca teve apoio] }
$$

66

indefiniçao dos concursos na sua periodicidade, o desfazamento entre o incio do ano civil e o inicio determinado pela abertura dos concursos. O desfazamento desproporcional entre o orçamento apresentado na candidatura e o montante atribuido. $O$ valor disponivel para os apoios da dgartes não é proporcional ao $\mathrm{n}$ o de estruturas e projectos concorrentes. montante global e a sua distribuição. Consideramos injusto um criterio de majoração que tem acontecido nos ultimos concursos em que todas as estruturas não pertencentes ao do concelho de Lisboa partem emvantagem para o mesmo. Consideramos demagogico o chamado conceito de descentralização e de internacionalização.

[456 - teatro, teve apoio]

6

1. A limitação de uma Autarquia por Apoio Tripartido. Essa limitação, no nosso entender deve ser apenas estendida às estruturas de criação e produção artística. 2. O Factor de Majoração "Exercício da(s) atividade(s) maioritariamente fora do concelho de Lisboa" contendo em si um princípio de discriminação positiva, parece-nos negativo ter como referência unicamente a actividade desenvolvida fora do Concelho de Lisboa. No nosso entender este factor deve contemplar uma majoração dos projectos inseridos nos centros/zonas geográficas com os índices de desenvolvimento mais reduzidos de acordo com a informação da própria Administração Central. Atribuindo uma pontuação diferenciada para os diferentes índices de desenvolvimento, mais alta para os me- 
nos desenvolvidos. Assim, sugerimos a alteração do factor para "Índice de desenvolvimento geográfico". Acrescentamos que este factor de majoração deverá ser mais representativo do que é actualmente, e ter uma ligação compensatória relativa aos critérios e parâmetros de apreciação "Capacidade de gerar receitas próprias e outras fontes de rendimento". 3. É também negativo valorizar e pontuar de igual modo os diferentes Factores de Majoração, tendo em conta as suas diferenças e relevância no cumprimento dos enunciados do Decreto-Lei, da Portaria e dos princípios gerais do próprio concurso.

[494 - teatro, teve apoio]

6 m dos aspetos negativo é a entidade não conseguir cumprir com os critérios exigidos pela tutela (exemplo, circulação, descentralização,..) O não reconhecimento do trabalho artístico desenvolvido com as comunidades locais. A falta de adequação dos critérios a realidade das diferentes regiões. A parte administrativa e financeira requer uma estrutura administrativa e financeira da entidade muito organizada para determinadas modalidades.

[448 - teatro, concorreu mas nunca teve apoio]

6 Elevada centralização dos projetos apoiados nas áreas de Lisboa e Vale do Tejo. Não participação das DRCs em todas as modalidades de apoio. Baixo orçamento disponível para os apoios às artes. Não consideração dos apoios que garantam condições profissionais regulares às estruturas e criadores.

[10 - teatro, teve apoio]

6 Contribui para a discriminação negativa de agentes culturais com créditos firmados; baseia-se numa lógica igualitária e não de equidade, distribuindo pouco por todos, sem outro critério que não seja o de assegurar que o Estado cumpriu a sua obrigação perante os agentes culturais; promove, mesmo que inadvertidamente, uma divisão e discriminação claras entre as estruturas apoiadas e não apoiadas, numa espécie de lamentável «primeira e segunda divisão das artes»;

[506 - teatro, teve apoio]

66 Os aspetos negativos do atual modelo de apoio às artes prendem-se com aspetos práticos da aplicação do modelo e com aspetos programáticos. No que diz respeitos à aplicação prática do modelo, é de referir: a calendarização dos concursos, que, por ser desadequada e não ser previamente anunciada, cria não só instabilidade nas estruturas e precaridade laboral, como inviabiliza e prejudica alguns projetos; a complexidade excessiva das candidaturas, sobretudo em alguns aspetos do orçamento, agenda e comunicação que referimos em Q19; os fatores de majoração, que foram úteis num dado momento, mas que devem ser avaliados de acordo com os critérios de avaliação pré-estabelecidos, com a natureza e especificidade de cada projeto e com uma ideia de 
Serviço Público; a fórmula que determina o montante a atribuir, por ser constituída por fatores ambíguos como o "fator de razoabilidade" e o "montante solicitado"; o não "cumprimento" por parte do júri de alguns critérios de avaliação, talvez porque seja necessário clarificá-los e garantir que são considerados no momento de decisão (como inscrição no tecido cultural e no território, inovação, formação de públicos, parcerias, serviços educativos, organização interna de um programa coerente, etc.). Relativamente às questões programáticas é necessário, do nosso ponto de vista, definir e esclarecer quem pode concorrer a que tipo de apoios, não colocando num mesmo concurso estruturas como Teatro Municipais ou similares e estruturas Independentes, com fragilidades e necessidades criativas, orçamentais e organizacionais mais prementes; por outro lado, é também necessário definir o que são, e a quem se destinam, os apoios plurianuais e estruturantes, e o que são e a quem se destinam os apoios pontuais ou outros. Nesta clarificação deve entender-se que um projeto plurianual tem de ser mais do que um conjunto de projetos pontuais, daí ser importante definir critérios de avaliação e analisar cada candidatura como um todo orgânico. É também necessário ponderar o peso dado às coproduções com entidades que detêm já uma grande parte dos recursos financeiros do Estado, uma vez que o estabelecimento dessas parcerias obedece a critérios de exceção, nos quais nem todos os artistas e criadores têm voz ativa. No que se refere a outras linhas de apoio, julgamos importante considerar o apoio: à edição, uma vez que, no caso das Artes Performativas, pode constituir um fator fundamental no reconhecimento e fixação de uma memória partilhável e transmissível sobre o trabalho realizado; à aquisição de material técnico, do qual beneficiaria um conjunto de entidades e criadores; a bolsas de formação para profissionais, permitindo uma melhoria das práticas artísticas, de produção e de gestão. Um outro aspeto que nos parece da maior relevância é a articulação com o poder local, nomeadamente através da rede de cineteatros. A não existência de uma rede organizada inviabiliza o tão desejável incentivo à circulação nacional. Um caderno de encargos bem definido, bem como a criação de uma bolsa para projetos apoiados que visasse apoiar algumas despesas de cachet, poderia ser um motor importante para existir mais e melhor circulação, de projetos diversificados, validados por um júri. Um outro ponto menos positivo prende-se com o funcionamento das Comissões de Acompanhamento e Avaliação. Nem todas as Comissões funcionam efetivamente, e os resultados produzidos pelas Comissões não são comunicados e discutidos com todas as entidades, no sentido de melhorar as práticas das mesmas. Por último diríamos que é necessário que nas candidaturas sejam privilegiados como fatores de avaliação não apenas os aspetos tangíveis e passíveis de ser transformados em números, mas também os aspetos intangíveis, que são verdadeiramente transformadores e justificam a existência de apoios à atividade artística (como a relação com os públicos, a inscrição no território, o sentido de pertença, o espaço de fórum agregativo de encontro e debate, a possibilidade de nos emocionarmos e comovermos...) Neste sentido, a DGArtes é um organismo fundamental na relação entre criadores e Estado, contribuindo para o cumprimento dos valores defendidos na Constituição Portuguesa, nomeadamente nos artigos 9o, 42 ㅇ, 73 ㅇ e 78 o, pelo que tem de ser valorizada e fortalecida.

[273 - teatro, teve apoio] 


\section{Outros aspetos}

A questão final do questionário solicita contributos sobre quaisquer outros aspetos considerados relevantes e que não foram antes colocados ou explicita$\operatorname{dos}^{51}$. Para uma parte significativa da amostra (mais de metade) não houve lugar a qualquer novo contributo. Entre as entidades que responderam predominam as que tiveram apoio pelo menos uma vez (62\%), sendo que as que nunca concorreram e as que concorreram mas nunca tiveram apoio repartem a percentagem em falta ( $19 \%$ cada).

Entre aquelas que optaram por responder a esta questão, uma parte reforçou temas já antes tratados nas várias questões, aproveitando para reafirmar aqui alguns dos seus principais argumentos. Outras entidades optaram por inserir documentos já enviados à tutela ou já publicados, ou pelo menos referidos como tal. Mas estão também patentes preocupações, propostas e outros aspetos antes não explicitados/questionados e relacionados com o modelo de apoio financeiro às artes, designadamente quanto à defesa de uma maior atenção aos criadores individuais, e em particular aos emergentes. E também outros aspetos não diretamente relacionados com os enquadramentos do modelo de apoio às artes.

Um desses aspetos é o enquadramento dos teatros e cineteatros (municipais) no modelo de apoio. Outro refere-se aos processos de auscultação e de participação do sector, em geral, e o presente EPEA, em particular, que motivaram, em diversos sentidos, inúmeros contributos, geralmente positivos. Mas quanto ao estudo várias entidades manifestam reservas, desacordo ou colocam dúvidas e interrogações. Outros destacam, a propósito ou não do estudo, a importância de realização de estudos sobre o modelo de apoio (de avaliação) e sobre o sector, identificando algumas, inclusivamente, as linhas que haverá que desenvolver com vista a um melhor conhecimento do sector, conhecimento importante para as próprias entidades, mas também para informar o desenho das políticas públicas.

\footnotetext{
${ }^{51}$ Q37. O questionário está a terminar. Queira por favor acrescentar algum aspeto sobre o apoio às artes que não tenha sido antes abordado. A taxa de resposta é $43 \%$, sendo que mais $5 \%$ responderam não ter nada a acrescentar.
} 


\section{Os teatros e cineteatros, os programas de redes de equipamentos de artes do espetáculo de parcerias central/locais}

6

1. A questão do funcionamento dos Cine-Teatros: Consideramos que o passo estruturante mais importante a dar no âmbito do apoio às artes é a criação de uma linha de apoio para os teatros e os Cine-Teatros portugueses, pondo-os verdadeiramente ao serviço da criação, da fruição da cultura e da valorização do território. No modelo de concurso vigente, a oferta cultural e a procura cultural, aparecem, como fazendo parte do mesmo concurso, algo de anacrónico. Por exemplo, não faz nenhum sentido, numa determinada região, um teatro concorrer contra uma estrutura de criação, visto não serem concorrentes, estando no espectro oposto da relação cultural (em termos muito simples, um compra e o outro vende...). [...]. Na nossa opinião, o sistema ideal, seria um sistema misto. Por um lado, com uma linha de apoio como a actual, para os criadores, agentes e estruturas independentes de apoio à criação, melhorada (e, neste sentido, consideramos este inquérito muito pertinente), dentro dos princípios actuais, e baseada nos contratos-programa. Por outro lado, uma linha de apoio para os teatros municipais, que valorizasse as boas práticas de programação, a criação, a co-produção e facilitasse a circulação de obras anteriormente apoiadas pela DGArtes, colocando os cine-teatros no coração do tecido local.

[418 - cruzamentos disciplinares, teve apoio]

66 Este questionário não aborda alguns assuntos absolutamente prioritários: 1. o abandono da rede de teatros municipais que necessita de uma política urgente e concertada que povoe estes equipamentos com equipas funcionais de técnicos, produtores e programadores, tornando estes equipamentos públicos a base de uma rede activa de apoio à circulação de espectaculos e outras iniciativas artísticas. 2. o ensino artístico e técnico das artes performativas que perdeu a conexão com o Ministério da Cultura.

[49 - outra área, teve apoio]

\section{Sobre o Estudo Posicionamentos das Entidades Artísticas}

Sobre o EPEA, é reconhecida a sua relevância enquanto modo de auscultação do sector e de participação na construção de um novo modelo, são apontadas as virtualidades mas também as limitações, são identificados aspetos não considerados no inquérito, feitas propostas com vista a manter e melhorar processos participativos no âmbito do apoio financeiro às artes. E são também colocadas questões sobre a utilidade do estudo, a forma como os resultados serão (ou não) divulgados e devolvidos às entidades que nele participaram. 
66 Obrigado pela possibilidade de diálogo e pelo desafio de realizar um estudo participativo. Parabéns pela iniciativa.

[486 - outra área, nunca concorreu]

66 Os meus sinceros parabéns por toda esta iniciativa. Estou pessoalmente disponível para apoiar, assistir, dar ideias construtivas, sobretudo no plano da internacionalização [...]. Contem comigo!

[194 - música, concorreu mas nunca teve apoio ]

66 iniciativas como esta, de auscultação das entidades, são essenciais. Criam um clima de entreajuda, aproximam-nos na missão de serviço público. Serão de continuar

[115 - teatro, concorreu mas nunca teve apoio]

66 Este processo de auscultação ao setor é muito positivo e deveria ser uma prática regular, de modo a harmonizar as relações no meio cultural e a tornar as entidades públicas e os concursos mais próximos da realidade do panorama nacional do setor artístico.

[502 - teatro, concorreu mas nunca teve apoio]

66 É importante ter uma plataforma de avaliação aos apoios aberta onde as entidades apoiadas e não apoiadas possam avaliar ou dar sugestões para próximas candidaturas.

[210 - música, teve apoio]

66 Estamos satisfeitos por este questionário, gostaríamos de continuar neste diálogo e que a DGArtes e o Ministério da Cultura se consolidem em iniciativas e dinâmicas que sejam projetadas a longo prazo.

[170 - teatro, teve apoio]

66 Acho que é louvável esta iniciativa de inquérito. Mas ainda não é uma iniciativa verdadeiramente corajosa. Acho que há uma enorme desproporção entre espaços culturais e a sua qualidade e os artistas que (não) os usam. Devia haver uma grande rede de pequenos espaços e não uma pequena rede de edifícios luxuosos que não cabem e não têm cabimento na cidade. Devia haver um apoio à circulação nacional. Para mim seria mais importante do que a internacional.

[73 - teatro, concorreu mas nunca teve apoio] 
6 Na quantidade e dispersão das questões, o presente questionário é sintomático de um dos grandes problemas do "apoio às artes", a perda do enfoque na criação contemporânea, que por fim desemboca numa miríade de questões. A opção por consultar o sector desta forma, através de um questionário, é legítima mas pouco ambiciosa. Desejando-se tornar o sector participante de uma nova política para o sector, porque não desenvolver um processo participativo de construção desta mesma política? Agradece-se a possibilidade de tomar a palavra - fazendo contudo votos de que esta palavra tenha melhor tratamento que o standard DGArtes -, não podemos deixar de referir que a ambição em termos de participação do sector é incipiente. Neste quadro e para terminar, ocorre perguntar o que é que a equipa deste estudo apresentará ao encomendado, e se o facultará aos participantes? E quando, a uns e a outros?

[408 - dança, teve apoio]

66 Este questionário não aborda uma dimensão fundamental que é: "para que é que servem os apoios Às artes". Parte do princípio - errado a meu ver - que os apoios servem para os criadores criarem e para os programadores programarem. Mas há outros modelos e outras concepções sobre os apoios que não estão a ser consideradas, como por exemplo o facto de o estado não dever apoiar criadores mas sim o acesso à criação.

[123 - design, concorreu mas nunca teve apoio]

G6

Como já referido: - um estudo ao posicionamento do sector em relação ao quadro institucional, legal, etc, deverá passar por análise de amostras capazes das interacções entre sector e administração (pronúncias, reclamações... e respostas administrativas), pois parece-nos curto as meras opiniões expressas em inquérito; - mais interessante, mobilizador, responsabilizado seria encetar a revisão do modelo de apoio às artes de forma participada.

[515 - cruzamentos disciplinares, teve apoio]

66 Abordados todos os aspectos que considero pertinentes para o auxilio da criação de um novo modelo de apoio às artes, aproveito este espaço para louvar esta iniciativa de auscultação das entidades envolvidas com a DGArtes. Igualmente quero deixar expresso o meu agradecimento por poder expressar a minha opinião com base na experiência que reúno, a qual espero que possa ser auxiliante. Obrigado.

[478 - cruzamentos disciplinares, concorreu mas nunca teve apoio]

6

Ficaram certamente coisas por dizer. Este questionário é pertinente, contudo extremamente complexo e exigente, por vezes de difícil resposta objectiva e que pressupõe bastante trabalho, tempo e reflexão. A criação artística é dinâmicas, pelo que pressupõe uma constante reavaliação e enquadramento. Uma 
análise e dialogo continuado é fundamental para seguir a par as mudanças e contingências da arte.

[294 - dança, teve apoio]

66 Agradeço a iniciativa e a tentativa de consultar o setor e de sistematizar a informação recolhida - só por si, representa um importante passo. É importante reconhecer que este tipo de estudo se baseia em percentagens, pelo que o numero de respostas e a qualidade das mesmas é muito importante para aferir resultados.

[479 - dança, teve apoio]

Resta acrescentar o mérito deste inquérito e esperar que não se vá juntar aos demais estudos, levantamentos e inquéritos já realizados ao longo dos últimos 30 anos. Tudo está visto e revisto, e comparado com outros modelos internacionais Há 3 décadas de números e estatísticas, e pouco se tem aproveitado. Há uma constante: está-se sempre a mudar. De ministro, de regras, de organigramas, etc., etc., etc. Mais uma vez se vai mudar, e mesmo com as análises científicas que poderão sair deste inquérito, permanecerá certamente uma incapacidade de melhorar o quadro legal. Sabe-se o que se tem de fazer para organizar um sistema funcional de financiamentos, estável e coeso. Mas, para isso seria necessário uma perspetiva de médio prazo. $\mathrm{E}$ isso...

[175 - teatro, teve apoio]

6 Estive presente na sessão de esclarecimento e pareceu-me despropositado o tempo que ocuparam os discursos e a demonstração em powerpoint deste questionário, dando às entidades muito pouco tempo para exporem as suas dúvidas, questões e sugestões. Uma sessão de esclarecimento deveria ser realmente para ouvir o que as entidades têm para dizer, e este questionário parece-me insuficiente, as questões que se colocam parecem-me pouco relevantes comparativamente às questões que realmente parecem inquietar o sector artístico do país. Acho que negligenciam, como sempre, os artistas, continuando a dar prioridade aos grupos, às estruturas, às associações, às pessoas que têm outro tipo de condições e modos de funcionamento. Este questionário parece-me mais uma forma de diplomacia, do que uma verdadeira solução para ouvir o sector.

$$
\text { [206 - dança, teve apoio] }
$$

Todas estas questões, de enorme pertinência, apresentadas no presente questionário, só farão realmente sentido debater e projectar na medida em que o Estado se comprometa com um efectivo apoio material ao sector das artes. A maior parte das questões e o debate à sua volta, tornam-se estéreis se não houver correspondente investimento financeiro (desde logo, mas não só) nos programas de apoio. A dotação orçamental em curso para o sector, e a dos 
últimos anos, não é compatível com um diálogo sério da tutela com o sector. Para além disso, em termos processuais, a DGArtes tem sido uma entidade imprevisível e incumpridora, nomeadamente nos prazos para lançamento de concursos) e na contratualização com as estruturas /criadores apoiados. A imprevisibilidade prejudica fatalmente o funcionamento e a sustentação das estruturas. Os concursos devem ter em conta uma maior antecedência para a preparação das propostas e sua submissão nas plataformas. Há uma desaquação entre os prazos necessários para a definição dum plano de actividades execuível (e financeiramente viável), e as garantias dessa viabilidade dadas na obtenção do apoio.

[371 - teatro, teve apoio]

66 Gostaríamos de saber se os resultados do inquérito vão ser apresentados publicamente, e como vão ser tidos em conta numa eventual alteração dos modos de apoio.

[157 - cruzamentos disciplinares, nunca concorreu]

G6 Não temos nada a acrescentar, apenas que desejamos que estes contributos sejam traduzidos em medidas concretas.

[510 - cruzamentos disciplinares, concorreu mas nunca teve apoio]

6 Deixamos questões: Os resultados deste questionário vão ser debatidos? Como vão ser divulgadas as decisões que vão ser tomadas a partir deste contributo?

[265 - dança, teve apoio]

66 O próprio questionário; (como está e como são as perguntas) reflicta apenas o aspecto administrativo e burocrático das DGArtes em relação as necessidades de artistas. Tenho duvidas que com este questionário se vai mudar a situação em qual se encontram todos os diferentes sectores das artes. Por que não muda nada no sentido de descentralizar os mecanismos de decisões. Para meIhorar a situação nas artes em geral seria necessário de por nas mãos dos teatros e entidades de produção, que entendem os assuntos e projectos dos artistas, o poder de decisão e não manter em mãos de incompetentes júris e mecanismos como existem actualmente.

[184 - música, nunca concorreu]

6 Obrigado aos investigadores do ISCTE pela vossa colaboração. A abordagem científica a estas questões é fundamental para um melhor entendimento entre as partes.

[521 - música, teve apoio] 
66 Gostaria de referir que para conhecer estas realidades os senhores consultores deviam deslocar-se 'ao terreno', ver, assistir e falar com quem trabalha nestes projetos e com os artistas. Congratulamo-nos com a iniciativa de melhorar este processo e pelo facto de querem a nossa participação. No entanto não podemos deixar de alertar que o envio deste tipo de inquéritos, demasiado longos e morosos, a pessoas que de um modo geral têm que compatibilizar as suas obrigações profissionais e familiares com o trabalho voluntário como agentes culturais, é uma metodologia que poderá não ser bem sucedida.

[232 - música, teve apoio]

66

Este questionário é péssimo.

[148 - teatro, concorreu mas nunca teve apoio]

66 Não podemos deixar de notar que o anonimato prometido neste inquérito fica fortemente comprometido pelo tipo de questões colocadas. Correndo o risco de estarmos enganados, somos capazes de afirmar [...] que permite uma identificação fácil de quem somos. Não o tentamos esconder, defendemos as respostas que damos, mas preferíamos que não nos tratassem com uma ligeireza desadequada ao nível ideológico e cultural das perguntas que nos são feitas.

[529 - teatro, teve apoio]

66 inquérito é uma iniciativa louvável. É, de facto, essencial proceder a alterações de fundo no que diz respeito ao apoio às artes. Reforçar os apoios e distinguir o papel e as funções dos agentes artísticos torna-se essencial para redesenhar a gestão das artes em Portugal, atendendo às novas realidades que se impõem diariamente a artistas, gestores, programadores, e equipas. É um trabalho difícil e longo, mas necessário para equiparar o nosso sistema de apoio às artes a outras realidades internacionais e para tornar o quotidiano dos agentes do sector mais ágil e lógico.

[240 - teatro, teve apoio]

61 - Critérios de apreciação vagos como o "fator razoabilidade" do art 7-1-e da portaria 1189-A/2010 não deveriam ser admissíveis num Estado de Direito, a menos que fossem de algum modo concretizados e escalonados (como por exemplo se faz no número 3 do mesmo artigo para o critério da alínea d). 2 Seria importante que a atividade do CIES/IUL só terminasse no final do processo legislativo para que fosse possível avaliar a relação entre os resultados do inquérito e as opções normativas. Para sindicar que a "auscultação do setor", que será invocada no preâmbulo do diploma, foi real e não apenas um simulacro de participação, organizado com a finalidade de validar um diploma já escrito. 
66 O questionário pode ser útil, mas mais importante tem que ser a posição do governo e o conhecimento do meio artístico que quer apoiar. Se toma essa decisão então os artistas têm que ser tratados em pé de igualdade, como parceiros, que infelizmente não é o que acontece. Também tem de evitar-se os discursos meio fascizantes do apoio a jovens. Não que estes se excluam, mas pergunto-me sempre o que faz a DGArtes em ralação a projectos de pessoas que têm várias décadas de carreira.É necessário que o tempo de exploração das peças seja de pelo menos um mês, como acontecia há uns anos. Seria bom pensar numa racionalização e multiplicação dos horários dos espaços de apresentação. Os teatros nacionais, como o nome indica, e já agora os municipais, devem ter obrigatoriamente uma programação plural e não a que reflicta apenas os gostos ou tendências dos directores artísticos, como vem sendo hábito desde há uns anos.

[195 - teatro, teve apoio]

\section{Programas e linhas a apoiar/considerar}

G6 Três importantes aspectos: Apoios mais imediatos, de menor valor e menos complexos para novos criadores. Parcerias e redes de circulação e difusão, nacionais e internacionais dos projectos apoiados.

[188 - cruzamentos disciplinares, teve apoio]

66 Seria importante a DGArtes apoiar financeiramente as estruturas que tenham já atingido um patamar de qualidade que lhes permite concorrer a apoios europeus para projetos vários, mas que precisariam de financiamento para adiantar pagamento de despesas na falta de capital de giro próprio, para poderem concorrer a apoios a fundo perdido, mas que funcionam apenas na base do reembolso de despesas comprovadamente realizadas... Eventualmente esse dinheiro voltaria para os cofres da DGArtes... para reciclagem em outros projetos, E a DGArtes, as Direções Regionais e mesmo as Câmaras Municipais, deveriam manter gabinetes que recolhessem e distribuíssem informação sistemática sobre essas oportunidades europeias (e não só) dando apoio técnico e orientação jurídica às estruturas na preparação dessas candidaturas, que é um apoio relevante e de valor incalculável, mesmo que não implique qualquer desembolso financeiro extra para as citadas organizações.

[162 - cruzamentos disciplinares, concorreu mas nunca teve apoio]

66 A questão do financiamento Europeu, e a forma de aceder. A necessidade constante que temos na produção de documentação, e o seu financiamento.

[295 - fotografia, nunca concorreu] 
66 Justificar-se- ia em caso pontuais a concessão de apoios para pesquisa e investigação nos campos subsumidos nos apoios.

$$
\text { [222 - dança, teve apoio] }
$$

66 do apoio financeiro às escolas de formação musical das sociedades filarmónicas.

$$
\text { [99 - música, concorreu mas nunca teve apoio] }
$$

66 Continuam a apoiar muitas actividades amadoras e de pouca relevancia artística, marionetas, fantoches, actividades de juntas de freguesia e não de uma instituição como a DGartes.

[192 - música, concorreu mas nunca teve apoio]

6

Deveriam empreender-se esforços para a implementação de mais programas com as características do Programa "Pegada Cultural".

[318- música, nunca concorreu]

6 Valorização de uma vertente de ligação entre actividade artística e património histórico-cultural.

$$
\text { [236 - música, teve apoio] }
$$

6f É urgente criar apoio para artistas emergentes, para novas estruturas. É verdade que há responsabilidade em manter as estruturas já existentes, com trajecto e história, mas não podemos fazer com que estas estruturas serviram de tampam ao surgimento de outras. Não sendo responsabilidade das referidas estruturas, cabe à DGArtes, criar apoios especificamente para estas estruturas. Normalmente os pontuais servem ou serviam para cobrir esta carência, mas a verdade é que com os cortes, os pontuais passaram a "servir", maioritariamente, para apoiar estruturas que deixaram de ter apoio.

[46 - teatro, concorreu mas nunca teve apoio]

66 apoio extra às Estruturas que absorvam temporariamente jovens artistas recém saídos das Escolas de Artes. Um criador após três anos de estudos superiores ou profissionais deve continuar a desenvolver as suas ferramentas junto de artistas e profissionais com experiência, antes de criar as suas próprias Estruturas

[90 - teatro, teve apoio] 
66 Sugerimos a criação de duas novas linhas de apoio. Uma para as entidades que têm espaços próprios de apresentação para que os custos de funcionamento dos espaços não desviem as verbas que se destinam à criação. Outra linha seria para a aquisição de equipamentos de luz, som e vídeo para que os equipamentos culturais se possam modernizar, uma vez que a tecnologia tem um papel fundamental na apresentação de espectáculos e evolui muito rapidamente.

[360 - teatro, teve apoio]

\section{Novas entidades e estruturas estabelecidas}

66 Consideramos que na avaliação dos projetos submetidos a concurso deveria ser considerado o cumprimento dos projetos anteriores em que a estrutura esteve envolvida, quer nos aspetos de intervenção artísticos e sociocultural, quer nos aspetos financeiros e administrativos.

[363 - dança, teve apoio]

6 As Companhias com um historial de pelo menos vinte e cinco anos de actividade permanente e com mérito, deveriam ser convidadas para a formalização de contratos-programa e não concursos, como acontece em outras áreas do desenvolvimento do país, que no que concerne aos projectos instalados nas regiões, deveriam passar por decisão maioritária do fluxo organizativo do "desenho" da administração regional em vigor (CCR's, CIM's, Autarquias, Universidades e Politécnicos, Agrupamentos Escolares, IPS's, e outros organismos/comunidades relevantes no desenvolvimento regional).

[267 - teatro, teve apoio]

\section{Estudos e avaliação}

É referida a necessidade de estudos de caracterização do terceiro sector ligado às artes (e não apenas os artistas), estudos de caracterização das procuras culturais, efetivas e potenciais, por região.

6 É necessário que a DGArtes realize um estudo e saber que público tem demasiada oferta e que público especifico é subvalorizado, de modo a colmatar carências a nível artístico - Seja numa região ou público especifico. É importante a DGArtes procurar saber quais os projetos artísticos que ocorrem onde a arte não chega. É essencial a DGArtes saber quais os projetos que envolvem a comunidade - Seja através da formação, criação, pesquisa, etc. É elementar a 
DGArtes responder a seguinte questão: Será a Arte um luxo ou uma necessidade?

[509 - teatro, concorreu mas nunca teve apoio]

\section{Acompanhamento e avaliação dos contratos}

6 Deverá ser criada uma maneira de avaliação que consiga ser objectiva, imparcial e justa. Não poderá ser possível uma pessoa do Júri conseguir influenciar ou desconsiderar um projecto, apenas porque sim, sem ter de justificar porque dá a nota de 3 , não deu 4 ou 2 . Não pode ser subjectivo a este ponto, Mas o mais importante é mudarem os técnicos da Dgartes que estão a avaliar os projectos, é criminoso o que fazem.

[87 - música, teve apoio]

66 a DGArtes é constituída por técnicos, e estes devem-se restringir às suas capacidades. Não reconheço, no domínio das artes plásticas, a qualidade critica para emitir opinião sobre projectos artísticos, e penso que esta é uma opinião consensual. O que, em si, não tem qualquer problema. Uma coisa é ter um artista como Fernando Calhau à frente da DGA, outra é ter estes técnicos, puramente administrativos. A decisão de apoios deve passar para o meio artístico, sobretudo aquele que tem provado internacionalmente - e não apenas no context português, estar à altura de "competir". São estas pessoas, e estes artistas, que devem ser apoiados.

[131 - artes plásticas, nunca concorreu]

6

Do ponto de vista da entidade que represento, deveria haver um afastamento no que respeita aos preconceitos sobre o tipo de entidade que apresentam candidaturas. Nem sempre as empresas são reais empresas no sentido comercial, assim como associações sem fins lucrativos podem esconder ordenados reais. Facilmente uma empresa tem um dependente directo e milhares indirectos, e uma associação sem fins lucrativos apresenta alguns directos e nenhum indirecto. Com isto quero dizer que as denominações podem não significar que um projecto possa alcançar maior número de pessoas (in)dependentes ou público e que os projectos devem ser avaliados não pelo nome de quem se candidata mas por uma valorização da continuidade social/cultural. Volto a salientar a importância das comissões de acompanhamento, que têm de estar no terreno e escrutinar as acções das entidades apoiadas. Compreendo que isso implica um orçamento maior para a DGArtes a nível de recursos humanos mas, infelizmente em Portugal, só assim se garante um maior rigor na atribuição dos apoios.

[66- música, nunca concorreu] 
6 Monitorização e impactes: crucial desenvolver um esquema de monitorização de execução e avaliação de resultados e impactes, que permitisse tirar o foco da execução financeira, colocando-o sobre a qualidade dos projetos, tendo em conta os seus resultados e impactes nas comunidades onde se inserem. Um esquema exequível e flexível, que permita a adequação às diferentes realidades, que poderá ser desenhado em conjunto entre a entidade e técnico da DGArtes na sequência da atribuição do financiamento. Este sistema permitiria atribuir os financiamentos às estruturas que teriam como compromisso executar atividades e atingir determinadas metas. Algumas regras de flexibilização da gestão do financiamento: por exemplo desvio entre rúbricas e atividades, uma percentagem que não obrigasse a pedido de alteração

[154 - outra área, teve apoio]

66 Urge proceder à definição de estruturas profissionais / amadoras; Urge corrigir a indefinição entre Cultura / Educação; Urge criar um estrutura específica de apoio às estruturas. Julgamos que a DGartes poderia agilizar e fomentar o contacto entre congéneres europeias que pudessem acolher espectáculos e cofinancia-los disponibilizando "listas" de contactos ou "oportunidades" de financiamento que essas congéneres tivessem. Assim potenciar-se-ia o trabalho e investimento da Dgartes.

[348 - música, teve apoio]

\section{Políticas culturais para as artes}

6 Planeamento político do que se pretende para a Cultura, Ciência, Tecnologia, e em conformidade Educação e para esta a prioridade, é preciso pagar aos professores como na Coreia do Sul ou na Filândia, para que os melhores escolham a profissão e nunca a deixar para os piores como hoje acontece.

[50 - artes plásticas, nunca concorreu]

6 Todas as entidades de programação que concorrem à dgartes estão a substituir o papel que o estado central a nível local. Pensamos que será primordial mudar a forma como a comunicação do papel do estado para as artes deveria mudar. Os termos "subsídios", "apoios" deveriam ser exterminados do léxico como comunicam as políticas culturais aos media. $O$ estado central financia entidades locais em que delega nestas, as responsabilidades politico culturais que não pode executar do poder central. $O$ termo apoio ás artes é imensamente redutor e deverá ser mudado porque é um paradoxo. Não existe nenhum apoio mas existe um contracto estatal para as políticas culturais. Toda a terminologia é antiga e tem de ser actualizada de forma a que os media e o público em geral compreendam realmente a importância destas entidades no terreno.

[514 - cruzamentos disciplinares, teve apoio] 
6 Seria mais producente que a política cultural fosse pensada concertadamente e a longo prazo e que o modelo de apoios não mudasse sempre que muda o aparelho governativo. Isto é aplicável a todos os projetos de continuidade em todas as áreas, sejam elas sociais, económicas ou sociais. É impossível conseguir continuidade num projeto sem um mínimo de estabilidade.

[407 - música, teve apoio]

6 Lamentamos o desinvestimento no Apoio às Artes por parte dos Governos dos últimos anos. Lamentamos que os cortes de 61\% efectuados em 2011 e 2012 para o orçamento do Apoios às Artes não tenham ainda sido repostos, ao contrário do que as verbas inscritas no OE para a Cultura podem levar a crer. Alertamos para que o Estado deva ter em consideração a recomendação da UNESCO em que o apoio à Cultura deve tender a médio prazo para o valor de $1 \%$ do PIB. Defendemos, no entanto, que o Apoio às Artes não deve ser confinado unicamente a uma questão financeira, mas sim ter em conta uma estratégia política a longo prazo para o sector.

[417 - teatro, teve apoio]

66 Mas ou menos tudo foi abordado, Pensamos que as entidades organizadoras de espectáculos (teatros, auditorios, museos, festivais) e os artistas ou grupos tem de ser em candidaturas separadas. Pensamos que se debe pedir um compromiso na criação contemporânea às entidades programadoras para tornar normal a programação nesta área, juntando esforços e imaginação nas formas e nos modos como se pode concretizar isto. Há que cuidar a criação atual, mas é preciso um compromiso de qualidade e também é preciso que os projetos e peças que são criados tenham uma vida e existencia mais longa já que a maioria dos grupos na vertente de criação contemporánea se dedicam a estrear peças, mas não se preocupam de as voltar a tocar, de as melhorar, de dar a oportunidade ao criador/compositor de as corregir e as melhorar, de as gravar, de as editar, ,., temos de olhar o todo de uma forma mais orgánica... penso que de pouco serve dedicarse so a um aspecto, quando não se considera o total. Neste campo é fundamental e a DGArtes deveria contemplar isto.

[405 - música, teve apoio]

\section{Apoiar artistas}

66 Nos últimos tem-se assistido a uma situação extremamente injusta: paga-se ao produtor, ao designer, ao segurança, à senhora da limpeza... mas não ao artista!! Quando a razão de ser de todo o evento é a mostra do seu trabalho. Isto é perverso e insustentável.

[83 - cruzamentos disciplinares, teve apoio] 
6 Apoio à integração de artistas no contexto económico e na estrutura neo-liberalista em que vivem deveria ser uma responsabilidade pública encarada com seriedade. Claro está que para isso é necessário investir tempo, dinheiro e contratar responsáveis comprometidos. Neste momento acho que este é o problema de raiz. Para que tudo o resto possa ser questionado.

[8- cruzamentos disciplinares, nunca concorreu]

66 De uma maneira geral, creio que o grande problema das artes é a falta de dinheiro para pagar aos recursos humanos. E nesse sentido, seja atividade ou estrutura deveria valorizar sempre o profissional. A DGArtes deveria ser uma entidade que se preocupava com a dignidade do artista e isso passa em primeiro lugar pela sua remuneração. A ideia de que artista ganha pouco dinheiro é a morte do artista. Do ponto de vista das instituições, assusta-me verificar como algumas dependem tanto do apoio da DGArtes. Não tendo apoio da DGArtes, não têm sustentabilidade. Isso não é saudável e a DGArtes podia procurar repensar isto. Se as instituições não sabem procurar mecenas, desenvolver trabalhos que fidelizem cada vez mais públicos e que cheguem a novos públicos, então irão fechar as portas quando não receberem financiamento. Não respondo diretamente à vossa pergunta, porque acho que é preciso ver esta questão de mais prismas.

[92 - cruzamentos disciplinares, concorreu mas nunca teve apoio ]

64

Seria importante a DGArtes também prover a atribuição de apoios financeiros para aperfeiçoamento contínuo de artistas, técnicos e gestores; através de cursos ou workshops no país e fora.

[162 - cruzamentos disciplinares, concorreu mas nunca teve apoio]

66

Volto a apresentar a ideia da existência de um rendimento básico dado a artistas de forma a evitar a armadilha da pobreza e a precariedade dos mesmos.

[121 - música, nunca concorreu]

6 Contemplar solos e solistas como forma de integração num mercado que prima pela sobrevalorização do coletivo talvez fosse um elemento a ter em conta à semelhança do que se faz em outros países onde um indivíduo também é reconhecido como embaixador de outro país.

[176 - teatro, concorreu mas nunca teve apoio]

66 A crescente e perniciosa candidatura de centros de investigação e fundações aos apoios à cultura. Estas entidades concorrem com criadores individuais e 
entidades pequenas, com pouca experiência de gestão e sem estruturas de apoio.

[508 - artes digitais, teve apoio]

\section{Outras fontes de financiamento}

Este é também um aspeto referido por diversas entidades em questões antes colocadas, que merece nesta última parte algumas novas referências, designadamente na relação com o turismo, por um lado, e o mecenato, por outro.

6 Reitera-se o indispensável envolvimento do sector do turismo no apoio às actividades internacionais, libertando, assim, meios financeiros da cultura para acorrer aos escalões nacional e local de forma mais confortável.

[275 - música, teve apoio]

6 A necessidade de uma Lei do Mecenato que incentive de facto o investimento das grandes empresas em projetos fora da órbita pública.

[271- música, teve apoio]

\section{Descentralização}

A descentralização, a correção de assimetrias e a circulação no apoio às artes são outros aspetos referidos nos contributos desta última questão.

6 Pela nossa experiência própria e pelo contacto com outras companhias, um pouco por todo o país, constatámos que existem especificidades inerentes às estruturas sediadas fora dos grandes centros urbanos: - necessidade de polivalência dos membros das equipas, que desempenham sempre várias tarefas ou funções; - necessidade de manutenção das equipas, devido à sua polivalência e também pela escassez de profissionais que queiram trabalhar e viver numa localidade pequena; - dificuldades de acesso a materiais e equipamentos diversos; - necessidade de desenvolvimento de atividades dirigidas a diversos públicos-alvo; - constante difusão e itinerância de espetáculos; - manutenção de espetáculos em cena por períodos longos, por vezes mais de 2 anos, devido à sua itinerância intermitente, entre outros aspetos. Como tal, acreditamos que, as estruturas que desenvolvem a sua atividade fora de grandes centros populacionais, garantindo igualdade territorial no acesso das populações a fenómenos artísticos, cumprindo assim a Constituição Portuguesa, devem ser va- 
lorizadas no modelo de apoio às artes, através da criação desse item de avaliação ou através de majoração da pontuação na avaliação das suas candidaturas.

$$
\text { [503 - teatro, teve apoio] }
$$

66

A descriminação entre Litoral e Interior, já referida, não potencia a vontade de descentralizar. No caso da região Centro não é a mesma coisa de falar de distritos como Coimbra ou Aveiro, em contraponto com Guarda ou Castelo Branco. Essa descriminação é notória quando falamos da captação de apoios financeiros ou mesmo de aspectos de comunicação ou informação (como exemplo, a realização de reuniões de esclarecimento invariavelmente em Coimbra que nos obriga a deslocações caras e morosas).

[426 - teatro, teve apoio]

66 É urgente alimentar e acarinhar o trabalho que é feito fora dos grandes centros urbanos. O país tem gente muito resistente, muito resiliente, mas com um limite. Trabalhar fora de um grande centro acarreta muitas mudanças de vida, muitas adaptações, reduz ou anula a hipótese de conjugar diferentes trabalhos com diferentes estruturas, é necessário dar estabilidade e condições de trabaIho Às estruturas. O governo deve combater a desertificação do país apoiando o que existe e motivando a criação de outros colectivos e agentes culturais, não esmifrando os que se matam a trabalhar. A dada altura, o agente cultural questiona-se: "ando aqui feito parvo a fazer o quê?"quando não há estabilidade financeira, as dificuldades em conseguir apoios são enormes, não há grandes empresas, não há apoio decente da administração local, enfim. As forças estão no limite, mostrem que o país não é Lisboa e Porto, dêem um empurrãozinho ao interior do pais e provem-nos que afinal vale a pena ser resiliente.

[437 - teatro, teve apoio]

(6)

Uma das nossas grandes expectativas é que o novo Modelo de Apoios venha a corrigir significativamente o enorme desequilíbrio existente na atribuição dos apoios entre os territórios de maior e menor índices de desenvolvimento. " correcção das assimetrias regionais" é um dos preceitos que tem acompanhado os Modelos de Apoios e as políticas da respectiva tutela da Administração Central. O reconhecimento da existência de assimetrias no nosso território é transversal a todos sectores e população em geral. Neste caso dos apoios às artes, faltam medidas concretas e mais ambiciosas que contribuam significativamente para a alteração desta realidade. Neste sentido, deixamos aqui algumas sugestões e considerações: 1 . Majorar de forma significativa as "zonas de menor índice de desenvolvimento", associando este Factor aos critérios e parâmetros de apreciação e avaliação das despesas e receitas, como medida compensatória da capacidade de gerar receitas próprias e angariar outras fontes de financiamento; 2 . Definir uma formula equilibrada de distribuição dos 
apoios pelas regiões e sub-regiões de todo o território, tendo como referências o índice de desenvolvimento, a dimensão populacional e a oferta cultural. No caso da oferta cultural, tendo em conta o número de equipamentos e instituições culturais de carácter profissional existentes (Entidades de Criação e Produção, Teatros, Museus, Fundações, Salas de Cinema, Empresas de Conteúdos, entre outras); 3 . A situação e enquadramento da actual Zona Norte é particular quando comparada com as restantes Zonas do território nacional. Por um lado, pelo elevado número de municípios que engloba. Por outro, pelo grande desequilíbrio que apresenta entre os distritos que a compõe quando analisados os índices de desenvolvimento e a densidade populacional - a grande área metropolitana do Porto, com um dos índices de desenvolvimento e densidade populacional mais elevados do País, e a área de Trás-os-Montes e Alto Douro, numa situação completamente oposta. Neste sentido, à semelhança da Zona de Lisboa e Vale do Tejo, parece-nos de toda a justiça, avaliar a possibilidade de atribuição dos apoios distintivamente à Àrea Metropolitana do Porto e à Área de Trás-os-Montes e Alto Douro.

[494 - teatro, teve apoio]

6f Nos apoios às artes fala-se e tem-se discutido numa verdadeira forma de abranger todo o território nacional, portanto tem-se reforçado a ideia da circulação. Ora circulação não é descentralização. Ou seja, uma verdadeira descentralização implica que os projectos, as companhias que a queiram fazer na realidade tenham os meios necessários (e não só com o poder local) para se poderem fixar, trabalhar, desenvolver em determinado território e isso só é possível com um verdadeiro investimento ou um mais abrangente investimento tanto a nível de critérios de concurso como de aumento de apoio monetário para as regiões que têm sido menos favorecidas.

[37 - teatro, teve apoio]

\section{Plataforma de encontro de entidades e profissionais}

Outras propostas estão ainda presentes. Destaca-se uma última, direcionada para a criação de uma plataforma específica.

6 O apoio às artes poderia estar associado à criação de uma plataforma digital de encontro de criadores, estruturas de criação e programação e todos os profissionais afectos às artes (e.g. técnicos de luz ou som, figurinistas, director de actores, ...). Esta plataforma poderia dar resposta de networking entre os diferentes "actores", promover a interdisciplinariedade, a co-produção, a contratação e até circulação de espectáculos e profissionais entre estruturas. De certa forma poderia ser revestida de uma medida de combate à tal referida e mediática precariedade. Resumidamente: uma maior proximidade, num sentido lato, é o que vai diferenciar os novos modelos de apoio às artes.

[452 - teatro, nunca concorreu] 


\section{CONCLUSÕES}

O presente estudo foi realizado num contexto marcado pela existência de um Modelo de Apoio às Artes (MAA) cujo enquadramento legal data de 2006, pela diminuição do seu financiamento entre 2011 e 2016 - situado num patamar significativamente mais baixo do que até 2010 - e pelo objetivo político por parte do XXI Governo Constitucional de proceder à sua revisão de um modo participado, incluindo a auscultação da generalidade das entidades nele interessadas. Assim, o universo de trabalho é constituído pelas entidades profissionais do terceiro sector das artes inscritas na plataforma eletrónica da DGArtes na qual é feita a gestão dos processos - o universo de trabalho do estudo.

$O$ estudo visava assim auscultar o sector em moldes que foram referidos na introdução e na metodologia e cujos procedimentos e resultados em termos de participação e das características dos participantes foram detalhados nos capítulos seguintes. Deste estudo resultou um número considerável de contributos cujos posicionamentos foram analisados e ilustrados com as citações diretas no capítulo anterior.

Sintetizam-se agora as principais conclusões do estudo e referem-se depois as sugestões de entidades que se afiguram mais adequadas em função do objetivo central - informar, a partir dos posicionamentos expressos no inquérito, a revisão em curso do MAA.

De um modo geral, é possível fazer um balanço muito positivo da metodologia de inquérito adotada no estudo. Tratou-se de um processo de recolha de contributos muito participado e valorizado pelo sector, a que não é alheia a realização de cinco reuniões desconcentradas, com o secretário de Estado da Cultura e a diretora-geral das Artes, de apresentação do estudo. O universo de trabalho é constituído por 2.787 registos e corresponde ao conjunto de entidades que tiveram a oportunidade de participar. A amostra de entidades que constitui a base primária é muito significativa, pela quantidade e pela diversidade medida pelos parâmetros de caracterização solicitados também no estudo. Da participação das 522 entidades com questionários válidos resultou um conjunto muito importante de contributos nas questões abertas do estudo (a que correspondem cerca de 16.000 unidades de análise), que suscitaram um trabalho intenso de análise de acordo com a grelha definida com vista à identificação de posicionamentos suscetíveis de contribuir para o desenho de um novo modelo de 
apoio nas várias dimensões que o compõem, o orientam e o informam. Nos posicionamentos, o MAA foi abordado e questionado em todas as suas dimensões, numas tendencialmente de sentido mais positivo, noutras mais criticamente negativo, normalmente de uma forma polarizada, mas sem deixarem de se identificar, entre os extremos, diversos matizes. Mas foram, de modo igualmente muito participado, avançados contributos muito relevantes e propostas que podem contribuir para a revisão do modelo.

A síntese que a seguir se faz decorre das principais tendências identificadas nos posicionamentos. De acordo com a vertente qualitativa dominante do estudo, são referidas tendo sempre em conta a sua diversidade e não apenas (mesmo quando tal é possível) quantificações e sobretudo quantificações maioritárias.

Importa também recordar que os posicionamentos se situam por referência ao quadro do MAA (o que significa regulamentos, disposições gerais, processos de candidatura, processos associados aos contratos quando beneficiários) e decorrentes dos contributos expressos que refletem a experiência das entidades de relação com o modelo (como beneficiárias mas também com uma experiência parcial - por exemplo terem sido apenas candidatas - ou apenas de experiência exterior, nunca tendo concorrido, eventualmente reduzida à leitura dos regulamentos e ao contacto com a plataforma eletrónica) e da entidade (coletiva ou singular), em todo o caso não apenas a visão particular de quem responde (entidades coletivas) ou de artista ou criador enquanto tal (entidades singulares).

Ao longo do capítulo anterior foram referidos com detalhe os temas que se destacaram na análise dos contributos das entidades participantes sobre o MAA para as várias questões e foram identificados, e ilustrados, os diversos posicionamentos.

Faz-se aqui uma síntese final das principais conclusões do ponto de vista da revisão do MAA. Note-se, contudo, que na leitura destas conclusões deve ser tida em conta a grande diversidade de perspetivas, quanto aos fundamentos e ao sentido atribuído aos argumentos aduzidos, aliás patentes nas citações que os ilustram. Em termos expositivos, segue-se a ordem das questões tal como constam do questionário (ver anexo 2).

\section{Modalidades de concurso por tipologia de atividade (criação/programação)}

- Separar os concursos por tipo/domínio de atividade é a tendência maioritária nos posicionamentos. 
- Contudo, tanto os que defendem este ponto de vista como os que defendem que se devem manter juntos avançam frequentemente condições que os relativizam.

\section{Áreas artísticas objeto de apoio}

- Manter as atuais áreas é o posicionamento mais frequente.

- Questionadas são as áreas cinema e literatura (porque cobertas por outros organismos do MC).

- Sugere-se distinguir as áreas de artes do espetáculo de outras, sobretudo arquitetura e design.

- Alargar, nas áreas das artes do espetáculo, ao circo e às artes de rua.

\section{Despesas a considerar nos apoios}

- O posicionamento mais frequente é considerar as despesas com atividades e estrutura de forma equilibrada.

- As despesas com atividades (maioritária ou equilibradamente face às despesas de estrutura) recolhem a parte mais substancial dos posicionamentos e sustentam que essa é a parcela em que devem incidir os apoios.

- Os posicionamentos que privilegiam a estrutura sustentam que essa é uma forma de fortalecer as organizações e combater a precariedade de forma mais eficaz.

- Vários posicionamentos relativizam a sua opção, considerando que o balanço entre os dois tipos de despesa deve depender do apoio em causa (da modalidade, do domínio, do projeto...).

\section{Mecanismos de atribuição dos apoios}

- A grande maioria dos posicionamentos é favorável a um modelo de atribuição de apoios por concurso público.

- É igualmente considerada a adoção de mecanismos que contemplem de forma ponderada a possibilidade de outros apoios não concursais (financeiros e não financeiros).

- É igualmente apontada a revisão dos apoios atualmente existentes. 


\section{Relações entre a entidade e a DGArtes}

- Uma parte significativa das entidades menciona não ter qualquer relação com a DGArtes.

- Os posicionamentos das entidades com experiência de relação com a DGArtes tendem a polarizar-se entre uma relação caracterizada positivamente e que, em vários casos, evidencia a insuficiência de meios da DGArtes (em particular humanos), e uma outra, de sentido negativo, que caracteriza a relação como excessivamente burocrática, distante para com as entidades (uma vez que é remetida para a plataforma eletrónica), com pouco apoio técnico e jurídico, reduzida às questões concursais e oscilante ao longo do tempo em função da direção e das orientações da tutela.

\section{Processo administrativo e plataforma eletrónica}

- Evidencia-se uma defesa bastante alargada da plataforma eletrónica como instrumento através da qual é feita na DGArtes a gestão dos processos administrativos dos apoios.

- É igualmente evidente a necessidade de a melhorar, de simplificar processos e de os adequar às características das entidades candidatas e beneficiárias.

- Sugere-se a introdução de novas funcionalidades, mas chama-se também a atenção para o cuidado que deverá ser posto na eventualidade de serem feitas alterações de modo a não colidir com o esforço de adaptação já feito por muitas entidades.

- Chama-se a atenção para a necessidade de apoio à instrução das candidaturas.

- Considera-se que os processos de candidatura devem valorizar a componente artística dos projetos.

\section{Comissões de apreciação}

- Os posicionamentos são tendencialmente favoráveis à existência de comissões de apreciação, mas apontam diversos problemas, desde logo a composição e as competências dos seus membros. 
- Parte dos posicionamentos defendem que as comissões devem incluir especialistas e também técnicos da DGArtes.

\section{Comissões de acompanhamento e avaliação}

- É bastante alargada a valorização do acompanhamento e da avaliação na execução dos contratos.

- É bastante alargado o tom de crítica ao modo de funcionamento (ou não funcionamento, de todo) das comissões.

- Há posicionamentos que, embora não destoem quanto à importância do acompanhamento, sobretudo para fazer face às dificuldades que se colocam no terreno na concretização dos projetos, questionam a necessidade das comissões, dando como exemplos outros programas de apoio exteriores à DGArtes em que são solicitados relatórios, sem recurso a comissões.

\section{Relações entre a entidade e as DRC}

- A maioria das entidades menciona não ter qualquer relação com as DRC.

- No conjunto restrito das entidades que têm alguma relação com as DRC, salienta-se uma relação caracterizada positivamente e que, em alguns casos, procura evidenciar a falta de meios (financeiros e humanos) das DRC.

- Os aspetos negativos que recolhem mais contributos prendem-se com a fraca proximidade, conhecimento do projeto artístico e presença nas iniciativas da entidade.

- Independentemente de posicionamentos mais ou menos críticos, uma parte significativa das entidades reconhece o papel relevante das DRC na relação com as entidades artísticas e com os territórios e defendem maior autonomia e poder de decisão, maior delimitação de competências face à DGArtes e a redefinição de uma estratégia de intervenção para os territórios

- Em geral, propõe-se um papel mais ativo das DRC na promoção das entidades e dos seus projetos. 


\section{Articulação entre administração central e local no quadro do apoio às artes}

- Quase metade das entidades dizem não ter relação com autarquias locais; um terço refere uma relação de apoio ou mesmo parceria formal; as restantes entidades referem algum tipo de ligação sem a caracterizar, sendo que uma parte residual refere explicitamente as autarquias como compradoras.

- Constata-se uma enorme dispersão de temas referidos e pontos de valorização ou crítica do trabalho autárquico.

- Perceção contrastante do processo político local: por um lado, valorização da proximidade e conhecimento do terreno pela administração autárquica; por outro, desconfiança face a riscos de falta de transparência e partidarização.

- Défice de competências técnicas específicas no domínio das artes, por vezes associado à insuficiente delegação de competências e recursos por parte da administração central.

- Definição de atribuições e esferas de atuação entre o poder central e local, seja no sentido de articulação mais próximo, seja pelo contrário no sentido de demarcação de funções. Para além dos posicionamentos mais polarizados, a reflexão das entidades sobre este tema traduz-se num extenso leque de hipóteses e fatores críticos da articulação política a nível central e local.

- Quanto à modalidade de apoio "acordos tripartidos", as entidades com conhecimento e opinião são uma minoria dentro da amostra inquirida e o posicionamento sobre a manutenção desta modalidade de apoio é bastante crítico. Entre as condições apontadas para uma necessária melhoria estão: viabilizar mais do que um protocolo por autarquia; introduzir mecanismos de monitorização e avaliação dos protocolos estabelecidos; obrigatoriedade de comparticipação financeira autárquica (e não apenas de apoio em espécie).

\section{Redes de programação e articulação com o MAA}

- As respostas referem-se a diferentes aceções da expressão, como sejam: plataformas formais ou informais de circulação de produções artísticas; protocolos de programação entre agentes e entidades; redes de equipamentos e infraestruturas. 
- As redes de programação são vistas, de forma geral, como elemento fundamental da política pública para o sector. Talvez por isso, o leque de posicionamentos é muito disperso, desde a total integração entre modelo de apoios e redes de programação (por exemplo, impondo uma quota de produções apoiadas na programação dos equipamentos integrantes de redes públicas ou com apoio público) até à total separação da gestão dos dois instrumentos de política pública (cabendo exclusivamente à DGArtes a gestão do sistema de apoios).

- Necessidade de maior financiamento e distinto do modelo de apoio.

- Referências favoráveis a programas de circulação promovidos pela DGArtes (exemplo: Programa Território Artes).

- Defesa de mecanismos que assegurem transparência e diversidade de produções programadas.

\section{Internacionalização - projetos a contemplar, posição da DGArtes nos projetos internacionais em rede}

- O apoio à internacionalização deve ser dirigido preferencialmente à circulação de projetos. Contudo, esta e as demais opções consideradas (formação, residências, plataformas e convites a programadores/curadores) - embora reúnam menor apoio por parte das entidades - são vistas com frequência como complementares entre si.

- Relevância do objetivo da internacionalização, frequentemente considerado prioritário, em várias vertentes: para cruzar experiências e enriquecer os projetos; para promover relações de trabalho e alargar mercados para a circulação dos projetos; para promover a arte, a cultura e os artistas nacionais.

- Sem descurar a importância das relações internacionais entre pares, colocam-se ainda assim reservas com chamada de atenção para que nem todas as entidades têm de ter esta vertente entre os seus objetivos e prioridades.

- Reforço do papel de intermediação da DGArtes nas atividades de internacionalização das entidades: de incentivo, como facilitadora, de representação institucional internacional nos programas internacionais, designadamente europeus, de procurar garantir condições de digressão internacional, de presença em redes internacionais. 
- Defende-se a criação de gabinetes interministeriais, um papel mais interventivo da DGArtes em articulação com outros ministérios e organismos implicados nas relações internacionais no âmbito de uma política cultural de internacionalização.

- Quanto ao papel da DGArtes nos projetos internacionais em rede, defende-se, por um lado, o seu reforço como interlocutor/mediador e, por outro, como disseminador de informação relevante para agentes nacionais e estrangeiros.

\section{Públicos, valorização, como considerar esta vertente no MAA}

- A vertente dos públicos deve ser considerada como critério de avaliação, é a forma mais referida, seguida de fator de majoração e como modalidade de apoio. No entanto, vários posicionamentos assinalam duas ou mais opções, com destaque para critério e modalidade de apoio.

- É visível alguma fratura entre os posicionamentos que defendem a valorização dos públicos (na sua diversidade, mas também na sua especificidade em função do projeto, da modalidade, da localização geográfica das atividades), da receção (e da mediação), por um lado, e a valorização da criação, por outro.

- A relação com a modalidade de apoio é frequentemente referida: a relação com a programação é destacada positivamente, com a criação é desvalorizada.

- A possibilidade de a quantidade de espetadores poder ser um critério com influência na atribuição dos apoios é bastante mencionada para, com raras exceções, ser fortemente contestada.

- Destaca-se a relevância do trabalho de formação de públicos e adianta-se, articuladamente ou não, aspetos de desenvolvimento de públicos.

- Chama-se a atenção para que a valorização dos públicos está contemplada no atual modelo (o que não significa necessariamente adesão ao modo como está contemplada), refere-se especialmente a articulação entre cultura e educação e o trabalho com as comunidades, chama-se a atenção para questões territoriais e de exclusão social. 


\section{Questões laborais, precariedade}

- De modo geral, os posicionamentos identificam a precariedade como uma questão complexa e mais abrangente, que ultrapassa em muitos aspetos o âmbito do modelo de apoio às artes.

- A maioria dos posicionamentos vai no sentido de contribuir com propostas para dar resposta à precariedade no sector.

- Uma parte significativa das entidades defende uma maior regulação da questão laboral por parte do Estado. Em articulação com esta ideia propõe-se igualmente que o Ministério da Cultura e a DGArtes assumam um papel mais interventivo a este respeito.

Soluções de apoio com diferentes sectores interministeriais, outros critérios de apreciação que não artísticos

- A articulação entre os apoios da tutela da cultura e apoios de outros ministérios é em geral valorizada, em especial se (ou na condição de) corresponder ao aumento do financiamento disponível. Por outro lado, embora menos frequente, é muito expressivo um posicionamento crítico dessa articulação e de defesa da autonomia do sector cultural.

- Essa oposição é mais clara quando estão em causa critérios de apreciação não estritamente artísticos. A possível ligação a outros sectores é valorizada, por exemplo, na articulação com a comunidade local ou na educação (embora neste caso haja a remissão para a necessidade de as políticas educativas terem um maior espaço para a produção artística); os posicionamentos são bastante mais divididos quanto se trata de considerar os efeitos económicos da atividade cultural (em particular, quando se considera a eventual ligação com o turismo).

- Verifica-se uma leitura negativa das implicações processuais, como a falta de clareza das estratégias políticas implicadas e o aumento da burocracia.

\section{Aspetos positivos e negativos no regulamento de apoio às artes}

- Os posicionamentos apresentam grande dispersão e oscilam entre o suporte incondicional e a recusa total ao MAA. 
- Os argumentos negativos são substancialmente mais numerosos que os positivos, mas os posicionamentos positivos são mais genéricos e abrangentes, os negativos de carácter mais específico ou pormenorizado.

- De sentido positivo: são referidos a própria existência dos apoios, a sua abrangência artística, territorial, de entidades, de domínios de atividade, a sua regularidade, o processo participativo e a realização do EPEA.

- De sentido negativo: são mencionados a escassez de financiamento no Orçamento do Estado para a cultura e para o MAA, bem como limitações específicas que se manifestam, apesar de tudo, face aos aspetos mais gerais mencionados como positivos (e.g., centralismos de Lisboa e Porto, burocracia de procedimentos, irregularidade dos concursos, falta de comunicação da DGArtes, a realização do EPEA não esgota as necessidades de participação).

\section{Outros aspetos antes não abordados}

- Parte significativa dos posicionamentos reforça argumentos já antes aduzidos, no estudo ou fora dele, e não acrescenta "outros" aspetos antes não mencionados, mas são também feitas considerações em que tal acontece.

- Considera-se que a construção de um "novo modelo" passa não por um modelo único, mas por vários modelos, ou seja, por domínio de atividade artística (criação, difusão, programação).

- Chama-se a atenção para o apoio aos criadores emergentes.

- Refere-se a necessidade de uma linha específica de apoio para os teatros e cineteatros municipais (programas de redes).

- Sugere-se a introdução de soluções para entidades mais antigas, que não por concurso.

- Refere-se a importância de produção de conhecimento sobre diversas dimensões das artes, de estudos e de avaliação.

- Propõe-se também a criação de uma plataforma de divulgação para todos os agentes culturais ligados às artes. 


\section{Sugestões das entidades artísticas}

Na sequência da análise realizada e das conclusões antes apresentadas, sintetizam-se agora as sugestões de entidades. Embora partindo sempre dos posicionamentos das entidades face às várias questões que lhes foram colocadas no inquérito, a lógica da apresentação altera-se e segue agora as dimensões do modelo de análise do estudo de modo a aproximar as sugestões da arquitetura do regime de atribuição de apoios nas suas vertentes, as quais terão de ser vistas necessariamente de um modo integrado.

\section{Políticas de apoio às artes}

- Clarificação de objetivos a alcançar e melhoria da sua comunicação ao sector: embora os objetivos gerais das políticas estejam enunciados em vários instrumentos e sejam largamente consensuais, os objetivos a alcançar com os apoios que os concretizam em cada ciclo não parecem ser claramente definidos, delimitados e comunicados.

- Melhor articulação entre os vários níveis estatais (central, desconcentrado e local) envolvidos nos apoios às artes.

- Maior articulação do sector da cultura com outros sectores, suscetíveis de aumentar as atividades e o financiamento, procurando-se que a cultura seja o centro dessa articulação.

\section{Quadro normativo}

- Comunicação atempada dos objetivos visados com cada medida, dos calendários e das condições de participação, com antecipação e maior adequação aos ritmos de trabalho das entidades das diversas áreas.

- Flexibilização e adequação às características específicas da diversidade dos apoios, entidades, tipologia de programas, modalidades de áreas artísticas, domínios de atividade envolvidos, região.

- Aceitabilidade de despesas com estrutura e que visem combater a precariedade.

- Maior atenção aos artistas individuais.

- Inclusão de candidatos das regiões autónomas.

- Inclusão do circo e artes de rua entre as áreas artísticas elegíveis.

- Alargar o número de acordos tripartidos por autarquia. 


\section{Coordenação e execução dos processos (DGArtes)}

- Promover uma comunicação mais adequada da DGArtes com o sector tendo em conta os diferentes perfis dos seus destinatários e os diferentes modos de relação existentes.

- Maior atenção/proximidade com as entidades que desenvolvem o seu trabalho nas diversas regiões do país.

- Dotar a DGArtes de recursos de diversa ordem indispensáveis ao cumprimento da sua missão.

\section{Plataforma eletrónica}

- Simplificação, celeridade dos acessos eletrónicos.

- Simplificação crescente nas exigências de dados e informação redundante.

- Adequação aos diferentes perfis e necessidades dos utilizadores.

- Criação de área/plataforma de comunicação das atividades e dos agentes do sector.

\section{Disposições gerais}

- Simplificação, e clarificação, dos termos utilizados nos quadros normativos, designadamente cruzamentos disciplinares, e dos destinatários.

- Adequação aos objetivos visados e aos destinatários elegíveis.

- Calendários alargados, previsíveis e cumpridos.

\section{Submissão de candidatura}

- Simplificação dos procedimentos, na medida do possível, tendo em conta o enquadramento geral inerente aos procedimentos concursais públicos.

- Melhoria dos processos mediados pela plataforma eletrónica, designadamente quanto ao arquivo documental acumulado por candidaturas recorrentes.

- Melhoria da comunicação direta com os candidatos e realização de formação com vista a facilitar os processos de submissão de candidatura. 


\section{Apreciação de candidatura}

- Maior transparência dos processos de avaliação e seus resultados.

- Melhoria dos processos mediados pela plataforma eletrónica.

\section{Acompanhamento dos contratos}

- Maior transparência dos processos de acompanhamento e seus resultados, disponibilizando às entidades visadas os relatórios e demais documentação produzida.

- Criar condições para tornar o acompanhamento mais eficaz do ponto de vista do desenvolvimento dos projetos.

\section{Produção de conhecimento sobre os apoios às artes e sobre o sector}

- Proceder à avaliação científica regular dos apoios do ponto de vista dos objetivos definidos e dos seus resultados, em cada ciclo, com vista a acompanhar e a informar os ciclos seguintes.

- Dar continuidade aos processos participativos e de auscultação do sector, por forma a envolver os agentes das artes nos processos de formulação e de acompanhamento de medidas políticas mais adequadas aos objetivos e à realidade do sector.

- Mapear e caracterizar os equipamentos artísticos implantados no território, em particular os públicos, que resultaram de programas de investimento em parcerias das administrações central e local, de modo a dotar os responsáveis e o sector de informação atualizada sobre a realidade nacional.

- Desenvolver estudos com vista à caracterização dos agentes do sector, incluindo criadores, produtores e mediadores, nas vertentes profissional/amador, singular/coletivo, privado não lucrativo/lucrativo.

- Realizar inquérito sobre participação cultural da população para conhecer regularmente o contexto nacional das procuras, efetivas e potenciais, para as artes, os bloqueios à participação e os perfis sociais e de práticas. 
Feitas as sugestões específicas que se mostram adequadas a partir dos posicionamentos das entidades, deixam-se, a finalizar, três notas mais gerais.

A primeira vai no sentido do aprofundamento de linhas de análise e de procura de soluções específicas a partir dos contributos agora recolhidos, muito ricos e diversificados, e que não se esgotam no âmbito da exploração dos posicionamentos sobre o MAA aqui feitos e que seguiram necessariamente uma lógica analítica predominante por questão, e que sugerem novas abordagens transversais às várias questões ou, pelo contrário, mais específicas, o que, em qualquer dos casos, por constrangimentos vários e inerentes ao estudo, desde logo pelos objetivos e pelo calendário do projeto de investigação, estiveram fora do âmbito do presente estudo.

O segundo é a vantagem que eventualmente advirá da comparação dos procedimentos dos vários organismos do Ministério da Cultura que atribuem apoios, numa perspetiva integrada ainda que atenta à especificidade de cada área, no sentido de identificar possibilidades de simplificação dos processos e o grau de exigência de documentação das entidades candidatas - naturalmente dentro dos limites legais -, em geral processos muito consumidores de recursos e energias mas que poderá não só levar à sua simplificação mas também a ganhos de eficiência, quer na administração dos apoios, quer na atividade das entidades artísticas.

O terceiro refere-se aos programas de equipamentos de artes do espetáculo (e, por extensão, às áreas abrangidas pelo MAA), os quais se referem às infraestruturas que suportam a programação de conteúdos. Destaca-se aqui a importância da pesquisa sobre aquela área em particular, na sequência aliás do que foi feito com outros programas de redes de equipamentos, noutros domínios culturais, posto que correspondem a orientações emanadas da mesma tutela (Silva, 2004). Lançar o processo de produção de conhecimento com base nas diversas experiências portuguesas destes programas públicos, de que o processo de constituição da RPM - Rede Portuguesa de Museus é, entre os mais recentes (para não falar no da Rede Nacional de Bibliotecas Públicas, seminal deste ponto de vista) uma referência - desde logo pelo cuidado posto no processo interno de definição da suas linhas programáticas (Camacho, Monteiro e Freire-Pignatelli, 2001), bem como a articulação entre a implementação e o acompanhamento externo (Camacho, 2015) e o contexto em que ocorre (Neves, Santos e Lima, 2013) - parece ser outra linha de pesquisa fundamental no contexto das políticas públicas para a cultura em Portugal. 



\section{BIBLIOGRAFIA}

AAVV (2002), O Estado das Artes. As Artes e o Estado, Lisboa, Observatório das Actividades Culturais.

AAVV (2006), The Economy of Culture in Europe, Bruxelas, KEA, p. 355.

Bardin, Laurence (1977), Análise de Conteúdo, Lisboa, Edições 70.

Bina, Vladimir, Philippe Chantepie, Valérie Deroin, Guy Frank, Kutt Kommel, Josef Kotynek e Philippe Robin (2012), ESSnet-Culture Final Report, Luxemburgo, ESSnet Culture e Eurostat, p. 556.

Borges, Vera e Tiago Lima (2014), "Apoio público, reconhecimento e organizações culturais: o caso do teatro", Análise Social, 213 (XLIX, 4.ํ), pp. 926-952.

Borges, Vera e Tiago Lima (s/ data), Boletim Anual 2014, Lisboa, DGArtes e Dinâmia'CET/ISCTE-IUL, p. 27.

Bryman, Alan e James J. Teevan (2005), Social Research Methods. Canadian Edition, Oxford, Nova Iorque, Oxford University Press.

Camacho, Clara Frayão (coord.), Ana Sofia Gomes, Ângela Silveira, Fernanda Steiger Garção e Sandra Vaz Costa (2015), Plano Estratégico da Direcção-Geral do Património Cultural 2015-2019, Lisboa, DGPC.

Camacho, Clara Frayão, Joana Sousa Monteiro e Cláudia Freire-Pignatelli (2001), Rede Portuguesa de Museus: Linhas Programáticas, Lisboa, MC/IPM.

Camacho, Clara Frayão (2015), Redes de Museus e Credenciação: Uma Panorâmica Europeia, Casal de Cambra, Caleidoscópio.

DGArtes (2013a), Relatório da Recolha de Contributos aos Agentes Culturais. Inquérito Disponibilizado entre 20 de Agosto e 07 de Setembro de 2012, Lisboa, DGArtes, p. 66.

DGArtes (2013b), Resultado do Inquérito On-line aos Participantes dos Workshops Realizados pela Direção-Geral das Artes Avaliação da Utilidade dos Workshops, Lisboa, DGArtes, p.13.

Ferreira, Claudino, André Brito Correia, Paula Abreu, Sílvia Damásio e Marta Correia (2016), 5 Sentidos. Estudo sobre a Rede de Programação Cultural. Relatório, Coimbra, CES, p. 142.

Figueiredo, António Manuel e Elisa Pérez Babo (2015), "Territorialização das políticas públicas: inovação e cultura" em Viriato Soromenho- 
Marques, e Paulo Trigo Pereira, Afirmar o Futuro Políticas Públicas para Portugal Vol. II: Desenvolvimento Sustentável, Economia, Território e Ambiente, Lisboa, Fundação Calouste Gulbenkian, pp. 234263.

Foddy, William (1996[1993]), Como Perguntar: Teoria e Prática da Construção de Perguntas em Entrevistas e Questionários, Oeiras, Celta.

Garcia, José Luís (coord.), João Teixeira Lopes, José Soares Neves, Rui Telmo Gomes, Teresa Duarte Martinho e Vera Borges (2014), Mapear os Recursos, Levantamento da Legislação, Caracterização dos Atores, Comparação Internacional, Lisboa, SEC/GEPAC.

Garcia, José Luís, João Teixeira Lopes, Teresa Duarte Martinho, José Soares Neves, Rui Telmo Gomes e Vera Borges (2016), "Mapping the culture policies in Portugal. From incentive to crisis", International Journal of Cultural Policy, pp. 1-17.

Gomes, Rui Telmo, Vanda Lourenço e Teresa Duarte Martinho (2006), Entidades Culturais e Artísticas em Portugal, Lisboa, Observatório das Actividades Culturais.

Lacombe, Robert (2004), Le Spectacle Vivant en Europe: Modèles d'Organisation et Politiques de Soutien, Paris, La Documentation Française

Ministro da Cultura (2016), Orçamento do Estado / 2017 - 09 Programa Orçamental da Cultura, Lisboa, ministro da Cultura.

Neves, José Soares (2001), "Intervenção no Encontro", O Estado das Artes. As Artes e o Estado: Actas do Encontro Realizado em Lisboa, no CCB, a 19, 20 e 21 de Abril, Lisboa, Observatório das Actividades Culturais, pp. 8491.

Neves, José Soares (coord.), Joana Azevedo, Rui Telmo Gomes e Maria João Lima (2017a), Estudo Posicionamentos das Entidades Artísticas no Âmbito da Revisão do Modelo de Apoio às Artes: Metodologia e Resultados, workshop de investigação CIES-IUL, Lisboa, ISCTE-IUL (20 de setembro).

Neves, José Soares (coord.), Joana Azevedo, Rui Telmo Gomes e Maria João Lima (2017), Estudo Posicionamentos das Entidades Artísticas no Âmbito da Revisão do Modelo de Apoio às Artes: Principais Conclusões, sessões de apresentação promovidas pela DGArtes realizadas em Lisboa, T. N. D. Maria II e Faro, Teatro das Figuras (11 de julho); Coimbra, Convento de S. Francisco e Porto, Mosteiro de São Bento da Vitória (12 de julho); Évora, Fundação Eugénio de Almeida (13 de julho). 
Neves, José Soares (coord.), Jorge Alves dos Santos e Maria João Lima (2013), O Panorama Museológico em Portugal. Os Museus e a Rede Portuguesa de Museus na Primeira Década do Século XXI, Lisboa, DGPC/SEC.

Santos, Helena e Ricardo Moreira (2013), Estudo sobre os Apoios Financeiros Diretos Concedidos pela Direção Geral das Artes às Atividades Artísticas (Apoios Bienais 2011 e Quadrienais 2009). Relatório Final, Porto, UP/ESFEP, p. 99.

Santos, Maria de Lourdes Lima dos (coord.), Lina Antunes, Idalina Conde, António Firmino da Costa, Eduardo de Freitas, Rui Telmo Gomes, Carmen Gonçalves, Helena Seitas Gonçalves, João Teixeira Lopes, Vanda Lourenço, António Martinho, Teresa Duarte Martinho, José Soares Neves, João Sedas Nunes, Elsa Pegado, Isabel Pires, e Francisco Silva (1998), As Políticas Culturais em Portugal, Lisboa, Observatório das Actividades Culturais.

Santos, Maria de Lourdes Lima dos (coord.), Rui Telmo Gomes, José Soares Neves, Maria João Lima, Vanda Lourenço, Teresa Duarte Martinho e Jorge Alves dos Santos (2004), Políticas Culturais e Descentralização: Impactos do Programa Difusão das Artes do Espectáculo, Lisboa, Observatório das Actividades Culturais.

Santos, Maria de Lourdes Lima dos (coord.), José Soares Neves e Jorge Alves dos Santos (2007), Estatísticas Culturais do Ministério da Cultura (EC-MC). Documento de Trabalho, Lisboa, Observatório das Actividades Culturais, p. 87.

Santos, Maria de Lourdes Lima dos (coord.), José Soares Neves, Jorge Alves dos Santos, A. Ribeiro da Silva e José A. Cristino Joana (2002), Base de Dados Estatísticos do Sector Cultural do Ministério da Cultura (Bdstat-MC), Volume I, Relatório Final, Lisboa, Observatório das Actividades Culturais/SG-MC, p. 132.

Silva, Augusto Santos (2004), "As redes culturais: balanço e perspectivas da experiência portuguesa, 1987-2003" em AAVV, Públicos da Cultura, Lisboa, Observatório das Actividades Culturais, pp. 241-283.

Throsby, David (2010), The Economics of Cultural Policy, Cambridge, Cambridge University Press.

Zimmer, Annette e Stefan Toepler (1999), "The subsidized muse: government and the arts in Western Europe and the United States", Journal of Cultural Economics, 23, pp. 33-49. 


\section{Legislação}

Portaria n.o 302/2017, de 16 de outubro (aprova o regulamento relativo à composição e funcionamento das comissões de apreciação e das comissões de avaliação, no âmbito do regime de atribuição de apoios financeiros do Estado às artes, aprovado pelo Decreto-Lei n.은 103/2017, de 24 de agosto).

Portaria n. 301/2017, de 16 de outubro (aprova o Regulamento dos Programas de Apoio às Artes, no âmbito do regime de atribuição de apoios financeiros do Estado às artes, aprovado pelo Decreto-Lei n.으 103/2017, de 24 de agosto).

Decreto-Lei n.o 103/2017, de 24 de agosto (aprova o regime de atribuição de apoios financeiros do Estado, através da DGArtes, a entidades que exerçam atividades profissionais nas áreas das artes visuais (arquitetura, artes plásticas, design, fotografia e novos media), das artes performativas (circo contemporâneo e artes de rua, dança, música e teatro) e de cruzamento disciplinar).

Decreto-Lei n. 114/2012, de 25 de maio (aprova a orgânica das Direções Regionais de Cultura).

Portaria n.o 58/2012, de 13 de março (aprova o Regulamento do Apoio à Internacionalização das Artes).

Decreto-Lei n. 196/2008, de 6 de outubro (procede à primeira alteração ao Decreto-Lei n.o 225/2006, de 13 de novembro, que estabelece o regime de atribuição de apoios financeiros do Estado, através do Ministério da Cultura, às artes).

Decreto-Lei n.o 91/2007, de 29 de março (aprova a orgânica da Direção-Geral das Artes).

Decreto-Lei n.o 225/2006, de 13 de novembro (estabelece o regime de atribuição de apoios financeiros do Estado, através do Ministério da Cultura, às artes).

Decreto-Lei n. 181/2003, de 16 de agosto (Lei Orgânica do Instituto das Artes).

Despacho Normativo n. 100/1990, de 14 de agosto (aprova as normas de apoio à atividade teatral). 


\section{ANEXOS}

Anexo 1. Pré-testes realizados

\begin{tabular}{lll}
\hline $\begin{array}{l}\text { Data de realiza- } \\
\text { ção }\end{array}$ & Área artística & Domínio de atividade \\
\hline 3-fev-2017 & Dança & Programação \\
3-fev-2017 & $\begin{array}{l}\text { Cruzamentos disciplina- } \\
\text { res }\end{array}$ & Criação \\
8-fev-2017 & Artes visuais & Programação \\
9-fev-2017 & Dança & Misto \\
9-fev-2017 & Teatro & Criação \\
9-fev-2017 & Dança & Misto \\
\hline
\end{tabular}




\section{Anexo 2. Questionário \\ ESTUDO POSICIONAMENTOS DAS ENTIDADES ARTÍSTICAS NO ÂM- BITO DA REVISÃO DO MODELO DE APOIO ÀS ARTES}

O presente estudo está a ser desenvolvido no Centro de Investigação e Estudos de Sociologia do Instituto Universitário de Lisboa (CIES-IUL/ISCTE-IUL) no âmbito do processo de revisão do modelo de apoio às artes da DGArtes.

Dirige-se às entidades, coletivas e singulares, que desenvolvem uma atividade profissional nas artes e que estão inscritas na plataforma da DGArtes de gestão dos apoios.

O questionário é composto por duas partes: uma de caracterização da entidade e outra de recolha de contributos sobre o modelo de apoio às artes.

O preenchimento pode ser feito em diversos momentos, revisto e alterado. As alterações feitas serão gravadas sempre que mudar de página. Para finalizar o preenchimento e submeter a resposta selecione "enviar questionário".

Pode descarregar o questionário aqui mas por favor tenha em conta que só serão consideradas válidas as respostas obtidas através da plataforma eletrónica.

O questionário estará ativo até ao dia 3 de março de 2017.

Toda a informação recolhida será tratada exclusivamente pela equipa do CIES-IUL que assegura a sua confidencialidade e garante o anonimato da informação a publicar com os resultados.

Para qualquer esclarecimento por favor não hesite em nos contactar utilizando o email estudoapoioartes.cies@iscte.pt.

Muito agradecemos a sua participação neste estudo, fundamental para um melhor conhecimento dos posicionamentos sobre o modelo de apoio às artes.

\section{A equipa}

José Soares Neves (coord.)

Joana Azevedo

Rui Telmo Gomes

Maria João Lima

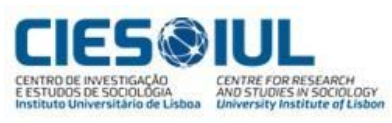


O questionário foi desenhado para poder abranger um conjunto diversificado de perfis. Nesse sentido, responda por favor às questões que considerar adequadas de acordo com o seu perfil. De modo a simplificar a formulação das questões, quer as entidades coletivas quer as singulares serão doravante designadas por "entidade".

\section{CARACTERIZAÇÃO DA ENTIDADE}

As perguntas deste grupo de caracterização são de resposta obrigatória, com exceção da Q1. (designação da entidade) que é facultativa.

Q1. Qual a designação da entidade?

\section{ESTATUTO JURÍDICO}

Q2. Do ponto de vista jurídico, a entidade é uma pessoa:
- Coletiva
- Singular

Q3. Qual a natureza jurídica da entidade?
- Associação
- Cooperativa
- Empresário em nome individual
- Estabelecimento em nome individual de responsabilidade limitada
- Fundação de direito privado
- Grupo informal
- Sociedade anónima
- Sociedade coligada
- Sociedade em comandita
- Sociedade em nome coletivo
- Sociedade por quotas
- Sociedade unipessoal
O Outra. Qual? 


\section{LOCALIZAÇÃO}

Q4. Qual a região da sede?

- Norte

- Centro

- Área Metropolitana de Lisboa

- Alentejo

- Algarve

○ Outra situação. Qual?

Q5. Qual o concelho da sede?

Q6. Qual o ano de fundação/início da atividade profissional da entidade?

Q6.1. Se a entidade presente sucede a outra, refira resumidamente esse historial no que diz respeito ao sistema de apoio às artes.

\section{ORÇAMENTO}

Q7. Indique por favor qual o valor do orçamento da entidade para o ano de 2016

(em Euros)

○ $\leq 5.000$

○ 5.001 a 10.000

○ 10.001 a 40.000

○ 40.001 a 100.000

○ 100.001 a 200.000

○ 200.001 a 300.000

○ $\quad 300.001$ a 500.000

- $\quad \geq 500.001$

- Sem orçamento para 2016

\section{TIPOLOGIA DE ATIVIDADE}

Q8. De acordo com o regulamento de apoio às artes, qual a tipologia de atividade da entidade?

(por favor assinale só uma opção) 


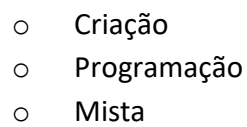

\section{ÁREA ARTÍSTICA}

Q9. Qual a área artística PRINCIPAL da entidade?

(por favor assinale só uma opção)
- Arquitetura
- Artes digitais
- Artes plásticas
- Dança
- Design
- Fotografia
- Música
- Teatro
- Cruzamentos disciplinares
- Outra área $=>$ Qual?

Q10. Qual (ou quais) a(s) área(s) artística(s) SECUNDÁRIA(S) da entidade? (pode assinalar mais do que uma opção)

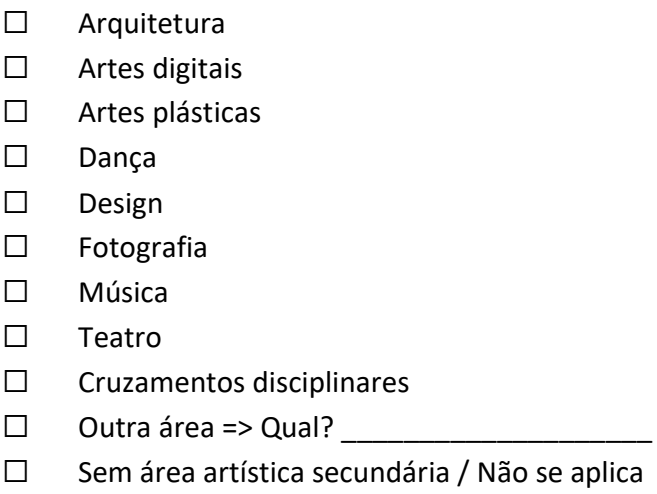




\section{CARACTERIZAÇÃO DE APOIOS}

Q11. A entidade alguma vez teve apoio financeiro por parte da DGArtes ou de entidades que lhe antecederam (como IPAE, IAC, IA)?

(assinale a opção que mais se adequa)

- Teve apoio (pelo menos uma vez)

- Concorreu mas nunca teve apoio

- Nunca concorreu

(Só para as entidades que assinalaram na Q11. "Teve apoio (pelo menos uma vez)")

Q11a. Ao abrigo do regime em vigor (desde 2006), qual a modalidade de que beneficiou?

(pode assinalar mais do que uma opção de resposta)

Não beneficiou após 2006

Apoio direto | quadrienal

Apoio direto | bienal

Apoio direto | anual

Apoio direto | pontual

Apoio indireto | acordos tripartidos

Apoio à internacionalização das artes

Apoio extraordinário

Outra.

Qual?

(só para as entidades que assinalaram na Q11a as modalidades "Apoio direto | quadrienal", Apoio direto | bienal" e "Apoio indireto | acordos tripartidos")

Q11b. No total, aproximadamente durante quantos anos a entidade beneficiou de apoio por parte da DGArtes ou de entidades que lhe antecederam (como IPAE, IAC, IA)? 
(só para as entidades que assinalaram na Q11. "Concorreu mas nunca teve apoio")

Q11c. Ao abrigo do regime em vigor (desde 2006), qual a modalidade a que se candidatou?

(pode assinalar mais do que uma opção de resposta)

$\square \quad$ Apoio direto | quadrienal

Apoio direto | bienal

Apoio direto | anual

Apoio direto | pontual

Apoio indireto | acordos tripartidos

Apoio à internacionalização das artes

Apoio extraordinário

Outra. Qual?

\section{(só para as entidades que assinalaram na Q11. "Nunca concorreu")}

Q11d. Identifique por favor os principais motivos para nunca ter concorrido aos apoios financeiros atribuídos pela DGArtes.

\section{CONTRIBUTOS SOBRE O MODELO DE APOIO ÀS ARTES}

Entramos agora no grupo de perguntas destinadas a recolher os contributos da entidade sobre o apoio às artes. Todas as perguntas são de resposta facultativa.

\section{MODALIDADES DE CONCURSO POR TIPOLOGIA DE ATIVIDADE (CRIA- ÇÃO/PROGRAMAÇÃO)}

Q12. Os apoios à criação e à programação têm sido maioritariamente atribuídos num mesmo concurso, sem distinção ou separação. Do ponto de vista da entidade, será de manter esta opção ou será de os separar em concursos diferentes (por exemplo, como no programa de apoios pontuais de 2016)? Por favor fundamente a resposta. 


\section{ÁREAS ARTÍSTICAS OBJETO DE APOIO}

Q13. No que diz respeito ao leque atual de áreas artísticas apoiadas pela DGArtes (Arquitetura, Design, Artes digitais, Artes plásticas, Fotografia, Música, Dança, Teatro, Cruzamentos Disciplinares), considera mais adequado:

Manter os apoios às atuais áreas artísticas.

Restringir as áreas artísticas apoiadas.

(Indique as áreas artísticas cujo apoio seria de manter)

Alargar os apoios a outras áreas artísticas.

(Identifique as outras áreas artísticas a apoiar)

Q13.1. Por favor fundamente a resposta.

\section{DESPESAS A CONSIDERAR NOS APOIOS}

Q14. Uma das questões que tem sido colocada refere-se ao tipo de despesas a considerar nos apoios, designadamente àquelas que se referem à estrutura organizacional.

Do ponto de vista da entidade, qual seria a forma mais adequada de distribuir o apoio financeiro entre as componentes referentes às atividades e à estrutura: Apenas para atividades? Atividades e estrutura, mas maioritariamente atividades? Atividades e estrutura de forma equilibrada? Atividades e estrutura, mas maioritariamente estrutura? Apenas para estrutura?

Por favor fundamente a resposta. 


\section{MECANISMOS DE ATRIBUIÇÃO DE APOIOS}

Q15. Para além dos apoios que já são atribuídos através de concurso público, considera relevante para o sector prever outros mecanismos de atribuição por parte da DGArtes?

Por favor fundamente a resposta.

\section{RELAÇÕES ENTRE A ENTIDADE E A DIREÇÃO-GERAL DAS ARTES}

Q16. Como descreve a relação entre a entidade e os serviços da DGArtes?

Q17. Como tem sido a resposta por parte dos serviços da DGArtes?

Q18. Como gostaria que, no futuro, os serviços da DGArtes se relacionem com a entidade?

\section{PROCESSO ADMINISTRATIVO}

Q19. O processo administrativo de candidatura ao apoio às artes tem sido feito através de uma plataforma eletrónica e solicitação de documentos vários.

Descreva a experiência da entidade e, caso tenha sugestões para o melhorar, queira fazer o favor de as enunciar.

\section{COMISSÕES DE APRECIAÇÃO}

Q20. Quais os aspetos mais relevantes para o funcionamento adequado das comissões de apreciação das candidaturas aos concursos de atribuição de apoios (júris)?

Por favor fundamente a resposta. 


\section{COMISSÕES DE ACOMPANHAMENTO E AVALIAÇÃO}

Q21. As entidades beneficiárias dos apoios plurianuais são objeto de avaliação pelas comissões de acompanhamento e avaliação.

Em que medida considera que são úteis para o desenvolvimento dos projetos apoiados?

\section{RELAÇõES ENTRE A ENTIDADE E AS DIREÇÕES REGIONAIS DE CULTURA (DRC)}

Q22. As DRC são intervenientes nos processos de apoio às artes geridos pela DGArtes, nomeadamente nas decisões sobre acordos tripartidos, apoio nas audiências de interessados e participação nas comissões de acompanhamento e avaliação.

Como descreve a relação da entidade com as DRC?

Q23. Como tem sido a resposta por parte das DRC?

Q24. Como gostaria que, no futuro, venha a ser o papel das DRCs nos processos de apoio às artes?

\section{ARTICULAÇÃO ENTRE ADMINISTRAÇÃO CENTRAL E LOCAL NO QUADRO DO APOIO ÀS ARTES}

Q25. A administração local desempenha uma função crescentemente importante no campo das artes. Pode descrever como tem sido a relação da entidade com a administração local no quadro dos apoios às artes atribuídos pela DGArtes?

Q26. No futuro, que papel poderá ser desempenhado pela administração local no modelo de apoio às artes? 
Q27. A articulação das entidades artísticas com a administração central e local é atualmente objeto de uma modalidade específica de apoio às artes já referida (acordos tripartidos).

Caso a entidade tenha experiência de trabalho direta ou indireta com este tipo de apoio, por favor descreva-a, incluindo eventuais sugestões de alteração que julgue relevantes.

\section{REDES DE PROGRAMAÇÃO}

Q28. Em que medida o modelo de apoio às artes deve contemplar a articulação com redes de programação?

Por favor fundamente a resposta.

\section{INTERNACIONALIZAÇÃO}

Q29. Considerando a experiência da entidade, que projetos de internacionalização deverão ser contemplados pelos apoios da DGArtes?

(assinale as opções que mais se adequam)

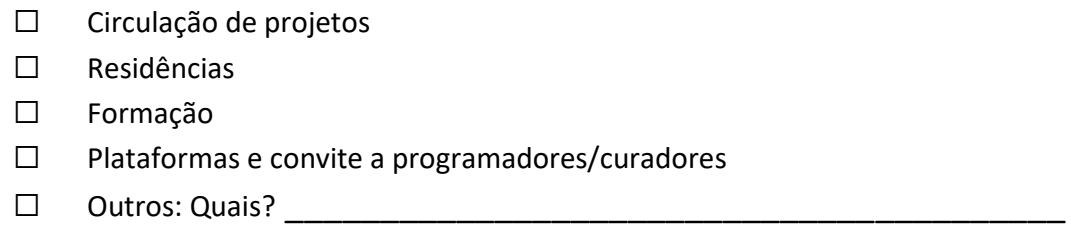

Q29.1 Por favor fundamente a resposta

Q30. Ainda considerando a experiência da entidade, qual deve ser o posicionamento da DGArtes no caso específico dos projetos internacionais em rede? Se considerar relevante especifique que atividades deverão ser apoiadas. 


\section{PÚBLICOS}

Q31. A diversidade dos públicos (como os públicos adultos, os públicos infanto-juvenis e as comunidades locais) vêm ganhando uma relevância crescente.

De que modo estas vertentes devem ser valorizadas no modelo de apoio às artes?

Por favor fundamente a resposta.

Q32.No modelo de apoio às artes, a vertente dos públicos deve ser considerada como:

(assinale as opções que mais se adequam)

$\square$ Modalidade de apoio.

$\square$ Fator de majoração em candidatura.

$\square$ Critério de avaliação.

$\square$ Não deve ser considerada.

$\square$ Outra solução. Qual?

Q32.1. Por favor fundamente a resposta.

\section{CONDIÇÕES LABORAIS}

Q33. As questões da precariedade vêm ganhando maior eco nas políticas públicas. De acordo com a experiência da entidade, que mecanismos poderiam ser criados para assegurar soluções adequadas no quadro dos apoios às artes?

\section{INICIATIVAS DE APOIO INTERMINISTERIAIS}

Q34. Como encara soluções de apoios que envolvam diferentes sectores interministeriais (por exemplo, cultura e educação, cultura e ciência \& tecnologia, cultura e ambiente, cultura e economia)?

Q35. Em que medida o apoio às artes deve ter em conta outro tipo de critérios de apreciação das propostas que não apenas os estritamente artísticos (por 
exemplo, inclusão social, interculturalidade, acessibilidade, turismo, inovação, criação de emprego, ou outros)?

Por favor fundamente a resposta.

REGULAMENTO VIGENTE DE APOIO ÀS ARTES: ASPETOS POSITIVOS E NEGATIVOS

Q36. A partir da experiência da entidade, por favor identifique os aspetos positivos e negativos mais relevantes no atual modelo de apoio.

Q36.1. Aspetos positivos

Q36.2. Aspetos negativos

\section{OUTROS ASPETOS}

Q37. O questionário está a terminar.

Queira por favor acrescentar algum aspeto sobre o apoio às artes que não tenha sido antes abordado.

O questionário chegou ao fim.

Para submeter a resposta basta selecionar "enviar questionário".

Muito obrigado pela colaboração! 


\section{Anexo 3. Modelo de e-mail: convite à participação}

De: EstudoApoioArtes.Cies@iscte.pt

Para: [e-mail entidade]

Assunto: Convite à participação || ESTUDO POSICIONAMENTOS DAS ENTIDADES ARTÍSTICAS NO ÂMBITO DA REVISÃO DO MODELO DE APOIO ÀS ARTES

[nome da entidade]

Exm@s.Sr@s.

Na sequência das políticas definidas pelo atual governo para o sector da Cultura, está em curso um processo de revisão do modelo de apoio às artes que se pretende participado e no qual se procura auscultar as entidades, coletivas e singulares, que desenvolvem uma atividade profissional nas artes.

Neste âmbito, o Centro de Investigação e Estudos de Sociologia do Instituto Universitário de Lisboa (CIES-IUL/ISCTE-IUL) foi convidado para desenvolver o presente Estudo que se dirige às referidas entidades que estão registadas na plataforma de gestão dos apoios da DGArtes.

O questionário estará aberto até ao próximo dia 3 de março.

Toda a informação recolhida será tratada exclusivamente pela equipa do CIESIUL que assegura a sua confidencialidade e garante o anonimato da informação a publicar com os resultados.

Para qualquer esclarecimento por favor utilize o e-mail estudoapoioartes.cies@iscte.pt

Agradecemos a sua participação no Estudo, fundamental para um melhor conhecimento dos posicionamentos das entidades artísticas sobre o modelo de apoio às artes.

O questionário do Estudo está disponível para preenchimento online.

Para aceder por favor siga a ligação eletrónica abaixo.

EstudoApoioArtes Questionário

\section{A Equipa}

José Soares Neves (coord.)

Joana Azevedo

Rui Telmo Gomes

Maria João Lima 
O presente e-mail é enviado a todas as entidades registadas na plataforma eletrónica da DGArtes. Se está registado(a), mas não se enquadra no universo de estudo, por favor comunique-nos essa informação respondendo a esta mensagem.

Seguir a ligação para anular a subscrição de futuros e-mails.

Clique aqui para anular 


\section{Anexo 4. Modelo de e-mail: lembrete}

De: EstudoApoioArtes.Cies@iscte.pt

Para: [entidades que ainda não completaram preenchimento]

Assunto: E-mail convite devolvido || ESTUDO POSICIONAMENTOS DAS ENTIDADES ARTÍSTICAS NO ÂMBITO DA REVISÃO DO MODELO DE APOIO ÀS ARTES

[nome da entidade]

Exm@s Senhor@s,

O questionário do Estudo Posicionamentos das Entidades Artísticas no Âmbito da Revisão do Modelo de Apoio às Artes encerra no próximo dia 3 de março de 2017.

Se ainda não iniciou e pretende participar neste estudo por favor responda quanto antes.

Se já fez o preenchimento, mas não carregou no botão "enviar questionário" por favor faça-o para finalizar o questionário.

Em qualquer dos casos, pode aceder ao seu questionário seguindo a ligação abaixo.

EstudoApoioArtes Questionário

Se, entretanto, já respondeu ao questionário, por favor ignore esta mensagem. Muito obrigado pela sua participação e pela sua colaboração.

Com os nossos melhores cumprimentos,

\section{A equipa do CIES-IUL}

José Soares Neves (coord.)

Joana Azevedo

Rui Telmo Gomes

Maria João Lima

O presente e-mail é enviado a todas as entidades registadas na plataforma eletrónica da DGArtes. Se está registado(a), mas não se enquadra no universo de estudo, por favor comunique-nos essa informação respondendo a esta mensagem.

Seguir a ligação para anular a subscrição de futuros e-mails.

Clique aqui para anular 
Anexo 5. Taxa de resposta às perguntas abertas (parte ii-contributos)

\begin{tabular}{l|c}
\hline \multicolumn{1}{c|}{ Questão } & $\%$ \\
\hline Q12. Modalidades de Concurso (Criação/Programação) & 88,2 \\
Q13. Áreas artísticas objeto de apoio & $\underline{97,5}$ \\
Q14. Despesas a considerar dos apoios (Estrutura/Atividades) & 90,6 \\
Q15. Mecanismos de atribuição de apoios & 85,2 \\
Q16. Relação com serviços da DGArtes & 88,5 \\
Q17. Resposta por parte dos serviços da DGArtes & 82,0 \\
Q18. Futuro relacionamento com serviços da DGArtes & 86,0 \\
Q19. Processo Administrativo & 84,7 \\
Q20. Comissões de Apreciação & 82,0 \\
Q21. Comissões de Acompanhamento e Avaliação & 77,4 \\
Q22. Relação com DRC & 70,9 \\
Q23. Resposta DRC & 61,7 \\
Q24. Futuro relação com DRC & 69,9 \\
Q25. Papel atual da Adm. Local no apoio às artes & 70,7 \\
Q26. Papel futuro da Adm. Local no apoio às artes & 69,2 \\
Q27. Acordos tripartidos & 46,2 \\
Q28. Redes de programação & 69,9 \\
Q29. Apoio à Internacionalização de projetos & 90,6 \\
Q30. Projetos internacionais em rede & 56,5 \\
Q31. Públicos & 77,4 \\
Q32. Vertente de públicos no MAA & 91,4 \\
Q33. Condições Laborais (Precariedade) & 73,9 \\
Q34. Apoios interministeriais & 78,5 \\
Q35. Outros critérios de apreciação & 78,7 \\
Q36. Aspetos positivos e negativos do atual MAA & 71,3 \\
Q37. Outros assuntos & 42,7 \\
\hline Bas. 522 respostas vardas. &
\end{tabular}


Anexo 6. Intervenção do secretário de Estado da Cultura, Miguel Honrado, nas sessões regionais de apresentação da proposta de modelo de apoio às artes

\section{PROCESSO DE CRIAÇÃO DO NOVO MODELO DE APOIO ÀS ARTES}

NOS DIAS 11, 12 E 13 JULHO DE 2017, NAS CIDADES DE FARO, ÉVORA, COIMBRA E PORTO, FOI APRESENTADA A PROPOSTA DE MODELO DE APOIO ÀS ARTES, CRIADA PELO GOVERNO APÓS AUSCULTAÇÃO ÀS ENTIDADES CULTURAIS DO PAÍS.

\section{INTERVENÇÃO DO SECRETÁRIO DE ESTADO DA CULTURA, MIGUEL HONRADO}

Boa tarde,

Gostaria de Vos agradecer as questões levantadas, que nos permitiram refletir e clarificar diversas perspetivas, todas relevantes para a proposta do novo modelo de apoio às artes e para os passos que se seguem.

Mais uma vez pudemos assistir à Vossa capacidade de reflexão e de exposição. É precisamente isso que pretendemos continuar a fazer nos próximos anos: queremos trabalhar direta e diariamente convosco. Sem esta proximidade, abertura e frontalidade, qualquer relação entre poder governativo e agentes culturais será frágil.

O Vosso envolvimento nos processos de reflexão é naturalmente imprescindível para a nossa tomada de decisão responsável e para o rumo que todos pretendemos seguir na gestão das artes e do país.

O debate foi muito rico e todas as questões foram registadas e serão certamente analisadas.

Este modelo é novo, demorou muitos meses a ser construído, teve inúmeras fases, todas de intenso e sério trabalho, nosso e de muitas pessoas que integrámos em momentos cruciais. Acreditamos que um período de leitura e de análise para uma total integração e apropriação das suas potencialidades é fundamental. O desafio e o exercício que Vos lançamos é precisamente esse, que o analisem e o testem; não apenas para o Vosso caso em concreto, mas para os de outros, de natureza, objetos e missões distintos.

Nesta fase do processo de revisão do Modelo de Apoio às Artes, entender e incorporar esta nova ferramenta, por um lado, e percecionar a sua capacidade de resposta aos desafios do sector, por outro, será essencial para a finalização deste diploma e sobretudo para a sua futura utilização. 
Este modelo tem de ser capaz de dar resposta à grande variedade e heterogeneidade do sector. As entidades criadoras de cultura devem encontrar no Modelo de Apoio às Artes uma forma de identificação e de articulação que contribua para o cumprimento da sua missão de serviço público. Sejam estruturas de programação que existem há muitos anos, sejam novos criadores, sejam projetos de longo ou de curto prazo, seja nos grandes centros urbanos ou fora deles, individualmente, em coprodução, em parceria ou em rede, em território nacional e internacional, as entidades devem encontrar uma oportunidade de aceder aos apoios públicos para as artes. Este é o nosso objetivo.

Sejamos, porém, face a este objetivo, o mais focados e pragmáticos possível. O tempo é curto e uma mudança exige sempre uma fase de adaptação. No decorrer deste processo, devemos focar-nos no essencial, que é, em nosso entender, criar um diploma consistente e abrangente, que seja o pilar dos apoios às artes e, simultaneamente, continuar a colaborar nas ferramentas e nas condições que operacionalizam o modelo, e em outras medidas que sustentam o crescimento consolidado das artes em Portugal.

Como percebemos, o modelo é orgânico e flexível e o diploma determinará o essencial, é a pedra basilar de um sistema maior. Este modelo que propomos tem, depois do diploma consolidado, a fase de operacionalização que se consubstancia nos avisos de abertura a concursos e nos procedimentos de candidatura.

Esta é uma das suas enormes vantagens: as questões aqui levantadas, bem como todas aquelas que venham a surgir no decorrer da aplicação continuada da lei, podem ser respondidas e integradas de forma mais orgânica. $O$ decreto -lei determina os princípios da política de apoios para as artes, e este instrumento deve ser estável e durável. Mas a sua flexibilidade e modularidade permitem que, em sede de regulamento e avisos de abertura, seja adaptável às novas dinâmicas e integre necessidades emergentes; no fundo, capacita o modelo a ser um instrumento sempre atual.

$\mathrm{O}$ anterior modelo era muitíssimo rígido e determinista. A lei impunha uma gestão de carácter estanque e repetitivo: quer nas características dos concursos, quer nas candidaturas, quer na distribuição geográfica, quer nas áreas e disciplinas artísticas, quer inclusive na avaliação ou no acompanhamento, todos os concursos e avisos simplesmente se replicavam há anos, muitas vezes desfasados das reais carências e dos objetivos dos agentes e do país. Este comportamento ensimesmado falha rotundamente à partida a sua relação de escuta e permanente análise da realidade: o sector, as entidades, os projetos são muito 
distintos entre si e trazem desafios e necessidades bem diversos, que carecem de respostas ajustadas.

As componentes que estruturam o sistema do apoio às artes - entidades, disciplinas artísticas, domínio de atividade, territórios, públicos, e a forma como se relacionam entre si a cada momento - estão em permanente evolução; não era, portanto, possível manter um sistema de arquitetura estática e tipificada.

Pretendemos de facto simplificar e personalizar: simplificar procedimentos e personalizar a atuação. Compete ao governo criar soluções ágeis, capazes de garantir níveis de resposta eficazes, que permitam às entidades fazer o seu trabalho: gerir, criar, programar e alcançar os seus públicos. Este instrumento é, em suma, uma solução de gestão cultural, criado para as entidades poderem tirar dele o maior partido e o usarem nas suas múltiplas configurações.

É necessário confiar na capacidade de gestão e de visão de cada entidade e conferir independência e autonomia ao processo de evolução de cada uma em particular. Não pretendemos soluções puramente burocratizadas ou administrativas de réplica ou replicação. Teria sido mais fácil e mais rápido criar um modelo mais ou menos decalcado do anterior, mas não era esse o trilho que as artes e as políticas públicas dos apoios às artes precisavam.

A proposta do novo Modelo de Apoio às Artes vive de uma arquitetura simplificada e de linhas muito claras. No entanto é flexível, inclusiva e agregadora a todos os níveis.

Introduz processos simplificados. Abre-se a novas áreas artísticas. Alarga e reestrutura domínios de atividade. Prevê a interpermutabilidade dos domínios de atividade. Promove e valoriza relações entre sectores, entidades e territórios. Prevê o alargamento territorial nacional. Estimula estratégias de desenvolvimento local, individuais e em rede. Valoriza despesas e encargos de estrutura como condição para a sustentação de uma atividade continuada. Inclui financiamento a acolhimento de agentes. Apoia a circulação internacional. Apoia contrapartidas nacionais a projetos com fundos internacionais. Estimula a captação de linhas de apoios e outras formas de investimento. Incrementa estratégias de acompanhamento e agrega mais informação na avaliação. Valoriza boas práticas de gestão e de contratação.

A par destas incorporações, o Modelo de Apoio às Artes mantém a aposta estratégica nos apoios plurianuais - que agora designamos por apoios sustentados - e a projetos de desenvolvimento, criação e inovação artística - os antigos pontuais, que agora designamos por apoio a projetos. Continuaremos a ter estes dois tipos de apoio - sustentados e projetos - como eixos estruturantes do apoio às artes, mas agora com um âmbito muito mais alargado. 
Quase a terminar a minha intervenção, gostaria de partilhar convosco que os tempos previstos para o circuito legislativo são curtos, no que concerne ao normal funcionamento do Estado. É fundamental que as sugestões ao diploma que possam ter nos cheguem com rapidez e de forma objetiva, para que seja viável a sua leitura, interpretação e, sendo possível, a sua integração ao diploma.

Por fim, resta-me agradecer mais uma vez a Vossa participação em todo este processo. $\mathrm{O}$ maior ativo deste trabalho de revisão do Modelo de Apoio às Artes é, sem sombra de dúvida, a reflexão que lhe deu origem e que certamente continuará como sedimento do trabalho futuro. A disponibilidade, a responsabilidade e o empenho que as entidades têm dedicado a este processo é, considero, um exemplo de maturidade do nosso setor e uma demonstração evidente do exercício democrático na construção de políticas culturais para o nosso país. Obrigado! 


\section{NOTAS BIOGRÁFICAS}

José Soares Neves é doutorado em Sociologia da Comunicação, da Cultura e da Educação pelo ISCTE - Instituto Universitário de Lisboa. É investigador integrado no Centro de Investigação e Estudos de Sociologia do Instituto Universitário de Lisboa (CIES-IUL) e professor auxiliar convidado no Departamento de Sociologia do ISCTE - Instituto Universitário de Lisboa. Foi investigador e coordenador de projetos do Observatório das Atividades Culturais (OAC) durante a sua existência (1996 a 2013) e presidente do Grupo de Trabalho sobre Estatísticas da Cultura do Conselho Superior de Estatística (2006 a 2010). Participou em diversos projetos de investigação nos campos da sociologia da cultura e das políticas culturais e nos domínios das indústrias culturais (música e livro), da leitura e dos museus.

Joana Azevedo é doutorada em Teoria e Investigação Social pela Università degli Studi di Roma "La Sapienza", pós-graduada em Análise de Dados em Ciências Sociais e licenciada em Sociologia pelo ISCTE-IUL. É professora auxiliar convidada no Departamento de Sociologia do Instituto Universitário de Lisboa (ISCTE-IUL), onde leciona na área da cultura e ciências da comunicação. É investigadora integrada no Centro de Investigação e Estudos de Sociologia (CIES-IUL). Integra ainda a equipa de investigação do Observatório da Comunicação (Obercom).

Rui Telmo Gomes é doutorado em Sociologia pelo ISCTE - Instituto Universitário de Lisboa e investigador no Centro de Investigação e Estudos de Sociologia (CIES-IUL). Integrou a equipa de investigação e direção do Observatório das Atividades Culturais. Neste quadro realizou investigação aplicada sobre políticas culturais e avaliação de programas e projetos culturais. Foi diretor da revista do Observatório, OBS. Recentemente tem desenvolvido e participado em diferentes projetos de investigação nos domínios da sociologia da cultura e das culturas juvenis, privilegiando temas como: arte comunitária e associativismo juvenil; cenas musicais underground; novas profissões artísticas e no sector criativo. 
Maria João Lima é doutoranda em Sociologia pelo ISCTE-IUL e bolseira de Doutoramento da Fundação para a Ciência e a Tecnologia (FCT) no Centro de Investigação e Estudos de Sociologia do Instituto Universitário de Lisboa (CIES-IUL). É mestre em Etnomusicologia e licenciada em Ciências Musicais pela Faculdade de Ciências Sociais e Humanas da Universidade Nova de Lisboa (FCSH-UNL). Foi investigadora do INET-MD - Instituto de Etnomusicologia Música e Dança (1995-2000) e do OAC - Observatório das Atividades Culturais (2001-2013), tendo colaborado em diversas pesquisas e publicações sobre a avaliação de políticas culturais locais e nacionais, públicos da cultura, práticas culturais, entre outros. 

O financiamento às artes constitui uma vertente fundamental das políticas públicas de democratização e descentralização da oferta cultural e é uma componente central na vitalização das entidades artísticas profissionais do terceiro sector. A participação dos agentes artísticos na definição das orientações que mais diretamente os afetam é uma das vias suscetíveis de contribuir para a qualificação da democracia, das políticas e dos serviços prestados.

Que posicionamentos se podem identificar sobre o modelo de apoio às artes em Portugal? É a esta pergunta que o presente Estudo Posicionamentos das Entidades Artísticas no Âmbito da Revisão do Modelo de Apoio às Artes procura responder. $O$ estudo insere-se num processo de auscultação das entidades artísticas do sector promovido pela DGArtes e pela tutela no âmbito da redefinição prevista no programa do XXI Governo Constitucional.

0 estudo decorreu entre janeiro e junho de 2017 e foi realizado por uma equipa do CIES-IUL. De acordo com o objetivo traçado pela DGArtes e pela tutela - realizar uma auscultação das entidades do sector o mais alargada possível - adotou-se uma estratégia metodológica de inquérito extensivo, por questionário online ao universo constituído pelas entidades coletivas ou singulares do terceiro sector, registadas na DGArtes, que desenvolvem uma atividade profissional nas áreas das artes.

Nesta obra apresentam-se em detalhe os resultados deste processo de auscultação que contou com uma ampla participação do sector e com os contributos qualitativos de mais de quinhentas entidades de diferentes áreas artísticas, regiões do país e experiências de relação com o modelo de apoio às artes (apoiadas e não apoiadas).

O estudo permite caracterizar a diversidade de posicionamentos face a um conjunto alargado de dimensões da relação das entidades com o modelo, identificando as questões essenciais em debate no sector que permitem traçar linhas de trabalho futuras face às políticas e ao apoio às artes em Portugal.

Autoria:

José Soares Neves (Coord.) (ISCTE-IUL, CIES-IUL)

Joana Azevedo (ISCTE-IUL, CIES-IUL)

Rui Telmo Gomes (ISCTE-IUL, CIES-IUL)

Maria João Lima (ISCTE-IUL, CIES-IUL)

Enquadramento institucional:

Instituto Universitário de Lisboa (ISCTE-IUL)

Centro de Investigação e Estudos de Sociologia (CIES-IUL). 